\title{
Small Business Demand Response with Communicating Thermostats: SMUD's Summer Solutions Research Pilot
}

\author{
Karen Herter, Seth Wayland, Josh Rasin \\ Heschong Mahone Group
}

September 2009 


\section{Disclaimer}

This document was prepared as an account of work sponsored by the United States Government. While this document is believed to contain correct information, neither the United States Government nor any agency thereof, nor The Regents of the University of California, nor any of their employees, makes any warranty, express or implied, or assumes any legal responsibility for the accuracy, completeness, or usefulness of any information, apparatus, product, or process disclosed, or represents that its use would not infringe privately owned rights. Reference herein to any specific commercial product, process, or service by its trade name, trademark, manufacturer, or otherwise, does not necessarily constitute or imply its endorsement, recommendation, or favoring by the United States Government or any agency thereof, or The Regents of the University of California. The views and opinions of authors expressed herein do not necessarily state or reflect those of the United States Government or any agency thereof or The Regents of the University of California. 


\section{Acknowledgements}

The work described in this report was coordinated by the Demand Response Research Center and funded by the California Energy Commission (Energy Commission), Public Interest Energy Research (PIER) Program, under Work for Others Contract No. 500-03-026 and by the U.S. Department of Energy under Contract No. DE-AC02-05CH11231.

Thanks to all the folks at SMUD that made this research possible, in particular Vikki Wood, Ralph Carlson, Amy Furlong, and the metering and billing teams. Thanks also to Roger Levy, Rick Diamond, and Mary Ann Piette at the DRRC for guidance and support throughout.

Also, special thanks to our technology collaborators: Mike Kuhlman and Chris Aughinbaugh at Residential Control Systems, Inc., provider of the communicating thermostats; and Rick Boland and Jackson Wang at eRadio, provider of the RDS event signaling system.

Please cite this report as:

Herter, Karen, Seth Wayland, Josh Rasin. 2009. Small Business Demand Response with Communicating Thermostats: SMUD's Summer Solutions Research Pilot. Heschong Mahone Group for the California Energy Commission, PIER Building End-Use Energy Efficiency Program. 


\section{Table of Contents}

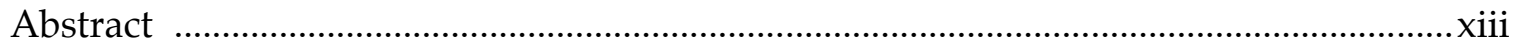

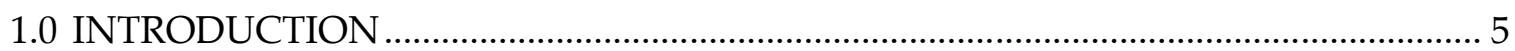

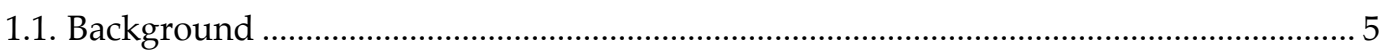

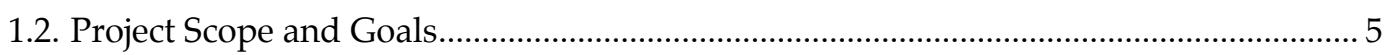

1.3. Project Overview and Schedule …………………...................................................... 6

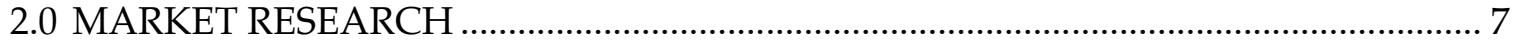

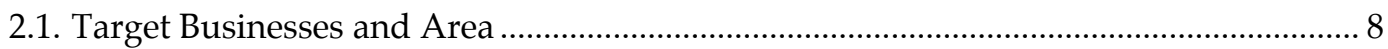

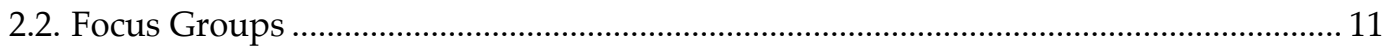

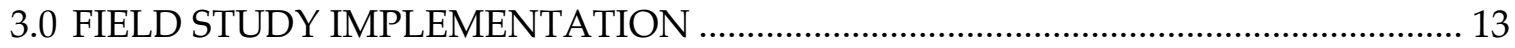

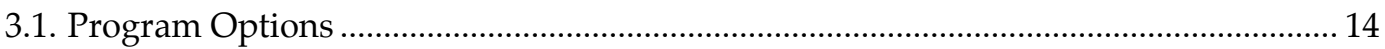

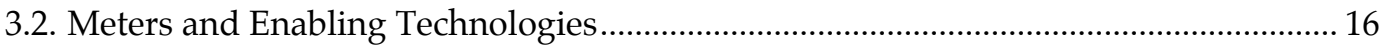

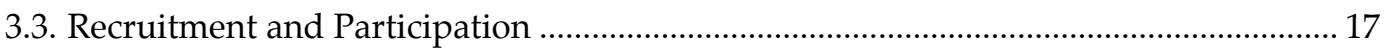

3.4. Participant Preparation and Education ...................................................................... 21

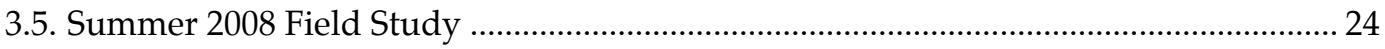

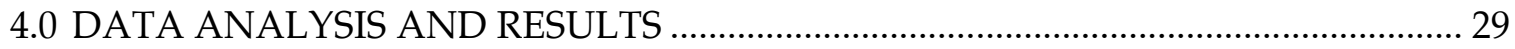

4.1. Thermostat Logger Data.............................................................................................. 30

4.2. Hourly Load Impacts on Event Days ……………........................................................ 36

4.3. Energy Impacts: Summer 2007 vs. Summer 2008 ........................................................ 50

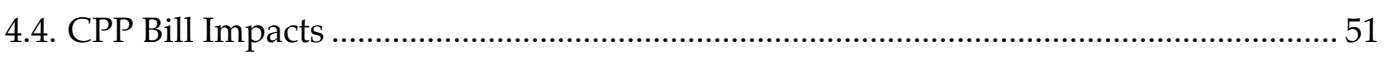

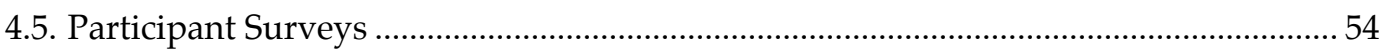

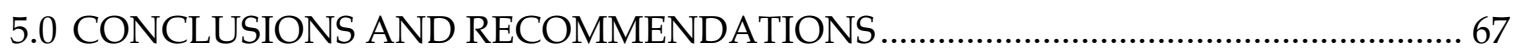

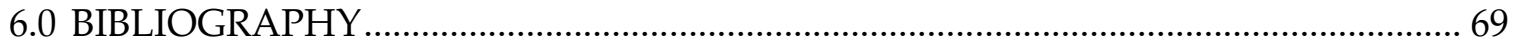

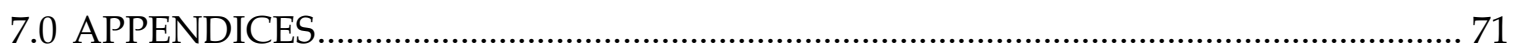

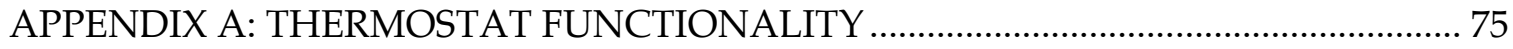

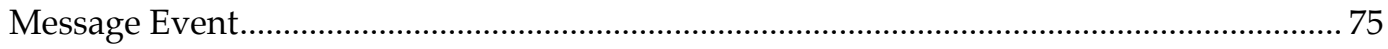

Price Event ............................................................................................................................. 77

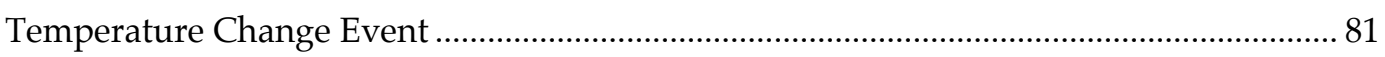

APPENDIX B: SURVEY QUESTIONS AND SUMMARY OF ANSWERS ........................ 87

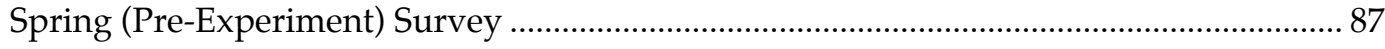

Summer (Post-Event) Surveys .............................................................................................. 114

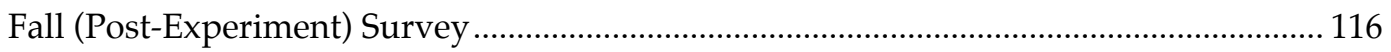




\section{List of Figures}

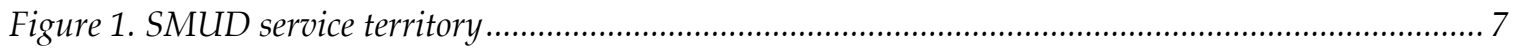

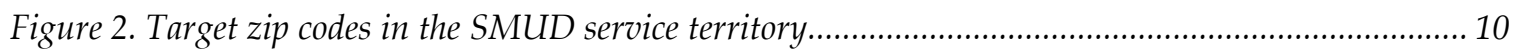

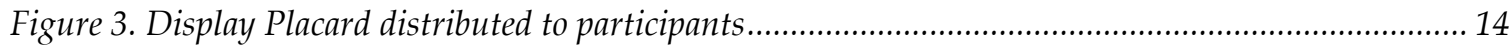

Figure 4. Residential Control System's TR40 Display Unit ............................................................... 17

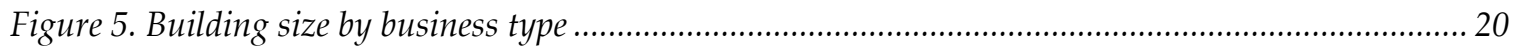

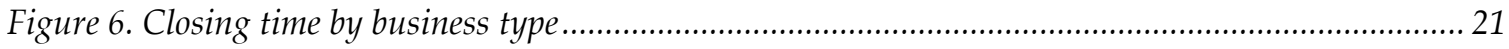

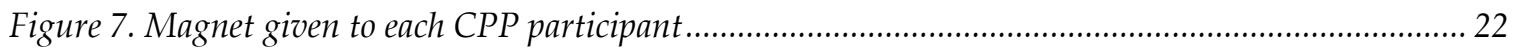

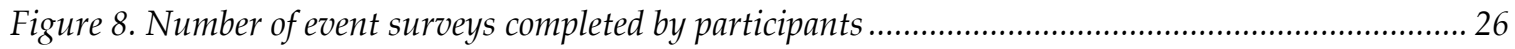

Figure 9. Percentage of event signals received and acted upon, by event number ....................................... 30

Figure 10. Percentage of thermostats receiving no events signals, all 12 event signals, and everything in between 31

Figure 11. Event and non-event setpoints, with weather-normalized compressor status, offices................. 33

Figure 12. Event and non-event setpoints, with weather-normalized compressor status, restaurants........ 34

Figure 13. Event and non-event setpoints, with weather-normalized compressor status, retail................. 35

Figure 14. Temperature profile used to create load and impact results.................................................... 37

Figure 15. Total Load Change on event days, percent vs. watts ............................................................. 38

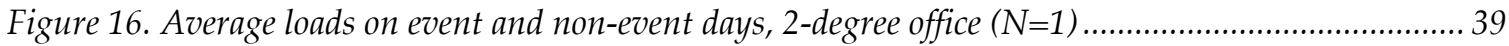

Figure 17. Average loads on event and non-event days, 4-degree office $(N=11)$....................................... 40

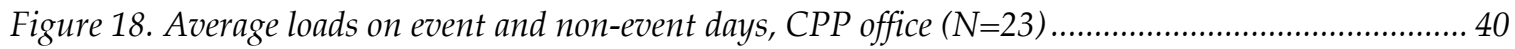

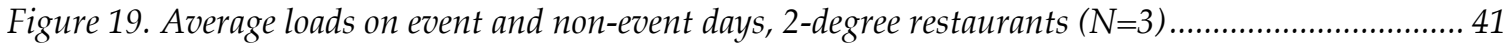

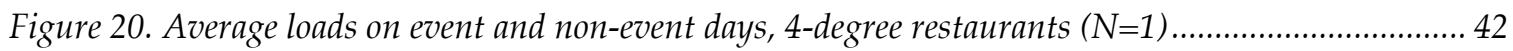

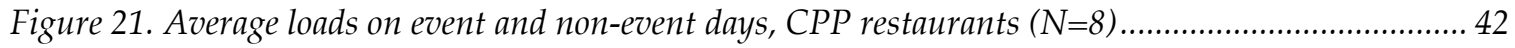

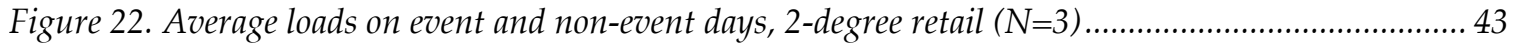

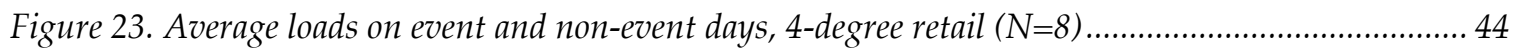

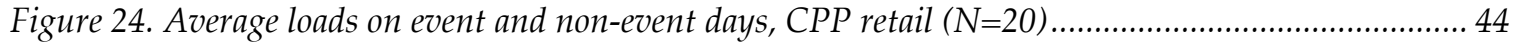

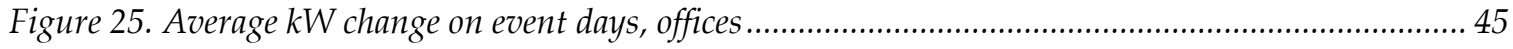

Figure 26. Average precool, event and rebound impacts on event days, offices .......................................... 46

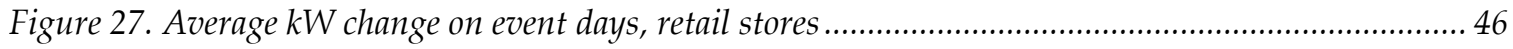

Figure 28. Average precool, event and rebound impacts on event days, retail .......................................... 47

Figure 29. Average $k W$ change on event days, 4-degree ACC ................................................................ 47

Figure 30. Average precool, event and rebound impacts on event days, $4^{\circ}$ ACC ..................................... 48

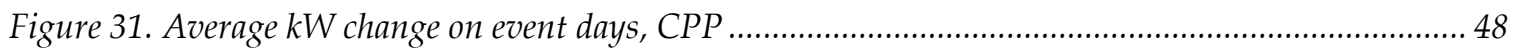

Figure 32. Average precool, event and rebound impacts on event days, CPP .......................................... 49

Figure 33. Dollars vs. percent bill change, CPP participants ................................................................... 52

Figure 34. Summer bill savings vs. load change for event period ............................................................. 53

Figure 35. Summer bill savings vs. load change for entire event day ....................................................... 54

Figure 36. Load shifting and conservation actions before and during the pilot ........................................... 55 
Figure 37. Load shifting and conservation actions during the pilot, by business ....................................... 56

Figure 38. Load shifting and conservation actions during the pilot, by program ...................................... 56

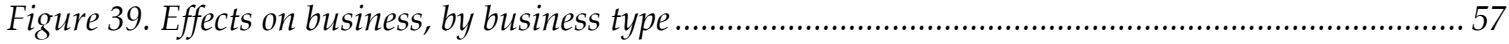

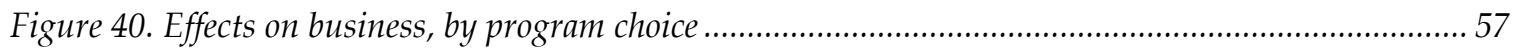

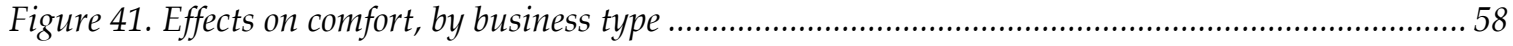

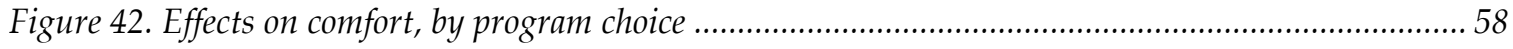

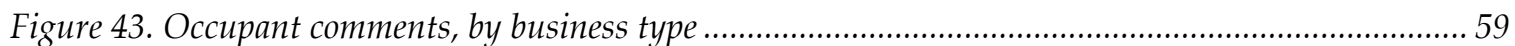

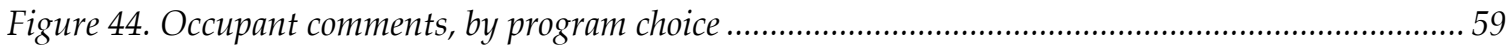

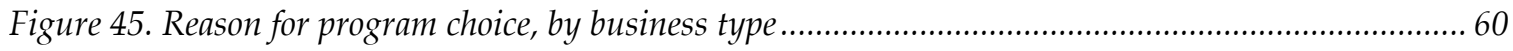

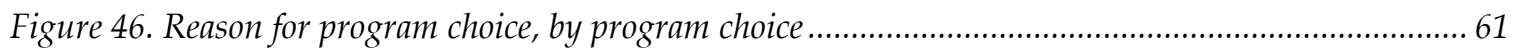

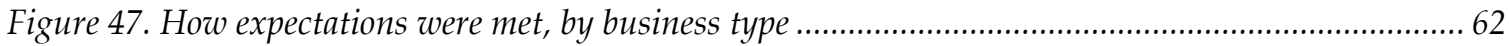

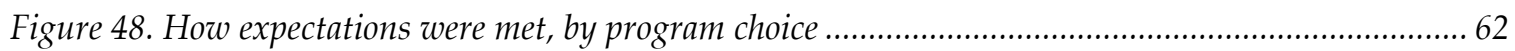

Figure 49. Willingness to participate without participation incentive, by business type............................ 63

Figure 50. Willingness to participate without participation incentive, by program choice.......................... 63

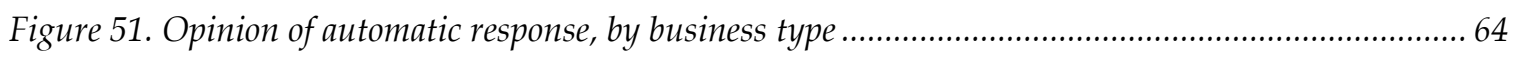

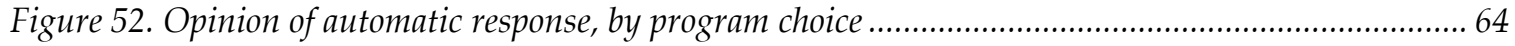

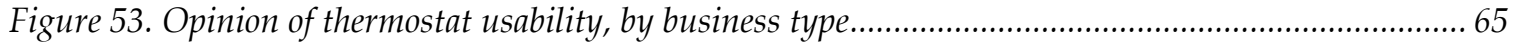

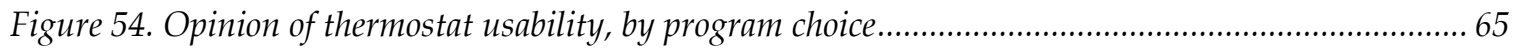

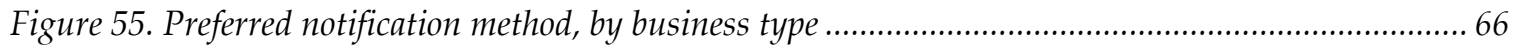

Figure 56. Preferred notification method, by program choice .................................................................. 66

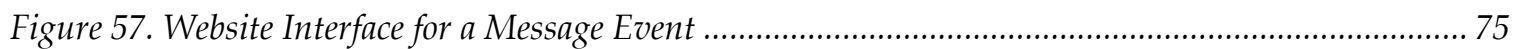

Figure 58. Programmable Communicating Thermostat Displaying a Message ........................................ 76

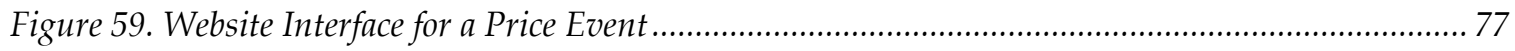

Figure 60. Programmable Communicating Thermostat Displaying Tier 4 Notice .................................... 78

Figure 61. Programmable Communicating Thermostat Showing Current Settings Before Tier 4 Event.... 78

Figure 62. Programmable Communicating Thermostat Displaying Tier 4 Event in Progress................... 79

Figure 63. Programmable Communicating Thermostat Showing Current Settings During a Tier 4 Price Event 79

Figure 64. Programmable Communicating Thermostat Displaying End of Price Event Message .............. 80

Figure 65. Website Interface for a Temperature Change Event .............................................................. 81

Figure 66. Programmable Communicating Thermostat Displaying Temperature Change Notice ............... 82

Figure 67. Programmable Communicating Thermostat Displaying Current Settings Before Temperature Event 82

Figure 68. Programmable Communicating Thermostat Displaying Ttemperature Event in Progress Notice83 Figure 69. Programmable Communicating Thermostat Displaying Current Settings During Temperature Event 83

Figure 70. Programmable Communicating Thermostat Displaying End of Temperature Event Notice ..... 84 


\section{List of Tables}

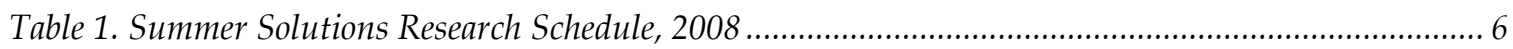

Table 2. Small commercial customer characteristics by building type, July 2007 ........................................ 8

Table 3. Number of businesses in the target area, by zip code ..................................................................... 11

Table 4. CPP tariff compared to the standard small commercial rate ...................................................... 15

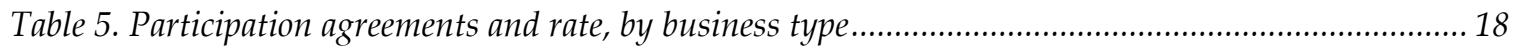

Table 6. Participant program choices (including PCTs) by business type................................................. 19

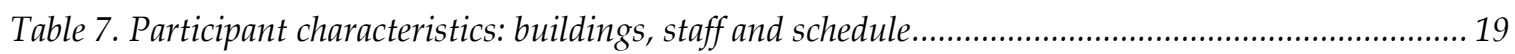

Table 8. Schedule of events for the 2008 Summer Solutions Pilot ............................................................ 24

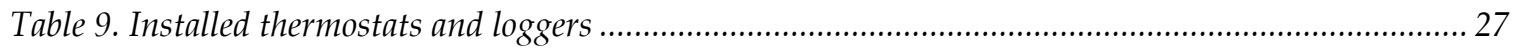

Table 10. Summary of data collected for this project ................................................................................. 29

Table 11. Percent of event signals overridden, by business type and program choice ................................ 31

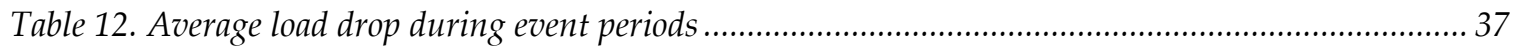

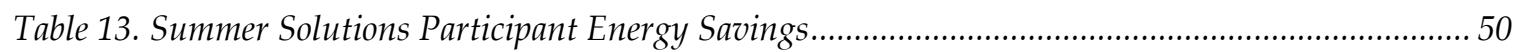

Table 14. Summary of bill effects for CPP participants ...................................................................... 51 


\section{Abstract}

This report documents a field study of 78 small commercial customers in the Sacramento Municipal Utility District service territory who volunteered for an integrated energy-efficiency/ demand-response (EE-DR) program in the summer of 2008. The original objective for the pilot was to provide a better understanding of demand response issues in the small commercial sector. Early findings justified a focus on offering small businesses (1) help with the energy efficiency of their buildings in exchange for occasional load shed, and (2) a portfolio of options to meet the needs of a diverse customer sector. To meet these expressed needs, the research pilot provided on-site energy efficiency advice and offered participants several program options, including the choice of either a dynamic rate or monthly payment for air-conditioning setpoint control.

An analysis of hourly load data indicates that the offices and retail stores in our sample provided significant demand response, while the restaurants did not. Thermostat data provides further evidence that restaurants attempted to precool and reduce AC service during event hours, but were unable to because their air-conditioning units were undersized. On a $100^{\circ} \mathrm{F}$ reference day, load impacts of all participants during events averaged $14 \%$, while load impacts of office and retail buildings (excluding restaurants) reached $20 \%$. Overall, pilot participants including restaurants had 2007-2008 summer energy savings of $20 \%$ and bill savings of $30 \%$. About $80 \%$ of participants said that the program met or surpassed their expectations, and threequarters said they would probably or definitely participate again without the $\$ 120$ participation incentive.

These results provide evidence that energy efficiency programs, dynamic rates and load control programs can be used concurrently and effectively in the small business sector, and that communicating thermostats are a reliable tool for providing air-conditioning load shed and enhancing the ability of customers on dynamic rates to respond to intermittent price events.

Keywords: small commercial, demand response, dynamic pricing, smart thermostats, communicating thermostats, air-conditioning control (ACC), critical peak pricing (CPP) 


\section{Executive Summary}

\section{Introduction}

The Small Business Summer Solutions pilot was a research effort funded jointly by the Demand Response Research Center and the Sacramento Municipal Utility District (SMUD). The research pilot involved a market assessment and focus groups leading up to a summer pilot designed to test the response and perceptions of very small $(<20 \mathrm{~kW})$ commercial customers to an integrated energy efficiency and demand response program. This report describes each of these efforts along with a description of the data analysis and final results.

The first effort consisted of reviewing all commercial customer accounts to provide justification for targeting (1) certain customer types in (2) a bounded area smaller than the entire SMUD service territory. For (1), the market assessment report recommended targeting offices, retail stores and restaurants, focusing on customer types that were numerous (offices), high usage (restaurants), and both (retail). For (2), the report recommended an area of the SMUD service territory comprised of seven contiguous zip codes where the small commercial customers had unusually high electricity bills, based on the assumption that these customers were likely to need the most help with energy efficiency.

After the market assessment recommendations were finalized, two focus groups were conducted with target customer types in the target area. In the focus groups, 13 small commercial customers were provided with information about hypothetical air-conditioning control programs and dynamic rate offerings - and were encouraged to discuss their initial perceptions. Participants who preferred the dynamic rate did so because they perceived it to be more flexible, while those preferring air-conditioning control did so because they felt it was less hassle. Despite our initial focus on demand response, the overwhelming lesson we took away from the focus groups was that small commercial customers desperately wanted SMUD to help them with the efficiency of their buildings. Participants mentioned energy audits multiple times, but found SMUD's $\$ 300$ commercial energy audit fee too onerous for their very small operations. These findings justified a focus on offering small businesses (1) help with the energy efficiency of their buildings in exchange for occasional load shed, and (2) a portfolio of options to meet the needs of a diverse customer sector.

Based on the findings of the focus groups, we designed a marketing plan for the research pilot that emphasized a quid-pro-quo contract: agree to help SMUD by lowering peak load on event days and SMUD will provide individual help with the efficiency of your building. Customers choosing to participate would then have to choose between being placed a critical peak pricing rate and being paid for temperature setpoint increase of either 2 or 4 degrees. Recruitment letters were mailed out to the target population with return postcards and a program website address where letter recipients could find more information and sign up for the pilot. In all 1887 direct mail letters were sent out, 126 responded, and 78 customers ultimately signed up for the pilot, for an overall recruitment rate of 4.2 percent.

In the spring of 2008, communicating thermostats were installed in participant premises, miniaudits were conducted, participants were educated on the thermostat operation and new rate 
(where applicable), and initial survey data were collected. Between June 1 and September 30, 2008, 12 demand response events were called on days with forecast daily maximum temperatures between $87.7^{\circ} \mathrm{F}$ and $106.7^{\circ} \mathrm{F}$ in the Sacramento area. Participants and their thermostats were notified one day in advance. During events, thermostats of air-conditioning control (ACC) participants were set up by 2 or 4 degrees and could not be changed, while thermostats of critical peak pricing (CPP) customers were set up by the number of degrees programmed by the customer and could be changed at any time.

\section{Purpose}

The purpose of this study was to investigate the differential responses and perceptions of the target small business customers to different demand response program options and control strategies. Program options included critical peak pricing and remote air-conditioning control, both with a precooling option.

\section{Objective}

The objective for this pilot was to provide a better understanding of demand response issues in the small commercial sector, thus allowing SMUD to design programs that benefit both the District and its small business customers.

\section{Project Outcomes}

An analysis of hourly load data indicates that the offices and retail stores in our sample provided significant demand response, while the restaurants did not. Thermostat data provides further evidence that restaurants attempted to precool and reduce cooling services during event hours, but were unable to because their air-conditioning units were undersized. In contrast, office and retail buildings on both the CPP and ACC programs precooled on event days beginning about 8 a.m., and used significantly less power during events. On a $100^{\circ} \mathrm{F}$ reference day, load impacts of all participants during events averaged $14 \%$, while load impacts of office and retail buildings (excluding restaurants) reached $20 \%$.

Overall, pilot participants including restaurants had 2007-2008 summer energy savings of 20\% and bill savings of $20 \%$ to $30 \%$. About $80 \%$ of participants said that the program met or surpassed their expectations, and three-quarters said they would probably or definitely participate again without the $\$ 120$ participation incentive.

Some of the other important outcomes of this study include:

Recruitment. Offices and retail were about twice as likely to sign up for the pilot as were restaurants. Restaurant owners in focus group indicated that lowering energy usage between 4 and 7 p.m. would be difficult because it overlapped the peak dinner hours. In addition, airconditioning was considered a non-discretionary load for most restaurants, who constantly battled heat generated from cooking and refrigerator exhaust.

Efficiency. Compared to the summer of 2007, pilot participants saved $20 \%$ more energy than a control group (after normalizing for weather).

Demand Response. Offices and retail stores on both the ACC and CPP programs had the greatest demand response of between 0.6 and $0.8 \mathrm{kWh} / \mathrm{h}$, averaging $20 \%$ peak load reduction during events. Participating restaurants modified setpoints in response to events, but load reductions 
were not realized because the $\mathrm{AC}$ units, running flat out, could not maintain requested temperatures.

Communicating Thermostats. On average, participants with communicating thermostats dropped nearly four times as much peak load as those without them.

Bill Impacts. All but four of the CPP participants benefited from the CPP rate relative to the standard small business rate. Average CPP bill savings were 5 percent for all three business types. Note that these savings are in addition to the energy efficiency savings discussed above.

Precooling. The pilot significantly increased the use of precooling among participants. Despite precooling, total participant usage did not increase on event days.

Overrides. About 3 percent of ACC participants overrode the event settings during events, and about 5 percent of CPP participants modified their own default thermostat setpoint during events.

Satisfaction Rate. About 80 percent of participants said that the program met or surpassed their expectations. About three-quarters said they would probably or definitely participate again without the $\$ 120$ pilot participation incentive.

Communications Technology. The communications technology (Radio Data System or RDS) successfully broadcast system alerts to automatically adjusting thermostat setpoints in near real time.

\section{Conclusions}

Despite the small number of participants in the study, customer responsiveness and comprehension with the pilot program was high. We found the Summer Solutions research pilot to be a three-way win, benefiting SMUD, pilot participants, and society in general: SMUD benefited by receiving $20 \%$ peak load reductions on event days, participants benefited from $20 \%$ to $30 \%$ lower bills, and society benefited from the $20 \%$ energy-efficiency savings. Given the current pace of communicating thermostat evolution and cost reductions associated with the technology recently noted in the industry, we expect a Summer Solutions type program that includes communicating thermostats to be one of the most popular and possibly most costeffective demand response options available for small businesses.

\section{Recommendations}

We learned many lessons over the course of this study - some expected, some not. Below are a few recommendations for future programs and pilots based on our experience with this study.

- Utilities should not hesitate to target the small commercial sector, in particular small offices and retail shops, for integrated EE-DR programs

- Demand response programs should provide participants with energy efficiency assistance - especially envelope enhancements

- Small commercial demand response program offerings should give customers a choice between a dynamic rate and load/temperature control 
- SMUD should seriously consider expanding this voluntary program offering to all of their small commercial customers (following a cost-effectiveness study)

\section{Benefits to California}

This study provides California State policy makers with evidence that dynamic rates and load control programs can be used concurrently and effectively in the small business sector. This study also informs California State energy agencies that it is possible to use Radio Data System communications technology to broadcast system alerts to the mass market in support of dynamic rates, demand response programs, and utility service messages. This last capability would exist even in the event of a power outage. Finally, this study provides further evidence that communicating thermostats are a viable demand response technology, capable of automatically increasing setpoints to a either a customer-determined or utility-determined level, thus providing air-conditioning demand response within seconds or just a few (less than five) minutes. 


\subsection{Introduction}

\subsection{Background}

Demand Response programs have existed in California for several decades. Since California's energy crisis in 2000 and 2001, improving electric demand response through incentive programs and rate adjustments has become a priority at both the state and federal levels. For example, the U.S. Energy Policy Act of 2005 requires utilities and state legislators to consider time-varying rate options, and required the Federal Energy Regulatory Commission to hold hearings investigating demand response programs and advanced metering technologies.

Several different demand response incentive structures exist, though two are of particular interest, having previously been studied and piloted by several utilities. Since the 1980's, utilities have offered Direct Load Control (DLC) programs, most notably air-conditioning control (ACC), which offer payments in exchange for intermittent reductions in customer air conditioning via switches remotely controlled by the utility. Recent plans to install advanced metering infrastructure in many utilities in California have sparked increased interest in encouraging demand response through dynamic pricing like Critical Peak Pricing (CPP), which provides time-varying price incentives for customers to reduce their own electricity use manually or through the use of enabling technologies that can sense and respond to the variable rate.

A recent study in California showed that small commercial customers with enabling thermostats dropped 13 percent of their peak load in response to Critical Peak Pricing events (CRA 2005). Even so, small commercial customers can be complicated targets for demand response programs and tariffs. Customers tend to be fairly heterogeneous, have limited time and money to devote to energy management, and are skeptical about the possible tradeoffs between money saved and business lost. As a result, the small commercial sector has been relatively unaddressed by energy demand response research, and very few demand response programs are offered to this sector.

\subsection{Project Scope and Goals}

The goal for this pilot is to provide a better understanding of demand response issues in the small commercial sector, thus allowing SMUD to design programs that benefit both the District and its small business customers.

The pilot program was intentionally offered on a voluntary basis so that results would be representative of a voluntary program. The results are not intended to be statistically representative of the entire small commercial sector. 


\subsection{Project Overview and Schedule}

The first part of the study identified small commercial customers most likely to participate in and respond to demand response programs and events. The results of this investigation targeted offices, retail, and restaurants as good candidates.

The second part of the study consisted of focus groups, which investigated, among other things the extent to which interactions of the various players (business owners, business managers, building owners, and/or building occupants) might affect demand response program participation and response. Also discussed were issues related to demand response capabilities at small businesses. The results of this work were used to refine the design and implementation of the field study.

The field study - known to participants as the Small Business Summer Solutions Research Pilot - was implemented in the Sacramento Municipal Utility District (SMUD) during the summer of 2008. The field study was designed to investigate the differential responses and perceptions of small businesses customers to different demand response program options and control strategies, comparing the three business and two program types in terms of load impacts and satisfaction with the program.

Table 1 outlines the major phases of project activity in 2008 and describes corresponding research tasks.

Table 1. Summer Solutions Research Schedule, 2008

\begin{tabular}{|c|c|c|}
\hline Task & Dates & Research Actions \\
\hline Recruitment & Feb - Mar & $\begin{array}{l}\text { - } \quad \text { Mail out recruitment letters } \\
\text { - Collect signed Participation Agreements with program } \\
\text { choice indicated }\end{array}$ \\
\hline $\begin{array}{l}\text { Participant } \\
\text { Preparation }\end{array}$ & Mar - May & $\begin{array}{l}\text { - Install, program and test thermostats and loggers } \\
\text { - } \quad \text { Distribute participation incentives, information } \\
\text { packets, display placards, and magnets } \\
\text { - Spring Survey: collect information on buildings and } \\
\text { businesses } \\
\text { - } \quad \text { SMUD installs meters }\end{array}$ \\
\hline Field Study & Jun - Sep & $\begin{array}{l}\text { - Ongoing data collection from meters and loggers } \\
\text { - Call } 12 \text { events } \\
\text { - Event Surveys: collect information on experience with } \\
\text { most recent event }\end{array}$ \\
\hline $\begin{array}{l}\text { Data Collection } \\
\text { and Analysis }\end{array}$ & Oct - Dec & $\begin{array}{l}\text { - } \text { Retrieve logger data from sites } \\
\text { - } \quad \text { Get billing and meter data from SMUD } \\
\text { pilot } \\
\text { - Anarvey: collect information on experiences with } \\
\text { individually and linked }\end{array}$ \\
\hline
\end{tabular}




\subsection{MARKET RESEARCH}

The Sacramento Municipal Utility District (SMUD) was established in 1946 and is currently the nation's sixth largest community-owned electric utility in terms of customers served. SMUD serves over half a million customers in Sacramento County, spanning 900 square miles. Peak demand for the SMUD system, measured on July 24, 2006, was 3.3 gigawatts.

Figure 1 shows the location of the SMUD service territory, forecast climate zone 6 , in relation to the state of California.

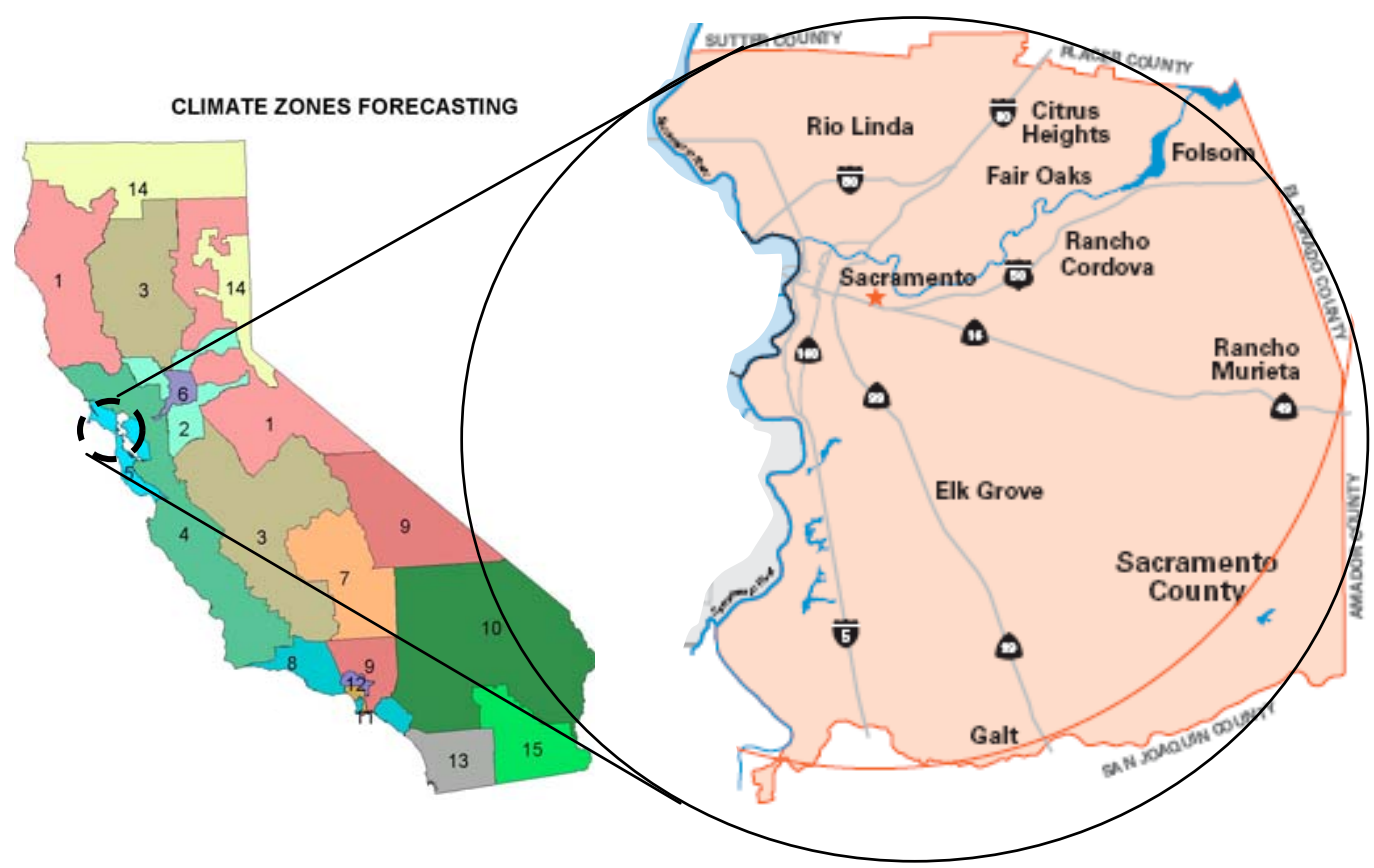

Figure 1. SMUD service territory

SMUD has over 30,000 accounts on the small commercial tariff, known within SMUD as the GSN tariff. To qualify, commercial customers must maintain a monthly maximum peak demand below $20 \mathrm{~kW}$. Customers with peak demands above $20 \mathrm{~kW}$ for three or more consecutive months are automatically bumped into the 20-200 kW tariff, known as the GSS tariff.

SMUD's current demand response program portfolio includes the following:

- Peak Corp, Air Conditioning Load Management - More than 100,000 of SMUD's residential customers receive modest incentives (about $\$ 10$ per year) to allow the District to cycle off their air conditioner under emergency conditions.

- Voluntary Load Curtailment - At SMUD's request, businesses voluntarily drop load during critical hours. There are no financial benefits or penalties and no metering of load drop. 
- Special Curtailment Agreements - Through contracts, large commercial customers agree to reduce a specified amount of load when called, in return for specified incentives.

Small commercial customers are highly underrepresented in these demand response programs. In fact, of SMUD's demand response programs, only one - the Voluntary Load Curtailment program - allows small commercial customers to participate. Given the voluntary nature of the Voluntary Load Curtailment program, however, it is safe to say that none of the existing demand response programs at SMUD give small commercial customers the opportunity to earn or save money by dropping load on critical days.

\subsection{Target Businesses and Area}

The goal of the market assessment was to choose a target subset of the small commercial population that would be likely to respond well to demand response programs, thus improving overall program cost-effectiveness.

\subsubsection{Business Types}

Table 2 shows summary characteristics, as of July 2007, of SMUD's small commercial customers divided into the eleven building types developed by the California Energy Commission. Based on these values, offices, restaurants, and retail stores were chosen as the target population for this pilot as described in the following sections.

Table 2. Small commercial customer characteristics by building type, July 2007

\begin{tabular}{lrrr}
\hline Building Type & Customers & Avg. Usage (kWh) & $\begin{array}{r}\text { Avg. July } \\
\text { 2007 Bill }\end{array}$ \\
\hline College & 78 & 1,455 & $\$ 166$ \\
\hline Food/Liquor & 297 & 3,116 & $\$ 348$ \\
\hline Health Care & 258 & 1,889 & $\$ 213$ \\
\hline Hotel & 45 & 1,666 & $\$ 191$ \\
\hline Miscellaneous & 3,911 & 1,445 & $\$ 165$ \\
\hline Office & 14,989 & 945 & $\$ 110$ \\
\hline Refr Warehouse & 91 & 2,045 & $\$ 231$ \\
\hline Restaurant & 763 & 3,827 & $\$ 426$ \\
\hline Retail Store & 1,811 & 1,746 & $\$ 199$ \\
\hline School & 368 & 1,434 & $\$ 162$ \\
\hline Warehouse & 840 & 1,341 & $\$ 155$ \\
\hline Not specified & 7,400 & 953 & $\$ 111$ \\
\hline Grand Total & 30,851 & 1,179 & $\$ 136$ \\
\hline
\end{tabular}

\section{Office Buildings}

Office buildings comprise about half of SMUD's small businesses. On average, the small offices have lower energy use and summer bills than other business types. In aggregate, however, peak energy use is likely to be substantial simply because there are so many small offices. One concern at this stage was whether offices - which are likely to shut down operations at 5 or 6 p.m. - would contribute savings after hours. 


\section{Restaurants}

Restaurants have the highest energy use and, correspondingly, the highest electricity bills. These businesses are likely to have large amounts of refrigeration running 24 hours a day, seven days a week and additionally run air conditioning during business hours. On one hand, restaurants could be good candidates for demand response programs because they have such high load and high bills. On the other hand, this high load might not be considered discretionary since system peaks tend to occur precisely when restaurants need to prepare and serve dinner.

\section{Retail}

Like offices, retail stores are likely to have very little energy use outside of business hours, but high air conditioning use on summer afternoons and evenings. Unlike offices, however, most retail stores continue business operations past 5 or 6 p.m. Electricity bills for retail businesses are moderate to high, so one might hypothesize that they are more likely than offices to be interested in programs promising lower bills or rewards, particularly in instances when their profit margins are low to moderate. Thus, retail stores were also good candidates for thermostat-based demand response programs.

\section{Other building types}

The remaining building types are less desirable for demand response programs for a variety of reasons.

The miscellaneous and uncategorized businesses are likely to be too diverse to reach any general conclusions. This is not to say that the miscellaneous category does not have demand response potential, but that a behavioral study is probably not appropriate. Should a betterdefined sub-categorization of the miscellaneous category be created, there are likely to be subcategories with excellent opportunities for behavioral research.

Small colleges, hotels and warehouses are so few that an in-depth study would not provide much potential for broad use of lessons learned.

Health care and schools, while potentially good candidates for demand response programs, are in aggregate likely to have lower peak energy use than the business types we have chosen for this study.

\subsubsection{Geographic Location}

Because this study involved several visits to participant premises, the study sample was limited to as small a geographic area as possible. After a careful analysis of customer populations and bills by zip code, seven contiguous zip codes were chosen as the target area as shown in Figure 2. 


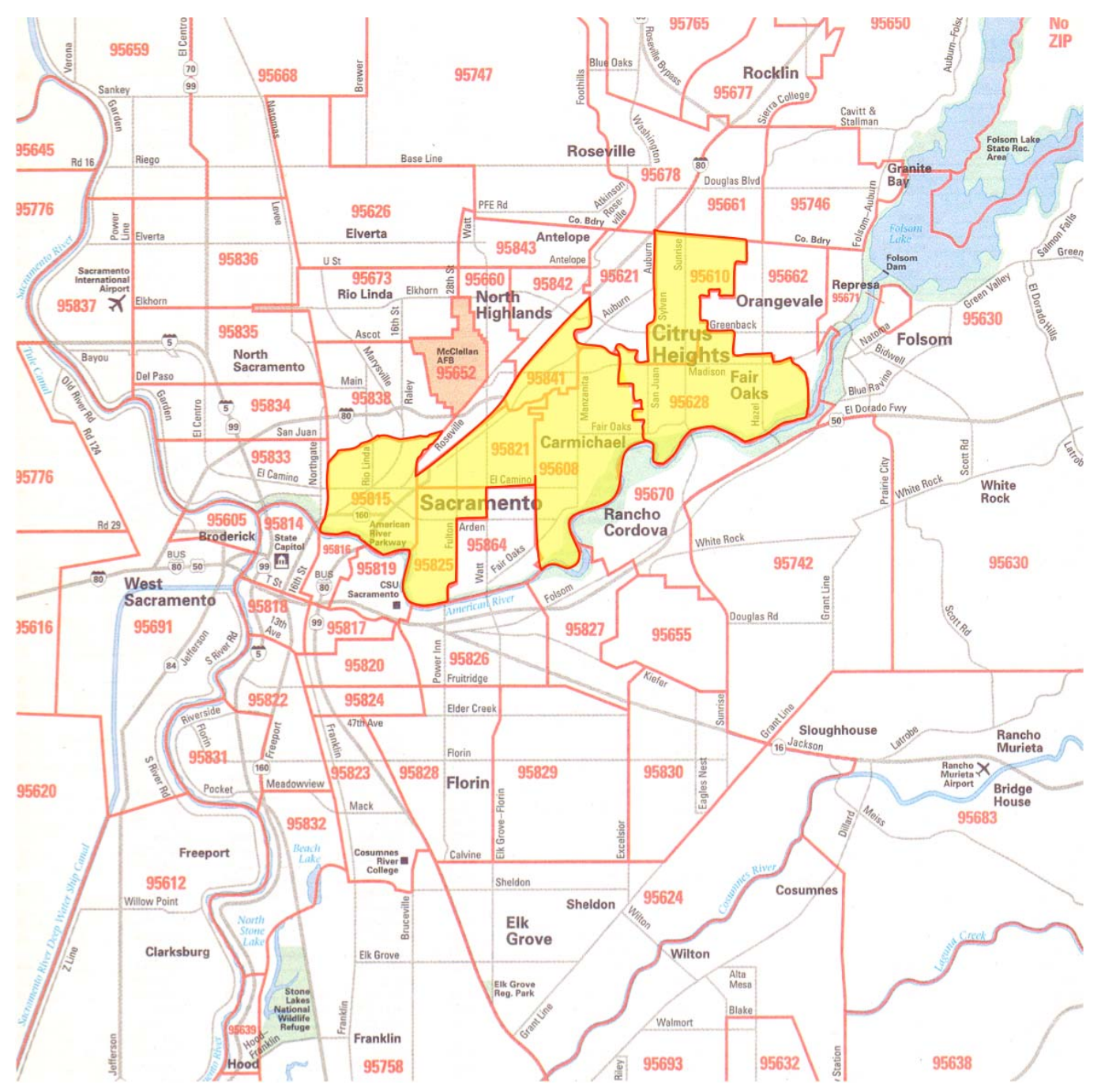

Figure 2. Target zip codes in the SMUD service territory 
Table 3 summarizes the total number of small business customers in each target zip code.

Table 3. Number of businesses in the target area, by zip code

\begin{tabular}{lrrrr}
\hline $\begin{array}{c}\text { Zip } \\
\text { Code }\end{array}$ & Office & Restaurant & \multicolumn{1}{l}{ Retail Store } & \multicolumn{1}{l}{ Total } \\
\hline 95608 & 1127 & 57 & 88 & 1282 \\
\hline 95610 & 956 & 61 & 113 & 1149 \\
\hline 95628 & 745 & 45 & 72 & 870 \\
\hline 95815 & 238 & 15 & 97 & 354 \\
\hline 95821 & 814 & 37 & 101 & 970 \\
\hline 95825 & 1397 & 59 & 145 & 1613 \\
\hline 95841 & 774 & 37 & 136 & 961 \\
\hline Total & 6051 & 311 & 752 & 7199 \\
\hline
\end{tabular}

\subsection{Focus Groups}

The purpose of focus groups in this study was to collect information from real customers to refine the research design. Two focus groups were held with a total of 13 customers: 5 retail, 4 offices, and 4 restaurants.

Generally, we found that focus group participants were eager to partner with SMUD, both to learn about energy saving measures and to help SMUD with peak load issues. Energy audits were unanimously popular, but costs were perceived to be high and benefits uncertain. One idea was that SMUD should consider offering very simple and discounted on-site audits for small commercial customers, using the contact opportunity to recruit for both energy efficiency and demand response programs.

When presented with a general description of demand response program goals and characteristics, nearly all participants were confident they could provide some load relief during critical events. Program characteristics that increased the likelihood of participation included options for controlled end-uses and event timing, both time of day and length of event.

Participants were presented with the options of air conditioning load control and dynamic pricing under the assumption that both would provide similar discounts. Those preferring the dynamic pricing option considered it more flexible with respect to affected appliances and ability to not respond on certain days. Concerns with the dynamic pricing program revolved around an unwillingness to manually control appliances in real time. Those preferring the air conditioning control program said they thought it would be less hassle, but there were concerns about allowing the utility to control the air conditioning.

In both focus groups, there were also concerns that the utility would collect information about the customer through the communicating thermostat. This discussion implied that, when 
informing participants about the program, emphasis should be placed on the fact that the thermostat will not send any customer data to SMUD without the customer's permission.

Participants expressed interest in options that provided the flexibility small commercial customers might need to commit to reducing peak load: for example, flexibility in how much, how often, at what time, and for how long customers need to respond.

For the Critical Peak Pricing program, focus group participants stressed the importance of being provided information about what kinds of actions would provide the biggest benefit. This implies that there should be some translation from appliance use to energy use to costs and savings. 


\subsection{FIELD STUDY IMPLEMENTATION}

The target customers were offered participation payments, recognition, energy efficiency recommendations and free thermostats in exchange for their participation in the Small Business Summer Solutions Research Pilot. During the four-month experiment from June through September 2008, we chose twelve days to call demand response events, which occurred during SMUD's peak period from 4 to 7 p.m. All participants had the option to have installed a free communicating thermostat that could be programmed to pre-cool their building in the hours before an event and increase AC temperature setpoints during the event periods.

\subsection{Participant Benefits}

Benefits of the pilot included:

- Efficiency information. The pilot provided participants with several sources of information - via site visits, websites and brochures - on best practices and rebates.

- A $\$ 120$ participation payment, distributed in two $\$ 60$ installments, one at the beginning and one at the end of the study.

- A new thermostat installed for free. Customers received a new Programmable Communicating Thermostat and had it installed for free if they wanted. Benefits of the thermostat include: ability to program up to four set points per day (each day can be scheduled independently) and the option of automatic pre-cooling on event days. The thermostats also provided notification of events on the thermostat screen and AC temperature reset.

- A display placard indicating participation in the pilot (Figure 3).

- The opportunity for lower energy bills by shifting load out of the peak period into cheaper periods, or by conserving during events and overall.

- Good will. Partaking in demand response can give customers the feeling that they are doing their part for the environment and to help reduce strain on the electric grid during peak times, improving electric reliability for everyone. 


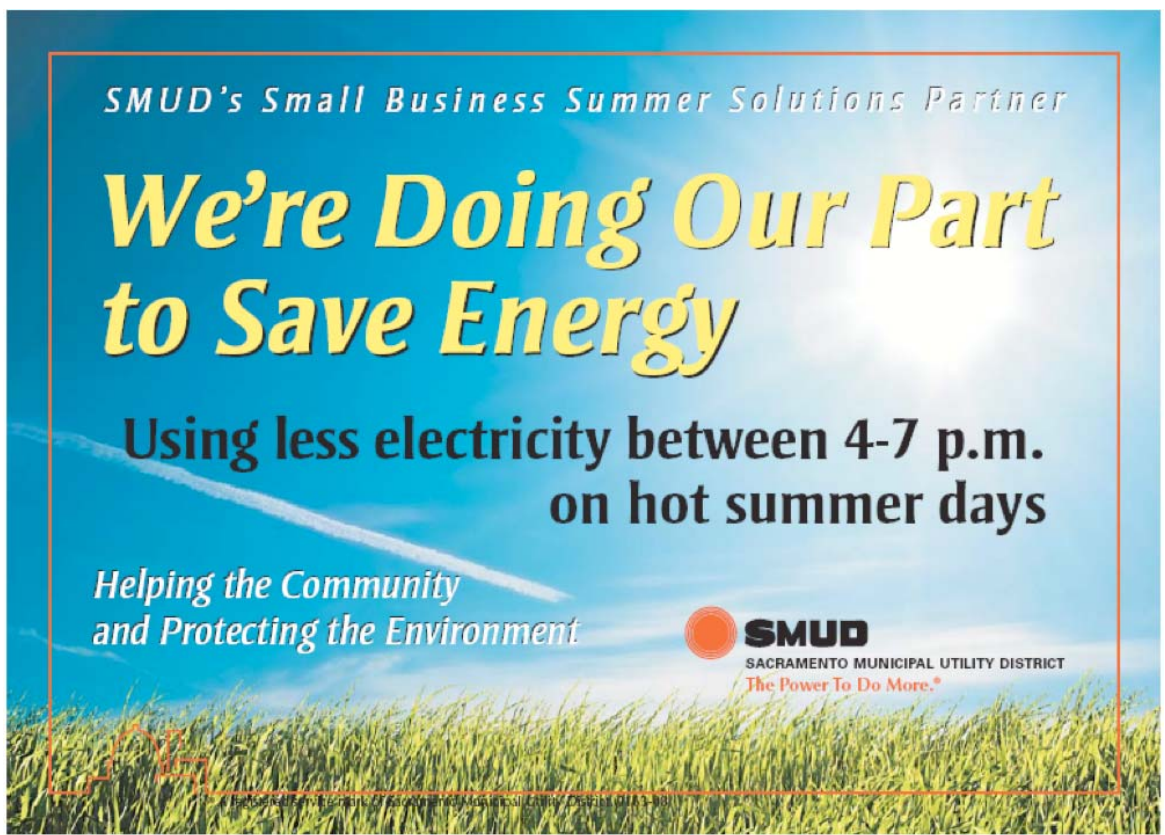

Figure 3. Display Placard distributed to participants

\subsection{Program Options}

The Small Business Summer Solutions Research Pilot offered two electric tariff options, allowing participants to choose the one that best suited their business needs. In both cases, 12 demand response events were called between June 1 and September 30, 2008, when the pilot tariffs were in force. The two programs were designed to offer roughly equivalent benefits assuming similar customer load drop during these events.

\subsubsection{Critical Peak Pricing (CPP)}

The CPP option used a Time of Use rate to reward efficiency or load shifting every day, plus a Critical Peak component to reward load shifting and temporary load reductions during events.

Table 4 summarizes the experimental CPP tariff and compares it to the existing small business rate (GSN). 
Table 4. CPP tariff compared to the standard small commercial rate

\begin{tabular}{|c|c|c|c|c|c|}
\hline Price Tier & Time Period & $\begin{array}{c}\text { GSN } \\
\text { (\$/kWh) }\end{array}$ & $\begin{array}{c}\text { CPP } \\
(\$ / k W h)\end{array}$ & $\begin{array}{c}\text { Hours } \\
\text { per } \\
\text { Summer }\end{array}$ & $\begin{array}{l}\text { \% of } \\
\text { Time }\end{array}$ \\
\hline Critical peak & $\frac{12 \text { Event weekdays }}{\text { 4:00 P.M. - 7:00 p.m. }}$ & $\$ 0.113$ & $\$ 0.572$ & 36 & $1 \%$ \\
\hline Super peak & $\frac{\text { Normal Weekdays }}{4: 00 \text { p.m. - 7:00 p.m. }}$ & $\$ 0.113$ & $\$ 0.131$ & 219 & $8 \%$ \\
\hline On peak & $\begin{array}{c}\text { All Weekdays } \\
\text { 12:00 p.m. - 4:00 p.m. } \\
\text { 7:00 p.m. - 10:00 p.m. } \\
\text { Weekends \& Holidays } \\
\text { 12:00 p.m. - 10:00 p.m. }\end{array}$ & $\$ 0.113$ & $\$ 0.099$ & 881 & $31 \%$ \\
\hline Off peak & All Other Hours & $\$ 0.113$ & $\$ 0.085$ & 1708 & $60 \%$ \\
\hline
\end{tabular}

On weekdays, the experimental CPP rate was lower than the GSN in all hours except for the three-hour peak period. On weekends and holidays, the experimental rate was lower than the existing rate for all hours of the day, so businesses that were open on the weekend could take advantage of these low rates.

During the 12 event days, participants were charged 57.2 cents per kilowatt-hour (kWh) during peak hours. During this time, participants were asked to reduce electricity use in any way that made sense for their business. Focus groups participants suggested that restaurants might lower the lighting during this time, while offices or retail might prefer to reduce the air conditioning load slightly.

The optional communicating thermostats allowed participants to automatically pre-cool their buildings before the event hours, and then increase the set point at the onset of the event period. $\mathrm{CPP}$ participants were allowed to choose the default temperature offset for events and to change thermostat set points at will during events.

\subsubsection{Air-Conditioning Control (ACC): 2 or 4 Degrees}

Participants choosing the ACC program stayed on their original flat GSN rate (see 
Table 4), but received a $\$ 5$ or $\$ 10$ monthly credit on their bill in exchange for a 2- or 4-degree offset, respectively, during demand response events. ACC participants were required to have a thermostat or thermostats installed and programmed to respond to events. Participants were told that they were not allowed to override the event settings - but overrides were technically feasible; i.e., the thermostats would allow the user to change event settings after answering affirmatively to an "Are you sure?" screen. All overrides were recorded for later analysis.

\subsubsection{Precooling Option}

All participants had the option to program their communicating thermostat to automatically pre-cool their building by four degrees in the four hours preceding events. The pre-cooling strategy could be enabled or eliminated by the user at any time.

\subsection{Meters and Enabling Technologies}

\subsubsection{Communicating Thermostat Hardware}

The communicating thermostat hardware enabled precooling and temperature offsets on event days for both programs, and recorded several variables for analysis. The thermostat hardware consisted of four main parts: the thermostat display unit, the control unit, an FM receiver, and a data logger.

Communication to the thermostats was accomplished using Radio Data System or RDS. RDS utilizes a $57 \mathrm{kHz}$ subcarrier of the standard FM broadcast system to carry data at over 1,000 bits per second. The system was originally designed to send data related to musical broadcasts, including time, artist information and station identification. For this study, Sacramento radio station KXJZ (90.9 FM) provided the RDS transmission to the communicating thermostats.

The communicating thermostat was custom made based on the Residential Control Systems TR40, a thermostat currently available in the retail market (Figure 4). The TR40 has a menudriven display capable of both text and graphics on multiple display screens. 


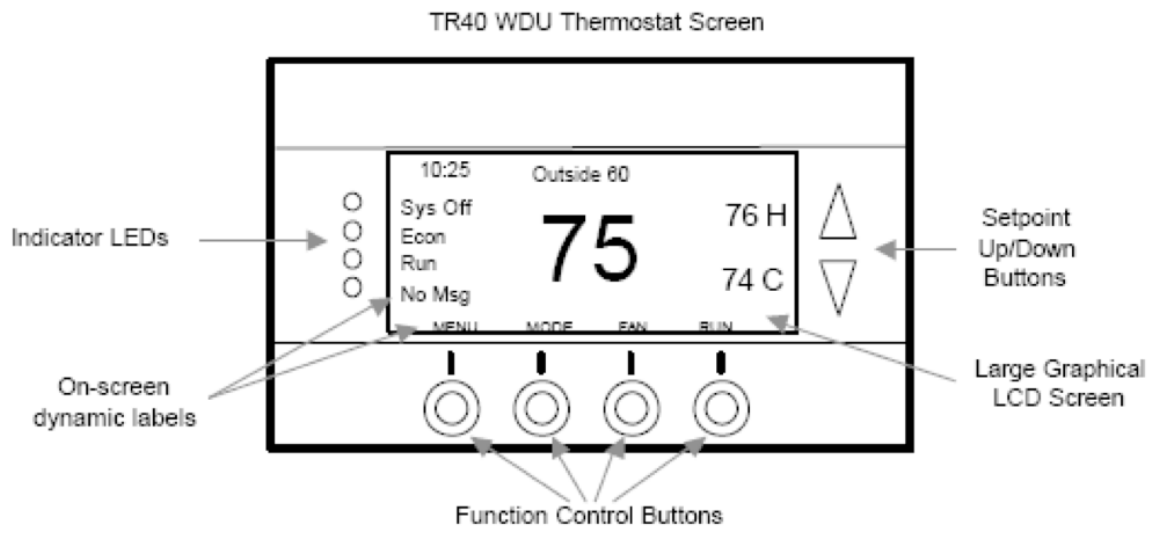

Figure 4. Residential Control System's TR40 Display Unit

The controller for the TR40 is separate from the display, and is connected to the thermostat wire at any point between the HVAC unit and the display. A removable RDS receiver was connected to the controller through the logging unit, which collected information about set points, schedules, compressor status and indoor temperatures.

A total of one hundred Residential Control Systems thermostats were available for this study. All thermostats, receivers, and loggers were tested by Residential Control Systems prior to installation to ensure proper operation. The thermostats received an RDS signal indicating event start and stop time, which was always 4 to 7 p.m., and responded to these event calls according to their tariff design and programmed settings. CPP participants could have one or no thermostat. ACC participants were required to replace all thermostats in the building and were held to a maximum of two.

\subsubsection{Meters}

SMUD installed interval meters and provided HMG with a list of meter numbers linked to each pilot participant. On installation, SMUD began collecting 15-minute usage data via their MV-90 remote data collection system.

\subsection{Recruitment and Participation}

The goal of the marketing strategy for the pilot was to recruit a final sample of one hundred participants by the end of February 2008. The market analysis recommended that SMUD focus efforts for the demand response pilot on offices, restaurants, and retail businesses. These business types are not evenly represented in the small business population. To maximize validity within each category, the target sample size was set at 33 businesses of each type.

Table 3 shows the final recruitment and participant numbers, by business type. Since the number of recruitment letters is equal to all of the small business customers in the target area, these numbers represent the actual business type ratios for that area and are similar to district- 
wide ratios. At $4.2 \%$, the participation rate for this voluntary program offering was unexpectedly high when compared to participation rates for similar time-of-use offerings, which tend to be around 1 or 2 percent. Note that the participation rates for office and retail are direct results of recruitment letters only, while the participation rate for restaurants was more than doubled by face-to-face recruitment efforts initiated when it became clear that restaurant participation goals would not be met.

Table 5. Participation agreements and rate, by business type

\begin{tabular}{lccc}
\hline $\begin{array}{l}\text { Building } \\
\text { Type }\end{array}$ & $\begin{array}{c}\text { Recruitment } \\
\text { Letters }\end{array}$ & $\begin{array}{c}\text { Participation } \\
\text { Agreements }\end{array}$ & $\begin{array}{c}\text { Participation } \\
\text { Rate }\end{array}$ \\
\hline Office & 893 & 35 & $3.9 \%$ \\
\hline Retail & 729 & 31 & $4.3 \%$ \\
\hline Restaurant & 265 & $12^{*}$ & $4.5 \%$ \\
\hline Overall & 1887 & 78 & $4.2 \%$ \\
\hline
\end{tabular}

* Includes seven participants recruited in person

\subsubsection{Recruitment Procedure}

Recruitment letters were the primary strategy to inform the potential participants of the opportunity to sign up for the pilot. SMUD mailed out the 1,887 letters describing the project, customer value, and customer responsibility, and directed customers to indicate their interest by responding with a few basic pieces of information via postcard, phone, or online.

- The letter conveyed the following basic messages:

- That the targeted customers are part of a group special for being small business customers with unusually high electricity bills.

- That the District is offering participation in this pilot both to help them reduce their own bills and to test the program for expansion to other customers.

- That the District will provide participants with several benefits, including a free thermostat, personalized energy information, \$120 in cash incentives, and the opportunity to save money on their bills.

- That the participants will help reduce the frequency of emergency conditions, and the need for rotating outages when emergency conditions do occur.

Those who agreed to participate were subject to a few questions to verify eligibility and were then sent a participation agreement. The agreement required that the person named on the SMUD account choose a program option and sign the agreement.

A small response from restaurants required follow-up phone calls and site visits to eligible restaurants. While the extra effort did roughly double the number of participating restaurants to 12 , the target population of 33 restaurants was not achieved.

\section{Screening}


Four screening criteria were used to limit the database of over 30,000 small commercial customers to the final 1,887 potential participants as follows.

Include zip codes 95608, 95610, 95628, 95815, 95821, 95825, 95841.

Include Offices, Restaurants, and Retail.

1. Excluded NAICS codes 531110, 531120, 531190 - codes indicating property management companies.

2. Exclude customers using $<20 \mathrm{kWh}$ in December 2007 or $<200 \mathrm{kWh}$ in July 2007.

\subsubsection{Participant Characteristics and Program Choices}

At the beginning of the summer, the Summer Solutions pilot included 78 small businesses: 35 offices, 31 retail stores and 12 restaurants (Table 6). Of these, roughly two-thirds chose the CPP option, while the remaining one-third chose either the 2-degree or 4-degree ACC option. About $80 \%$ of CPP participants, for whom communicating thermostats were optional, chose to have one installed. All ACC participants were required to have communicating thermostats installed.

Table 6. Participant program choices (including PCTs) by business type

\begin{tabular}{|c|c|c|c|c|c|c|}
\hline & $2^{\circ} \mathrm{ACC}$ & $4^{\circ} \mathrm{ACC}$ & CPP & $\begin{array}{l}\text { Total number of } \\
\text { participants }\end{array}$ & $\begin{array}{l}\text { Participants with } \\
\text { one or more } \\
\text { communicating } \\
\text { thermostats }\end{array}$ & $\begin{array}{l}\text { Number of } \\
\text { communicating } \\
\text { thermostats } \\
\text { installed }\end{array}$ \\
\hline Office & 1 & 11 & 23 & 35 & 30 & 31 \\
\hline Restaurant & 3 & 1 & 8 & 12 & 9 & 11 \\
\hline Retail & 3 & 8 & 20 & 31 & 27 & 29 \\
\hline Total & 7 & 20 & 51 & 78 & 66 & 71 \\
\hline
\end{tabular}

The Critical Peak Pricing rate was chosen most often. This may have been due partly to the fact that a significant number of participants were ineligible for the temperature control option due to various limitations. Some customers had no central air-conditioning; others had more than two zones. For many, the potential for savings was greater on the Critical Peak Pricing rate, particularly business that did not feel they could significantly contribute to air conditioning load drop during the 4 to 7 p.m. window consistently, but were open for business on the weekends.

Table 7 summarizes other important characteristics of the participant population, including building age, size, and ownership; number of employees and closing time. More detailed descriptions of these attributes are provided in the following sections.

Table 7. Participant characteristics: buildings, staff and schedule

\begin{tabular}{|c|c|c|c|c|c|c|}
\hline $\begin{array}{l}\text { Business } \\
\text { Type }\end{array}$ & $\mathrm{N}$ & $\begin{array}{l}\text { Median } \\
\text { Age }\end{array}$ & $\begin{array}{c}\text { Median } \\
\text { Size }\end{array}$ & $\begin{array}{l}\text { Building } \\
\text { Ownership }\end{array}$ & $\begin{array}{c}\text { Avg. \# of } \\
\text { Employees }\end{array}$ & $\begin{array}{c}\text { Median } \\
\text { closing time }\end{array}$ \\
\hline
\end{tabular}




\begin{tabular}{lcccccc} 
& & (years) & $\left(\mathrm{ft}^{2}\right)$ & $(\%)$ & & \\
\hline Office & 35 & 8 & 1563 & 37 & 3.1 & $5: 00$ p.m. \\
\hline Restaurant & 31 & 42 & 2108 & 0 & 2.8 & $9: 00$ p.m. \\
\hline Retail & 12 & 39 & 3291 & 0 & 2.3 & $6: 00$ p.m. \\
\hline
\end{tabular}

\section{Building Age, Size and Ownership}

Participant buildings ranged, in both size and age. One retail warehouse had been built around 1900 while one of the office buildings was constructed in 2006. In general, office buildings were much newer than either restaurants or retail structures.

The targeting of small businesses helped to dictate the size of eligible participants (Figure 5). Offices that signed up were the smallest of the three business types, averaging less than 1,400 square feet.

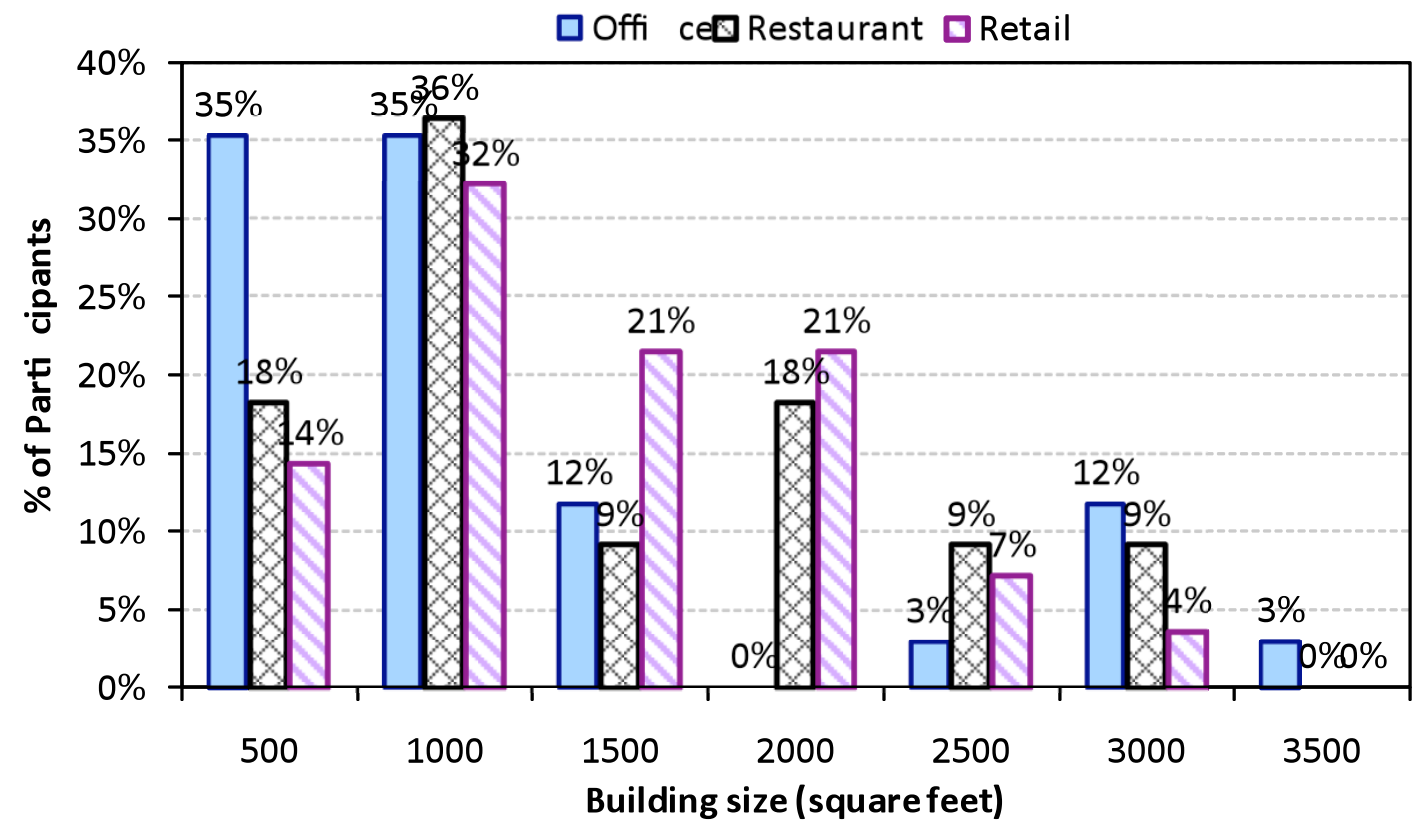

Figure 5. Building size by business type

Of the participants, 13 offices owned their buildings, while the rest rented. Program choices of building owners were not significantly different from the group of participants as a whole: ten chose the CPP rate while the other three chose the $4^{\circ}$ ACC.

\section{Point of Contact, Staff and Hours of Operation}

The owner was the main point of contact for 68 of the 78 businesses in this study. Of the remaining 10 contacts, 9 were managers and 1 was an administrative assistant. 
On average, offices had the most employees, averaging about 3 per site. Restaurants had an average of 2.8 staff with the largest restaurant employing 4 staff at any given time. Retail shops averaged just 2.3 staff, the largest employing 6 at any given time. There was at least one participant of each business type that employed one staff member at a time.

In total 8 participants ( 1 office, 2 restaurants, and 5 retail shops) were closed on Mondays, and one office was closed on Fridays. Figure 6 shows the scheduled closing times of the participants. Not all businesses had clearly defined opening and closing times, but in those cases, the contact provided an approximation.

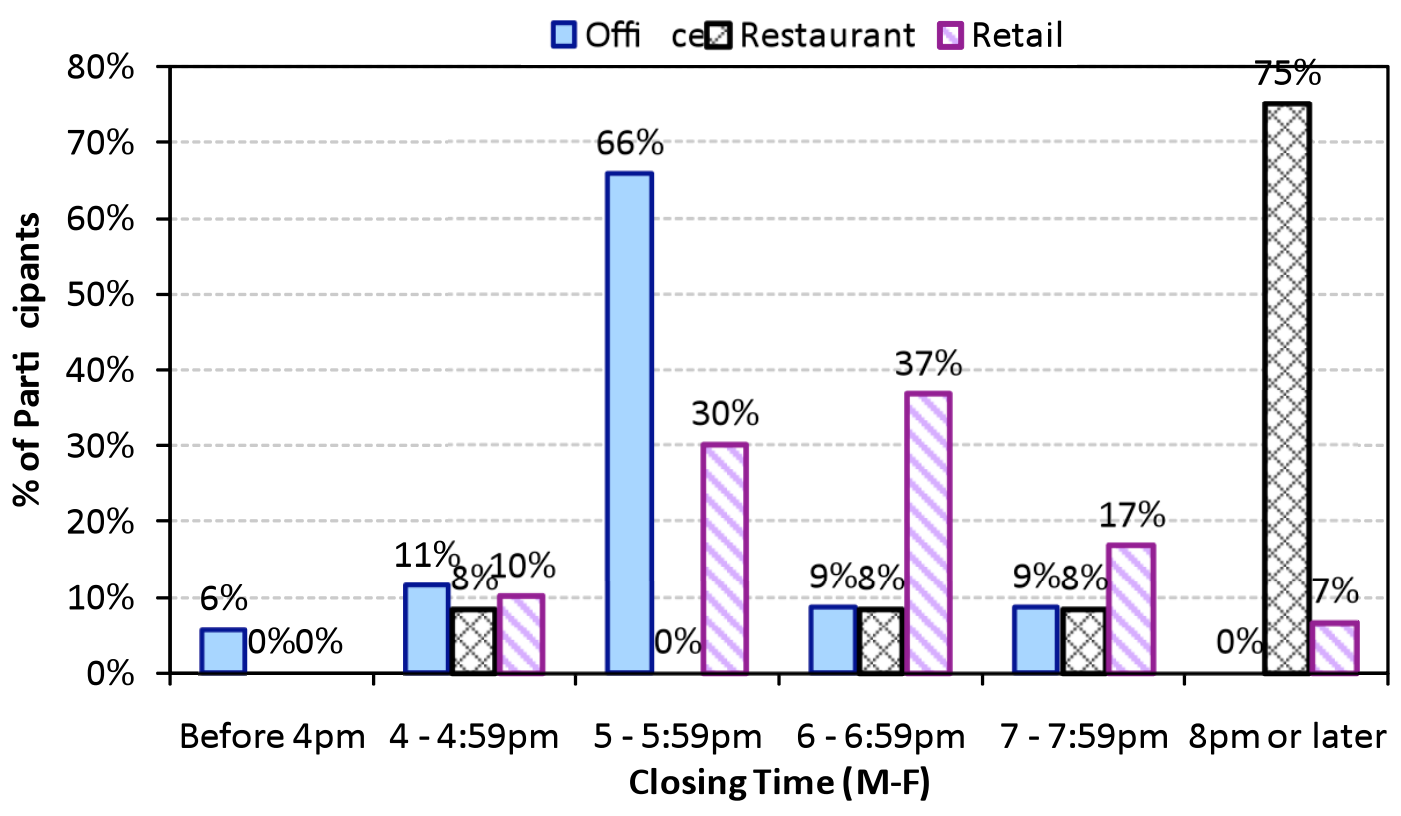

Figure 6. Closing time by business type

Offices most consistently closed at 5 p.m., however they ranged from as early as 1 p.m. to as late as 7 p.m. Restaurants had later closing times, as would be expected, ranging from 4 p.m. to 2 a.m. Retail shops closed anywhere between 4 p.m. and 8 p.m., with 6 p.m. being the most common closing time.

\subsection{Participant Preparation and Education}

\subsubsection{Participant Education}

In addition to personal attention provided by the research team, participants were provided several opportunities to review information about the pilot and actions they could take as participants. A website was posted prior to mailing the recruitment letters so that prospective participants could review program details at their leisure. Other program materials were physically handed to participants at the time of the Spring Survey. Emails throughout the summer reminded participants of specific strategies that could be taken during events. 
Finally, SMUD bills provided feedback on usage. For CPP participants, usage information was provided by price tier, and bill savings or increases relative to the standard GSN rate were printed. In addition, those who saved money were provided with a congratulatory message, while those with higher bills were directed to the Summer Solutions website for money saving tips.

\section{Website}

A website was created and hosted by HMG to provide basic information about the pilot, including a detailed description of the pilot and links to SMUD rebate program information. Participants were first notified of the website in the Recruitment Letter. The website address was also provided in emails sent to participants, was printed at the bottom of the CPP rate magnet (discussed below), and printed on the bills of CPP participants who did not save money that month.

\section{Other Program Materials}

Several items were distributed to participants before the experimental tariffs went into effect in June. Each business received a packet, tailored for their particular business type, with information about conserving energy usage.

A single summary page included advice for thermostat settings, solar shading and lighting fixtures, plus the address of a SMUD website listing contractors and rebates.

All participants on the CPP tariff received a magnet that summarized the rates by hour of the day, day of the week, and during events ( Figure 7).

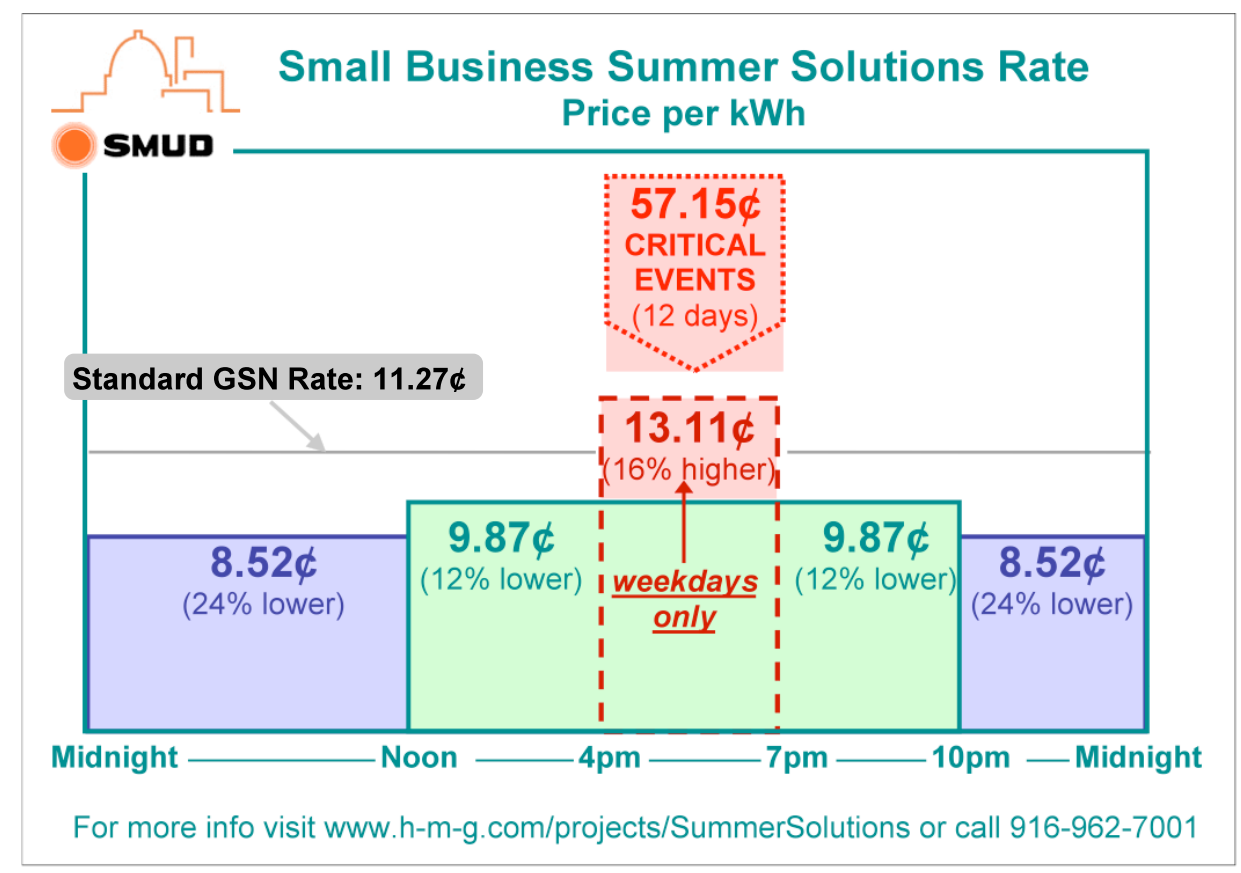

Figure 7. Magnet given to each CPP participant

\section{Event Emails}


After each event, or group of consecutive events, the research team sent emails to all 64 participants with email addresses. This email served two purposes: (1) to send a link reminding participants to respond to the online event survey, and (2) to remind participants of actions that could be taken during events.

\section{Bills}

Two different bill strategies were instituted for the two different tariff options. For the ACC option, customers received their standard SMUD bill with a new line indicating the $\$ 5$ or $\$ 10$ Summer Solutions payment, for $2^{\circ}$ and $4^{\circ}$ ACC offsets, respectively. For the CPP option, participants were sent the standard GSN bill plus a separate sheet that outlined how the CPP rate reduced or increased the amount they owed.

\subsubsection{Thermostat Installation}

We began installations of thermostats in March 2008 and completed all installations before June 2008. This allowed participants at least one month to become accustomed to the new thermostat before the first event on June 26, 2008.

A maximum of two thermostats were installed at each participant site. Customers having more than one air conditioning unit or more than two zones were discouraged from participating in the ACC program. A few of these customers (restaurants) were eventually recruited, however, due to response rates being lower than expected. Customers with more than two thermostats were welcome to participate in the CPP rate, but only one thermostat was installed.

A licensed HVAC contractor accompanied by an HMG staff member visited each site to install the thermostat hardware. The replacement thermostat was located in place of the existing one, and the connections to the air conditioning unit were as the original. Before installation, the existing thermostat wiring was photographed. After installation, the new thermostat wiring was also photographed. In this way, we had a record of the installation process at each site.

An initial functional test was carried out prior to replacement to ensure correct and safe operation of the existing installation. When this initial test failed, further work at the site was suspended until corrective measures were complete. In particular instances, the heating element of the HVAC system was not operational. Participants were notified and, in each case, agreed to continue with the installation. Following thermostat installation, a similar test was carried out to ensure full operation.

On completing installation and testing, HMG worked with the customer to program the thermostat as desired, and provided a brief tour of the thermostat programming options. Each participant received an instruction manual for the thermostat and phone numbers to get help or further information.

\subsubsection{Spring Survey}

The 70-question Spring Survey was administered in person to all participants, generally at the time of installation of the Summer Solutions thermostat. If the participant did not have a 
thermostat installed, the business was still visited and the survey conducted in person.

Responses were recorded directly into an Access database on a portable laptop computer taken to each site. In all, 79 surveys were conducted, although only 78 of these ultimately participated in the pilot. A complete list of the questions on the Spring Survey is provided in Appendix B.

\subsection{Summer 2008 Field Study}

\subsubsection{Event Schedule}

There was one test event on June 16, followed by 12 actual events called over the course of the summer (Table 8). No events were called on Mondays, mainly because a one-day advance notification would fall on a Sunday.

Table 8. Schedule of events for the 2008 Summer Solutions Pilot

\begin{tabular}{cclr}
\hline Event \# & Date & Day & Hi Temp \\
\hline 1 & $6 / 26 / 2008$ & Thu & 87.7 \\
2 & $7 / 8 / 2008$ & Tue & 106.7 \\
3 & $7 / 9 / 2008$ & Wed & 106.6 \\
4 & $7 / 18 / 2008$ & Fri & 96.7 \\
\hline 5 & $7 / 23 / 2008$ & Wed & 95.3 \\
6 & $7 / 24 / 2008$ & Thu & 96.3 \\
\hline 7 & $8 / 7 / 2008$ & Thu & 91.9 \\
\hline 8 & $8 / 13 / 2008$ & Wed & 102.4 \\
9 & $8 / 15 / 2008$ & Fri & 102.3 \\
\hline 10 & $8 / 25 / 2008$ & Tue & 94.7 \\
11 & $8 / 29 / 2008$ & Fri & 103.8 \\
\hline 12 & $9 / 5 / 2008$ & Fri & 100.7 \\
\hline
\end{tabular}

\subsubsection{Event Procedure}

The goal for this program was to call 12 events, roughly evenly spaced across the temperature range between 90 and 110, based on temperature forecasts from the National Weather Service. The following sections describe the procedures followed for each event.

\section{Pre-Event Days}

Once SMUD and HMG agreed to call an event, several actions needed to take place before 4 p.m. on the day before the event.

Emails were sent to all participants with working email addresses, notifying them of the event scheduled for the following day. Separate emails with slightly different messages were sent to the CPP and ACC groups. Both emails indicated that the following day would be an event day 
for the Small Commercial Summer Solutions Program. Participants were asked to reduce electricity use as much as possible between 4 and 7 p.m. to help with the high peak electrical demand forecast for the following day. Those with a Summer Solutions thermostat were reminded that it should already be programmed to respond to the event. Those without were asked to consider manually increasing their thermostat setpoints by a couple of degrees during the 4 to 7 p.m. peak. Other actions suggested for the events included turning off or dimming lights, and avoiding the use of other high-power devices where possible.

In addition to the email notification, text messages were sent to all thermostats, announcing the day, date and time of the planned event, while participants without email or thermostats were phoned or sent cell phone text messages.

\section{Event Days}

To signal the communicating thermostats, one event per Program Group was created on the custom-made control website. Although the technology allows for events to occur at any time for any duration specified, SMUD requested that all events be scheduled to run from 4 p.m. to 7 p.m.

Prior to sending each event signal, a test thermostat at HMG was set to receive the signal for each group, to ensure via firsthand experience that the event notification system was sent correctly. Thus, event creation proceeded as follows.

- CPP: Group 2

- Change the HMG test thermostat to Group 2

- Create Price event: Tier 4 - Critical Peak

- $\quad 2^{\circ}$ ACC: Group 3

- Change the HMG test thermostat to Group 3

- Create Change Temp event: add 2 degrees

- $4^{\circ}$ ACC: Group 4

- Change the HMG test thermostat to Group 4

- Create Change Temp event: add 4 degrees

Sending the events twice - once in the morning, and then again around noon - helped to ensure that the participants received the signal.

On receiving the signal, the thermostat displays flashed a warning of the upcoming event. At the onset of the event, the display flashed a message that an event was in progress. Warning and event messages contained specific information about the timing and duration of each event, and remained on the screen until acknowledged by the participant through a button press.

Participants also had the opportunity to receive event notification by email or phone call, which was of particular import for participants that opted out of thermostat installation.

\section{Post-Events Days}

Follow up emails were sent to all participants with email addresses. The emails thanked participants for their efforts, contained a link to the Event Survey (see below), and directed them to contact the HMG support team if they had any trouble. 


\subsubsection{Event Surveys}

The Event Survey was administered online. After each event or series of events, an email containing a link to the survey and a request for their help in filling it out was sent to all participants with an email address. Participants that lacked email or an Internet connection were phoned personally, and their responses marked for them in the online form. A complete list of the questions on the Event Survey is provided in Appendix B.

Although there were 12 events over the course of the study, there were only 10 Event Surveys because of two sets of events scheduled back-to-back (see Table 8). At these times only one request for an event survey was sent out for the two events.

There were 76 participants that completed the pilot, and each one responded to at least one event survey (Figure 8). At the end of the summer, a total of over 200 event surveys had been submitted.

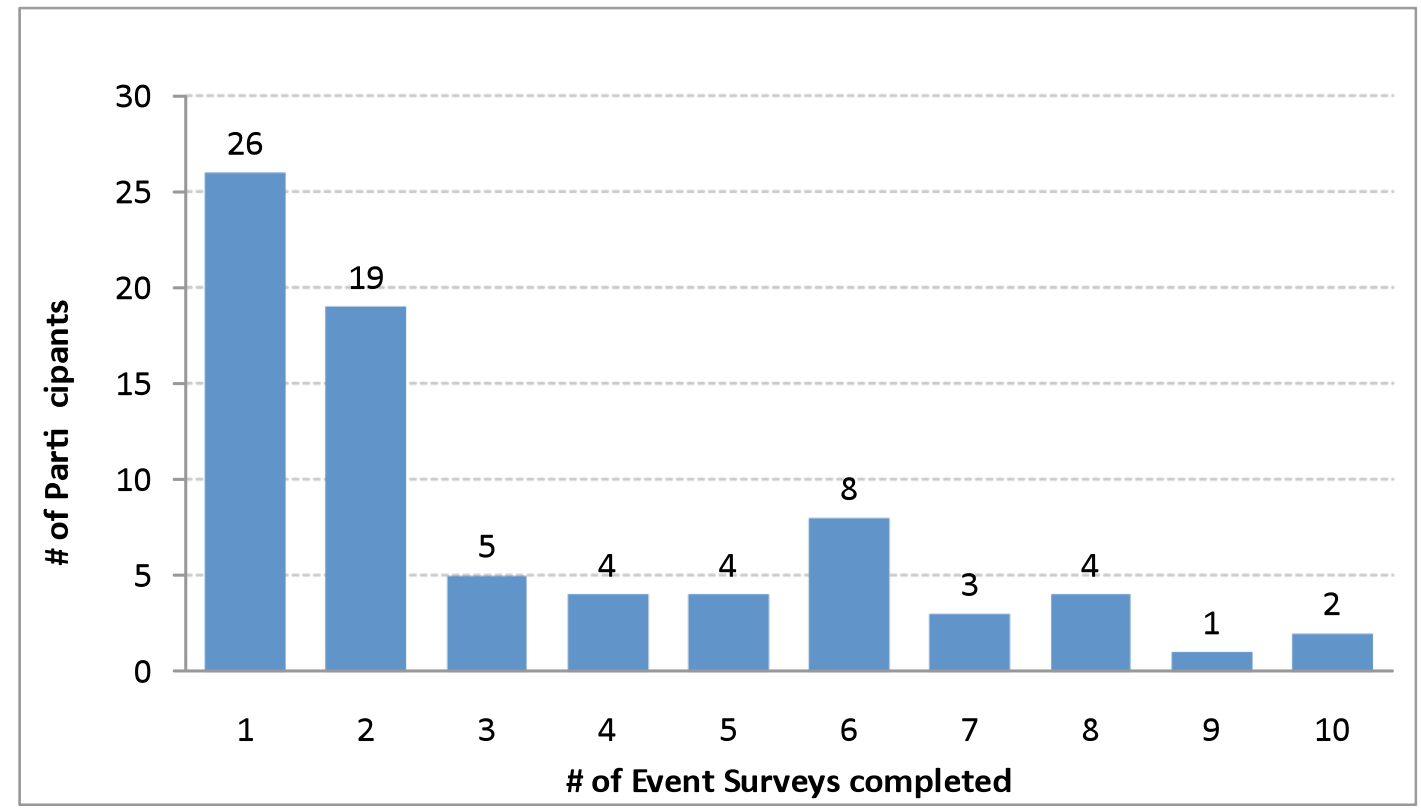

Figure 8. Number of event surveys completed by participants

\subsubsection{Fall Survey}

At the end of October, participants were emailed or phoned reminding them to complete the Fall Survey, which focused on their perceptions of the summer pilot. Given that the second \$60 incentive payment was contingent on completion of the survey, this survey had a very high completion rate: 75 out of the remaining 76 participants completed the Fall Survey. Most participants completed the online version of the survey, while those without access to the Internet were surveyed in person. A complete list of the questions on the Fall Survey is provided in Appendix B. 


\subsubsection{Decommissioning}

This pilot began with 78 participants and 71 thermostats with loggers. At the end of the study, there were 76 participants and 69 thermostats and loggers in the field. Of the 69 loggers in the field, 62 functioned properly throughout the entire summer (Table 9).

Table 9. Installed thermostats and loggers

\begin{tabular}{|l|c|c|c|}
\hline & $\begin{array}{c}\text { In place by } \\
\text { June 1, 2008 }\end{array}$ & $\begin{array}{c}\text { Active thru } \\
\text { Sept 31, 2008 }\end{array}$ & $\%$ Change \\
\hline Participants & 78 & 76 & $-3.8 \%$ \\
\hline Thermostats & 71 & 69 & $-2.8 \%$ \\
\hline Loggers & 71 & 62 & $-12.7 \%$ \\
\hline
\end{tabular}

\section{Participants that did not complete the pilot}

Three businesses never completed the pilot. The first, a retail shop, signed up and went through the initial survey, but then sold the business and moved before the tariffs went into effect on June 1. A second participant, owner of another retail shop, passed away sometime in July. The third, a bar/ restaurant owner went out of business and moved towards the end of August.

\section{Logger Issues}

Two loggers had no data due to installation error (one cord missing, one memory card not fully plugged in). One was not plugged in to the RDS receiver completely. Three data loggers had missing or incomplete data seemingly due to hardware malfunction. An additional three were unplugged and/or plugged back in incorrectly before the $8^{\text {th }}$ event.

\section{Thermostat Malfunctions}

Of the thermostats installed for this pilot, only one was removed because it malfunctioned. The faulty thermostat was installed at a retail shop, who complained that the thermostat was unable to keep the business cool in the afternoons, whether or not it was an event that day. After reinstallation of their original thermostat, everything returned to normal. Despite this negative experience, the owner elected to stay on the CPP rate beyond the thermostat removal.

\section{Other Thermostat Issues}

In May, before the pilot really got under way, one restaurant requested the removal of the thermostat because it was not keeping them cool in the afternoons. After their old thermostat was reinstalled and the comfort issues were not resolved, a unit inspection revealed that their air-conditioner was old and undersized. At this point, the restaurant requested that the thermostat be reinstalled.

After the conclusion of the pilot, three retail businesses requested the removal of the thermostats. One was a pet store, who said they wanted their original thermostats reinstalled 
because they were more expensive and advanced; they had no negative things to say about the thermostats we had installed for them. One was a copy shop who was unhappy about the 6minute minimum off-time for the compressor, because the business had so many heatgenerating pieces of equipment (e.g. copiers, printers, and computers). The reason given for the third and final removal was that the staff considered the thermostat too complicated to operate - they preferred a simple on/off switch, which was how their old thermostat worked.

Two businesses also had problems operating their heat after the study concluded. After site visits by an HVAC contractor, these issues were resolved. One retail shop had an unusually old electric furnace, which required the addition of a sequencer for the new thermostat to operate the heat properly. At the other site, the thermostat was wired improperly for heat at the original installation. The contractor rewired it correctly and the problem was resolved. 


\subsection{DATA ANALYSIS AND RESULTS}

Multiple types of information were collected from study participants at several points in the project. Initially, basic characteristics for each participant were gathered during the recruitment stage. More detailed business and building information was collected through the Spring Survey. Once hardware was installed, we began logging electric meter and thermostat data every fifteen minutes. Throughout the summer, we requested that participants complete a short Event Survey, directly after each event, on how they perceived and responded to each event. At the end of the study, detailed participant perceptions of the program were documented in their Fall Survey answers. A summary of these and other datasets and sources utilized for this study is presented in Table 10.

Table 10. Summary of data collected for this project

\begin{tabular}{|c|c|c|}
\hline Source & Data collected & Use(s) \\
\hline $\begin{array}{l}\text { SMUD } \\
\text { customer } \\
\text { database }\end{array}$ & $\begin{array}{l}\text { - } \quad \text { Contact information } \\
\text { - } \quad \text { Monthly billing data }\end{array}$ & $\begin{array}{l}\text { - } \quad \text { Market assessment and segmentation } \\
\text { - } \quad \text { Recruitment and screening } \\
\text { - Monthly load impact analysis }\end{array}$ \\
\hline \multirow[t]{2}{*}{$\begin{array}{l}\text { Spring } \\
\text { Survey }\end{array}$} & $\begin{array}{l}\text { - } \quad \text { Business operations } \\
\text { Building \& equipment } \\
\text { characteristics }\end{array}$ & - Refine segmentation \& screening \\
\hline & - Pre-pilot load shifting behavior & - $\quad$ Pre/post behavior analysis \\
\hline $\begin{array}{l}\text { Event } \\
\text { Surveys }\end{array}$ & - Event behavior and comfort & $\begin{array}{l}\text { - } \quad \text { Customer education \& encouragement } \\
\text { - } \quad \text { Participant problem resolution }\end{array}$ \\
\hline \multirow{3}{*}{$\begin{array}{l}\text { Thermostat } \\
\text { Logger }\end{array}$} & - $\quad$ Thermostat set points & - $\quad$ Participant behavior vis-à-vis AC \\
\hline & $\begin{array}{ll}\text { - } & \text { Indoor temperature } \\
\text { - } \quad \text { Compressor status }\end{array}$ & $\begin{array}{l}\text { - AC unit behavior } \\
\text { - Diagnostics }\end{array}$ \\
\hline & - Messages from utility & - Event signal receipt confirmation \\
\hline CPP bills & $\begin{array}{l}\text { Monthly electricity charges on } \\
\text { CPP and GSN rates }\end{array}$ & - Billing analysis for CPP participants \\
\hline Interval Meter & $\begin{array}{l}\text { - } 15 \text {-minute whole house } \\
\text { electricity usage }\end{array}$ & $\begin{array}{l}\text { - } \quad \text { Critical Peak Pricing billing (SMUD) } \\
\text { - Hourly load impact analysis }\end{array}$ \\
\hline CIMIS & $\begin{array}{l}\text { - Outdoor ambient temperatures } \\
\text { for Fair Oaks, California }\end{array}$ & $\begin{array}{l}\text { - Event scheduling } \\
\text { - Hourly load impact analysis }\end{array}$ \\
\hline \multirow[t]{2}{*}{ Fall Survey } & - Satisfaction & $\begin{array}{ll} & \text {...with new tariff } \\
\text { - } & \text {...with new thermostat } \\
\text { - } & \text {...with program in general }\end{array}$ \\
\hline & $\begin{array}{l}\text { - } \quad \text { Load shifting behaviors } \\
\text { - Event behaviors }\end{array}$ & - Pre/post behavior analysis \\
\hline
\end{tabular}

Analysis of both quantitative and qualitative data focused around segmentation of data by building and program type. The following sections describe the data analysis and results. 


\subsection{Thermostat Logger Data}

Throughout the pilot, a logger on each thermostat collected data every fifteen minutes from the thermostat. Each record included a timestamp plus actual setpoints, indoor temperature, compressor status, reception of utility messages and event setting overrides. These data allowed for analysis of signal reception, event override, and setpoint activity with accompanying indoor temperatures and compressor status.

\subsubsection{Signal Reception Analysis}

Prior to each event day, information about the upcoming event was broadcast via RDS, so participants with thermostats would receive a notification of the event on the thermostat display. On average, $73 \%$ of the event signals sent were received and acted upon by the 67 communicating thermostats in the field (Figure 9). This RDS reception rate is expected to increase in the near future as the next version of RDS receivers enters the market.

About half of the signaling problems were resolved by the fourth event, however, loss of logger data, which was not related to RDS reception, increased slightly after the sixth event.

$$
\square \text { no } \log
$$

$\square$ signal not received

$\square$ signal received

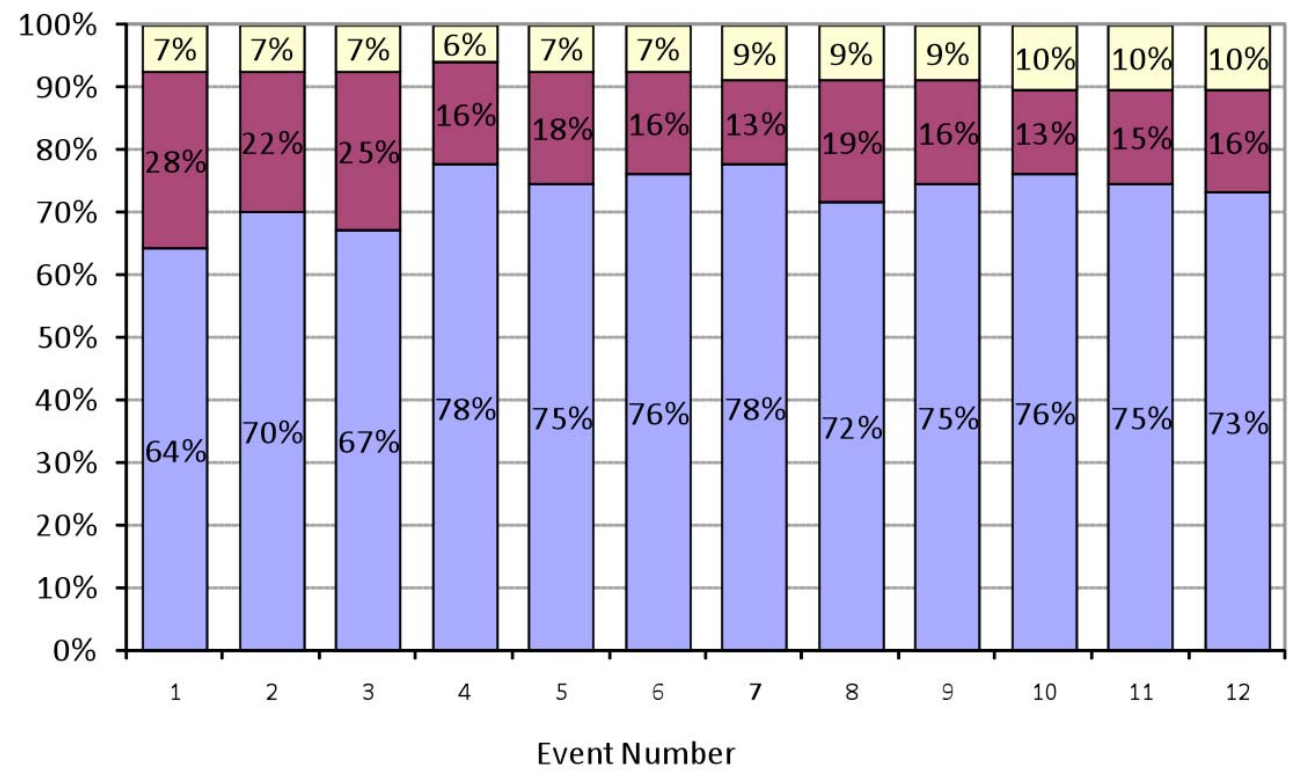

Figure 9. Percentage of event signals received and acted upon, by event number

Figure 10 shows that about one-third of the 67 thermostats received all 12 events, while about three-quarters received at least 8 of the 12 event signals. Eight thermostats $(12 \%)$ received no event signals at all. 


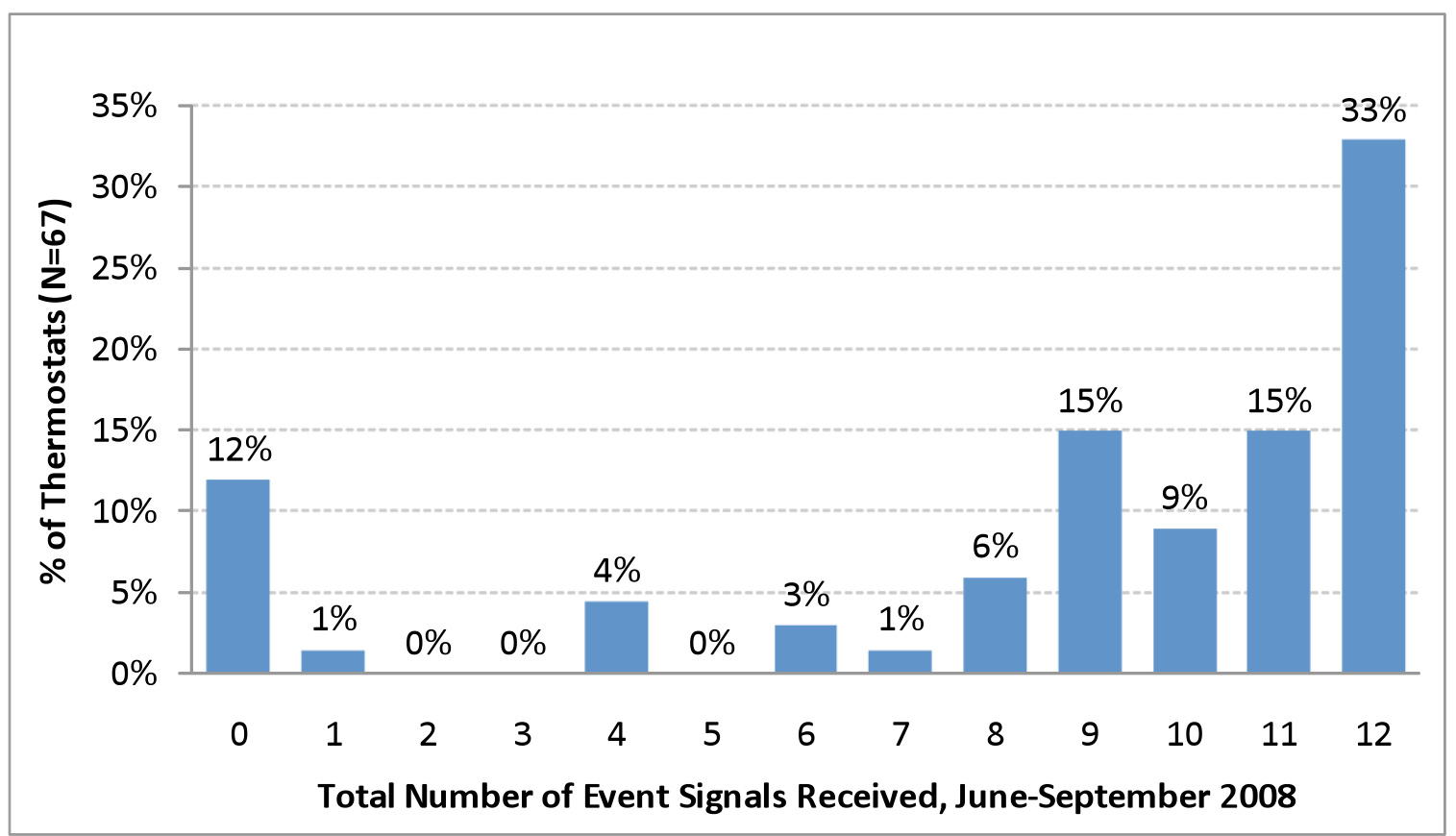

Figure 10. Percentage of thermostats receiving no events signals, all 12 event signals, and everything in between

\subsubsection{Override Analysis}

Overall, about $5 \%$ of events were overridden by participants, meaning that after a thermostat responded to an event signal, one of the occupants of the building decreased the event setpoint by one or more degrees (Table 11).

Table 11. Percent of event signals overridden, by business type and program choice

\begin{tabular}{lrrr|r}
\hline Business Type & $2^{\circ}$ ACC & $4^{\circ}$ ACC & CPP & All \\
\hline Office & $8 \%$ & $3 \%$ & $5 \%$ & $4 \%$ \\
\hline Restaurant & $0 \%$ & N/A & $11 \%$ & $4 \%$ \\
\hline Retail & $6 \%$ & $2 \%$ & $9 \%$ & $7 \%$ \\
\hline All & $3 \%$ & $3 \%$ & $7 \%$ & $5 \%$ \\
\hline
\end{tabular}

As expected, fewer overrides occurred in the ACC programs, because these participants were told that overrides were not allowed. Although CPP participants were told they could override their event settings at any time, only $7 \%$ of CPP events swayed participants to modify the event setpoint. 


\subsubsection{Setpoint and Compressor Analysis}

Among other things, thermostat loggers recorded setpoints and compressor status. This section compares average thermostat setpoints along with the corresponding status of participating airconditioning compressor units on event days and non-event days. For all graphs provided in this section, actual setpoints are plotted, while compressor status is weather-normalized using the regression model shown in Equation 1.

$$
\begin{aligned}
\operatorname{Pr}\left(\text { Compressor }_{i}=1\right)= & \operatorname{logit}^{-1}\left(\alpha+\sum_{j=1}^{23}\left(\beta_{j}^{\text {Hour }} \cdot \text { Hour }_{j}+\beta_{j}^{\text {EventHour }} \cdot \text { Event Hour }_{j}\right)+\right. \\
& \sum_{k=1}^{3} \beta_{k}^{\text {Month }} \cdot \text { Mont }_{k}+\sum_{l=1}^{4} \beta_{l}^{\text {Day }} \cdot \text { Day }_{l}+ \\
& \left.\beta^{C D H} \cdot C D H+\beta^{\text {dayCDH }} \cdot \text { DayCDH }\right)
\end{aligned}
$$

Where Compressor ${ }_{\mathrm{i}}$ is a dummy variable equal to 1 if the compressor is running for hour $\mathrm{i}$ and 0 otherwise, is the intercept term, and the 's are the estimated parameters, and:

- Hour is a set of 23 dummy variables for hour of the day for non-event days,

- EventHour is a set of 23 dummy variables for hour of the day for event days,

- Month is a set of three dummy variables for month, and

- Day is a set of four dummy variables for day of the week.

The two other variables are calculated from hourly weather data, where:

- $\mathrm{CDH}$ is the number of cooling degree hours (base 75) for hour $\mathrm{i}$

- DayCDH is the total cooling degree hours for the day 
Figure 11 shows average setpoints and weather normalized compressor status on event and non-event days for participating offices. Average setpoints on non-event days show a smooth transition from roughly $85^{\circ}$ at night to about $75^{\circ}$ during work hours. On event days, a clear shift takes place. Event day setpoints are about $4^{\circ}$ lower than non-event setpoints between 8 a.m. and 4 p.m., indicating precooling on event days. Average setpoints then increase from $75^{\circ}$ to over $80^{\circ}$ at 4 p.m., and then again to more than $85^{\circ}$ at 5 p.m., when most offices close for the evening.

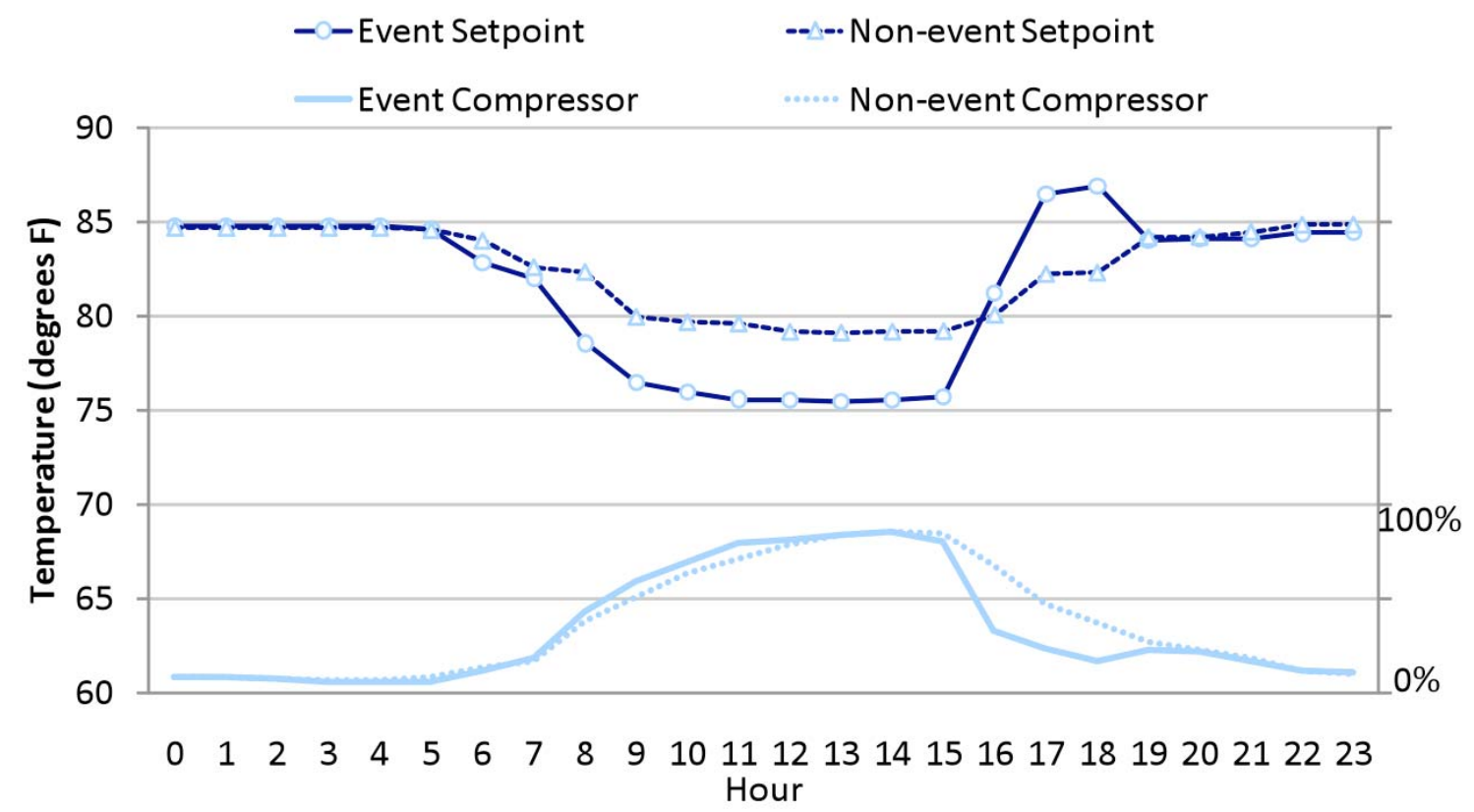

Figure 11. Event and non-event setpoints, with weather-normalized compressor status, offices

Compressor status, also shown in Figure 11, should be compared to the right axis labels, where $100 \%$ indicates that all of the compressors in the sample are running, and $0 \%$ indicates that none of the compressors are running. Here, the effects of precooling on event days can barely be seen in the morning hours. In contrast, the event hours - indicated by the shading between 4 and 7 p.m. - show a marked decrease in compressor activity. 
Logger data for restaurants paint a slightly different picture (Figure 12). Restaurants, like offices, attempt to precool on event days, lowering setpoints by as much as $6^{\circ}$ between 10 a.m. and 4 p.m. However, the precooling has no effect on the compressors, which are running continuously under both scenarios. Following this "precooling," loggers show an event offset of $4^{\circ}$ at 4 p.m., however, again the compressors are unaffected. This provides evidence that (1) the restaurants in our participant population have undersized AC units, and (2) building spaces with undersized $\mathrm{AC}$ units are unlikely to provide load drop during demand response events.

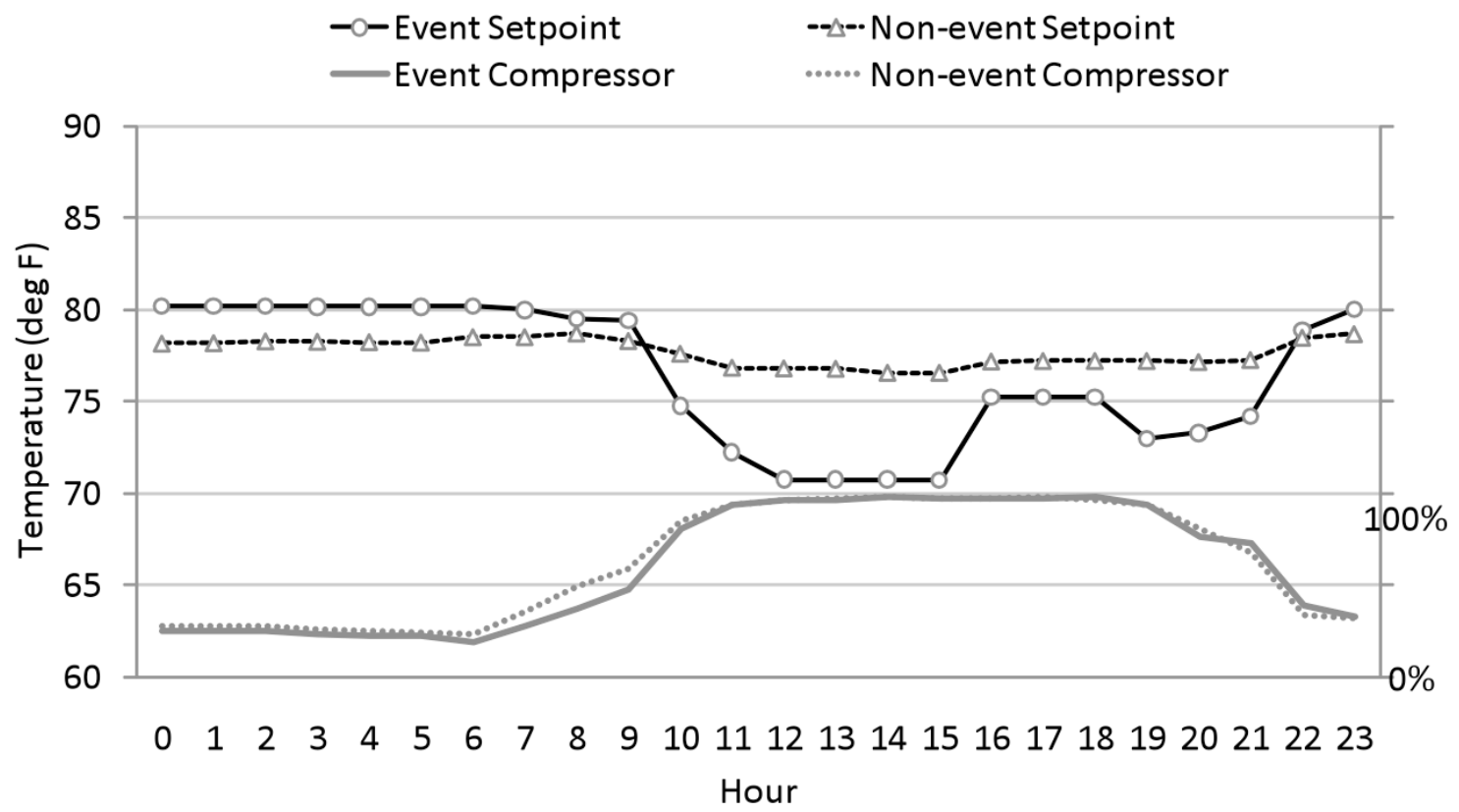

Figure 12. Event and non-event setpoints, with weather-normalized compressor status, restaurants 
The plot of logger data for retail (Figure 13) looks very similar to that of offices (Figure 11). Precooling to $75^{\circ}$ begins at about 8 a.m. on event days, and continues to 4 p.m., when setpoints increase by about $5^{\circ}$ on average to $80^{\circ}$, and then to $85^{\circ}$ at 6 p.m. The resulting compressor status is also similar. Again, the effects of precooling on event days can barely be seen in the morning hours, while the effects of the event offset are clearly visible between 4 and 7 p.m.

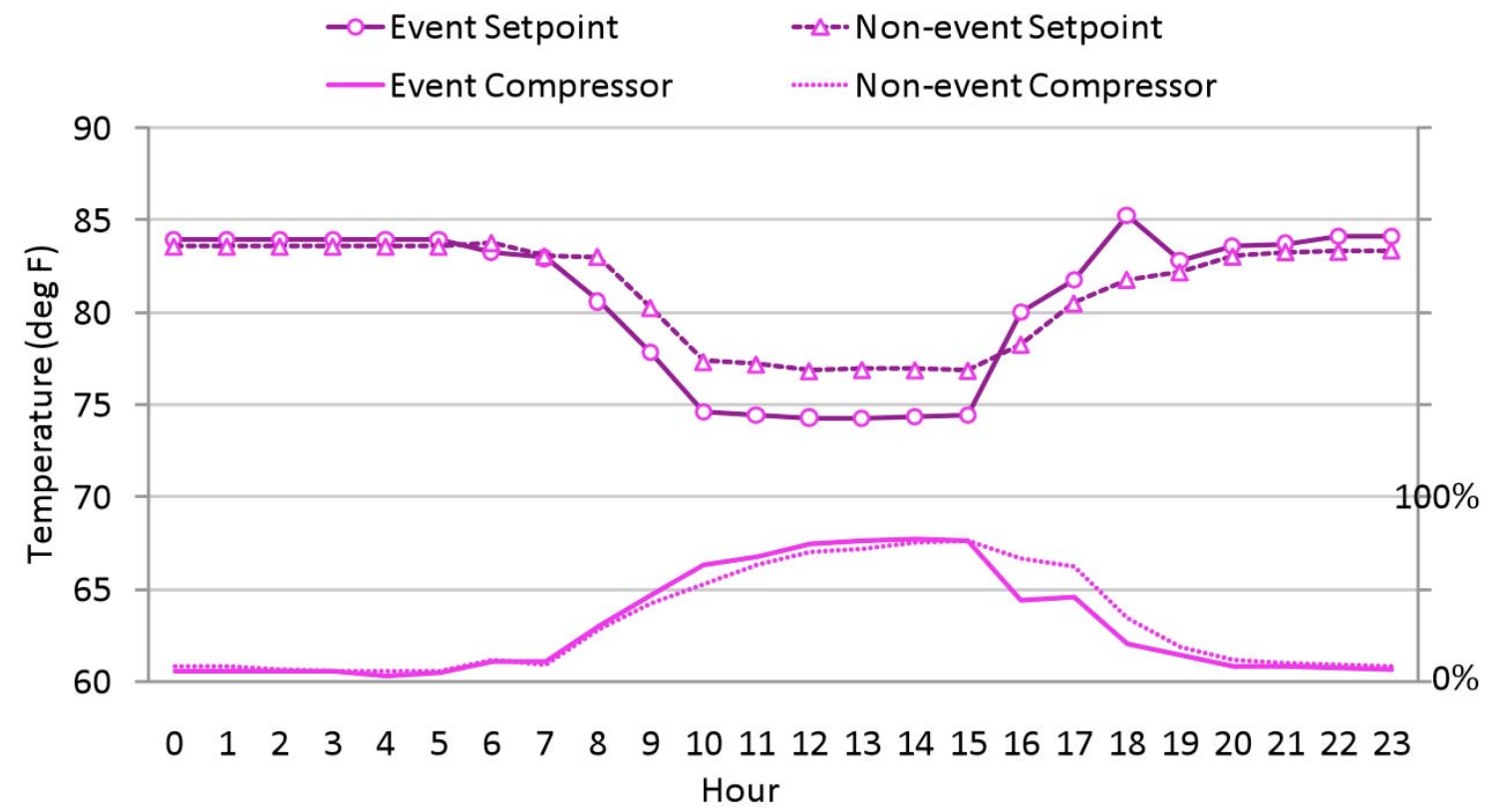

Figure 13. Event and non-event setpoints, with weather-normalized compressor status, retail 


\subsection{Hourly Load Impacts on Event Days}

The interval meters installed on participant buildings recorded load every fifteen minutes for the purpose of participant load impact estimation and CPP billing. For simplicity, this data was aggregated by hour prior to analysis.

\subsubsection{Hourly Load Impact Regression Model}

The model used to analyze the hourly load data is a linear autoregressive model, which estimates the hourly load (in kWh per hour) for an average customer, fit using the maximum likelihood method with a lag of 1 . The model controls for several important factors: hour of the day, day of the week, month, cooling degree hours for the hour in question, and total cooling degree hours for the day (Equation 1). Because the model uses the load shape of each customer on non-event days as the baseline load, a control group is not necessary for estimation of $\mathrm{kW}$ load impacts.

$$
\begin{aligned}
Q_{i}= & \alpha+\beta^{\text {lag }_{1}} \cdot Q_{\text {lag }_{1}}+\sum_{j=1}^{23}\left(\beta_{j}^{\text {Hour }} \cdot \text { Hour }_{j}+\beta_{j}^{\text {EventHour }} \cdot \text { EventHour }_{j}\right)+ \\
& \sum_{k=1}^{3} \beta_{k}^{\text {Month }} \cdot \text { Month } \\
& \beta^{C D H} \cdot \sum_{l=1}^{4} \beta_{l}^{\text {Day }} \cdot \text { Day }+ \\
& \text { D }+\beta^{\text {DayCDH }} \cdot \text { DayCDH }+\epsilon_{i}
\end{aligned}
$$

In Equation 2, $\mathrm{Q}_{\mathrm{i}}$ is the $\mathrm{kWh} / \mathrm{hr}$ for hour i for an average customer, is the intercept term, and the 's are the estimated parameters. Also:

- $Q_{\text {lag1 }}$ is the $\mathrm{kWh} / \mathrm{hr}$ load for the previous hour,

- Hour is a set of 23 dummy variables for hour of the day for non-event days,

- EventHour is a set of 23 dummy variables for hour of the day for event days,

- Month is a set of three dummy variables for month, and

- Day is a set of four dummy variables for day of the week.

The two other variables, are calculated from weather data, where:

- $\quad C D H$ is the number of cooling degree hours (base 75) for hour $i$, and

- $D a y C D H$ is the total cooling degree hours for the day.

A total of fifteen models were fit to the data. First to examine the average loads for each business type, we made three models, pooling data for each business type (office, restaurant, retail). Then to look at the average loads by program, we pooled data by program $\left(2^{\circ} \mathrm{ACC}, 4^{\circ}\right.$ ACC and CPP). Finally, we made nine models to find the average response for each program within each business type. Load and impact results are presented here for a $100^{\circ}$ day with the temperature profile shown in Figure 14. 


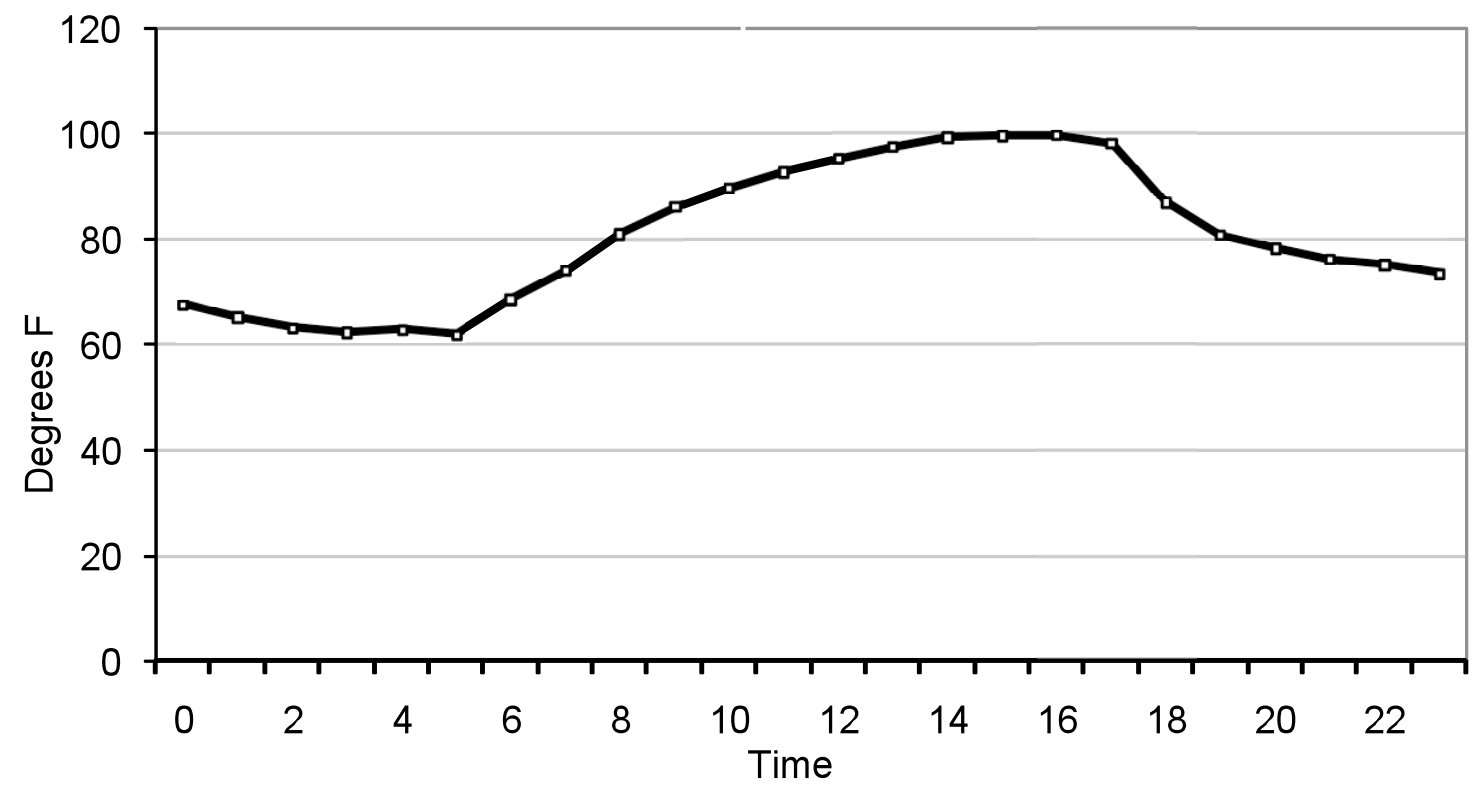

Figure 14. Temperature profile used to create load and impact results

The following sections provide the results of this model.

\subsubsection{Overall results}

Modeled savings estimates, averaged over event periods, are shown in Table 12, by business type and program choice. These results show the greatest savings $(0.76-0.81 \mathrm{kWh})$ from retail on the CPP rate and for offices and retail on a 4-degree ACC program. Good results (0.35-0.57 $\mathrm{kWh} / \mathrm{h}$ ) were also obtained for offices and retail on the 2-degree ACC program, offices on the CPP program, and restaurants on the CPP program.

Table 12. Average load drop during event periods

\begin{tabular}{|c|c|c|c|c|c|c|}
\hline \multirow[b]{2}{*}{ Office } & \multicolumn{2}{|c|}{$\begin{array}{c}\mathbf{2}^{\circ} \text { ACC } \\
(k W h / h) \quad(\% \text { of baseline })\end{array}$} & \multicolumn{2}{|c|}{$\begin{array}{c}\mathbf{4}^{\circ} \mathbf{A C C} \\
(\mathrm{kWh} / \mathrm{h}) \quad(\% \text { of baseline })\end{array}$} & \multicolumn{2}{|c|}{$\begin{array}{c}\text { CPP } \\
(k W h / h) \quad(\% \text { of baseline })\end{array}$} \\
\hline & $-0.48^{\star}$ & $-42 \%{ }^{*}$ & -0.80 & $-38 \%$ & -0.57 & $-24 \%$ \\
\hline Restaurant & -0.18 & $-1 \%$ & $-0.10^{*}$ & $-1 \%{ }^{*}$ & -0.35 & $-3 \%$ \\
\hline Retail & -0.45 & $-8 \%$ & -0.76 & $-22 \%$ & -0.81 & $-14 \%$ \\
\hline
\end{tabular}

* Only one participant in the sample 
Figure 15 shows, for each participant, the magnitude of their peak load change during event hours (y-axis) graphed against the magnitude of change in their daily usage on event days ( $x$ axis). The size of the bubble indicates the number of events for which each participant received and responded to the event notification. The color of the bubbles indicates whether the participant had installed a communicating thermostat.

The white bubbles are all the same size because these customers did not have a thermostat, and therefore received a phone call or email notifying them of each event. The smallest bubbles indicate that no event notifications were received by the thermostat - however, most of these participants were also notified by email, and so could have responded manually. The largest received all twelve event notifications.

During event hours, 66 meters recorded a reduction in load $(\mathrm{kW})$, while 14 recorded an increase in load, for an overall average load drop of $0.52 \mathrm{~kW}$ during events. On event days, 51 meters recorded a reduction in usage $(\mathrm{kWh})$, while 29 recorded an increase in usage, for an overall average of $0.74 \mathrm{kWh}$ load drop on event days. Note that the total number of meters (80) is higher than the final number of participants because there were a few businesses with two accounts that were individually metered.

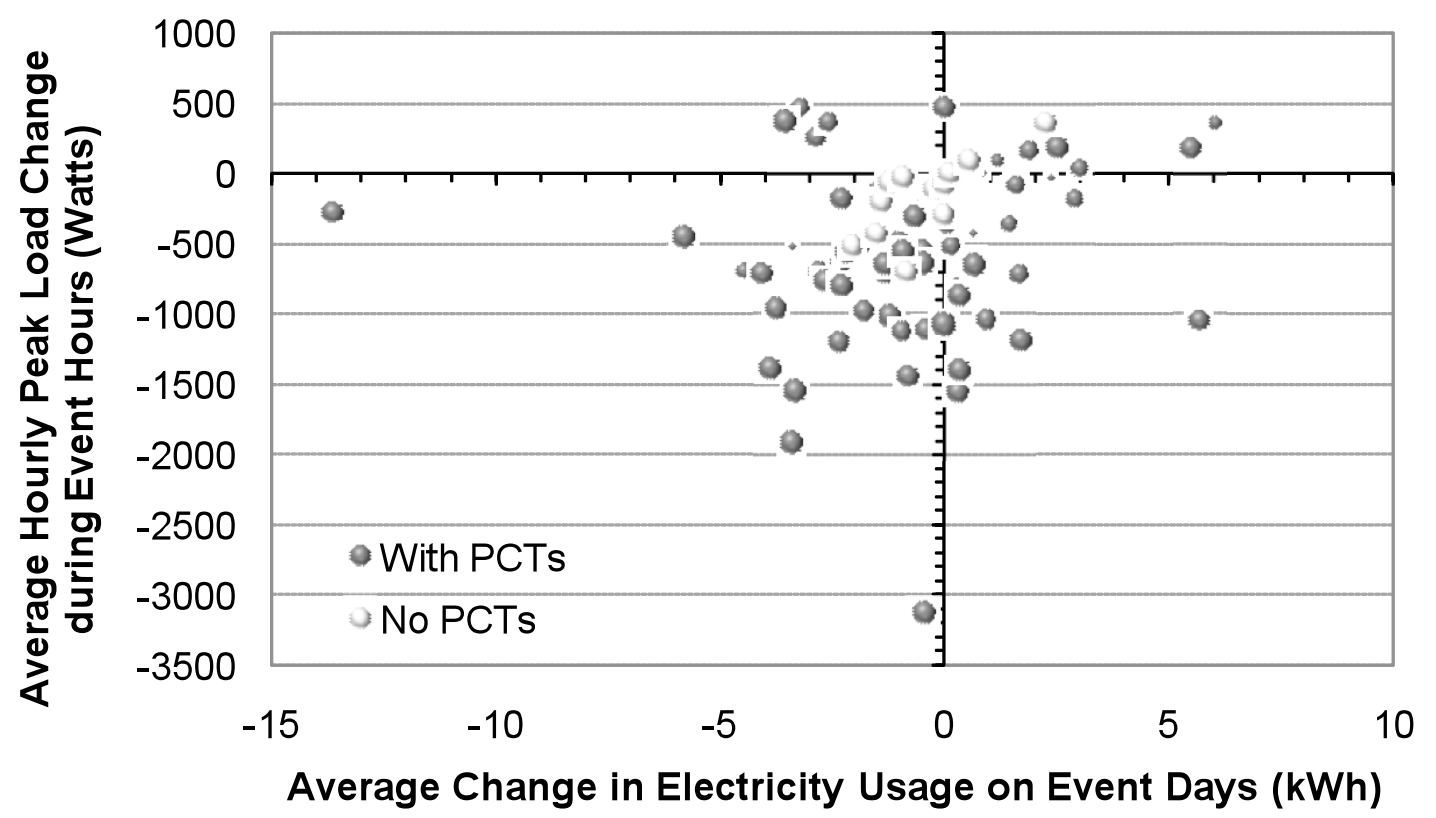

Figure 15. Total Load Change on event days, percent vs. watts

Also noteworthy is that the non-PCT participants are more densely clustered around the origin than are the PCT participants, indicating that load and usage changes were more extreme for those customers with communicating thermostats. On average, participants with PCTs dropped $0.58 \mathrm{~kW}$ during events, while those without PCTs dropped $0.16 \mathrm{~kW}$ during events. Likewise, participants with PCTs used $0.8 \mathrm{kWh}$ less on event days than on non-event days, while those without PCTs used $0.4 \mathrm{kWh}$ less on event days. 
In summary, this analysis shows that, on average, participants were able to drop load during event hours without increasing overall usage on event days, and that use of enabling technology (PCT) results in greater load and energy savings.

\subsubsection{By Business Type and Program}

The following three sections provide the results of the hourly load data analysis for offices, restaurants and retail shops. Within each section, the data analysis is provided for each of the three program types: 2- degree ACC, 4-degree ACC and CPP.

\section{Offices}

Figure 16 shows the hourly load shapes for the one office that signed up for the 2-degree ACC program. For this one participant, the graph shows a statistically significant load increase at 8 a.m. on event days, and a statistically significant load drop in the first hour of the event between 4 and 5 p.m. A significant rebound effect can also be seen at 7 p.m. following the event.

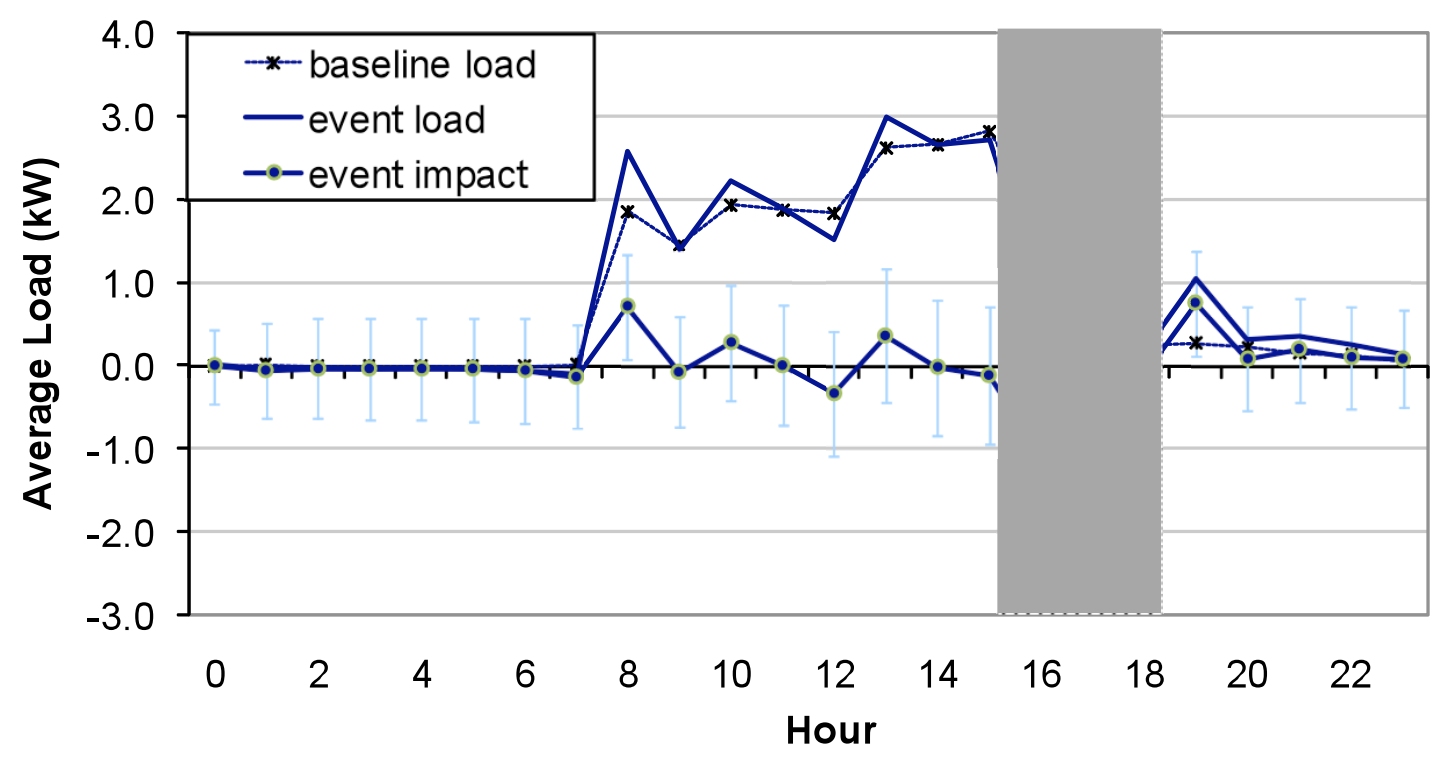

Figure 16. Average loads on event and non-event days, 2-degree office ( $N=1)$ 
Figure 17 shows the hourly load shapes for the 11 offices that signed up for the 4-degree ACC program, and Figure 18 shows the hourly load shapes for the 23 offices that signed up for the $\mathrm{CPP}$ rate. In both graphs, there is no significant load increase preceding events, and a statistically significant load drop in all three hours of the event between 4 and 7 p.m. No significant rebound effect can be seen following events.

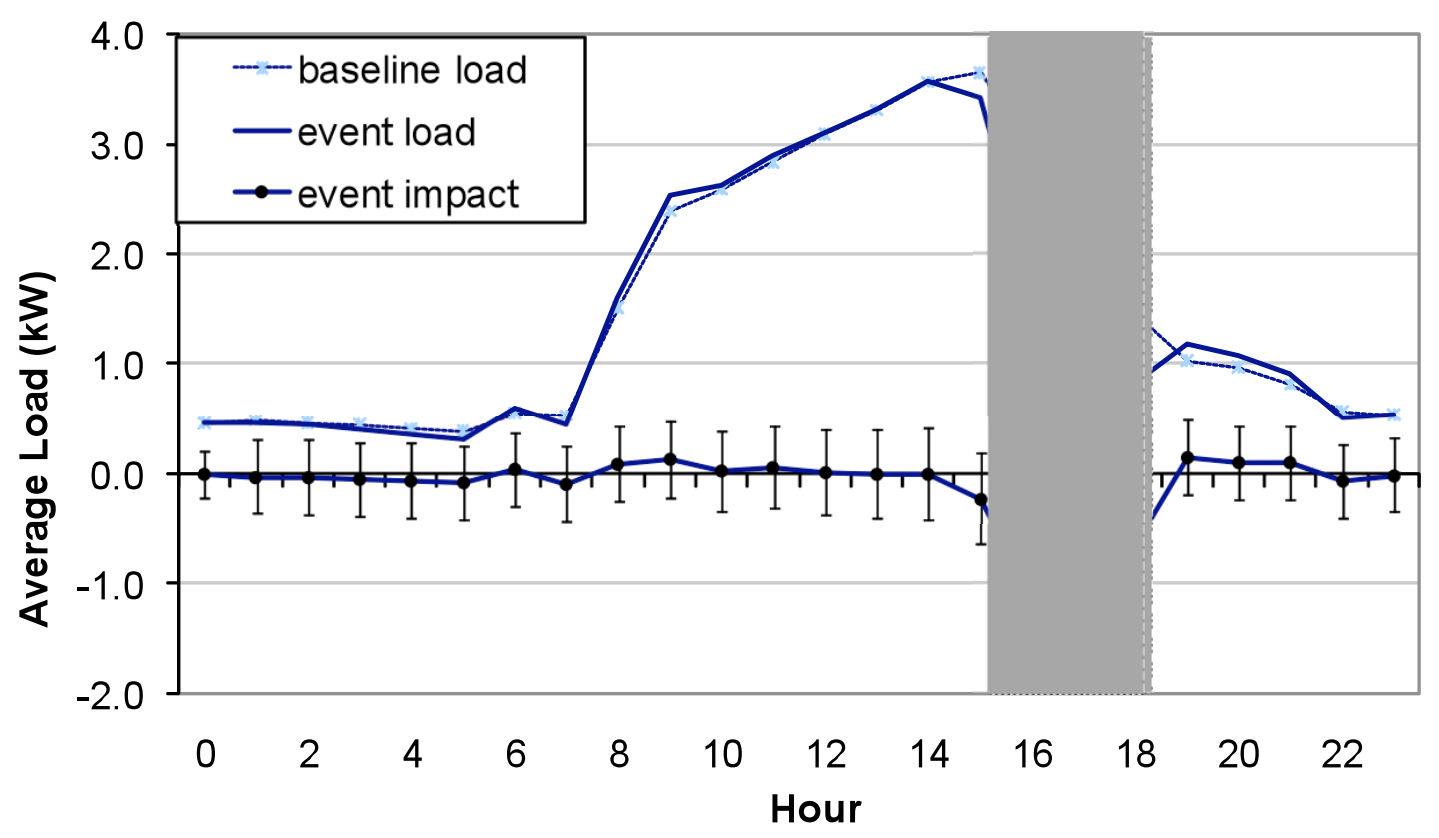

Figure 17. Average loads on event and non-event days, 4-degree office $(\mathrm{N}=11)$

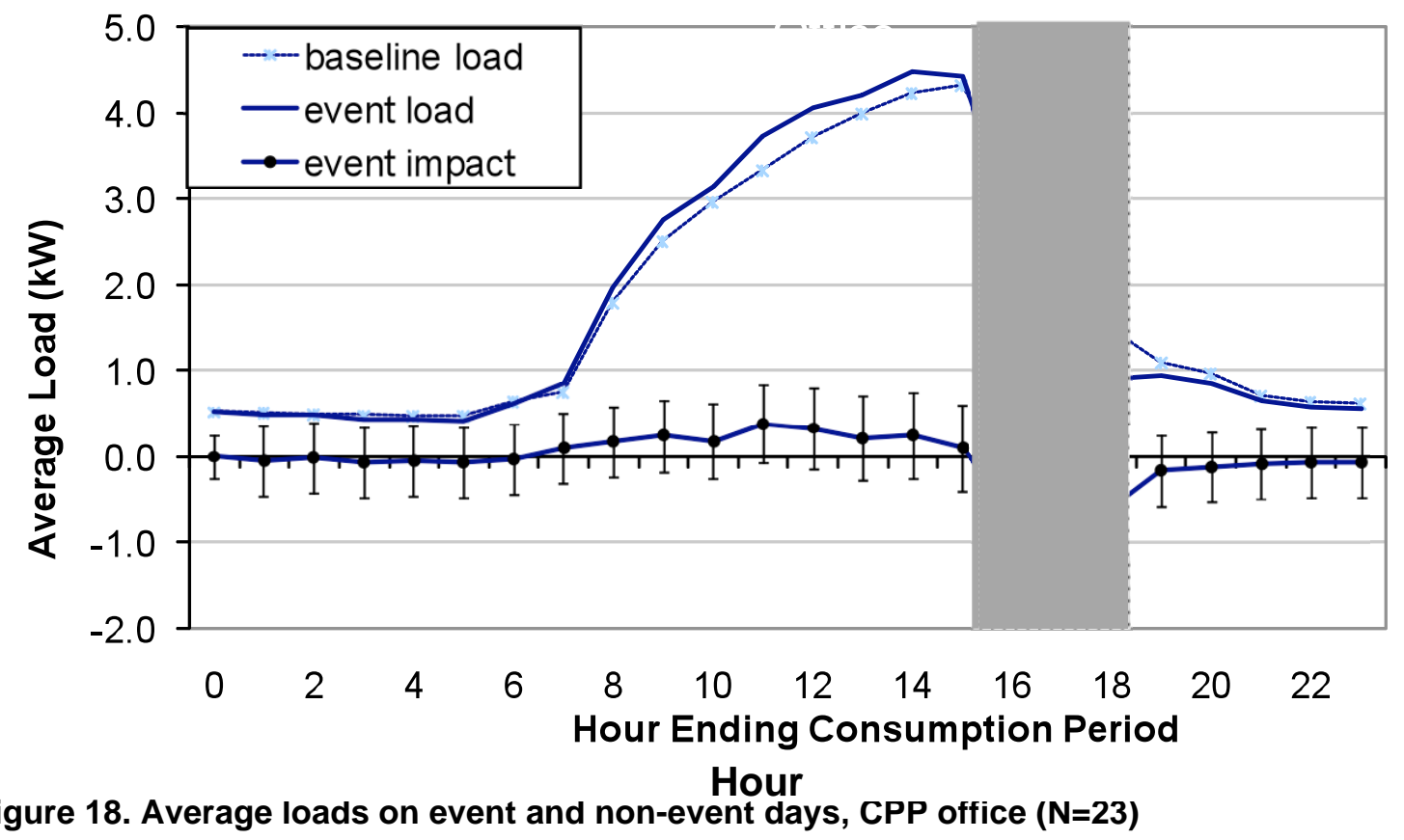




\section{Restaurants}

Figure 19 shows the hourly load shapes for the three restaurants that signed up for the 2-degree ACC program. For these participants, the graph shows a statistically significant load drop between 8 and 10 a.m. on event days, no significant load drop during events, and a significant rebound effect between 9 and 10 p.m. following events.

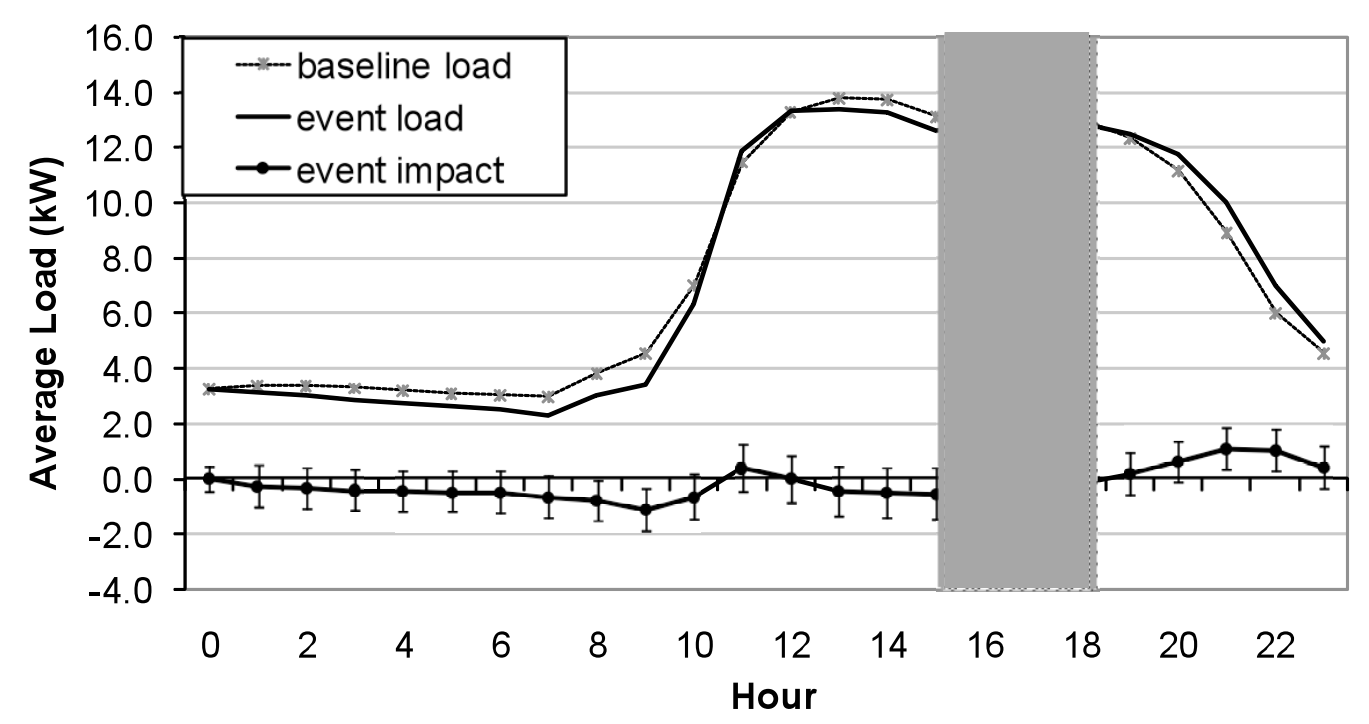

Figure 19. Average loads on event and non-event days, 2-degree restaurants ( $N=3$ )

Figure 20 shows the hourly load shapes for the one restaurant that signed up for the 4-degree ACC program, and Figure 21 shows the hourly load shapes for the 8 restaurants that signed up for the CPP rate. In both graphs, there is no significant load change in any hour of the event days. 


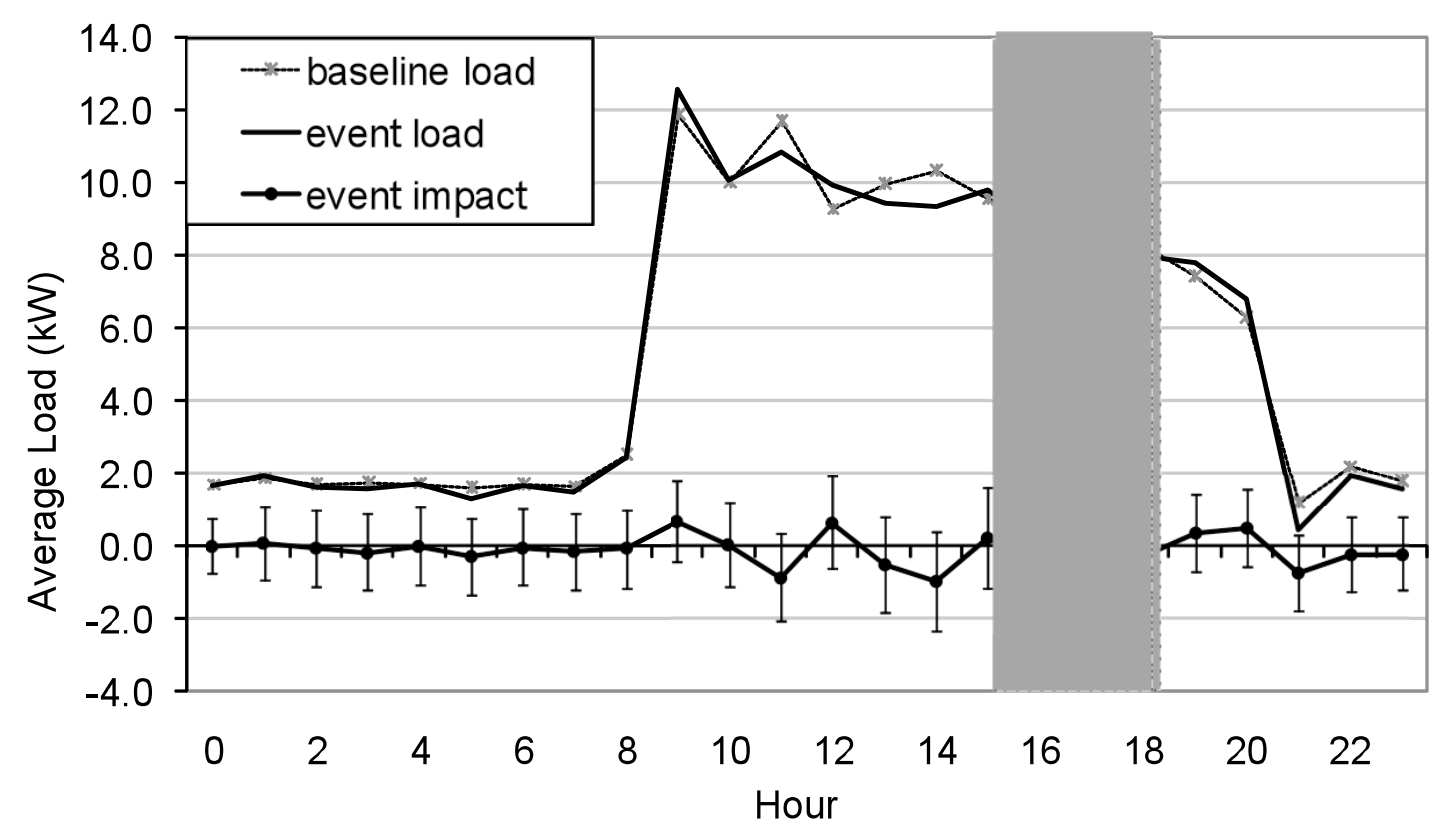

Figure 20. Average loads on event and non-event days, 4-degree restaurants $(\mathrm{N}=1)$

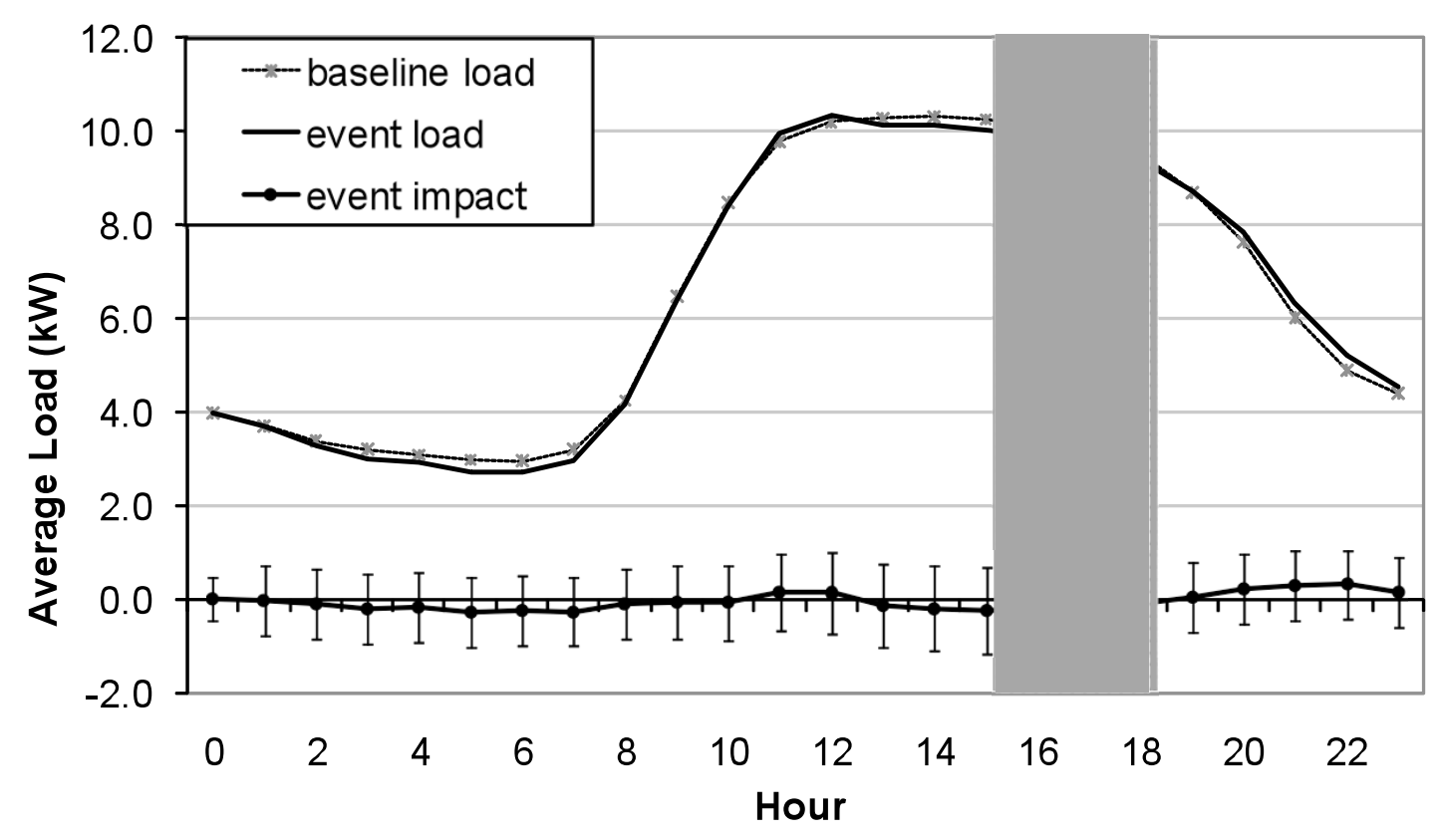

Figure 21. Average loads on event and non-event days, CPP restaurants $(\mathrm{N}=8)$ 


\section{Retail}

Figure 22 shows the hourly load shapes for the 3 retail shops that signed up for the 2-degree ACC program. For these participants, the graph shows a visible but statistically insignificant load increase in the hours directly preceding the events, and a visible but statistically insignificant load drop in the three hours of the event and beyond. No rebound effect is visible following the event.

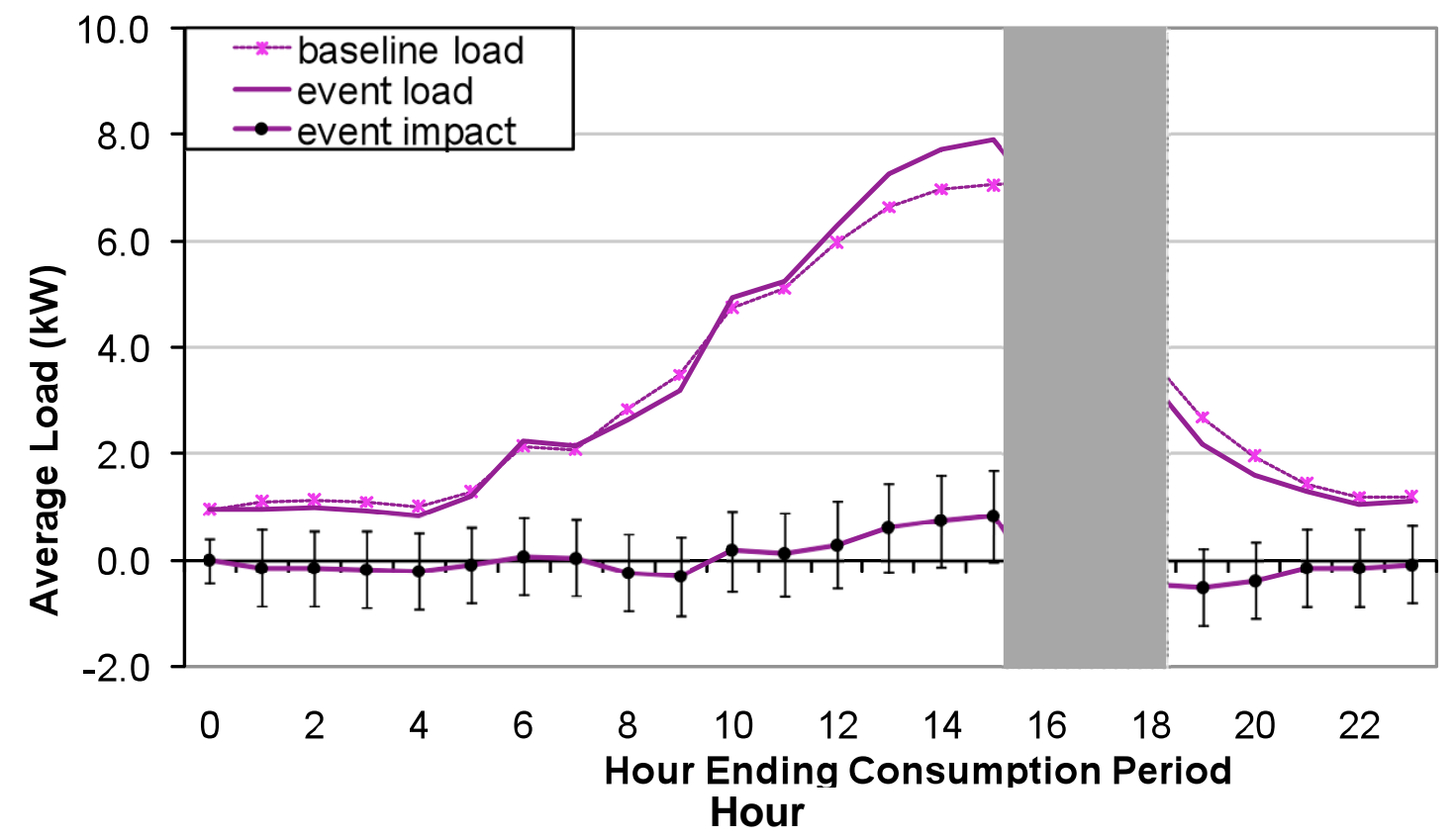

Figure 22. Average loads on event and non-event days, 2-degree retail $(\mathrm{N}=3)$

Figure 23 shows the hourly load shapes for the 8 retail shops that signed up for the 4-degree ACC program. For these participants, there is a visible but insignificant load increase preceding events, followed by a statistically significant load drop in all three hours of the event. No rebound effect can be seen following events.

Figure 24 shows the hourly load shapes for the 20 retail shops that signed up for the CPP rate. For these participants, there is a statistically significant load increase preceding events, followed by significant load drop in all three hours of the event and beyond. No rebound effect can be seen following events. 


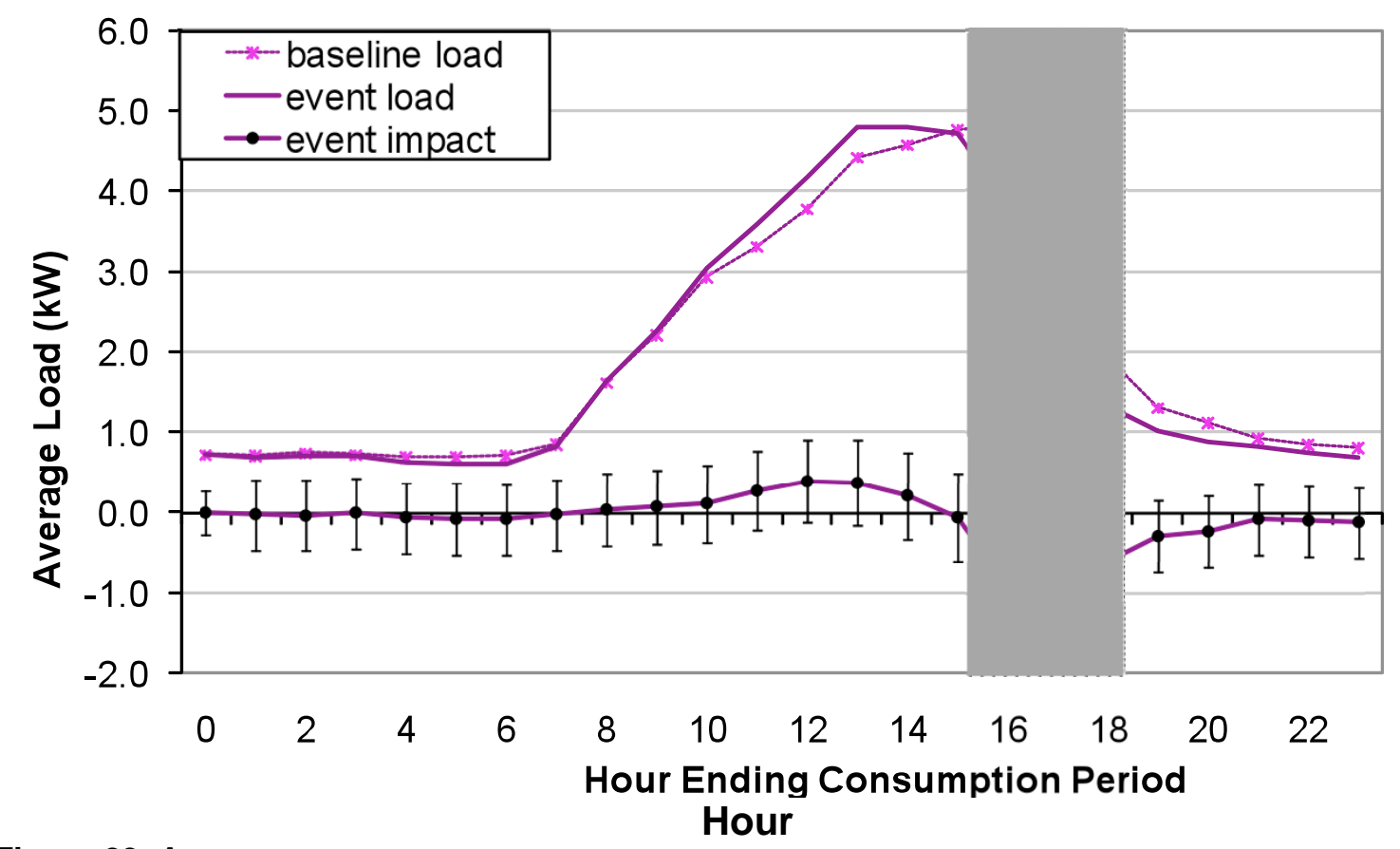

Figure 23. Average loads on event and non-event days, 4-degree retail $(\mathrm{N}=8)$

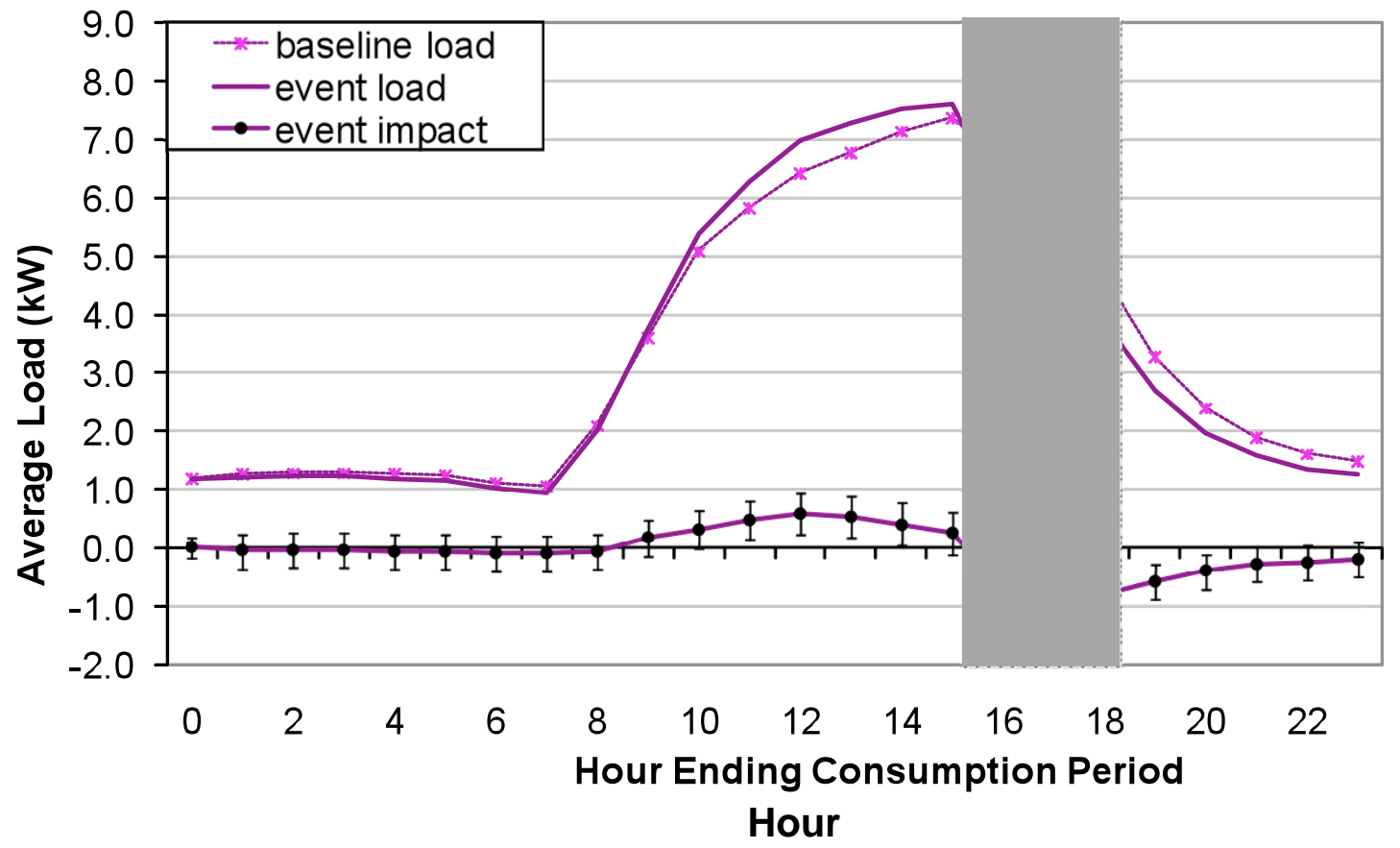

Figure 24. Average loads on event and non-event days, CPP retail $(\mathrm{N}=20)$ 


\subsubsection{Comparison of Load Impacts}

This section reviews the hourly load impacts from the most promising business-program combinations: offices and retail stores on the 4-degree ACC and CPP programs. Load impact graphs show $95 \%$ confidence intervals for each hour.

\section{CPP vs. 4-degree ACC}

Figure 25 shows similar and significant load drops in all three event hours for both programs. For the CPP participants, some increase can be seen in the hours before the event, but in no hours are these increases statistically significant from zero. Hours after the event also show no significant deviation from zero, presumably because all offices in our sample closed before the end of the peak period (see Figure 6).

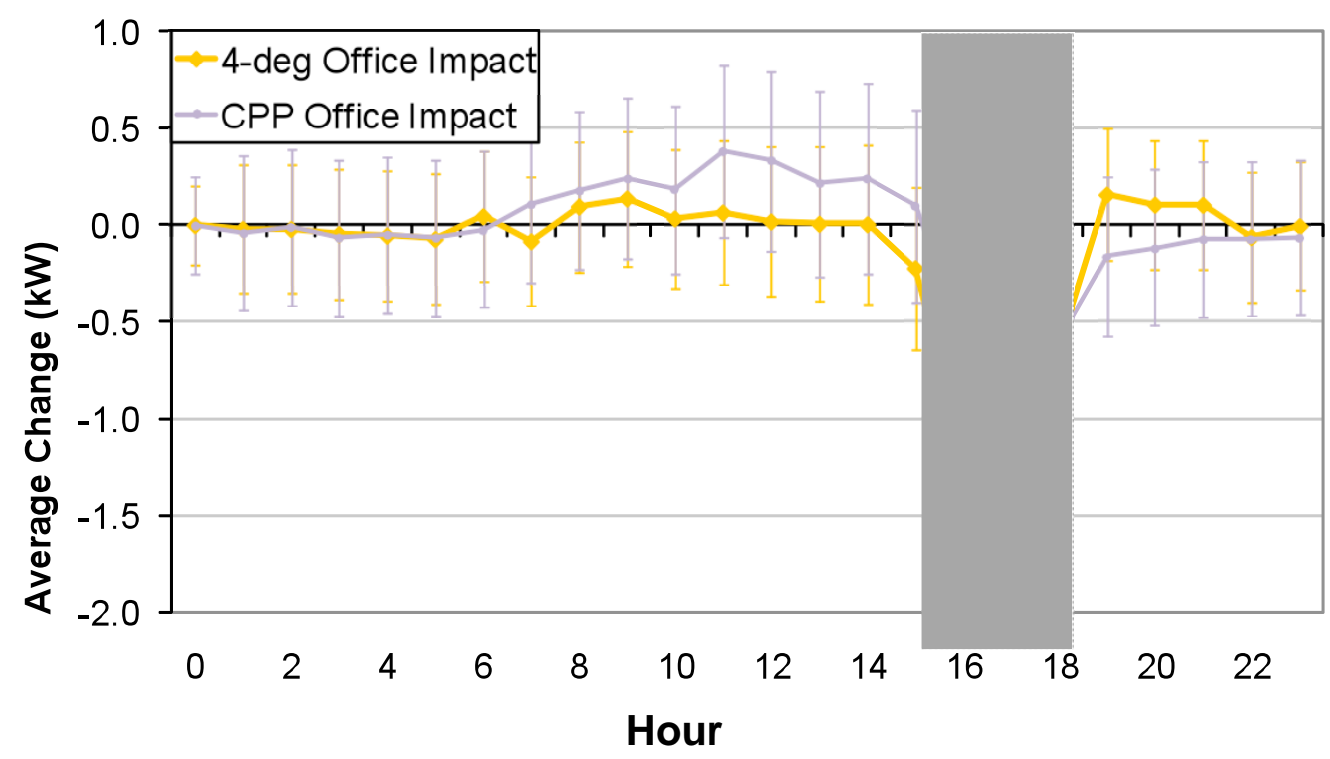

Figure 25. Average kW change on event days, offices 
Figure 26 shows the average load change in the four hours directly preceding the event (precool), in the three hours of the event (event), and in the four hours directly following the event (rebound).

\section{4-deg Offi ce $\quad$ ECPP Offi ce}

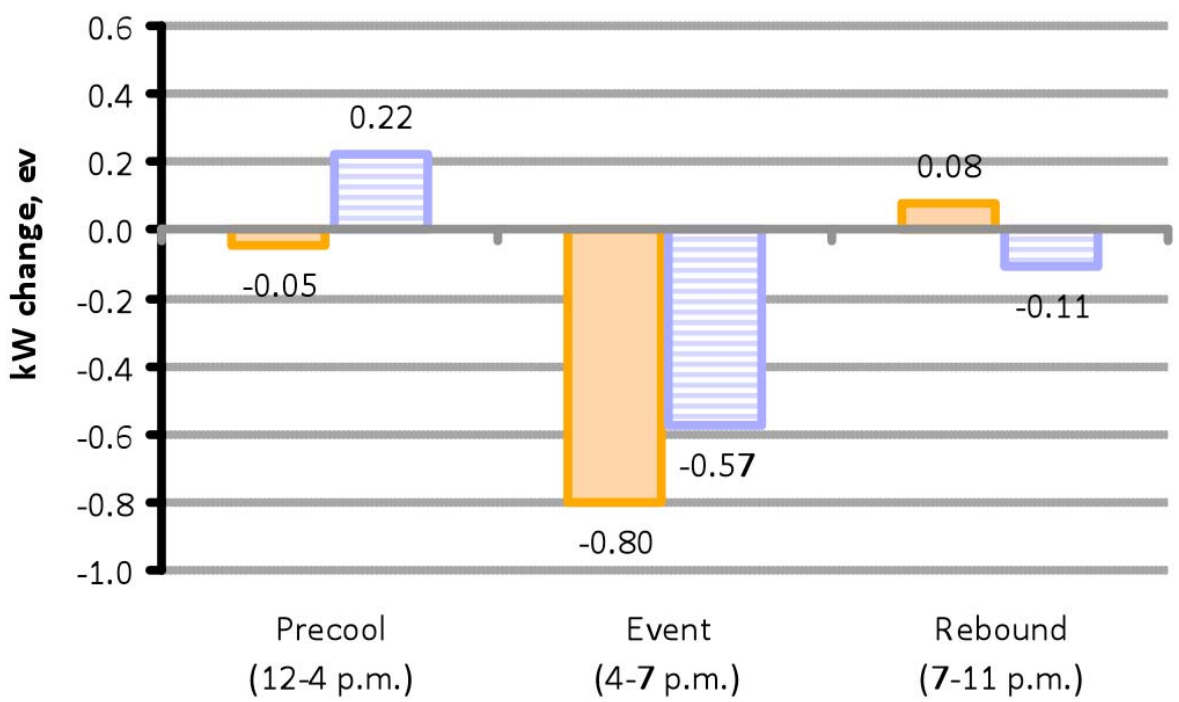

Figure 26. Average precool, event and rebound impacts on event days, offices

Figure 27 and Figure 28 show the load impacts for events at retail stores. Again, there is a significant load drop in each of the three event hours, with the peak load drop reaching nearly 1 $\mathrm{kW}$ for both programs. Here, the precooling effect for the CPP program is significant in all four of the five hours preceding the event. A similar precooling shape is apparent for the 4-degree ACC program, but the impacts are not statistically significant. Neither program elicits a rebound after the event, presumably because most retail shops - about $90 \%$ - close before end of the event (see Figure 6).

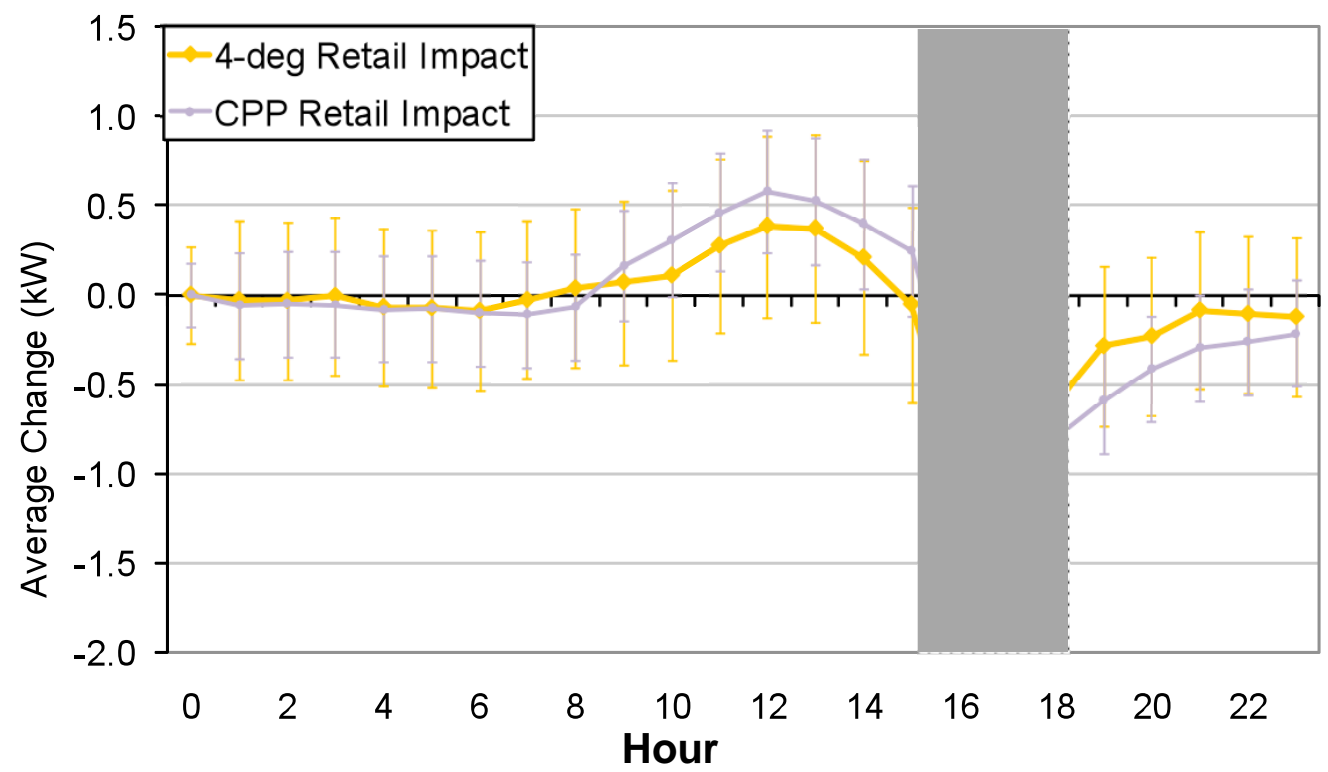

Figure 27. Average kW change on event days, retail stores 


\section{4-deg Retail $\quad$ C CPP Retail}

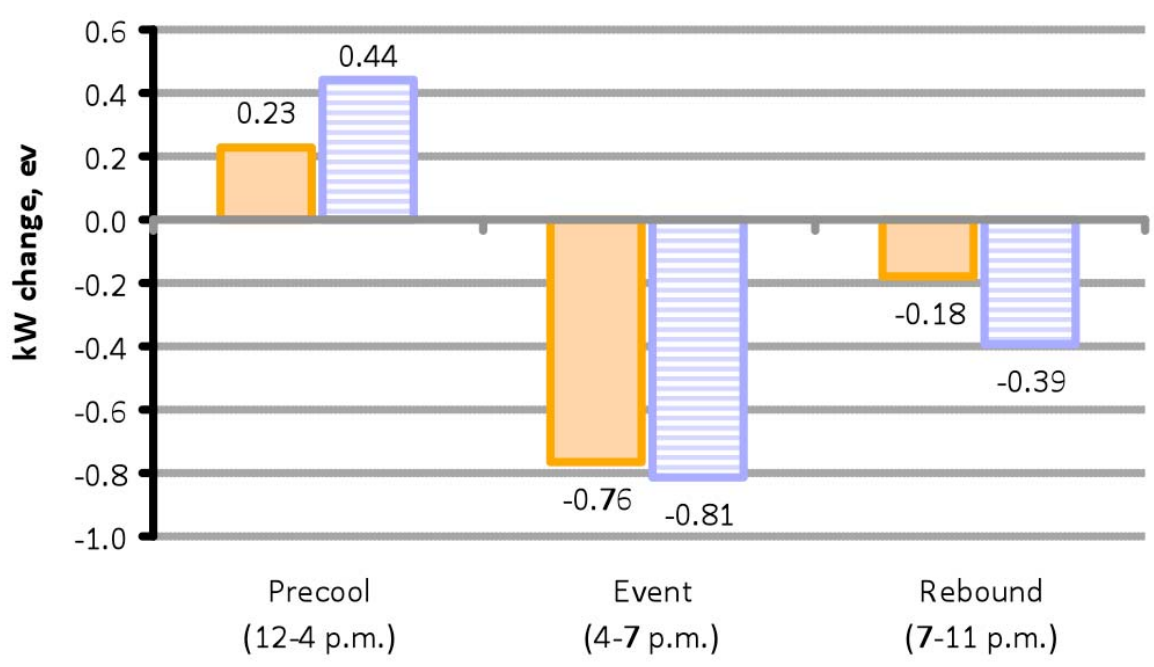

Figure 28. Average precool, event and rebound impacts on event days, retail

\section{Offices vs. Retail}

Figure 29 through Figure 32 show the same load impact data shown in

Figure 25 through Figure 28, but with the opposite comparison combinations. Here, we compare the load impacts of offices to the load impacts of retail, when both are on the same program.Figure 29 and Figure 30 show the nearly identical load impacts of offices and retail stores on the 4-degree ACC program.

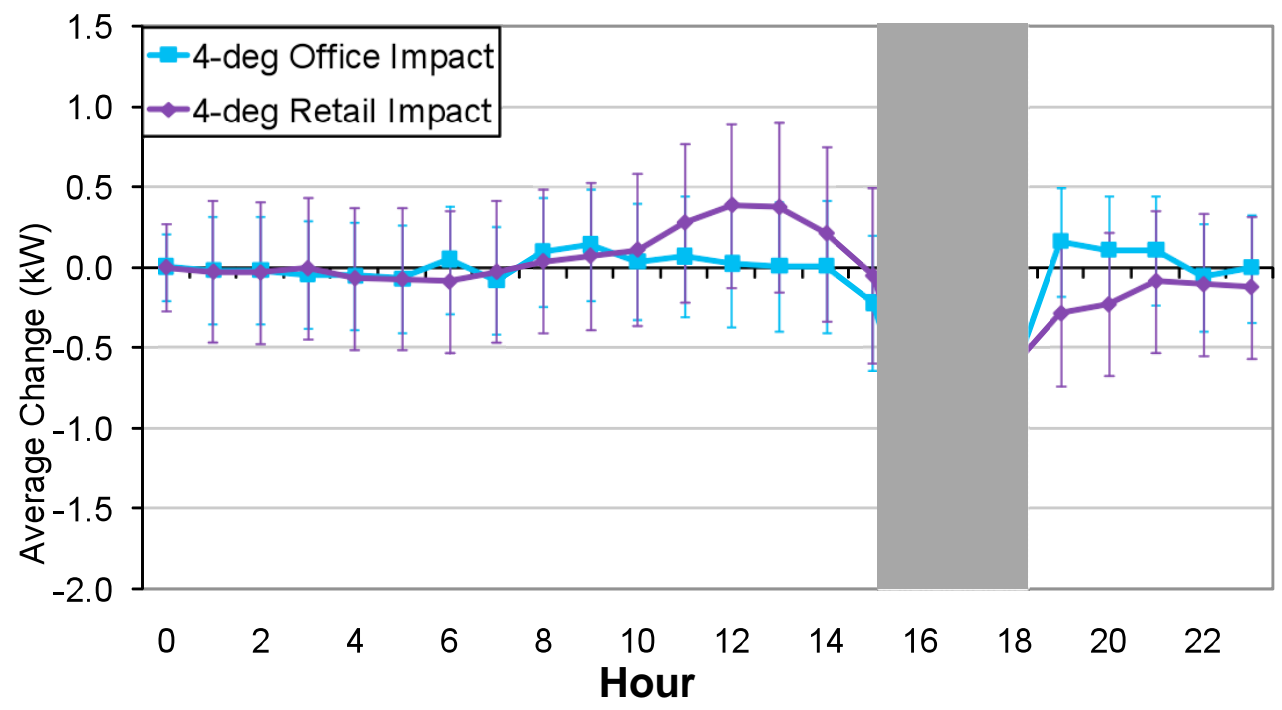

Figure 29. Average kW change on event days, 4-degree ACC 


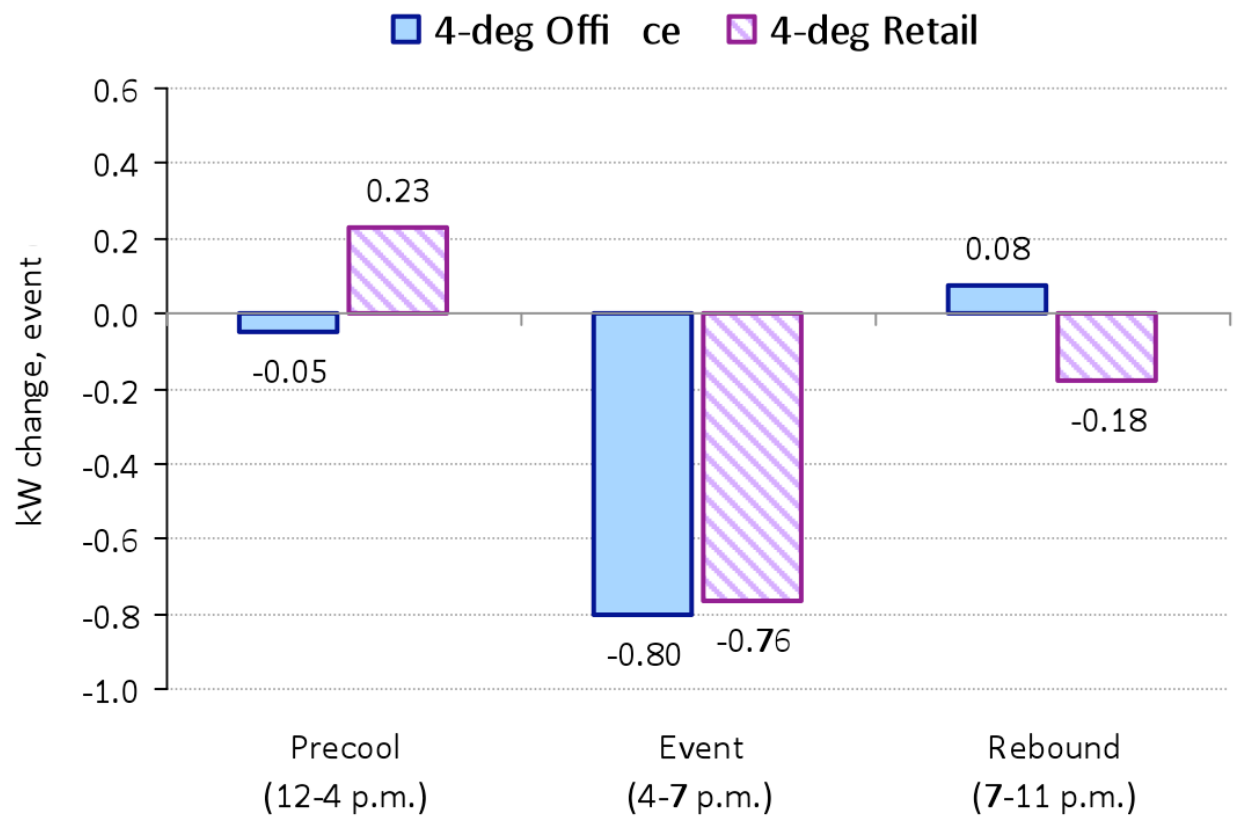

Figure 30. Average precool, event and rebound impacts on event days, $4^{\circ} \mathrm{ACC}$

Figure 31 and Figure 32 show that the load impacts for offices and retail stores have similar shapes. Retail has higher precooling and event impacts, but the difference is not statistically significant.

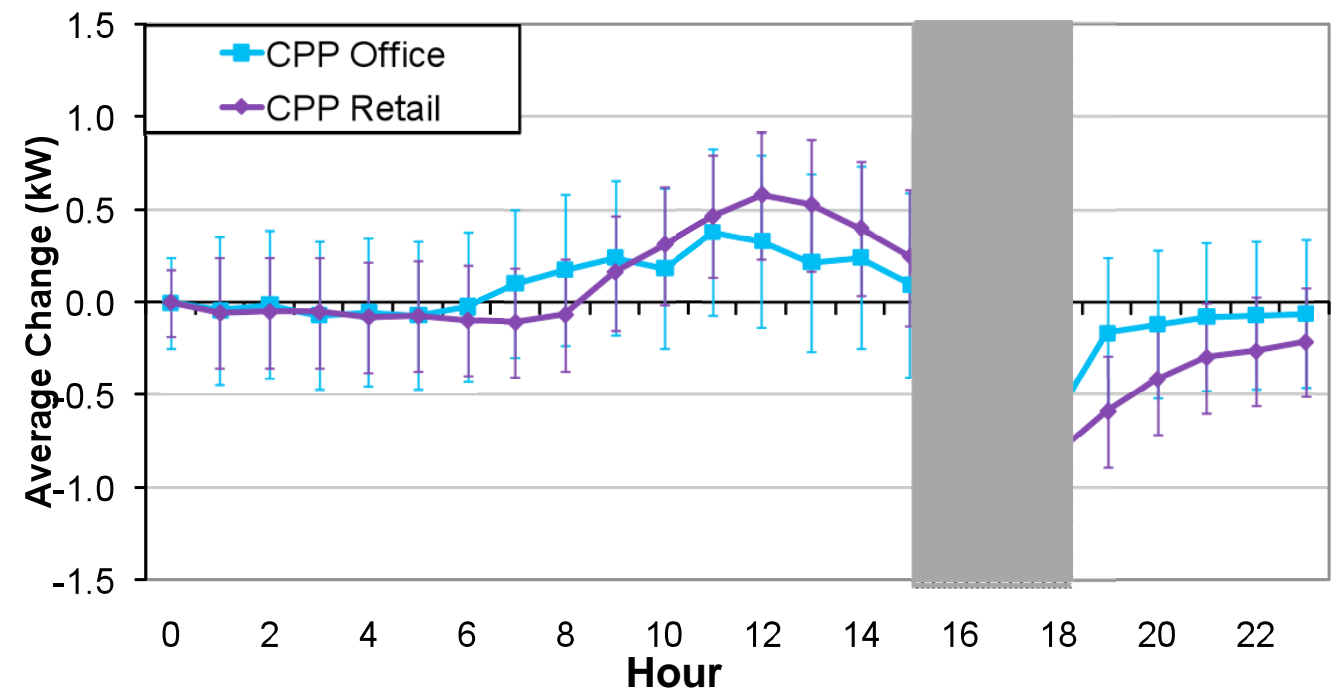

Figure 31. Average kW change on event days, CPP 


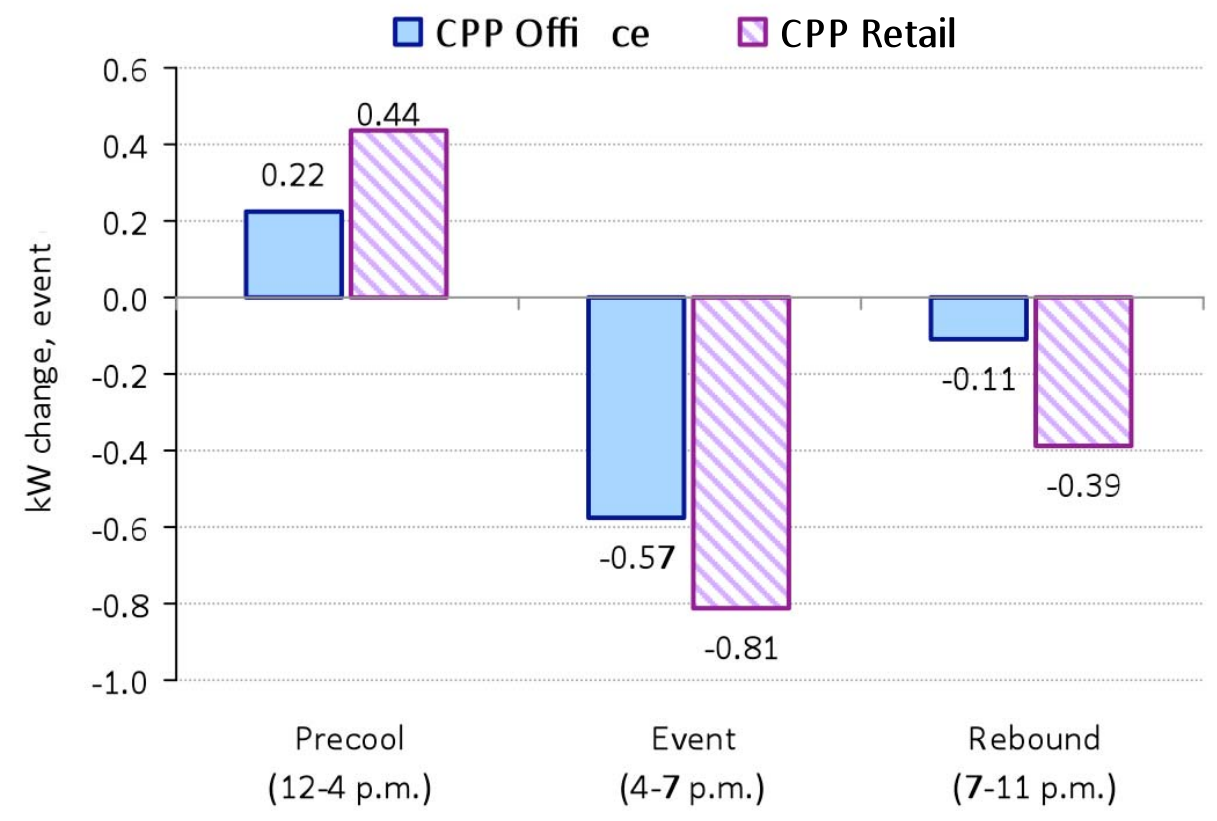

Figure 32. Average precool, event and rebound impacts on event days, CPP 


\subsection{Energy Impacts: Summer 2007 vs. Summer 2008}

A regression of monthly usage ( $\mathrm{kWh}$ ) on average monthly temperature (Equation 3 ) was used to estimate the weather-corrected energy savings for the $4^{\circ}$ ACC participants, the CPP participants, and a control group of non-participants (Table 13). The small number of $2^{\circ}$ ACC participants prevented statistically useful results, so are not included here.

$$
\begin{array}{r}
k W h_{i j}=\beta_{0}+\beta_{1} C D D_{i}+\beta_{2} \text { Year }_{i}+\beta_{3-4} \text { Program }_{j}+\beta_{5-6} \text { BusinessType }_{j}+ \\
\beta_{7-8} \text { Year }_{i j} \cdot \text { Program }_{j}+\beta_{9-10} \text { Year }_{i} \cdot \text { BusinessType }_{j}+\varepsilon_{i j}
\end{array}
$$

Where:

- $\mathrm{kWh}_{\mathrm{ij}}$ is the consumption for month $\mathrm{i}$ for customer $\mathrm{j}$

- $\mathrm{CDD}_{\mathrm{i}}$ is the total cooling degree days (base 75) for month $\mathrm{i}$

- Year $_{\mathrm{i}}$ is a dummy variable equal to one if month i falls in 2008

- $\quad$ Program $_{\mathrm{j}}$ is a set of two dummy variables for program (None, 4-deg offset, CPP)

- BusinessType is a set of two dummy variables for business type (Restaurant, Retail, Office)

\begin{tabular}{|c|c|c|c|c|c|c|}
\hline \multirow[t]{2}{*}{$\begin{array}{l}\text { Business } \\
\text { Type }\end{array}$} & \multirow[t]{2}{*}{ Program } & \multicolumn{2}{|c|}{$\begin{array}{l}\text { Average Monthly } \\
\text { kWh }\end{array}$} & \multicolumn{2}{|c|}{$\begin{array}{l}\text { 2007-2008 } \\
\text { Difference }\end{array}$} & \multirow{2}{*}{$\begin{array}{c}\text { 2007-2008 Difference } \\
\text { Corrected for Non- } \\
\text { Participant Change } \\
(\%)\end{array}$} \\
\hline & & $\begin{array}{l}\text { Summer } \\
2007\end{array}$ & $\begin{array}{l}\text { Summer } \\
2008\end{array}$ & $(k W h)$ & $(\%)$ & \\
\hline \multirow{3}{*}{ Office } & None (control) & 1025 & 976 & $49^{*}$ & $-5 \%$ & \\
\hline & $4^{\circ} \mathrm{ACC}$ & 934 & 631 & $303^{*}$ & $-32 \%$ & $-27 \%$ \\
\hline & CPP & 1061 & 668 & $393^{*}$ & $-37 \%$ & $-32 \%$ \\
\hline \multirow{3}{*}{ Restaurant } & None (control) & 3340 & 3252 & $88^{*}$ & $-3 \%$ & \\
\hline & $4^{\circ} \mathrm{ACC}$ & 3249 & 2907 & 342 & $-11 \%$ & $-8 \%$ \\
\hline & CPP & 3377 & 2944 & $432^{*}$ & $-13 \%$ & $-10 \%$ \\
\hline \multirow{3}{*}{ Retail } & None (control) & 1754 & 1716 & $38^{*}$ & $-2 \%$ & \\
\hline & $4^{\circ} \mathrm{ACC}$ & 1663 & 1370 & 292 & $-18 \%$ & $-15 \%$ \\
\hline & CPP & 1790 & 1408 & $383^{*}$ & $-21 \%$ & $-19 \%$ \\
\hline Average & $\begin{array}{l}4^{\circ} \mathrm{ACC} \text { and } \\
\mathrm{CPP} \text { participants }\end{array}$ & 1543 & 1197 & $346^{*}$ & $-23 \%$ & $-20 \%$ \\
\hline
\end{tabular}

Table 13. Summer Solutions Participant Energy Savings

Overall, program participants used significantly less energy in 2008 than they did in 2007. Correcting for non-participant savings, the Summer Solutions program participants saved over 
$300 \mathrm{kWh}$ per month on average, representing a 20 percent overall energy savings for the pilot. These results indicate that the pilot was successful in achieving (and surpassing) our original energy savings goal of just 5 percent.

\subsection{CPP Bill Impacts}

Table 14 shows the mean monthly GSN and CPP bills, CPP savings relative to the standard GSN tariff, estimated bill savings attributable to energy efficiency, and total bill savings. On average, each business type saved about 5\% of their bill on the CPP tariff relative to the GSN rate. The inclusion of energy efficiency related savings boosts total bill savings to over $\$ 50$ for offices and retail, and to $\$ 75$ for restaurants, representing an estimated savings of over $30 \%$ for offices and retail, and a respectable $13 \%$ for restaurants.

Table 14. Summary of bill effects for CPP participants

\begin{tabular}{|c|c|c|c|c|c|c|c|c|c|c|c|}
\hline \multirow[t]{2}{*}{ Business Type } & \multirow[t]{2}{*}{$\mathbf{N}$} & \multicolumn{2}{|c|}{$\begin{array}{c}\text { Average } \\
\text { Summer } 2008 \\
\text { Monthly Bill }\end{array}$} & \multicolumn{3}{|c|}{$\begin{array}{l}\text { CPP Bill } \\
\text { Impacts }\end{array}$} & \multicolumn{2}{|c|}{$\begin{array}{l}2007-2008 \\
\text { Efficiency } \\
\text { Savings }\end{array}$} & \multicolumn{3}{|c|}{$\begin{array}{l}\text { Total Bill } \\
\text { Savings }\end{array}$} \\
\hline & & $G S N^{*}$ & $C P P$ & $\$$ & & $\%$ & $\$$ & & $\$$ & $\$$ & $\%$ \\
\hline Office & 23 & $\$ 139$ & $\$ 132$ & $\$$ & 7 & $5.0 \%$ & $\$$ & 44 & $\$$ & 51 & $37 \%$ \\
\hline Retail & 20 & $\$ 164$ & $\$ 156$ & $\$$ & 8 & $4.7 \%$ & $\$$ & 43 & $\$$ & 51 & $31 \%$ \\
\hline Restaurant & 8 & $\$ 564$ & $\$ 537$ & $\$$ & 26 & $4.7 \%$ & $\$$ & 49 & $\$$ & 75 & $13 \%$ \\
\hline All & 51 & $\$ 215$ & $\$ 205$ & $\$$ & 10 & $4.8 \%$ & $\$$ & 45 & $\$$ & 55 & $26 \%$ \\
\hline Office + Retail & 43 & $\$ 151$ & $\$ 139$ & $\$$ & 7 & $4.9 \%$ & $\$$ & 44 & $\$$ & 51 & $34 \%$ \\
\hline
\end{tabular}

Assuming similar GSN bills, ACC offices, retail stores and restaurants saved a total of 32\%, $26 \%$, and $9 \%$, respectively, for an overall average of $20 \%$ bill savings for all ACC participants, and $29 \%$ savings for just the office and retail ACC participants.

\subsubsection{CPP Impacts (not including 2007-2008 efficiency savings)}

Figure 33 plots the difference between GSN and CPP bills - in both dollar and percentage terms, showing that all but four of the CPP participants saved money on the experimental rate. While the greatest savings was $\$ 178$, the greatest bill increase was only $\$ 20$ (or about $10 \%$ of the standard bill). 


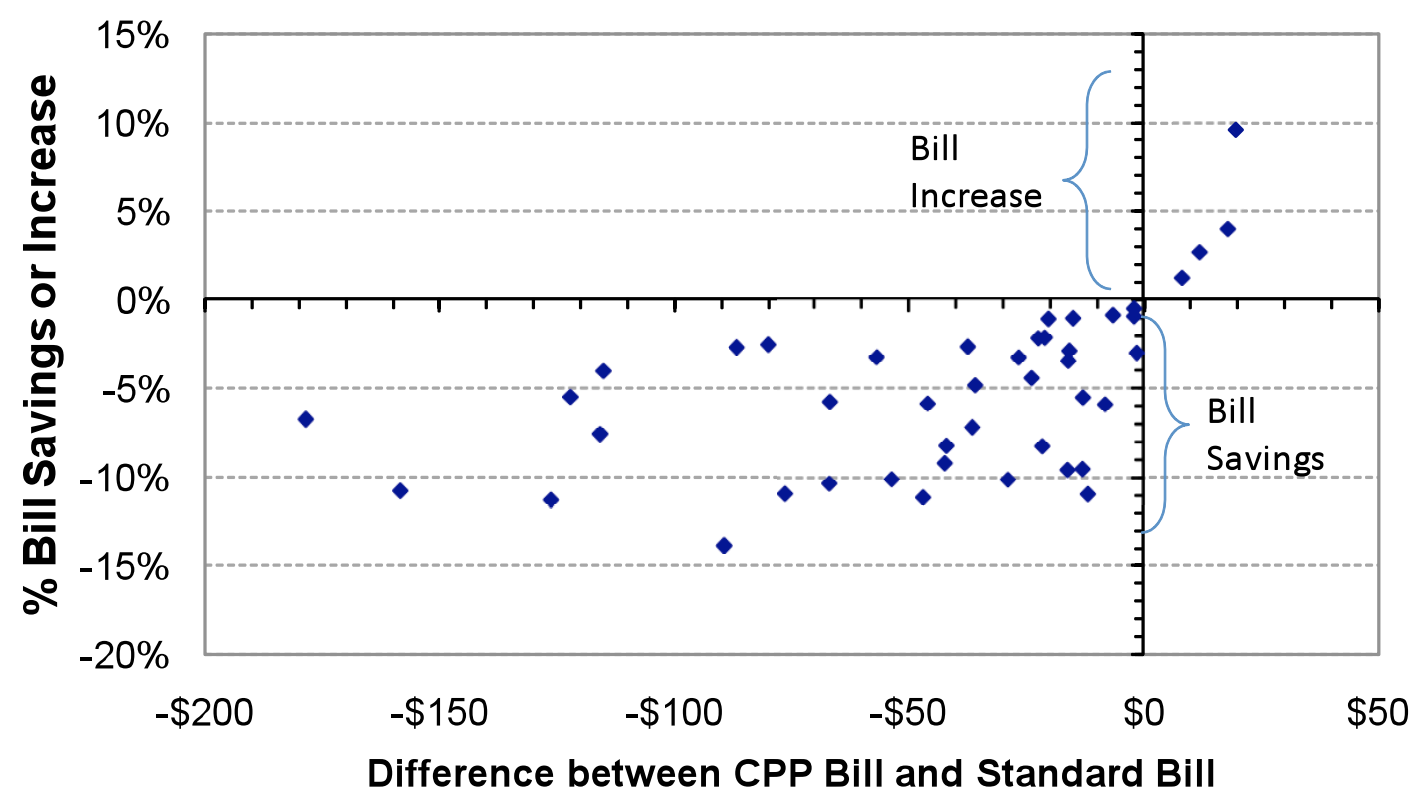

Figure 33. Dollars vs. percent bill change, CPP participants

The participant with the largest dollar savings over the course of the summer was a restaurantbar, with savings totaling over \$178. A likely factor in the large savings was the schedule - a steady 10 a.m. to 2 a.m. seven days a week. This helped to reduce the ratio of peak to non-peak hours, increasing savings. This business also precooled their building every day by opening windows. Unsurprisingly, this customer said they would definitely participate in the program again without an incentive payment.

The largest bill increase, in both dollar and percentage terms, occurred in a suite of offices, with just one thermostat located in one of the three offices sharing a single electric account. The total bill increase for the summer was about \$20 (less than 10\%). One possible contributing factor is that each office had its own hours of operation, so the thermostat had be set at the lowest common denominator, wasting energy cooling empty offices when there were only one or two people there. Despite the bill increase, this participant said they would probably participate in the program again without a participation payment, and that their already positive opinion of SMUD was not changed by this pilot.

The participant with the largest percent savings on their bill (nearly 14\%) was an auto retailer. This participant resided in a relatively new (5 years) and small (500 sq. ft.) building with a window air conditioner. Business is generally conducted outside in the car lot, so customer complaints are not a major concern. Like the restaurant-bar described above, this participant also said they would definitely participate in the program again without an incentive payment. Additionally, this participant indicated that their opinion of SMUD had improved as a result of this pilot. 


\subsubsection{Bills vs. Usage}

Figure 34 and Figure 35 compare load change to bill savings for CPP participants. As before, the size of the bubble indicates the number of events for which each participant received and responded to the event notification. The color of the bubbles indicates whether the participant had installed a communicating thermostat.

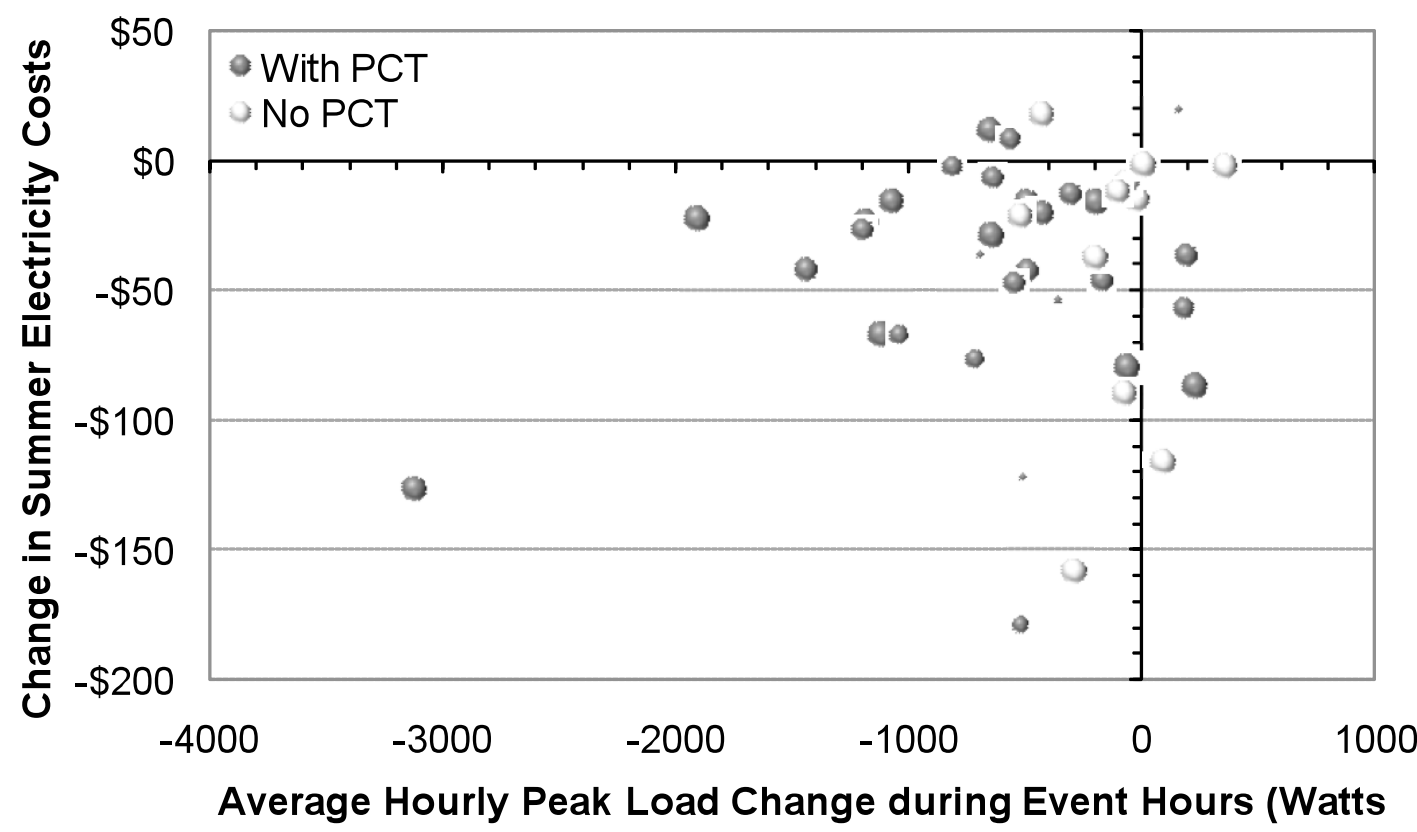

Figure 34. Summer bill savings vs. load change for event period

The white bubbles are all the same size because these customers did not have a thermostat, and therefore received a phone call or email notifying them of each event. The smallest bubbles indicate that no event notifications were received by the thermostat - however, most of these participants were also notified by email, and so could have responded manually. The largest received all twelve event notifications.

Figure 34 shows the change in participant bills compared to the change in their energy usage during the event period (4-7 p.m.). There appears to be a relatively good correlation between event response and bill savings, with all but nine of the CPP participants located in the third (bottom left) quadrant of the plot.

A small group of participants managed to save money despite increasing their usage during event periods, while an even smaller group had increased bills despite dropping some load. However, the vast majority of CPP participants saved money on their bills and dropped load during event periods.

Figure 35 shows the bill savings of CPP participants compared with their change in energy usage on event days. It is interesting to note that all but one of the participants that increased their load on event days managed to reduce their bills overall. 


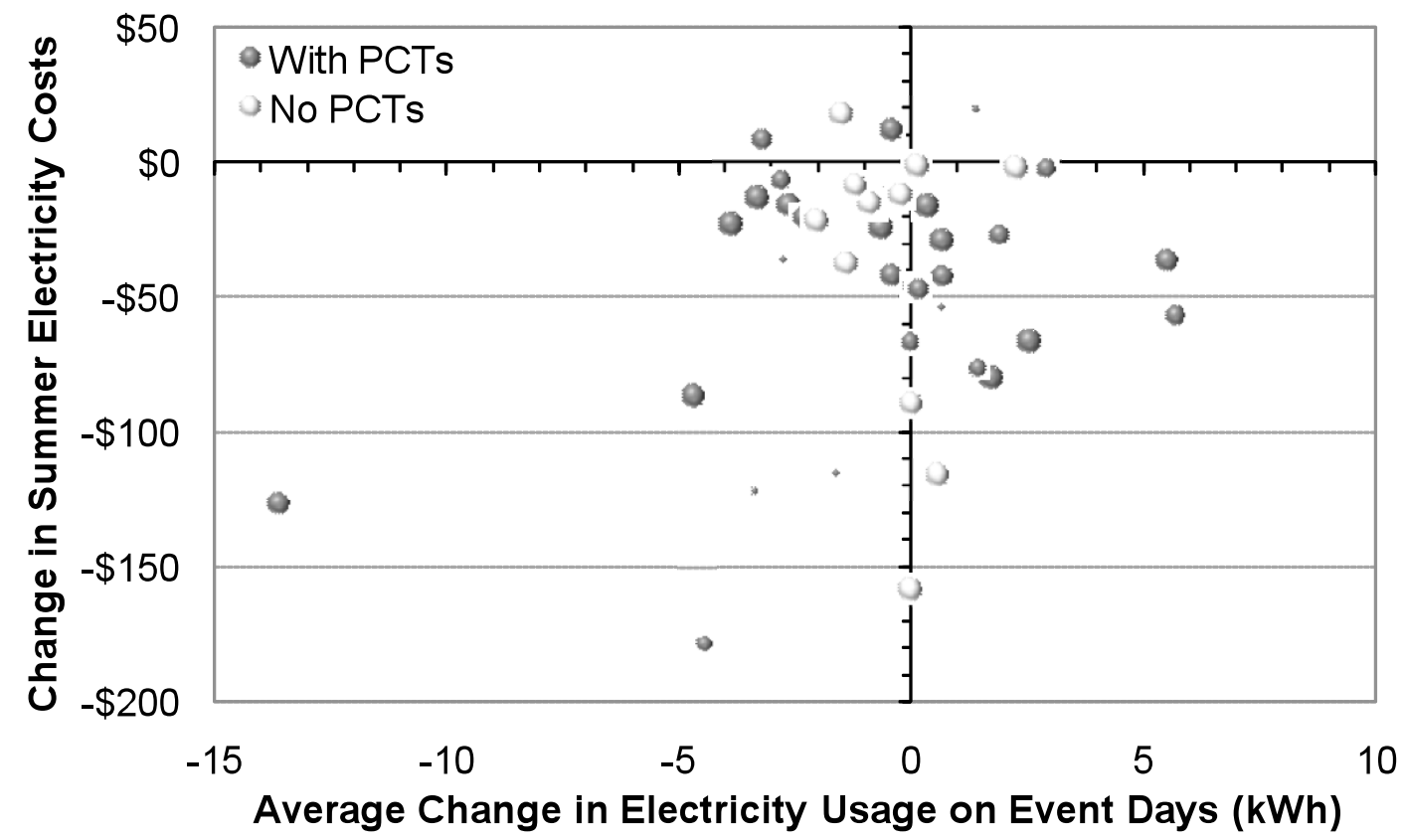

Figure 35. Summer bill savings vs. load change for entire event day

\subsection{Participant Surveys}

The study included participant surveys before, during and after the summer 2008 field study. The Spring Survey focused on building and customer characteristics. Event Surveys collected after each event recorded information on customer actions and comfort perceptions. After the field study ended, participants were given the Fall Survey, which recorded information about their experience on the program. A list of all questions on all three surveys and summaries of the responses are provided in Appendix B.

\subsubsection{Load Shifting and Demand Response Behavior}

Figure 36 combines data from the Spring and Fall surveys. It shows the percentage of participants that performed a variety of energy conservation and shifting measures every day before and during the pilot, plus the percentage of participants that performed the same actions only on event days. 


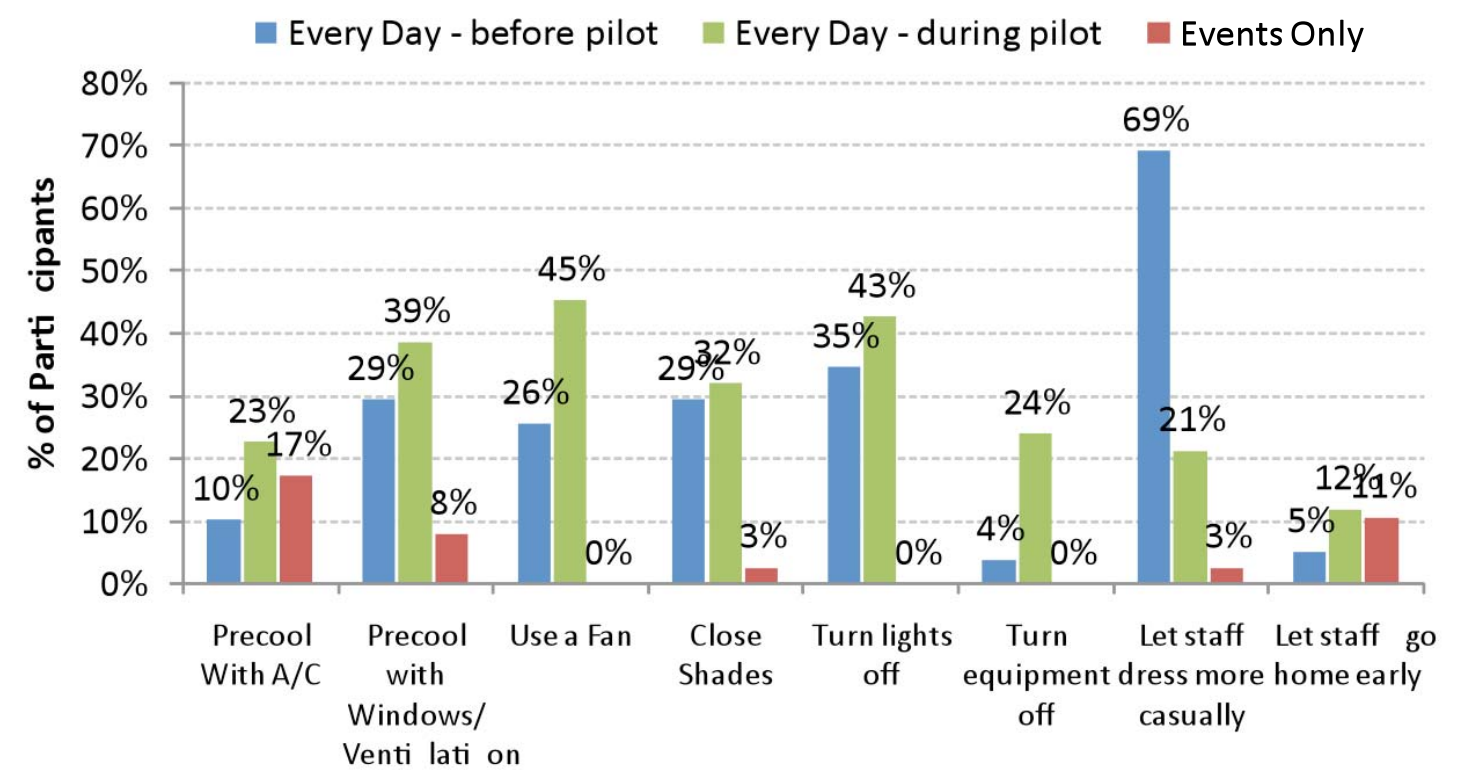

Figure 36. Load shifting and conservation actions before and during the pilot

With the exception of "Let staff dress more casually" question, ${ }^{1}$ the survey responses indicate that all actions were performed by a greater percentage of participants at the end of the pilot than at the beginning of pilot. In addition, all actions taken during "events only" are clearly attributable to the pilot, since events did not exist before the pilot.

Figure 37 and Figure 38 show the actions taken by participants as reported in the Fall Survey. Keep in mind that there are a smaller number of restaurants than offices or retail shops, and similarly, fewer participants on the ACC programs than on the CPP rate.

\footnotetext{
${ }^{1}$ The large decrease in affirmative responses to this question is likely a result of the wording of the question - in particular the use of the word "more" without a clear reference point for comparison.
} 


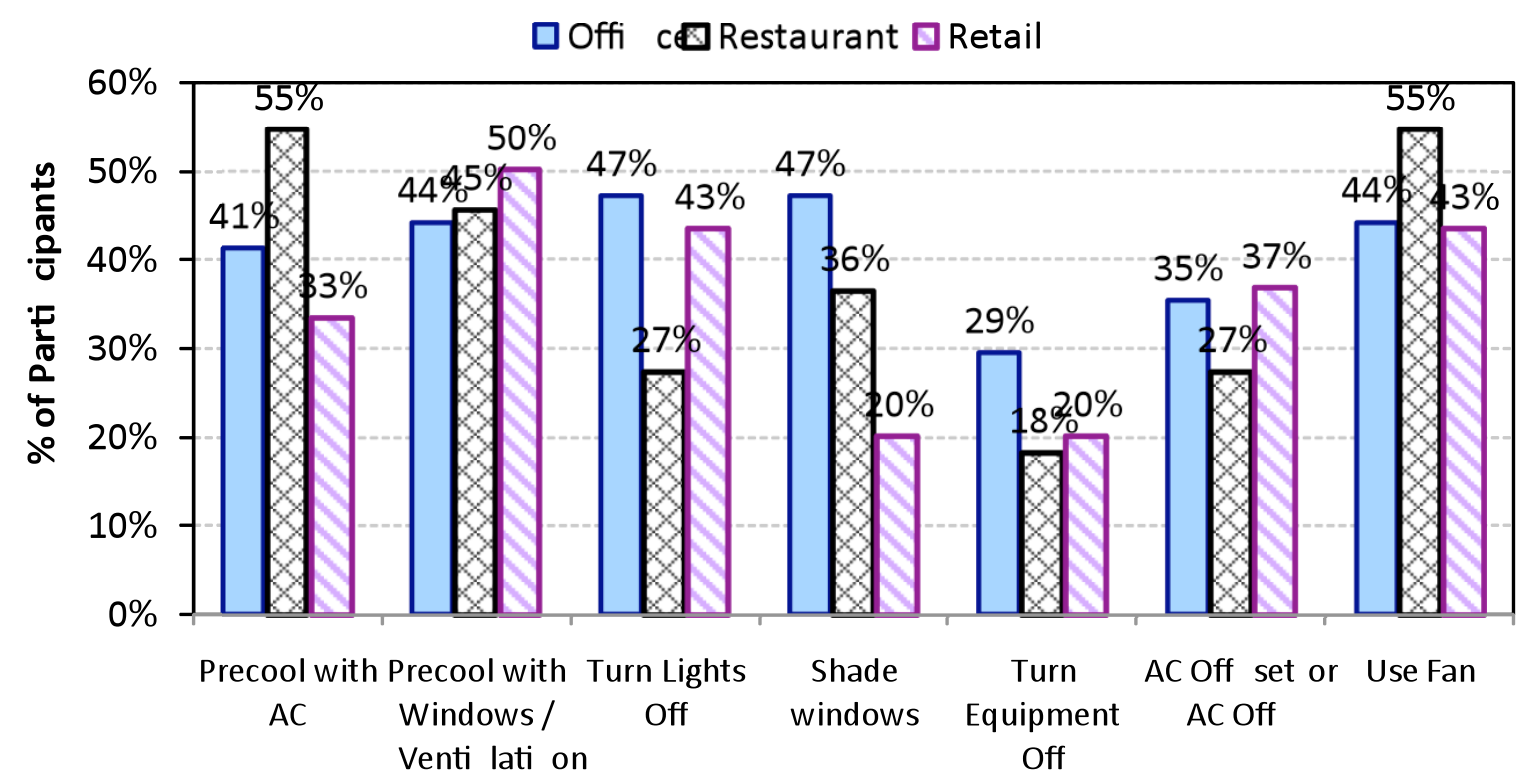

Figure 37. Load shifting and conservation actions during the pilot, by business

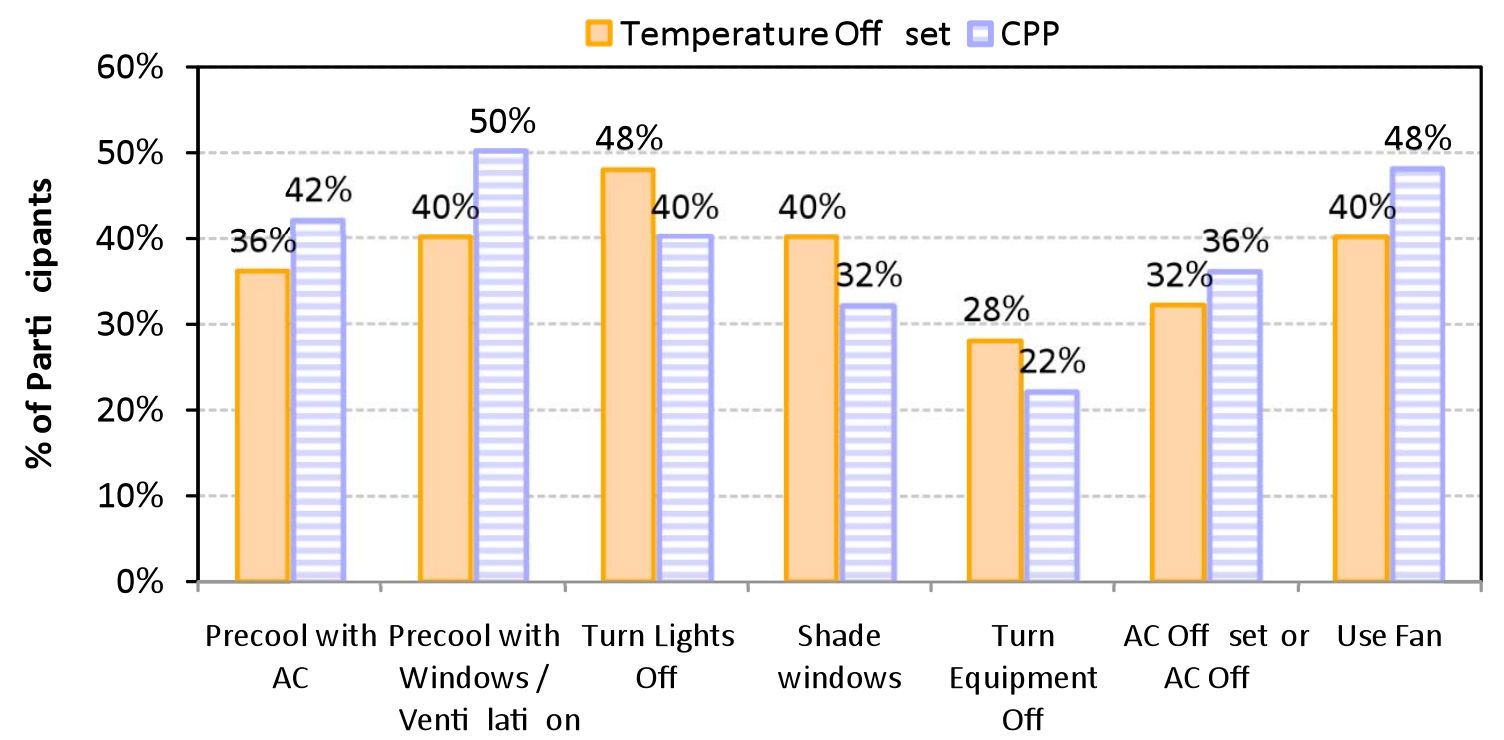

Figure 38. Load shifting and conservation actions during the pilot, by program 


\subsubsection{Summer Surveys: Effects on Business and Comfort}

In general, participants indicated that the demand response events were not very disruptive to their businesses (Figure 39 and Figure 40). Overall, about $90 \%$ of participants said that the events did not affect their business at all, while only $10 \%$ thought that the events affected businesses negatively.

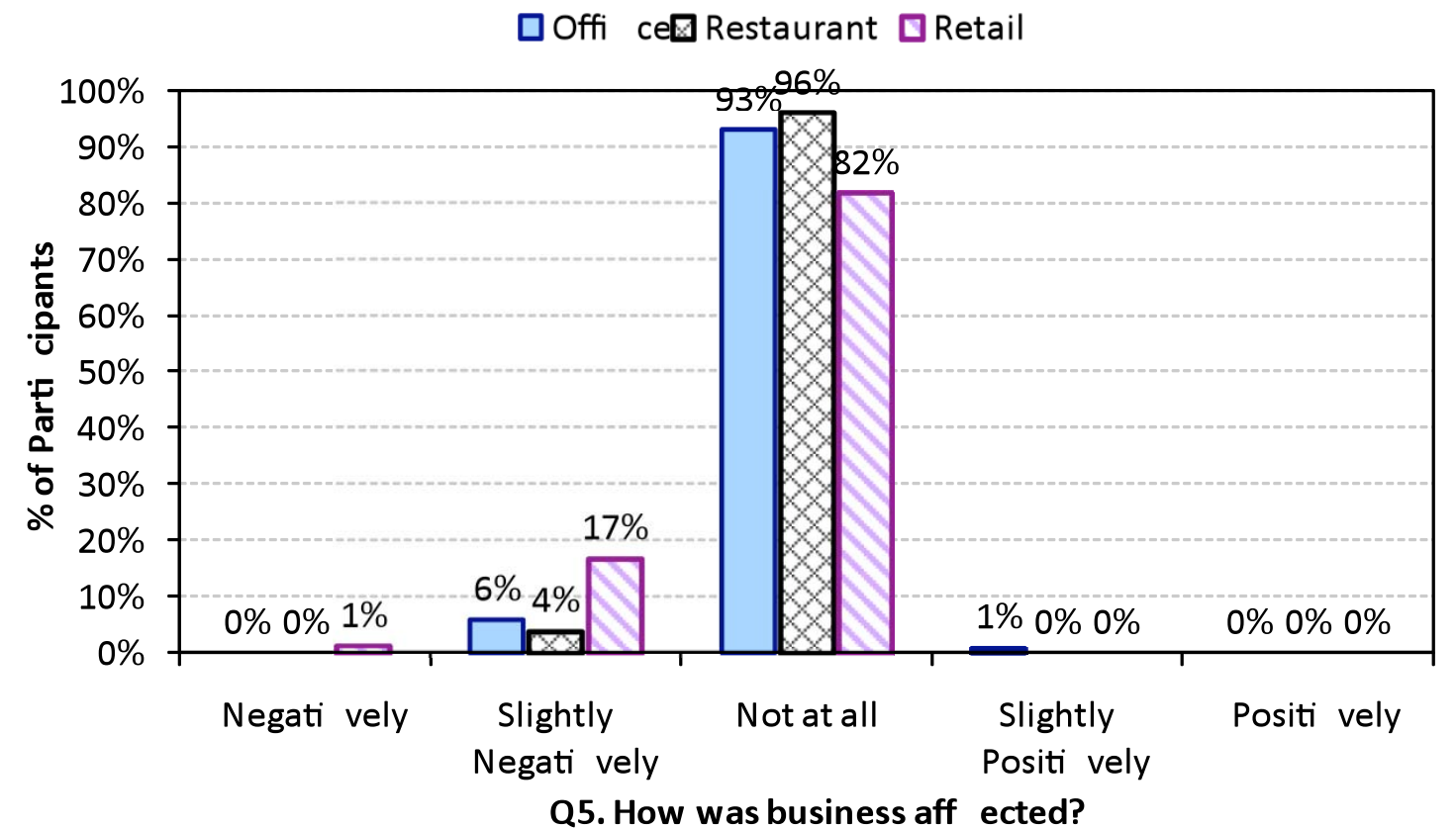

Figure 39. Effects on business, by business type

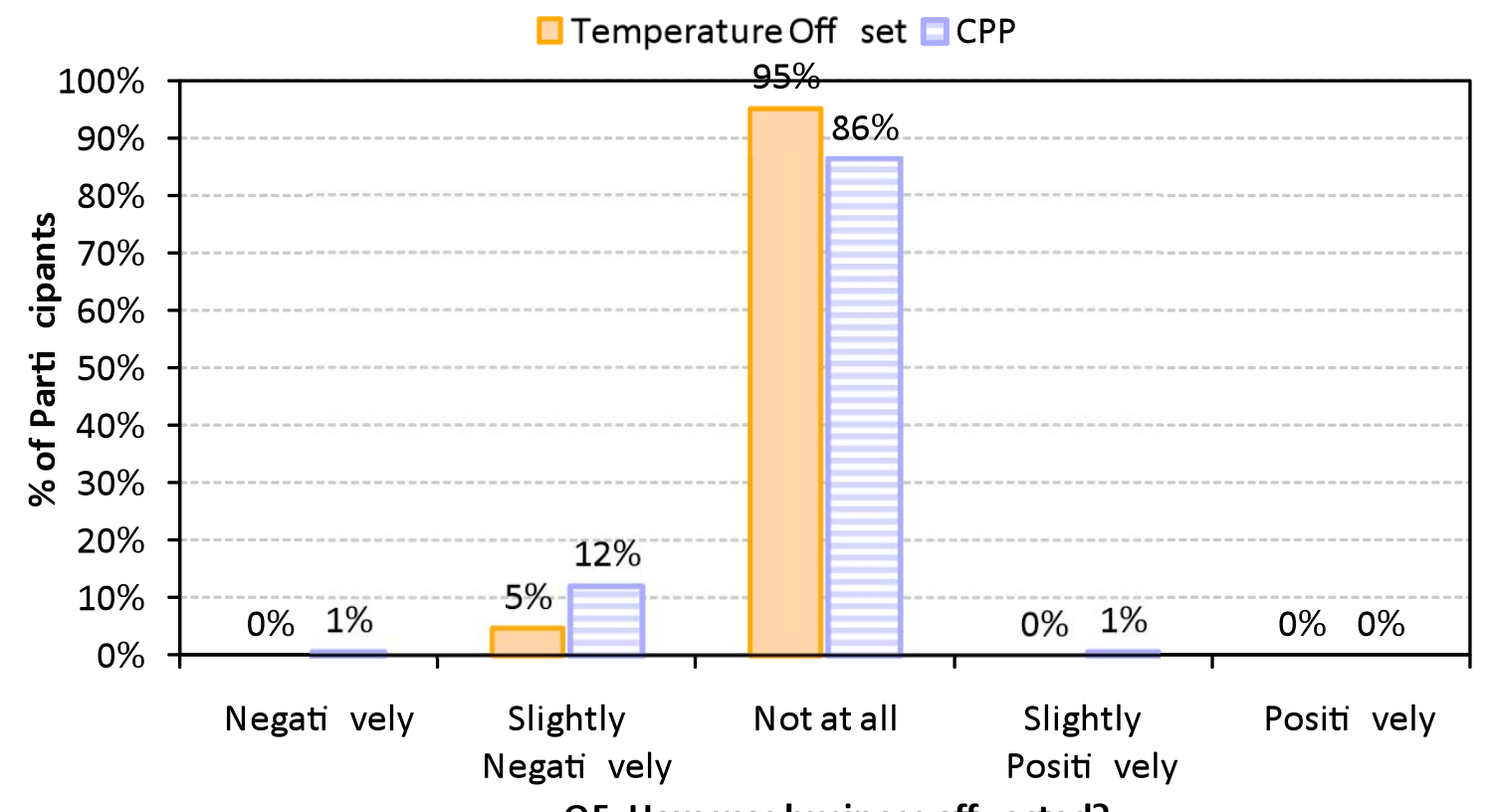

Q5. How was business aff ected?

Figure 40. Effects on business, by program choice 
Figure 41 and Figure 42 show that on average about $10 \%$ of the participants felt that the events made them uncomfortable. This is a positive indicator that demand response for the most part may not be disruptive to the small commercial sector.

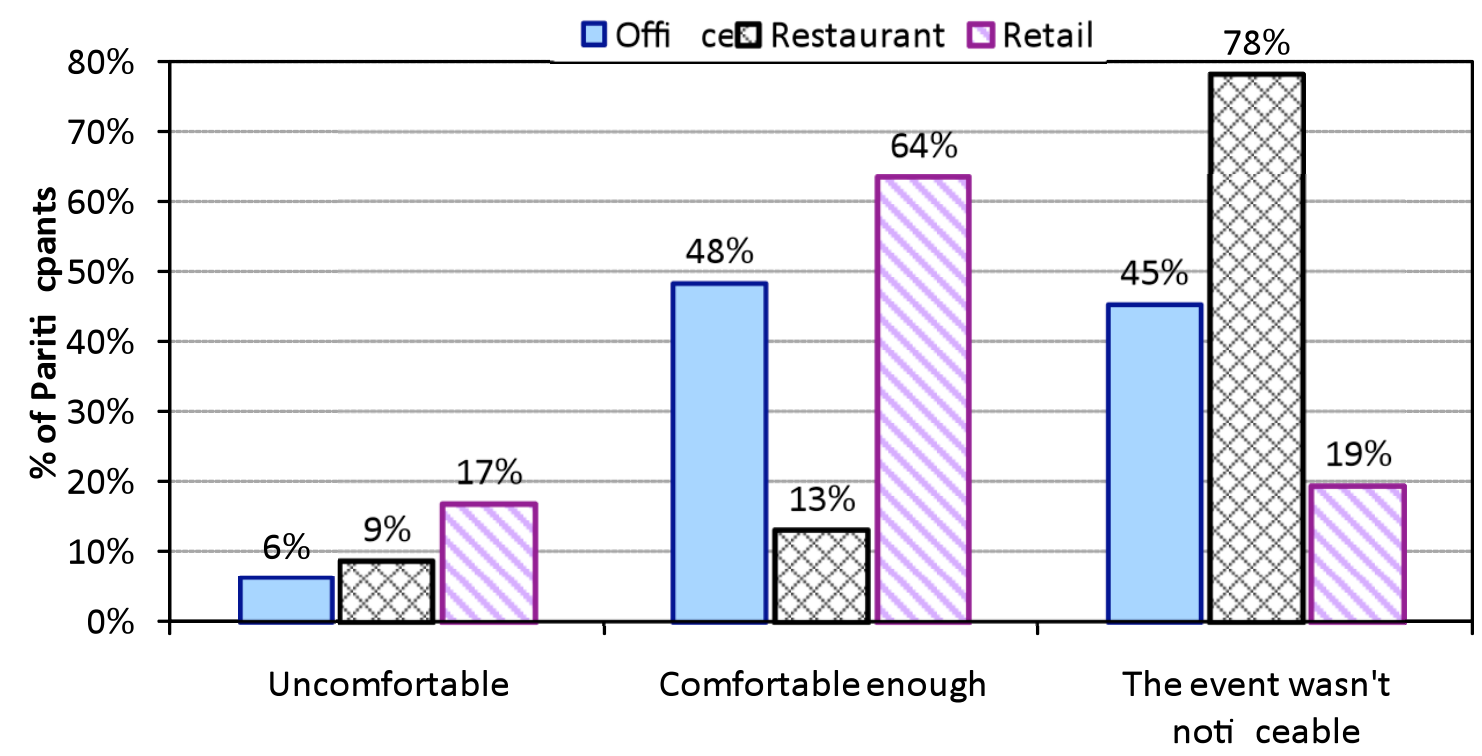

Q3. What was the comfortlevel during the event?

Figure 41. Effects on comfort, by business type

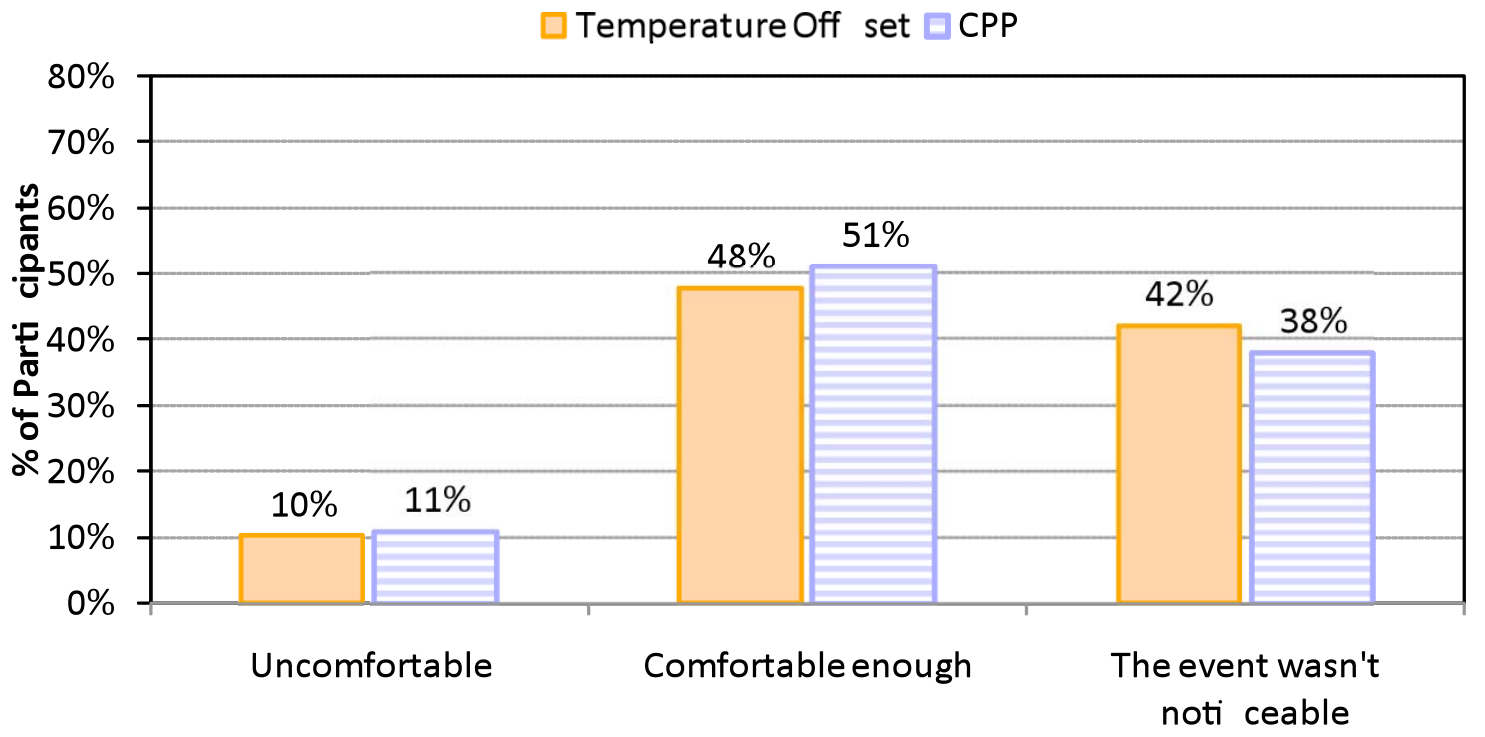

Q3. What was the comfortlevel during the event?

Figure 42. Effects on comfort, by program choice 
Figure 43 and Figure 44 show that there were comments from customers or occupants in about $10 \%$ of the participant events, with slightly more negative than positive comments.

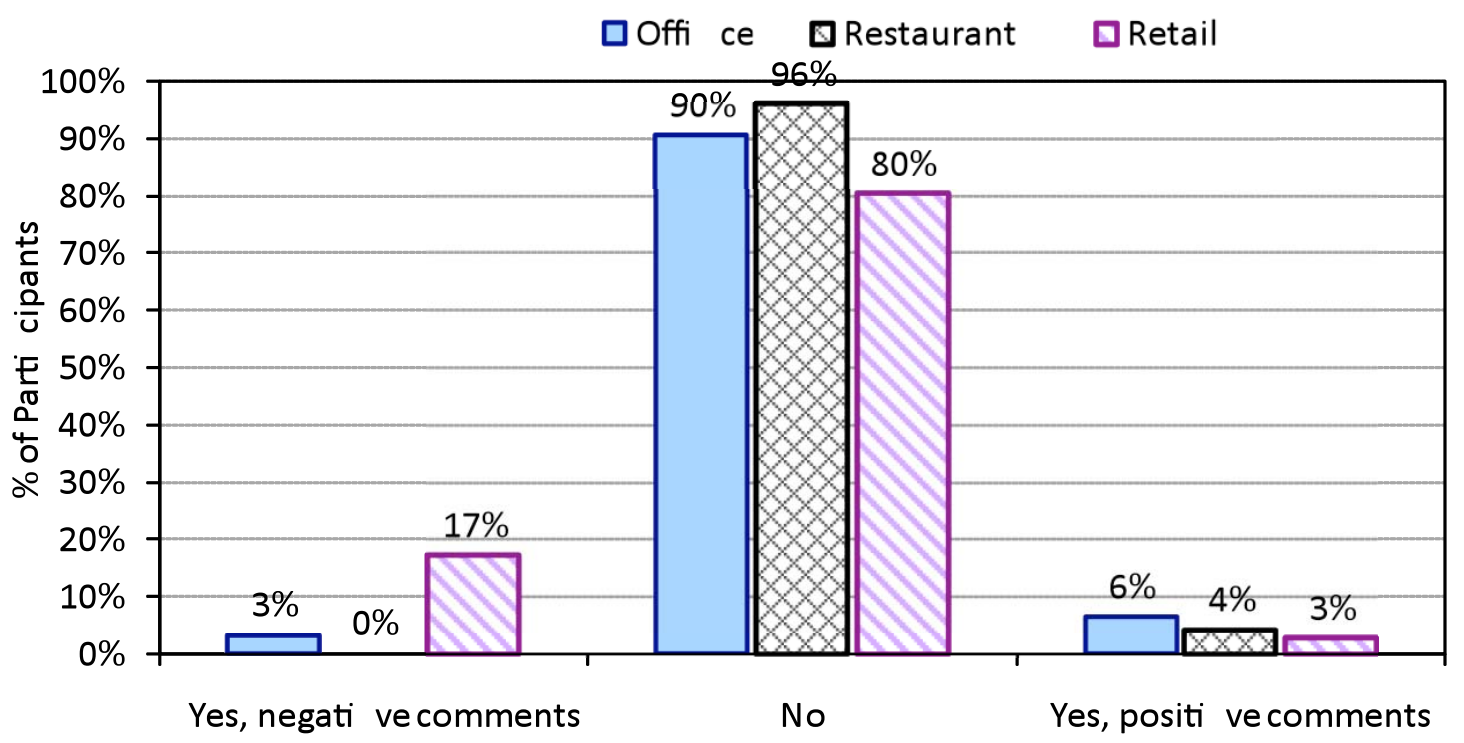

Q4. Were there customer or occupant comments about the event?

Figure 43. Occupant comments, by business type

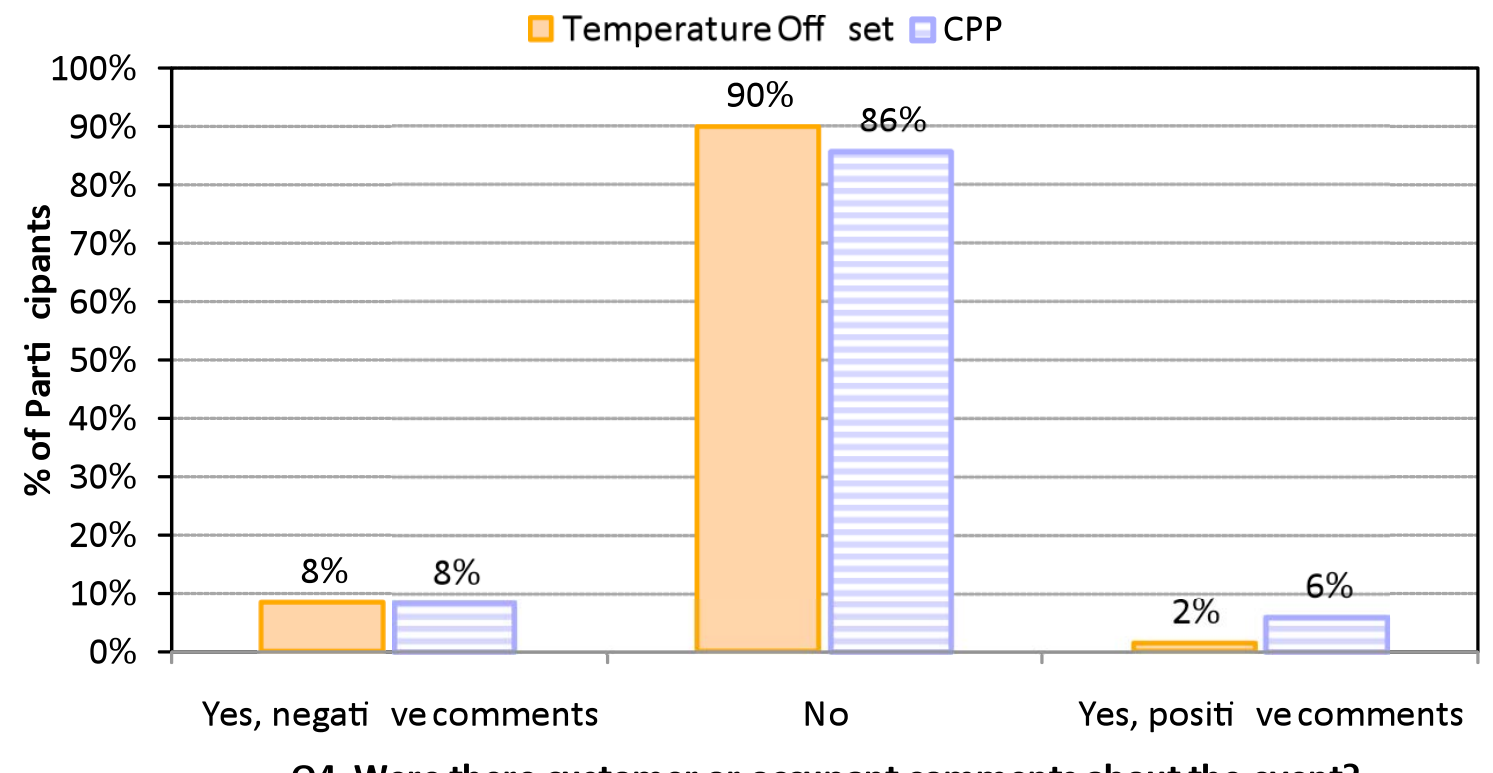

Q4. Were there customer or occupant comments about the event?

Figure 44. Occupant comments, by program choice 


\subsubsection{Fall Survey: Participant Satisfaction}

The Fall Survey was designed to be administered at the end of the summer pilot. Of the 76 participants who remained on the program at the end of the summer, 75 completed the Fall Survey. For full documentation of the survey questions and results, please refer to Appendix B.

\section{Programs}

This section details the results of Fall Survey questions that were related to the ACC and CPP program options.

Figure 45 and Figure 46 depict participants' reasons for choosing their program option. As expected, the majority of participants in all business types signed up for the program they thought would give them the most savings on their electricity bill. The second most common answer was that participants chose the program SMUD recommended.

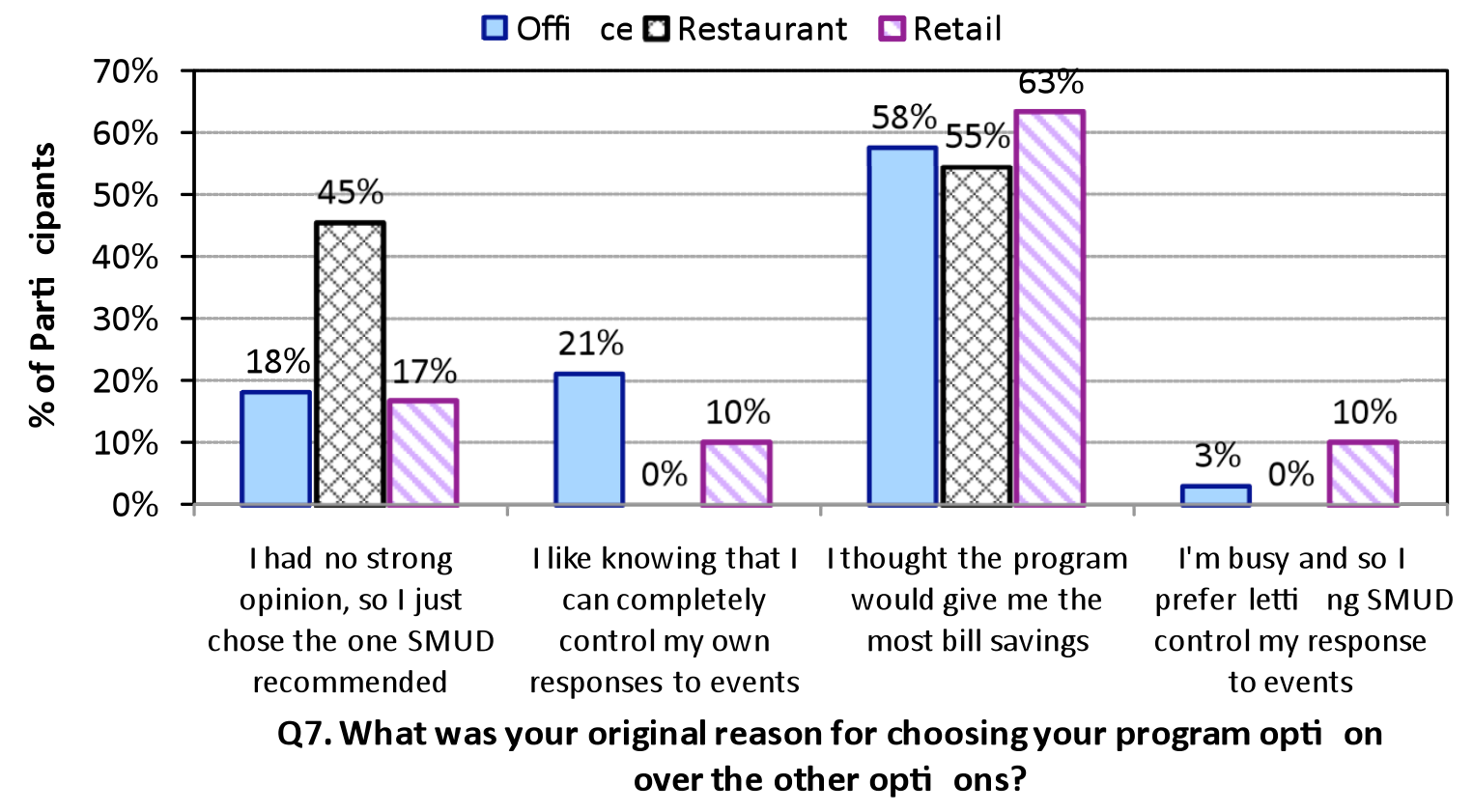

Figure 45. Reason for program choice, by business type 


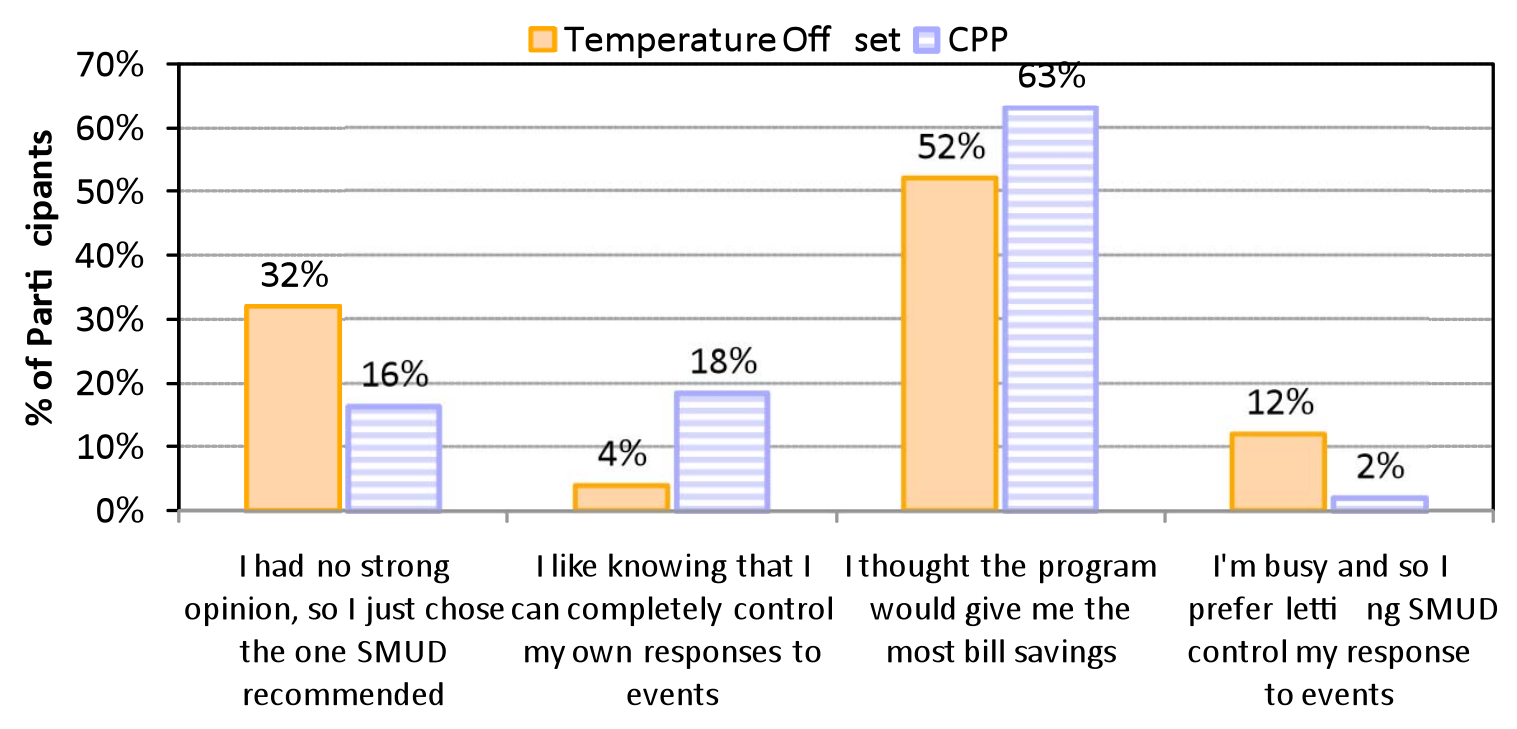

Q7. What was your original reason for choosing your program opti on over the other opti ons?

Figure 46. Reason for program choice, by program choice

Seven people added comments on the Fall Survey detailing the reason why they chose to participate in this pilot in their own words. Two cited the environment as their motivation ("Want to help our environment with lower the demand", "It was environmentally sound"), two cited money ("Free money", "I always like to save money on bills"), one referenced control issues ("Much better than peak program previously offered as one has more control"), one wanted the thermostat ("I had old thermostat, which was not function accurately"), and one mentioned energy savings ("I want to be responsible regarding energy savings").

Figure 47 and Figure 48 show that $80 \%$ of the participants were satisfied with their experience with the Summer Solutions pilot. 


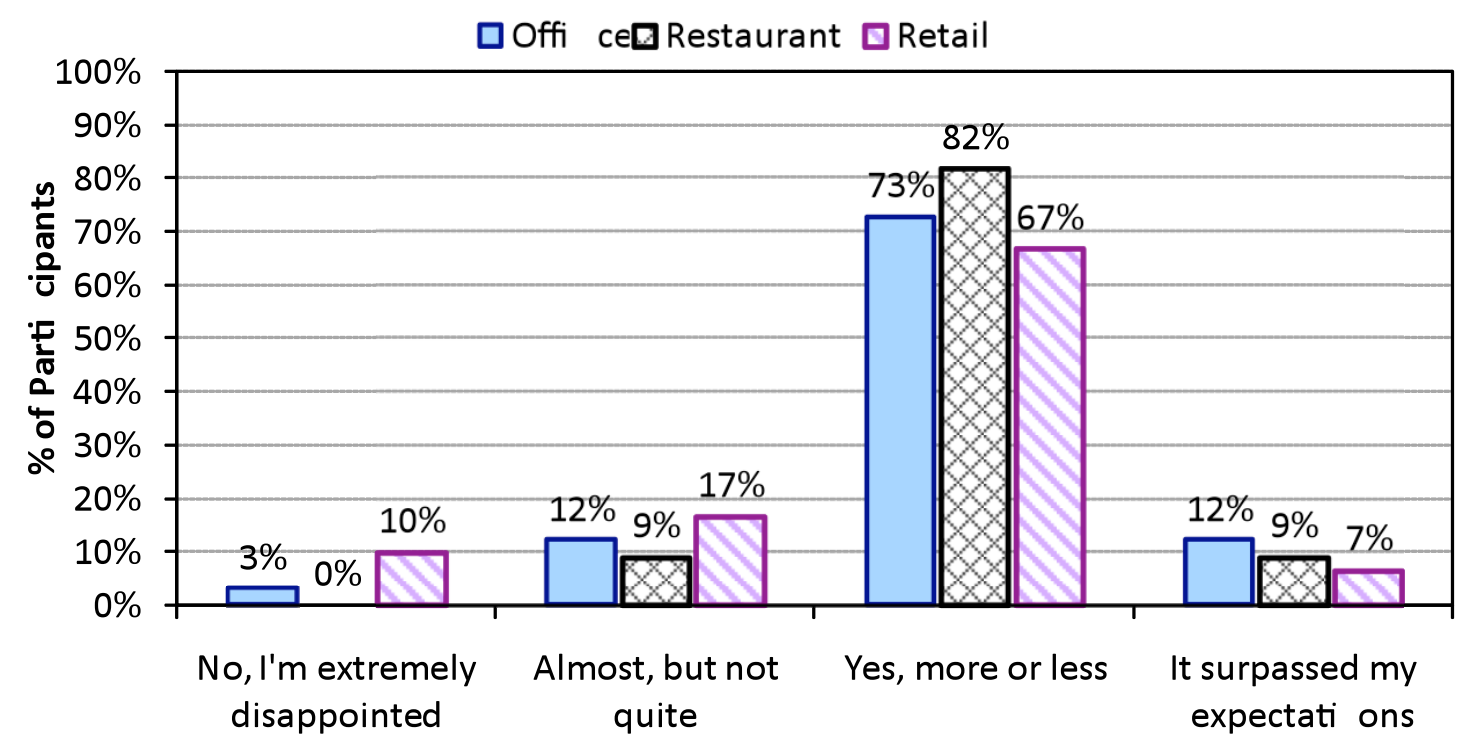

Q2. Did the Summer Soluti ons Program meet your expectati ons

Figure 47. How expectations were met, by business type

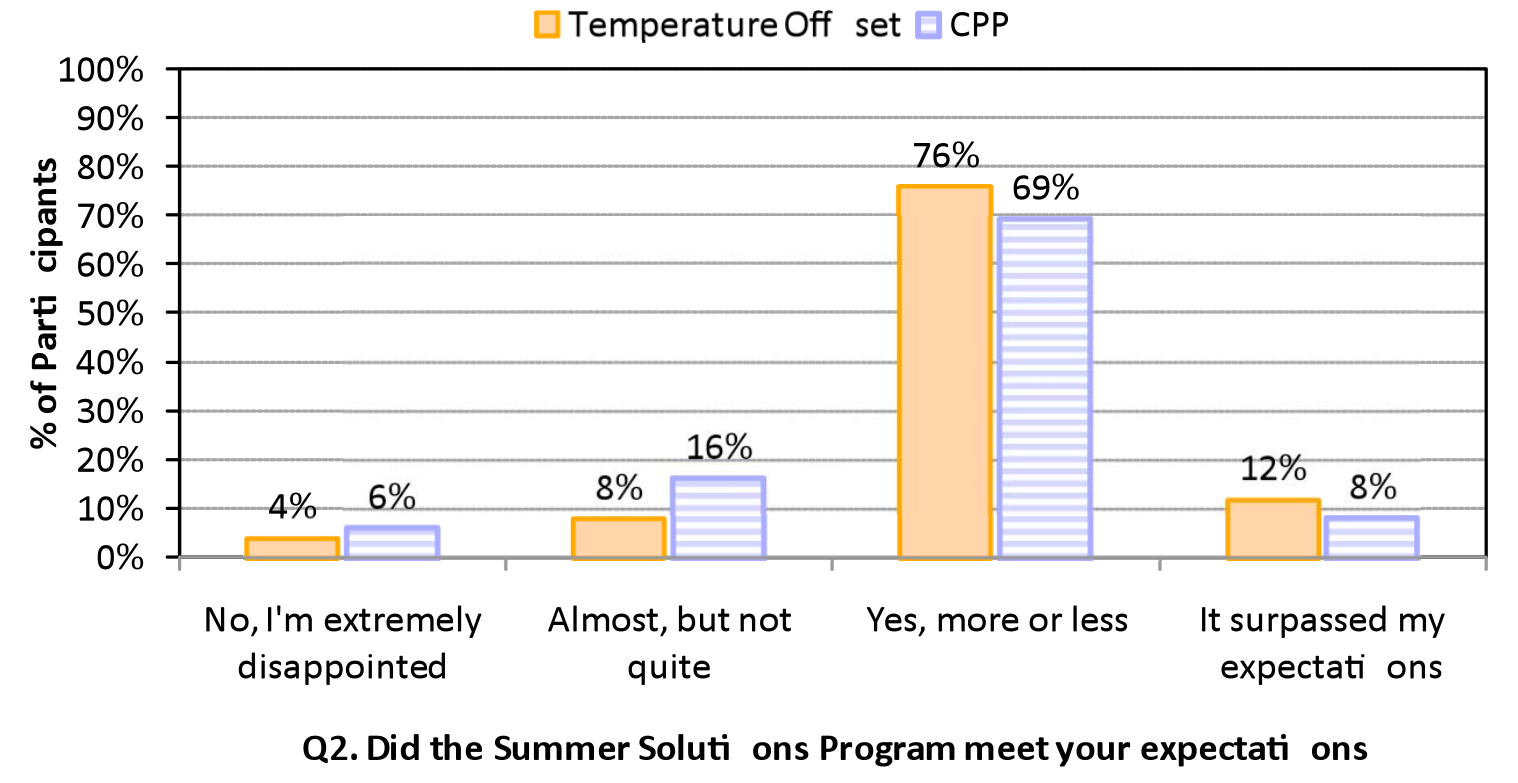

Figure 48. How expectations were met, by program choice 
Satisfaction with the program is also demonstrated by Figure 49 and Figure 50. These graphs show that the majority of participants would be willing to participate in the program again next year, without an additional incentive payment.

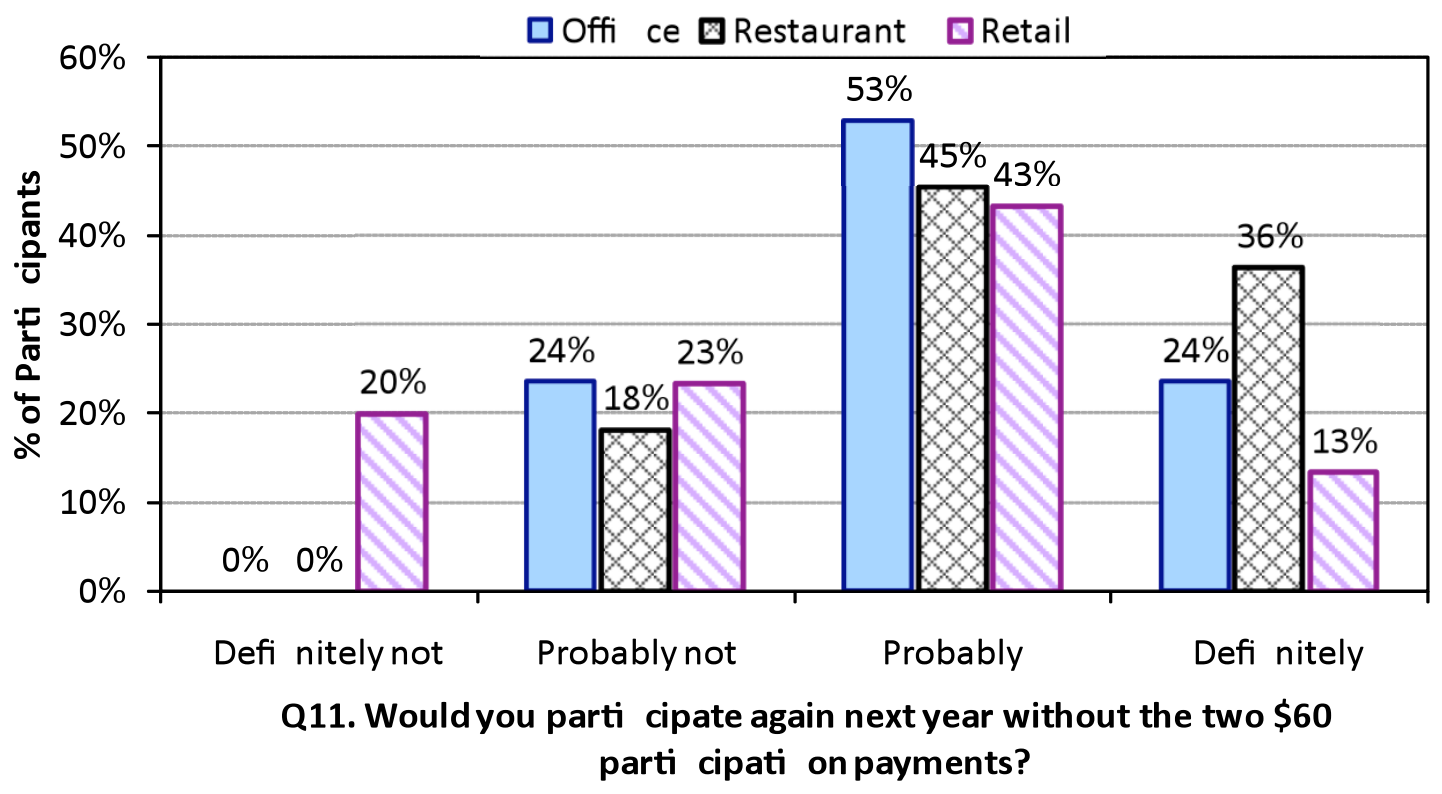

Figure 49. Willingness to participate without participation incentive, by business type

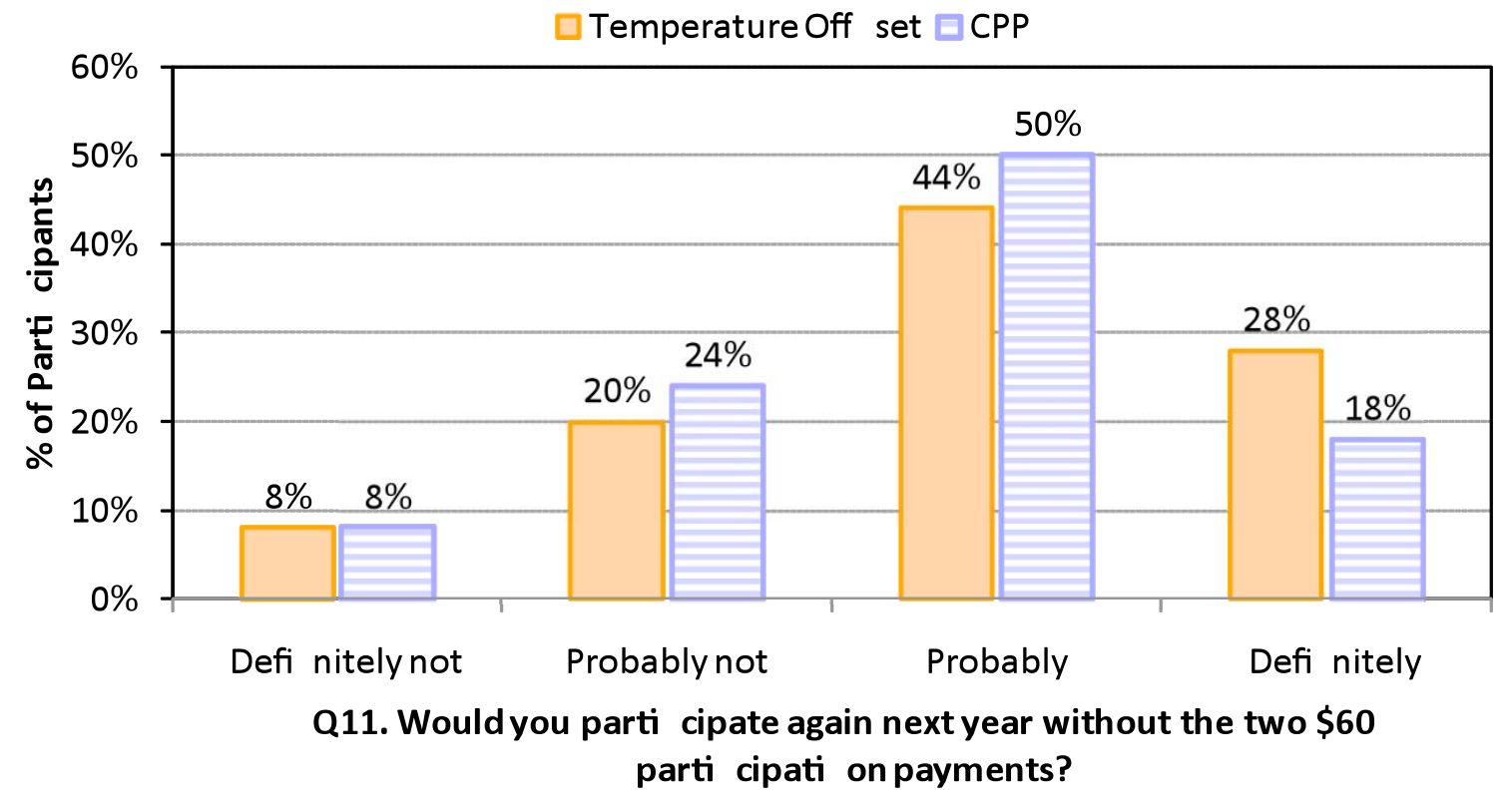

Figure 50. Willingness to participate without participation incentive, by program choice 


\section{Thermostats}

Participants had positive or neutral feedback about the automatic response to events by the PCT, as shown in Figure 51 and Figure 52.

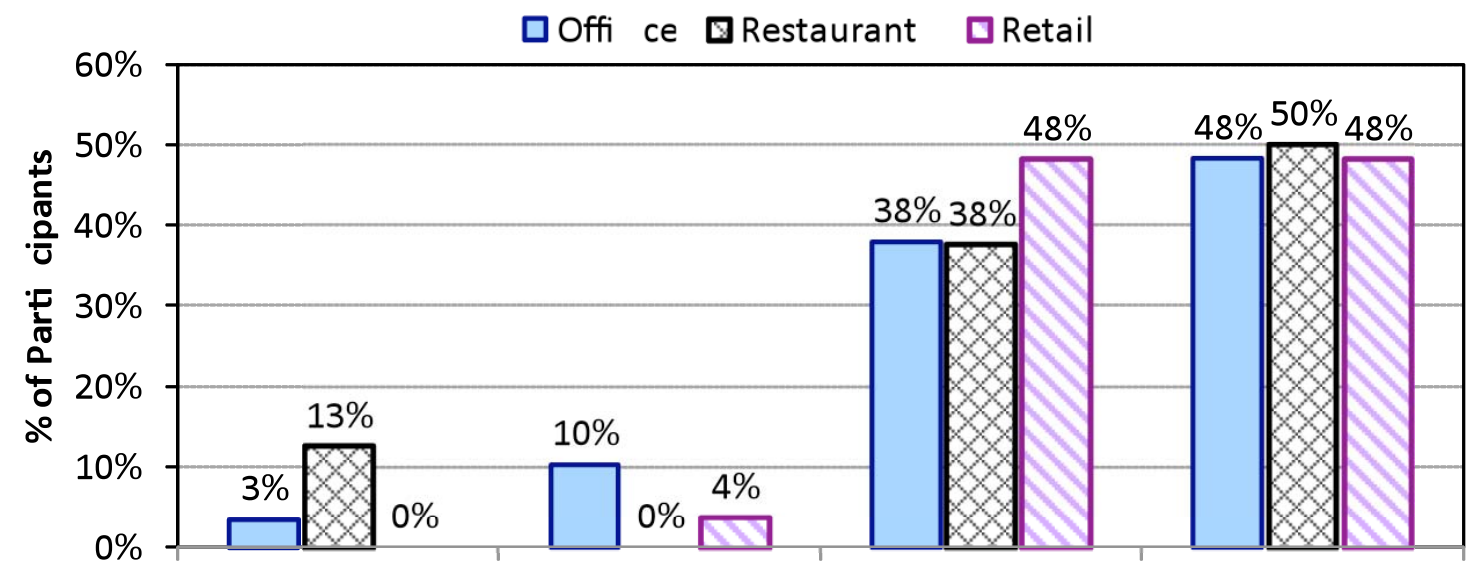

I really didn't like it Was somewhat No strong feeling I really liked it annoyed

Q38. How did you feel about the thermostat's automati c response to events?

Figure 51. Opinion of automatic response, by business type

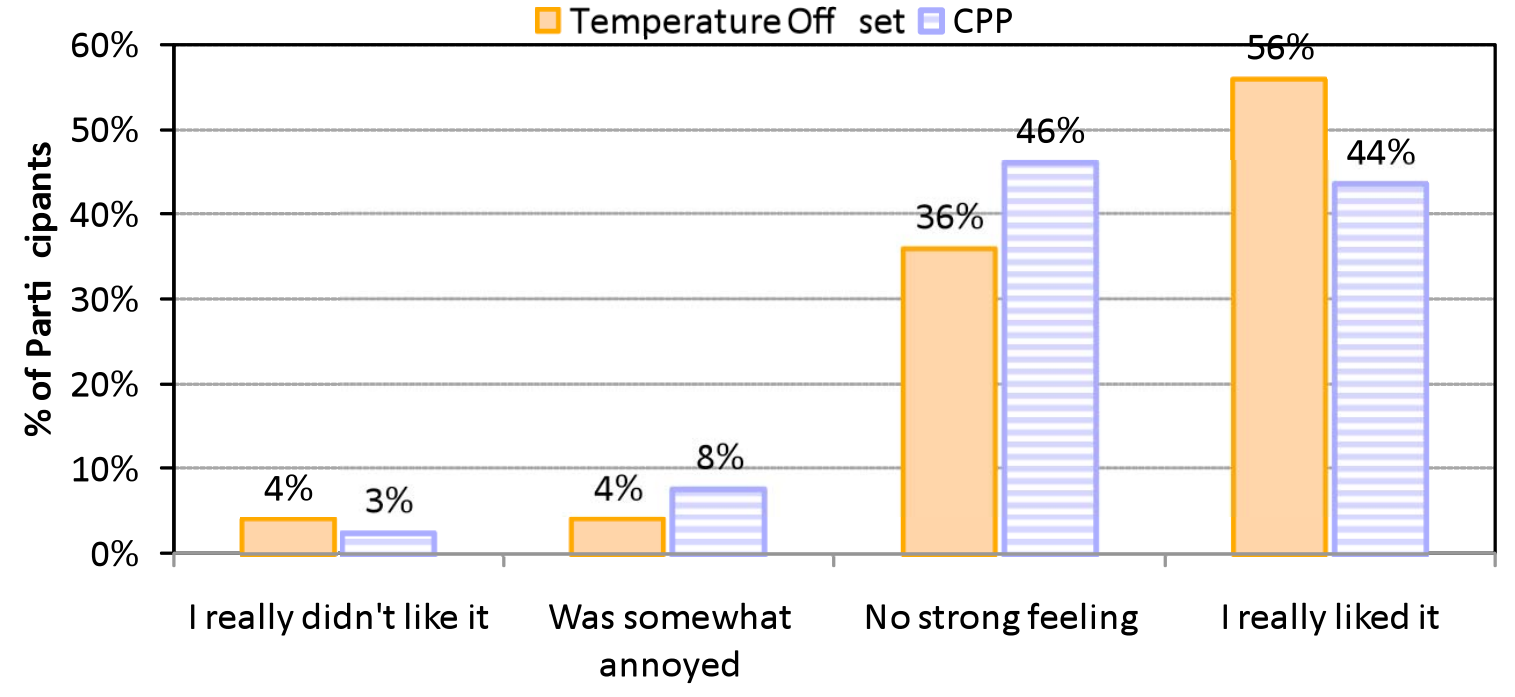

Q38. How did you feel about the thermostat's automati c response to events?

Figure 52. Opinion of automatic response, by program choice 
Most participants also found the new thermostats relatively easy to use, as evidenced in Figure 53 and Figure 54. Two participants did have problems to the extent that they requested their old thermostats back at the conclusion of the pilot.

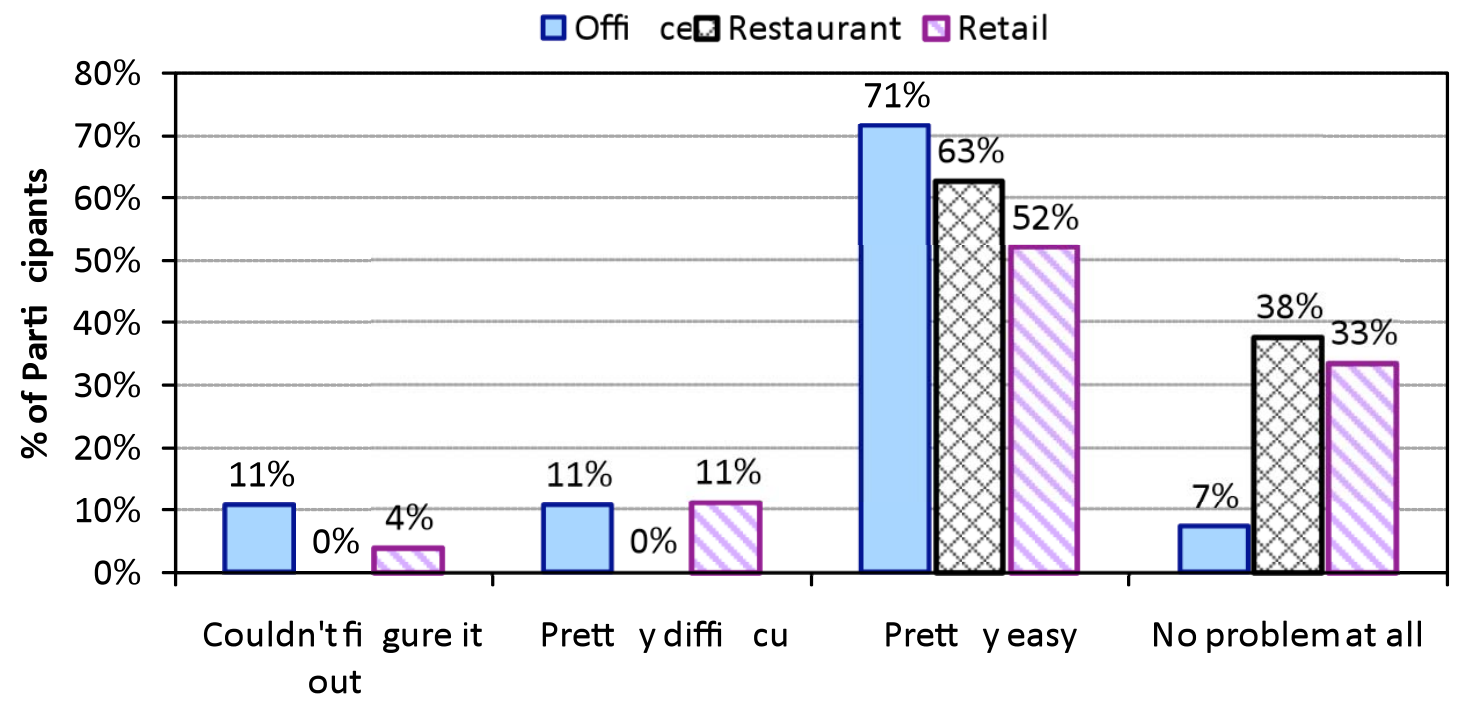

Q33. How easy or diffi cult was the Summer Soluti ons thermostat to work with?

Figure 53. Opinion of thermostat usability, by business type

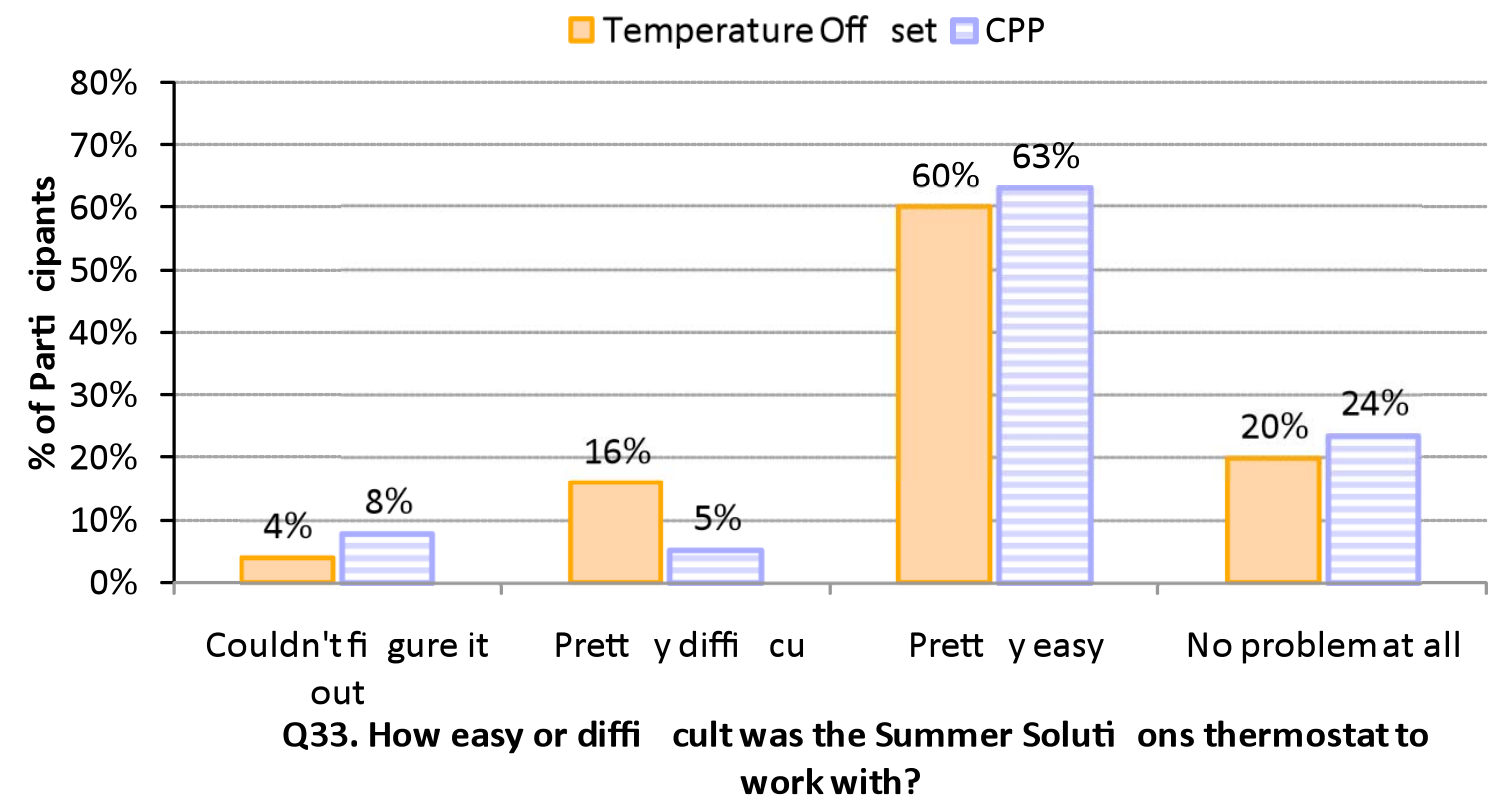

Figure 54. Opinion of thermostat usability, by program choice 
The most popular methods of contact were email and thermostats (Figure 55 and Figure 56). In general, participants preferring phone calls or text message were the ones without internet access or a PCT.

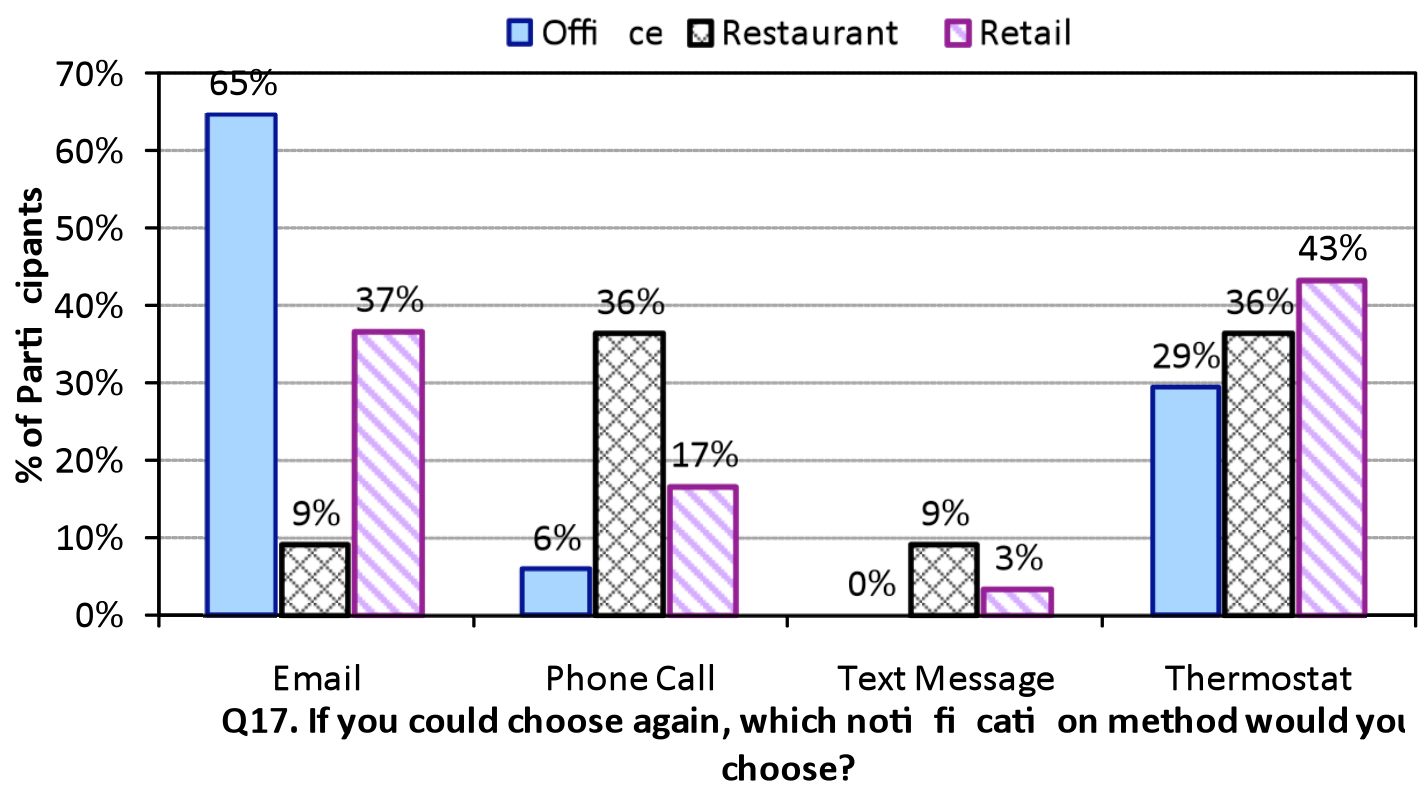

Figure 55. Preferred notification method, by business type

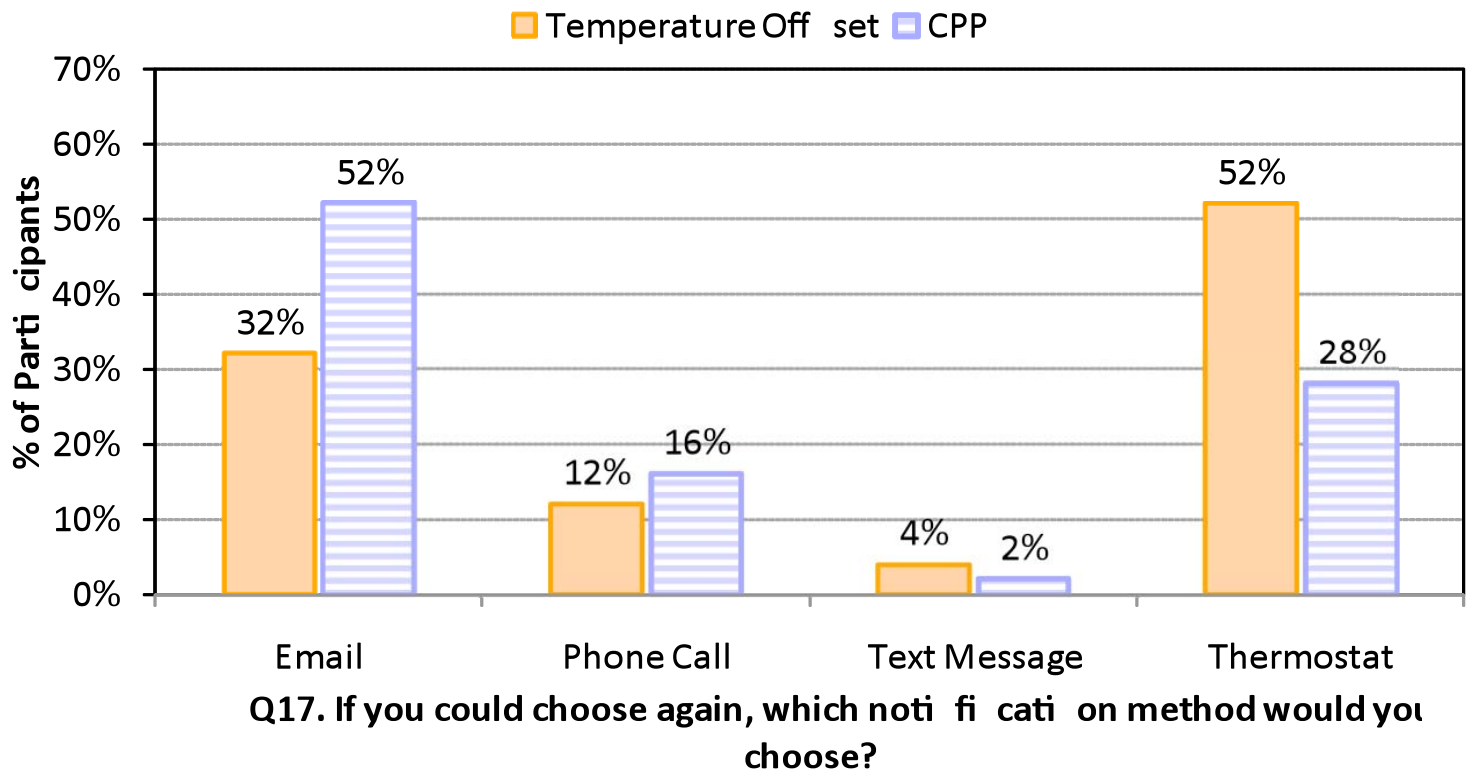

Figure 56. Preferred notification method, by program choice 


\subsection{Conclusions and Recommendations}

We found the Summer Solutions research pilot to be a three-way win, benefiting SMUD, pilot participants, and society in general. SMUD benefited by receiving $20 \%$ peak load reductions on event days, participants benefited from $20 \%$ to $30 \%$ lower bills, and society benefited from the $20 \%$ energy-efficiency savings.

This study provides California State policy makers assurance that dynamic rates and load control programs can be used concurrently and effectively in the small business sector. This study also informs California State energy agencies that it is possible to use Radio Data System communications technology to broadcast system alerts to the mass market in support of dynamic rates, demand response programs, and utility service messages - even in the event of a power outage. Finally, this study provides further evidence that communicating thermostats are a viable demand response technology, capable of automatically increasing setpoints to a customer-determined or utility-determined level, thus providing air-conditioning demand response within seconds or minutes.

We learned many lessons over the course of this study - some expected, some not. Below we provide recommendations for future programs and pilots based on our experience with this study.

Utilities should not hesitate to target the small commercial sector, in particular small offices and retail shops, for integrated EE-DR programs.

As hoped, the office and retail participants in this study precooled before events, increased setpoints during events, and shifted load away from the peak hours. Although the restaurants participating in this study changed thermostat settings to precool and offset during events, they were unable to drop load because their air-conditioning units were undersized.

Demand response programs should provide participants with energy efficiency assistance especially envelope enhancements.

Customers want help with the efficiency of their buildings. Providing assistance in the form of audits, information and/or rebates can be used to entice customers to participate. Efficiency improvements to the building shell will also reduce the comfort effects associated with thermostat setpoint changes during CPP or ACC events, since a better insulated building will retain its temperature longer than would its less insulated counterpart.

Small commercial demand response program offerings should give customers a choice between a dynamic rate and load/temperature control.

This recommendation is based on two findings. First, in the focus groups, some participants preferred the CPP rate for its flexibility, while others preferred the AC control program for its ease of use. This preference split was further supported by the actual program uptake rates of one-third ACC and two-thirds CPP. Since both incentive structures were preferred by such large fractions of the sample population, one would expect that the offering of both incentive structures would results in higher participation rates and happier customers.

Second, both the $4^{\circ}$ ACC and CPP programs provided significant and similar load impacts during events. Thus, from the standpoint of load impacts, there is no strong reason for a utility 
to prefer one over the other. In this study, the $2^{\circ} \mathrm{ACC}$ was a less popular program option and provided less response. On a larger scale, this option could still be a viable alternative for those customers unwilling to shed a full $4^{\circ}$, however, the cost effectiveness of this option should be carefully considered in the context of both efficiency and demand response benefits, since the demand response benefits alone are less likely to justify the cost of the communicating thermostat.

\section{SMUD should seriously consider expanding this voluntary program model to all of their} small commercial customers.

If SMUD is searching for opportunities to simultaneously improve efficiency and demand response in the District, we recommend that they consider the expansion of the Summer Solutions pilot to the general small business customer population on a voluntary basis. Given the results of this study and current pace of communicating thermostat cost reduction, we expect a combination demand response and efficiency program like the Summer Solutions program to be one of the most cost-effective options available. Even so, a cost-benefit analysis of such an expansion is recommended. 


\subsection{BIBLIOGRAPHY}

1. Boice Dunham Group, Additional Peak Load Control Technologies for Small-Medium Business Customers. 2006, Southern California Edison: New York, NY.

2. Braun, James E. and Lee, Kyoung-Ho. 2005. “Assessment of Demand Limiting using Building Thermal Mass in a Small Commercial Building." Proof. CH-06-7-2. ASHRAE.

3. Charles River Associates, California's Statewide Pricing Pilot: Commercial \& Industrial Analysis Update. 2006.

4. Conservation Council of Ontario. 2006. Doors Closed Ontario. We Conserve. Partial documentation available at http://www.weconserve.ca/doorsclosed/.

5. Janda, Kathryn, Christopher Payne, Rick Kunkle, and Loren Lutzenhiser. 2002. “What Organizations Did (and Didn't) Do: Three Factors that Shaped Conservation Responses to California's 2001 'Crisis'." In Proceedings of the 2002 ACEEE Summer Study on Energy Efficiency in Buildings. Pacific Grove, CA. American Council for an Energy-Efficient Economy. Washington, D.C. Downloadable at http:/ / www.osti.gov/bridge/ purl.cover.jsp?purl=/832750-cLhbNi/native/

6. Geltz, Christine, and Mark S. Martinez. 2004. "Diffusion in the Desert: Adoption of Demand Response Technology by Rural Small Business." In Proceedings of the 2004 ACEEE Summer Study on Energy Efficiency in Buildings. Pacific Grove, CA. American Council for an Energy-Efficient Economy. Washington, D.C

7. Goldman, Charles, Nicole Hopper, Osman Sezgen, Mithra Moezzi, Ranjit Bharvirkar, Bernie Neenan, Dick Boisvert, Pete Cappers, and Donna Pratt. 2004. Customer Response to Dayahead Wholesale Market Electricity Prices: Case Study of RTP Program Experience in New York. LBNL-54761. June. Lawrence Berkeley National Laboratory.

8. Lee, Kyoung-Ho and James E. Braun. 2005. “An Experimental Evaluation of Demand Limiting Using Building Thermal Mass in a Small Commercial Building." 3 November 2005. ASHRAE.

9. Lutzenhiser, Loren, Kathryn Janda, Rick Kunkle, and Christopher Payne. 2002. Understanding the response of commercial and institutional organizations to the California Energy Crisis. Consultant Report. 24 July. 400-02-0180. California Energy Commission. Sacramento, CA.

10. Lockheed Martin Aspen. 2006. Demand Response Enabling Technologies for Small-Medium Businesses. A Technical Report Prepared in Conjunction with the 2005 California Statewide Pricing Pilot. R.02.06.0001. April 12. Prepared for Mark S. Martinez, Southern California Edison Company.

11. Merilatt, Don. 2007. "Pricing for Demand Response from Residential and Small Commercial Customers." Cannon Technologies/Cooper Power Systems. April 2007.

12. Messenger, Mike. 2006. "Proposed Policies to Increase the Level of Demand Response," Power Point Presentation, 24 April, Energy Action Plan. Sacramento, CA.

13. Momentum Market Intelligence, Statewide Pricing Pilot: End-of-Pilot Participant Assessment. 2004.

14. Payne, Christopher. 2006. "The Small Commercial Energy Consumer: About Whom are We Speaking?" In Proceedings of the 2006 ACEEE Summer Study on Energy Efficiency in Buildings. American Council for an Energy Efficient Economy. Washington, D.C.

16. Peak Load Management Alliance. 2002. Demand Response: Design Principles for Creating Customer and Market Value. November.

17. Piette, Mary Ann, David S. Watson, Naoya Motegi, Sila Kiliccote, and Eric Linkugel. 2006. "Participation through automation: Fully automated Critical Peak Pricing in 
Commercial Buildings." In Proceedings of the 2006 ACEEE Summer Study on Energy Efficiency in Buildings. American Council for an Energy-Efficient Economy. Washington, D.C.

18. Quantum Consulting, 1999. BEMS Market Effects Study Final Report.

19. Quantum Consulting. 2001. Statewide Small/Medium Non-Residential Customer Needs and Wants Study.

20. RLW Analytics. 2005. Program Impact Evaluation of the 2004 SCE Energy\$mart Thermostat Program. Southern California Edison. Sonoma, CA

22. Summit Blue Consulting. 2006. "Process evaluation of selected California 2005 Demand Response Education, Awareness, and Outreach Programs." April 27.

23. Wright, Paul. 2007. "Information Technology for the Support of Behavior Change in Energy Usage" (presentation). Center for Information Technology Research in the Interest of Society (CITRIS). U.C. Berkeley. Available at http:/ / piee.stanford.edu/cgibin/docs/behavior/becc/4A-Wright.pdf 


\subsection{APPENDICES}




\section{Appendix A: Thermostat Functionality}




\section{Appendix A: Thermostat Functionality}

This appendix describes the functionality of the communicating thermostats purchased for this pilot. There are three sections, one describing each type of event used in this pilot. Message events were used for all participants, price events were used for the CPP participants, and temperature change events were used for the ACC participants.

\section{Message Event}

When a message event is chosen, the interface prompts for a message to send. The message is displayed on the PCTs belonging to the chosen group during the time specified or until any button is pressed.

Figure 57 shows the entries made during a test message event. The message "text message test" was transmitted two times to increase the probability of successful receipt by the Programmable Communicating Thermostat, and set to appear 17 April 2008 at 16:03 and clear 17 April 2008 at 16:04. Figure 58 shows the Programmable Communicating Thermostat displaying the message.

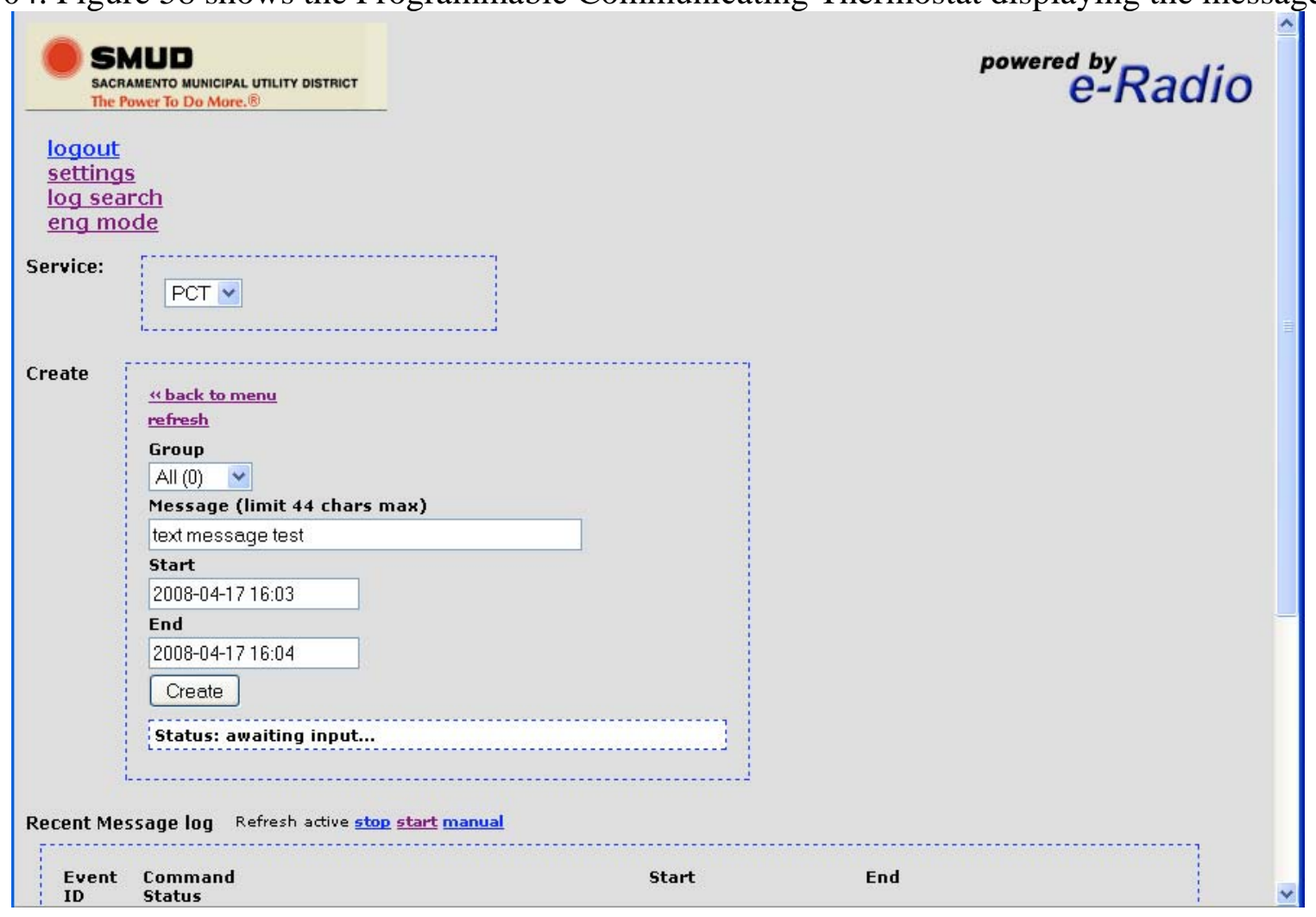

Figure 57. Website Interface for a Message Event 


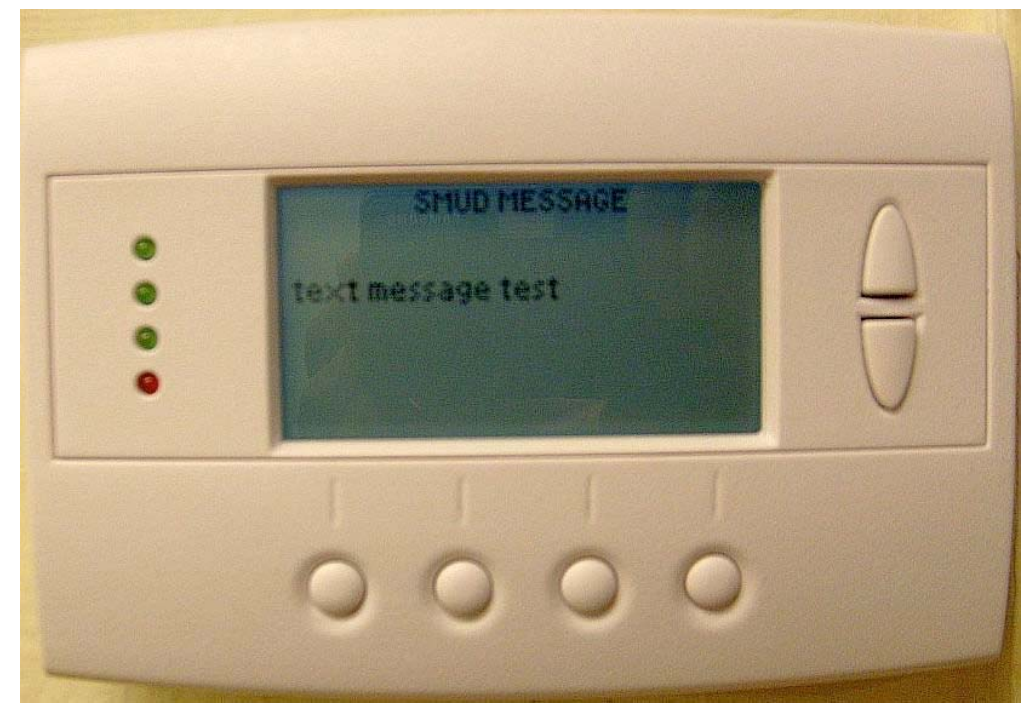

Figure 58. Programmable Communicating Thermostat Displaying a Message

The transmission of the Radio Data system signal was recorded by the eRadio server at the transmission tower site.

The reception of the Radio Data System signal was recorded by the Radio Data System logger which is connected to the Programmable Communicating Thermostat. This log shows that the signal was received at 16:01:30 ${ }^{2}$ and that the message was displayed on the Programmable Communicating Thermostat from 16:03:01 to 16:04:01.

04/17/2008 16:01:30> DL485: Added Message 1: text message test

04/17/2008 16:01:30> DL485: - Start:04/17/2008 16:03:00

04/17/2008 16:01:30> DL485: - Stop: 04/17/2008 16:04:00

04/17/2008 16:03:01> DL485: Message 1 Activated

04/17/2008 16:04:01> DL485: Removed Message 1

\footnotetext{
${ }^{2}$ Testing immediately prior to these results showed that the time on the receiver log was 8 seconds different than the time on the eRadio server log. The times in the receiver logs have been modified to reflect this.
} 


\section{Price Event}

When a price event is chosen, the interface prompts for a price tier. The current system allows for price tiers 1 through 4, but could easily be programmed to accommodate more. Electricity prices corresponding to each tier must be set by utilities in advance. For this project, when Tiers 1-3 are selected, the PCTs will simply display the current price. For Tier 4, PCTs will (a) immediately warn customers of the impending price event, (b) initiate a pre-cooling strategy (if any) on the morning of the event, and (c) initiate the response strategy (if any) at the onset of the event. Customers will also be notified when the event ends. Figure 59 shows the entries made during a test price event. The critical peak (Tier 4) event was transmitted two times to increase the probability of successful receipt by the Programmable Communicating Thermostat, and set to start 17 April 2008 at 16:12 and end 17 April 2008 at 16:16.

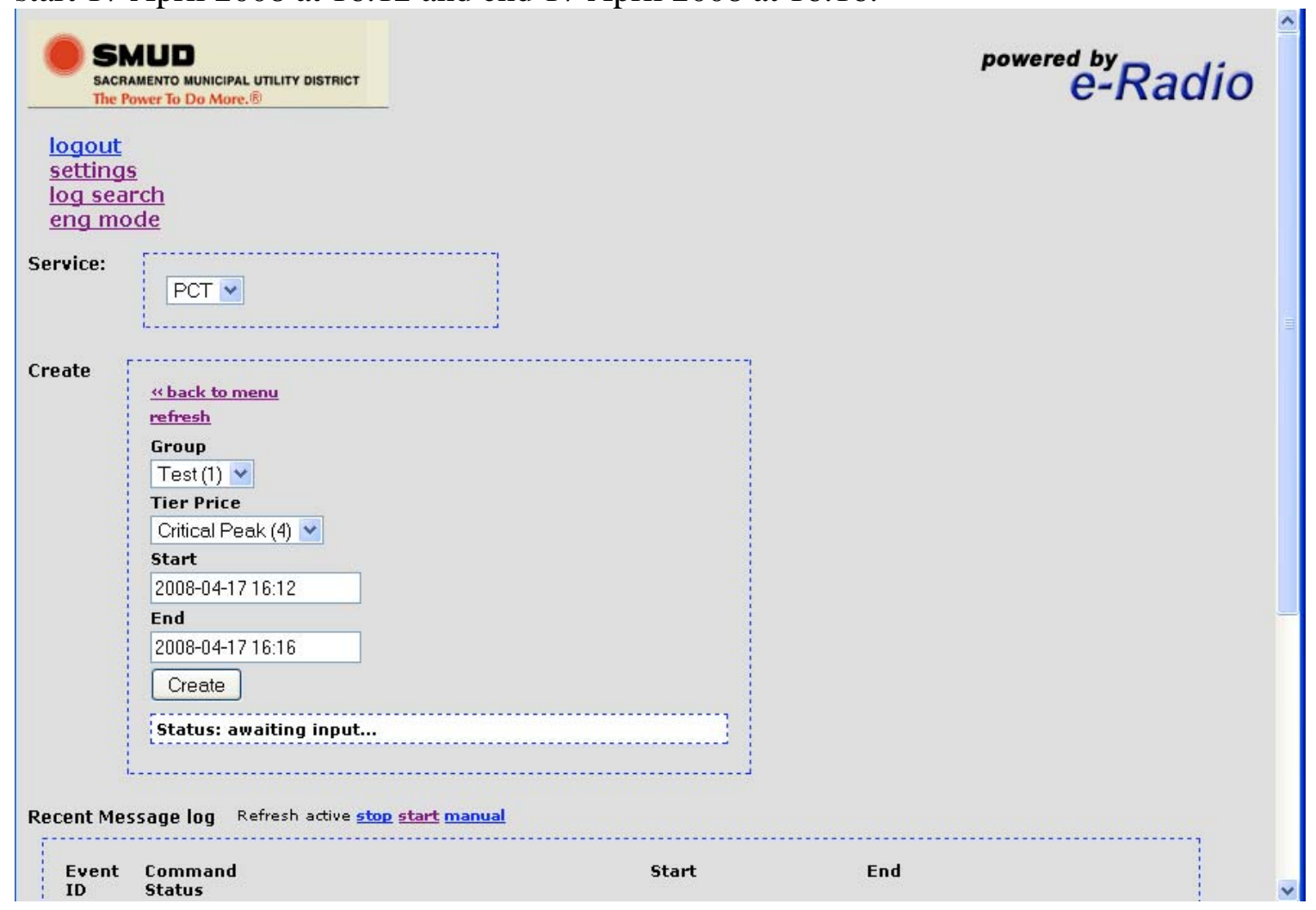

Figure 59. Website Interface for a Price Event 
When the Tier $=4$, the flashing notice shown in Figure 60 is displayed until any button is pressed.

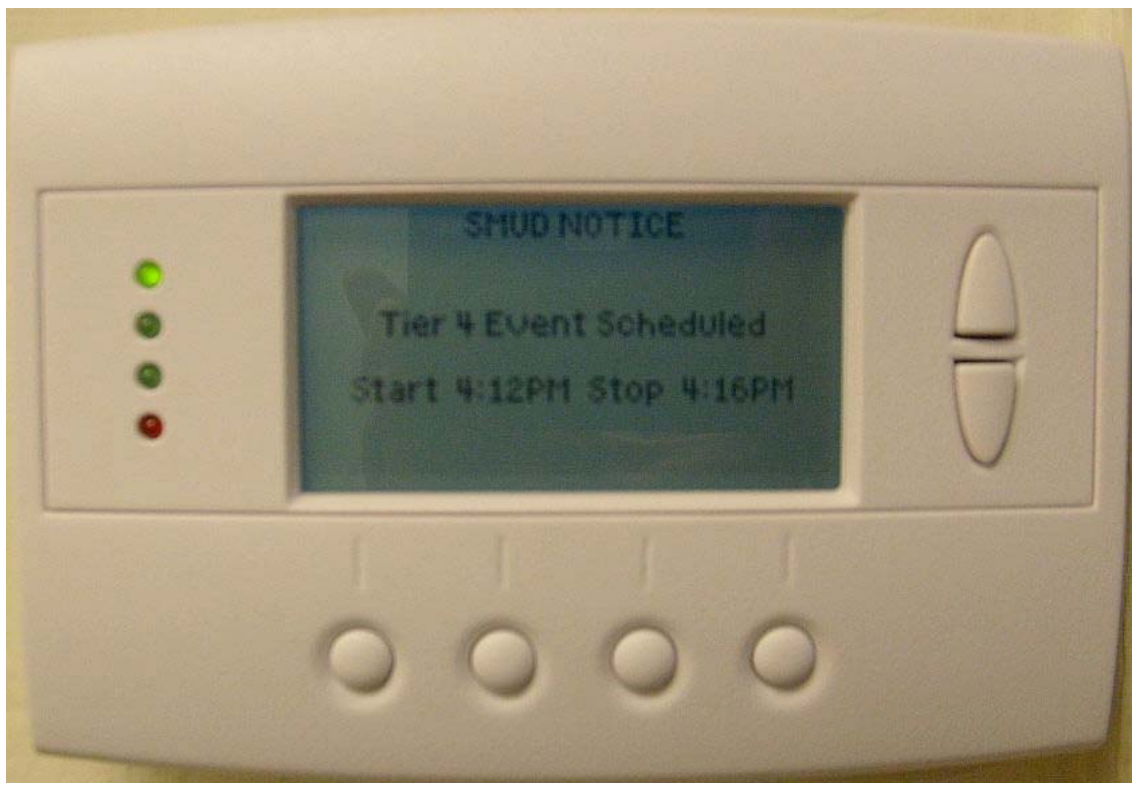

Figure 60. Programmable Communicating Thermostat Displaying Tier 4 Notice

After a button is pressed to acknowledge the event, the current settings are displayed as shown in Figure 61 . The cooling set point, shown on the right side of the display, is $76^{\circ} \mathrm{F}$ and the thermostat is in RUN mode-the AC unit is on.

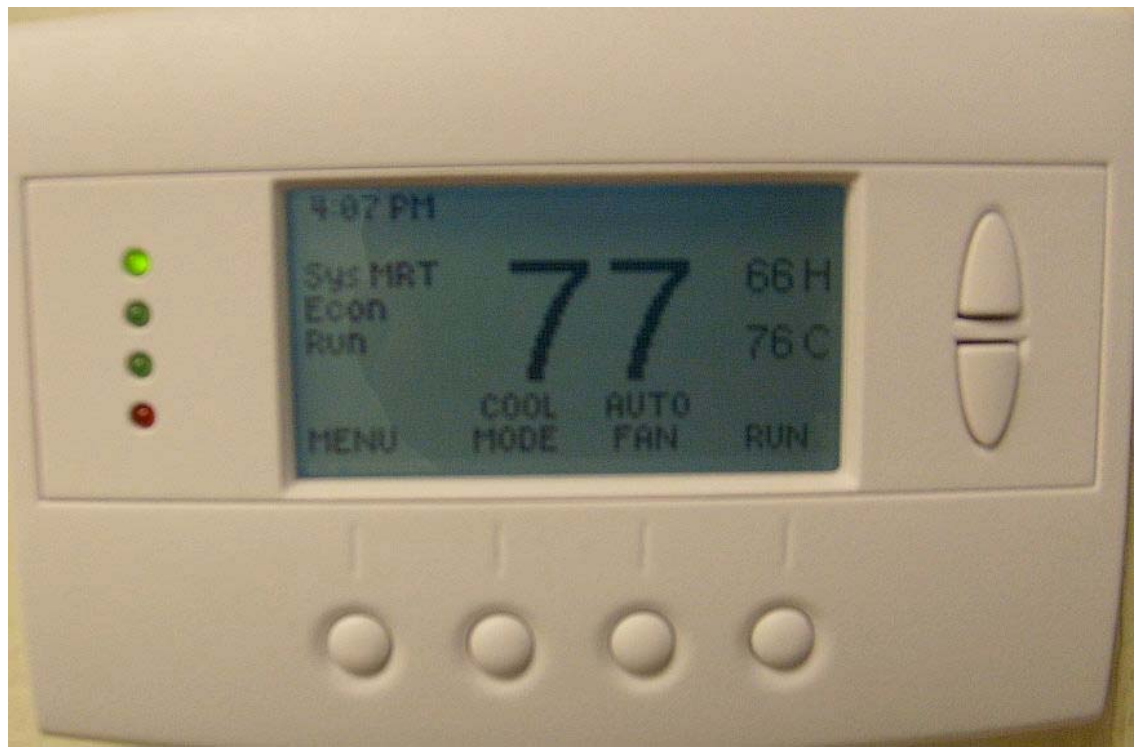

Figure 61. Programmable Communicating Thermostat Showing Current Settings Before Tier 4 Event 
At the beginning of the event the Programmable Communicating Thermostat displays a flashing screen as shown in Figure 62 until any button is pressed.

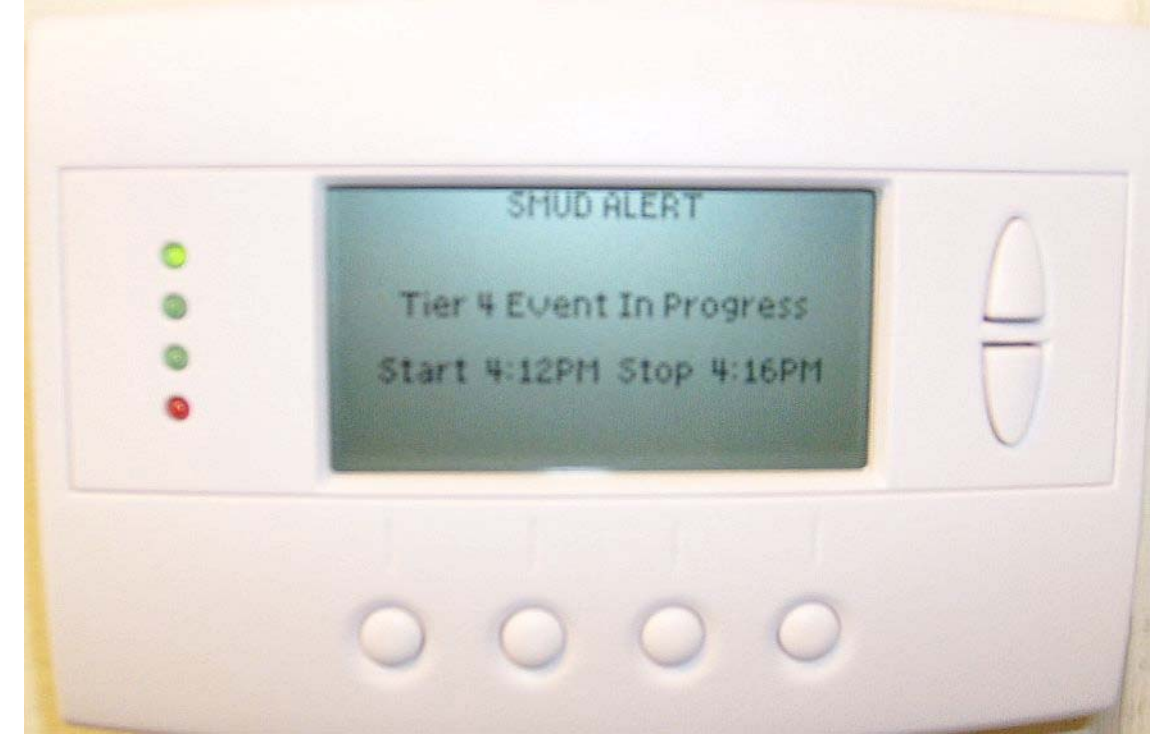

Figure 62. Programmable Communicating Thermostat Displaying Tier 4 Event in Progress

This particular thermostat is programmed to respond to a Tier 4 price event with a 4 degree temperature offset. Note that the cooling temperature set point in Figure 63 has changed from $76^{\circ} \mathrm{F}$ to $80^{\circ} \mathrm{F}$ and the thermostat has changed from RUN to HOLD mode-the AC unit is off.

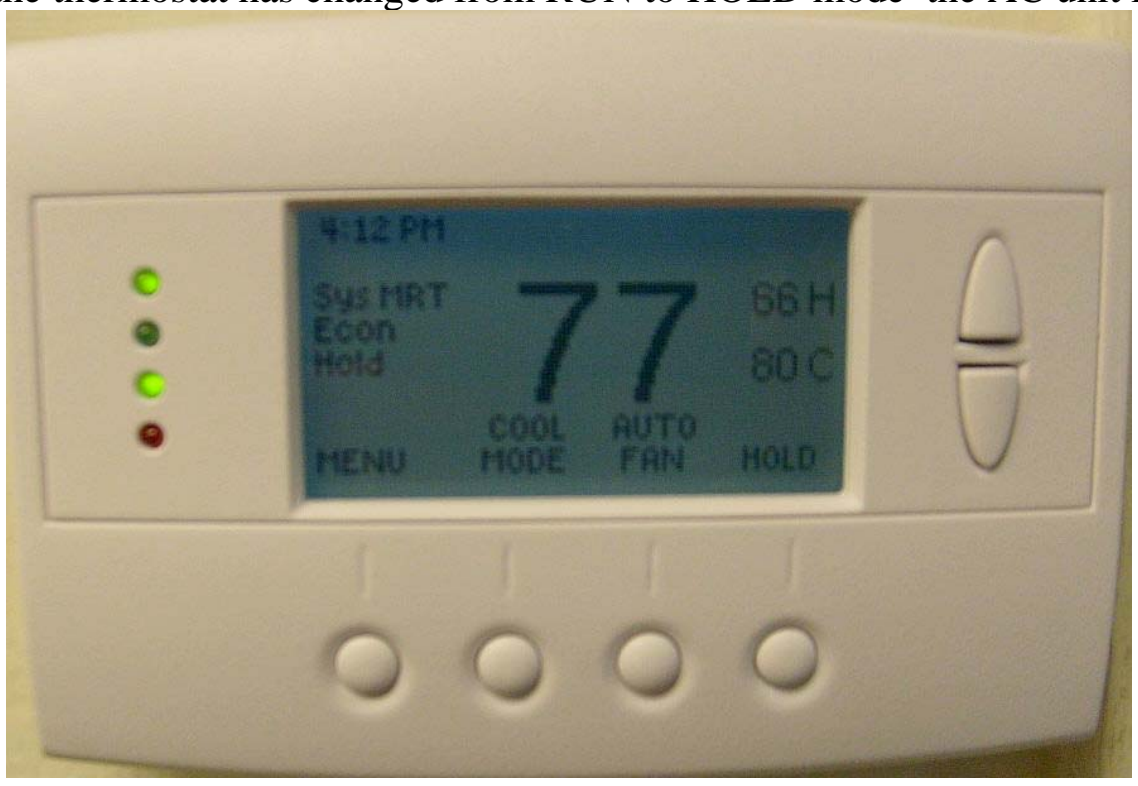

Figure 63. Programmable Communicating Thermostat Showing Current Settings During a Tier 4 Price Event 
At the end of the event, the Programmable Communicating Thermostat returns to normal programming and displays the flashing screen shown in Figure 64 until any button is pressed.

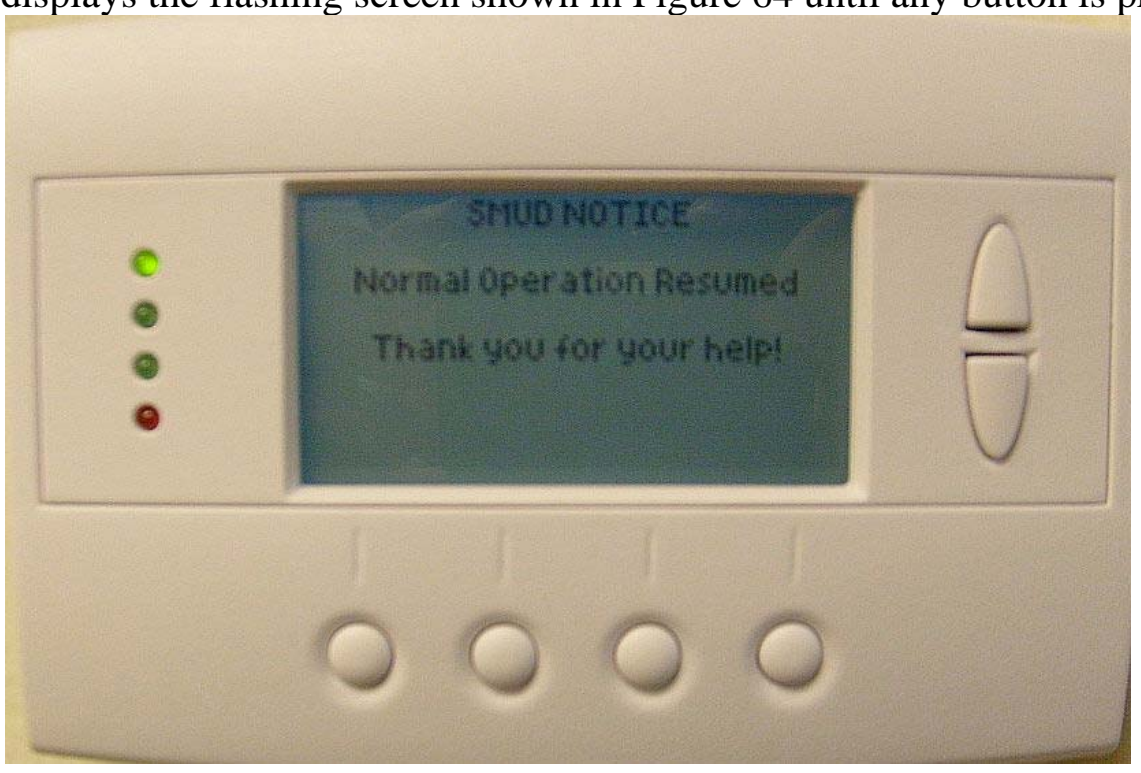

Figure 64. Programmable Communicating Thermostat Displaying End of Price Event Message

The transmission of the Radio Data System signal was recorded by the eRadio server at the transmission tower site. The price event signal required 4 groups (shown in the log as packets) and was repeated twice for a total length of 8 groups. The log for this event shows that the signal transmission started at 16:07:55 and ended at 16:08:03, for a total transmission time of 8 seconds.

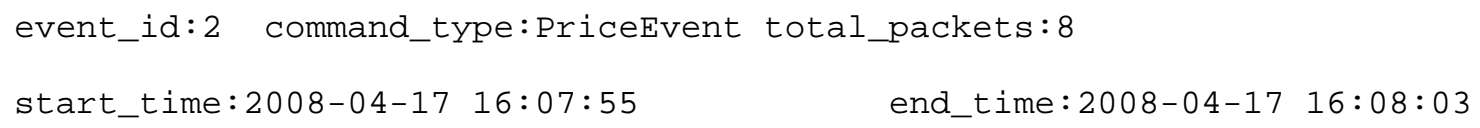

The reception of the Radio Data System signal was recorded by the Radio Data System logger which is connected to the Programmable Communicating Thermostat. This log shows that the signal was received at 16:08:00 and that the event lasted from 16:12:02 to 16:16:02.

04/17/2008 16:08:00> DL485: Added Event 2: Price, Tier:4.000000

04/17/2008 16:08:00> DL485: - Start: 04/17/2008 16:12:00

04/17/2008 16:08:00> DL485: - Stop: 04/17/2008 16:16:00

04/17/2008 16:12:02> DL485: Event 2 Activated

04/17/2008 16:16:02> DL485: Removed Event 2 


\section{Temperature Change Event}

When a Temperature Change event is chosen, the interface prompts for an offset. On receiving the signal, PCTs (a) immediately warn customers of the impending curtailment event, (b) initiate the pre-cooling strategy (if any) on the morning of the event, and (c) initiate the response strategy at the onset of the event. Customers are also notified when the event ends.

Figure 65 shows the entries made during a test temperature change event. The message was repeated twice to increase the probability of successful receipt by the Programmable Communicating Thermostat. The event was set to start on 17 April 2008 at 16:22 and end on 17 April 2008 at 16:26 with a temperature offset of $5^{\circ} \mathrm{F}$.

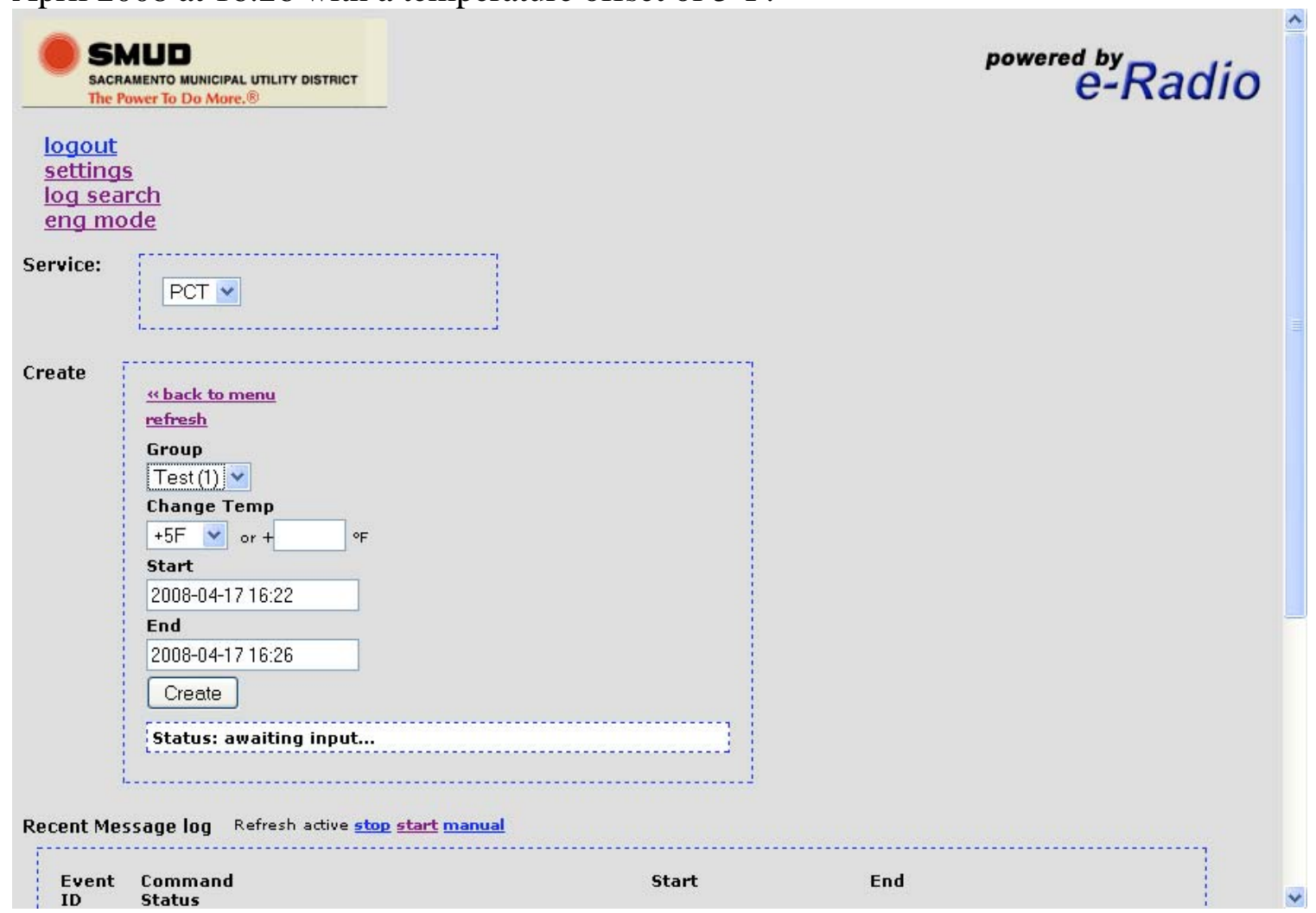

Figure 65. Website Interface for a Temperature Change Event 
When the Temperature Change notice is received, the Programmable Communicating Thermostat displays a flashing notice as shown in Figure 66 until any button is pressed.

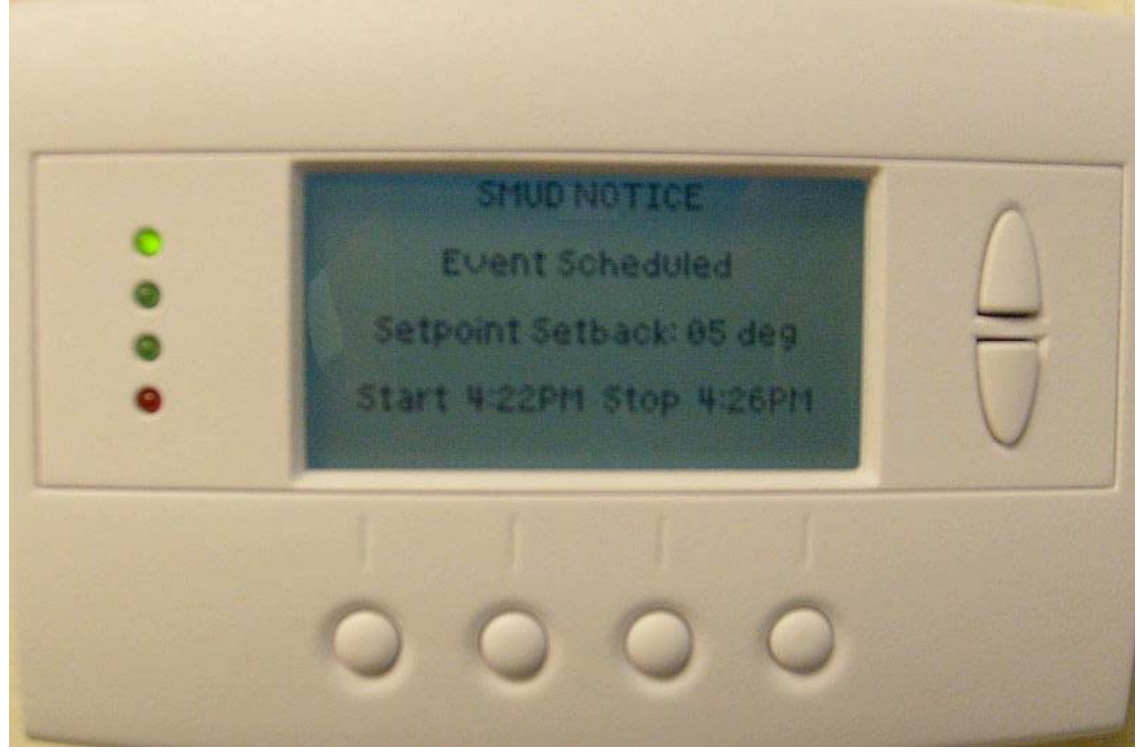

Figure 66. Programmable Communicating Thermostat Displaying Temperature Change Notice

After a button is pressed to acknowledge the event, the current settings are displayed as shown in Figure 67. The cooling set point is $76^{\circ} \mathrm{F}$ and the thermostat is in RUN mode-the AC unit is on.

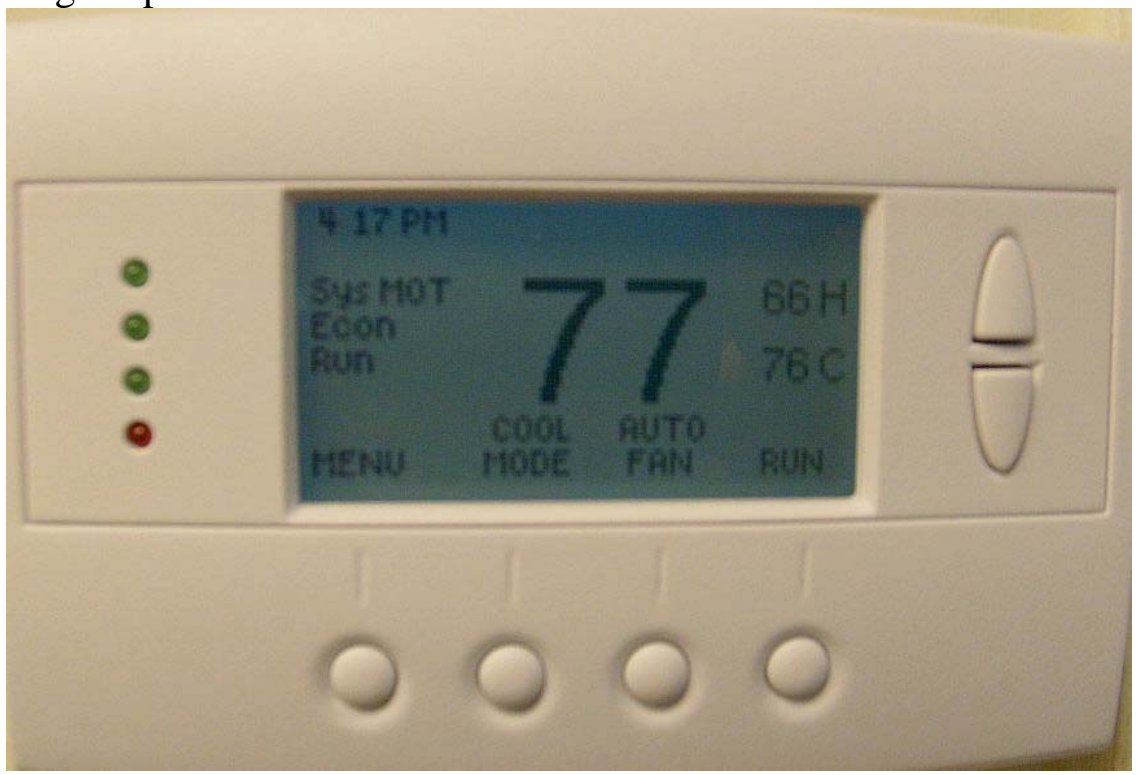

Figure 67. Programmable Communicating Thermostat Displaying Current Settings Before Temperature Event 
When the event begins, the Programmable Communicating Thermostat displays a curtailment alert as shown in Figure 68 and changes the setpoint temperature according to the instructions received.

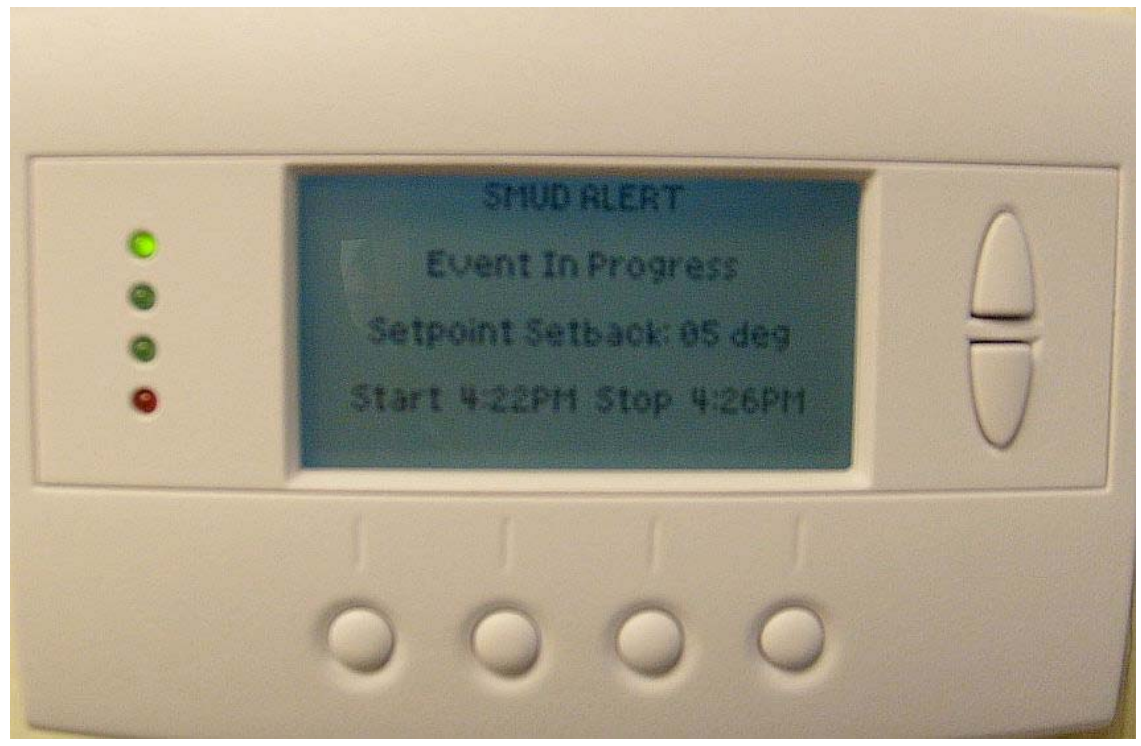

Figure 68. Programmable Communicating Thermostat Displaying Ttemperature Event in Progress Notice

After a button is pressed to acknowledge the event, the new settings are displayed as shown in Figure 69. Note that the cooling set point has increased from $76^{\circ} \mathrm{F}$ to $81^{\circ} \mathrm{F}$, the thermostat has changed from RUN to HOLD mode, and the AC unit is off.

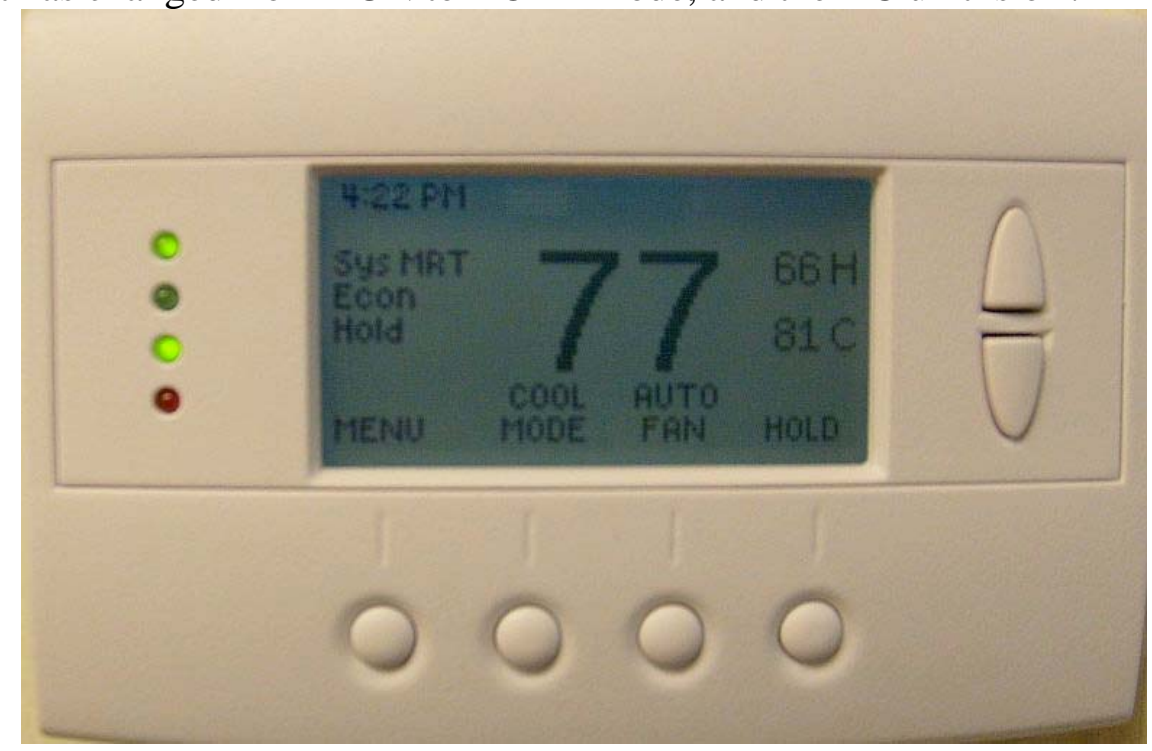

Figure 69. Programmable Communicating Thermostat Displaying Current Settings During Temperature Event 
At the end of the event, the Programmable Communicating Thermostat returns to normal programming and displays a flashing notice as shown in Figure 70 until any button is pressed.

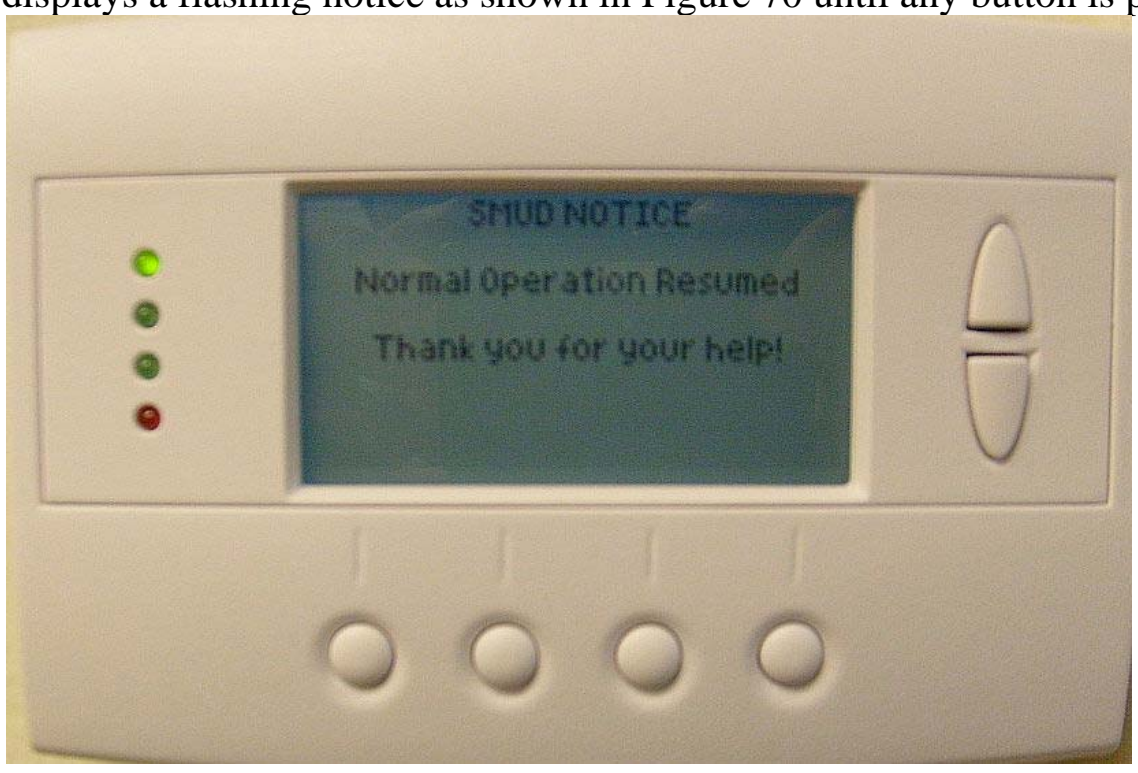

\section{Figure 70. Programmable Communicating Thermostat Displaying End of Temperature Event} Notice

The transmission of the Radio Data System signal was recorded by the eRadio server at the transmission tower site. The temperature change event signal was four groups (shown in the log as packets) long and repeated twice for a total length of 8 groups. The log for this event shows that the signal transmission started at 16:19:33 and ended at 16:19:41, for a total transmission time of 8 seconds.

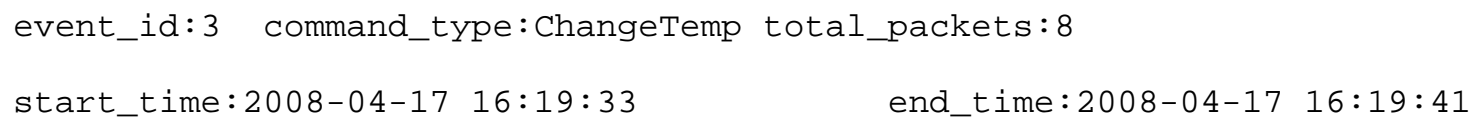

The reception of the Radio Data System signal was recorded by the Radio Data System logger which is connected to the Programmable Communicating Thermostat. This log shows that the signal was received at 16:19:38 and that the event lasted from 16:22:02 to 16:26:02.

04/17/2008 16:19:38> DL485: Added Event 3: Change Temp 5.000000

04/17/2008 16:19:38> DL485: - Start: 04/17/2008 16:22:00

$04 / 17 / 2008$ 16:19:38> DL485: - Stop: 04/17/2008 16:26:00

04/17/2008 16:22:02> DL485: Event 3 Activated

04/17/2008 16:26:02> DL485: Removed Event 3 


\section{Appendix B: Survey Questions and Summary of Answers}




\section{Appendix B: Survey Questions and Summary of Answers \\ Spring (Pre-Experiment) Survey}

Business Information

1. What is your preferred notification method?

\begin{tabular}{|l|r|r|r|r|}
\hline Program Choice & Email & Phone Call & Text Message & Thermostat \\
\hline 2 Deg. Offset & 4 & & & 3 \\
\hline 4 Deg. Offset & 15 & & & 5 \\
\hline CPP & 32 & 8 & 1 & 10 \\
\hline
\end{tabular}

\begin{tabular}{|l|l|l|l|l|}
\hline Business Type & Email & Phone Call & Text Message & Thermostat \\
\hline
\end{tabular}

\begin{tabular}{|l|l|l|l|l|}
\hline Office & 27 & 1 & & 7 \\
\hline Restaurant & 4 & 2 & 1 & 5 \\
\hline Retail & 20 & 5 & & 6 \\
\hline
\end{tabular}




\section{Business Hours}

M-F Opening Time

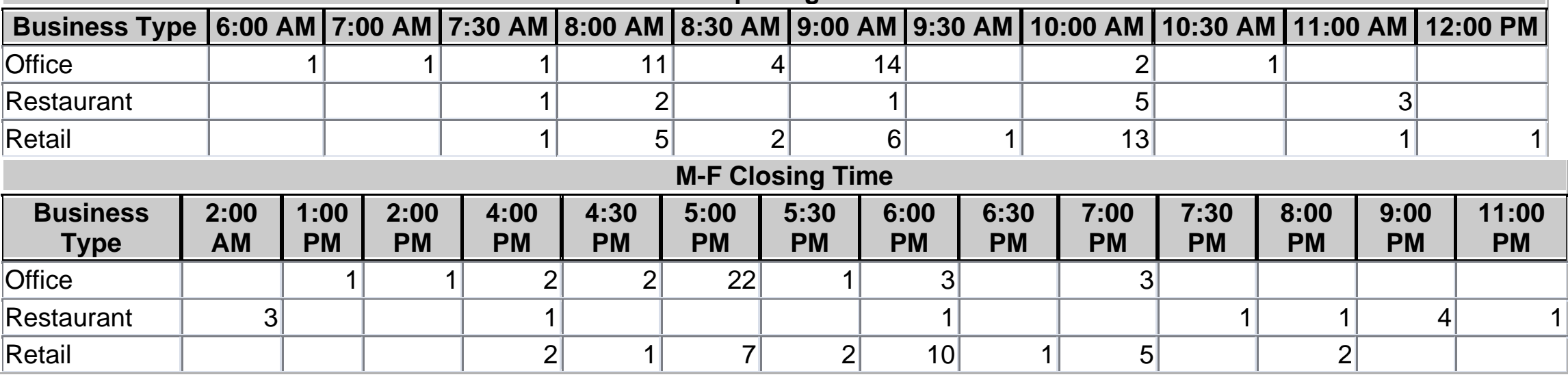

\begin{tabular}{|c|c|c|c|c|c|c|c|c|c|c|c|c|c|c|c|}
\hline \multicolumn{16}{|c|}{ M-F Opening Time } \\
\hline \begin{tabular}{|l|} 
Program \\
Choice
\end{tabular} & $\begin{array}{l}6: 00 \\
\text { AM }\end{array}$ & \multicolumn{2}{|c|}{ 7:00 AM } & $\begin{array}{l}\text { 7:30 } \\
\text { AM }\end{array}$ & $\begin{array}{l}\text { 8:00 } \\
\text { AM }\end{array}$ & $\begin{array}{l}8: 30 \\
\text { AM }\end{array}$ & \multicolumn{2}{|c|}{ 9:00 AM } & $\begin{array}{l}9: 30 \\
\text { AM }\end{array}$ & $\begin{array}{l}10: 00 \\
\text { AM }\end{array}$ & 10:30 Al & & \multicolumn{2}{|c|}{ 11:00 AM } & $\begin{array}{l}\text { 12:00 } \\
\text { PM }\end{array}$ \\
\hline 2 Deg. Offset & & & & & 2 & & & & & 2 & & & \multicolumn{2}{|l|}{3} & \\
\hline 4 Deg. Offset & & & & 1 & 4 & 1 & \multicolumn{2}{|l|}{9} & & 4 & & & & 1 \\
\hline CPP & 1 & 1 & & 2 & 12 & 5 & \multicolumn{2}{|l|}{12} & 1 & 14 & 1 & & \multicolumn{2}{|c|}{1} & \\
\hline \multicolumn{16}{|c|}{ M-F Closing Time } \\
\hline \begin{tabular}{|l|} 
Program \\
Choice
\end{tabular} & $\begin{array}{l}\text { 2:00 } \\
\text { AM }\end{array}$ & \begin{tabular}{|l} 
1:00 \\
PM
\end{tabular} & \begin{tabular}{|l}
$2: 00$ \\
PM
\end{tabular} & $\begin{array}{l}\text { 4:00 } \\
\text { PM }\end{array}$ & \begin{tabular}{|l} 
4:30 \\
PM
\end{tabular} & $\begin{array}{l}\text { 5:00 } \\
\text { PM }\end{array}$ & $\begin{array}{l}\text { 5:30 } \\
\text { PM }\end{array}$ & \begin{tabular}{|l}
$6: 00$ \\
PM
\end{tabular} & \begin{tabular}{|l}
$6: 30$ \\
PM
\end{tabular} & 7:00 PM & 7:30 PM & \multicolumn{2}{|c|}{$\begin{array}{l}\text { 3:00 } \\
\text { गM }\end{array}$} & 9:00 PM & $\begin{array}{l}\text { 11:00 } \\
\text { PM }\end{array}$ \\
\hline 2 Deg. Offset & 1 & & & 1 & & 1 & & 2 & & & & & & 1 & 1 \\
\hline 4 Deg. Offset & & & & & 1 & 12 & & 5 & & 1 & & & & 1 & \\
\hline CPP & 2 & 1 & 1 & 4 & 2 & 16 & 3 & 7 & 1 & 7 & 1 & 3 & & 2 & \\
\hline
\end{tabular}




\section{Are you open most holidays?}

\begin{tabular}{|l|r|r|}
\hline Business Type & Yes & No \\
\hline Office & 4 & 31 \\
\hline Restaurant & 5 & 7 \\
\hline Retail & 11 & 20 \\
\hline
\end{tabular}

\begin{tabular}{|l|l|l|}
\hline Program Choice & Yes & No \\
\hline 2 Deg. Offset & 4 & 3 \\
\hline 4 Deg. Offset & 3 & 17 \\
\hline CPP & 13 & 38 \\
\hline
\end{tabular}

4. Is there a seasonal nature to your business?

\begin{tabular}{|l|r|r|r|r|}
\hline $\begin{array}{c}\text { Program } \\
\text { Choice }\end{array}$ & $\begin{array}{c}\text { Operations are pretty } \\
\text { consistent all year }\end{array}$ & $\begin{array}{c}\text { Busier in } \\
\text { Summer }\end{array}$ & $\begin{array}{c}\text { Busier in } \\
\text { Winter }\end{array}$ & $\begin{array}{c}\text { Busier on Certain } \\
\text { Holidays }\end{array}$ \\
\hline 2 Deg. Offset & 3 & 1 & 1 & 2 \\
\hline 4 Deg. Offset & 11 & 3 & 1 & 4 \\
\hline CPP & 38 & 7 & 4 & 2 \\
\hline
\end{tabular}

\begin{tabular}{|l|l|l|l|l|}
\hline $\begin{array}{l}\text { Business } \\
\text { Type }\end{array}$ & $\begin{array}{l}\text { Operations are pretty } \\
\text { consistent all year }\end{array}$ & $\begin{array}{l}\text { Busier in } \\
\text { Summer }\end{array}$ & $\begin{array}{l}\text { Busier in } \\
\text { Winter }\end{array}$ & $\begin{array}{l}\text { Busier on } \\
\text { Certain Holidays }\end{array}$ \\
\hline Office & 29 & 3 & 1 & 2 \\
\hline Restaurant & 6 & 5 & 1 & \\
\hline Retail & 17 & 3 & 4 & 6 \\
\hline
\end{tabular}

5. About what percent of the time are you present during work hours?

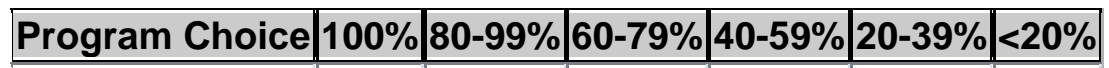

\begin{tabular}{|l|r|r|r|r|r|r|}
\hline 2 Deg. Offset & 1 & 3 & & 2 & & 1 \\
\hline 4 Deg. Offset & 3 & 12 & 3 & 2 & & \\
\hline CPP & 12 & 19 & 9 & 5 & 3 & 1 \\
\hline
\end{tabular}

\begin{tabular}{|l|l|l|l|l|l|l|}
\hline Business Type & $\mathbf{1 0 0} \%$ & $\mathbf{8 0 - 9 9 \%}$ & $\mathbf{6 0 - 7 9} \%$ & $\mathbf{4 0 - 5 9 \%}$ & $\mathbf{2 0 - 3 9 \%}$ & $<\mathbf{2 0 \%}$ \\
\hline Office & 5 & 17 & 7 & 4 & 1 & \\
\hline Restaurant & 3 & 4 & 1 & 2 & 1 & 1 \\
\hline Retail & 8 & 13 & 4 & 3 & 1 & 1 \\
\hline
\end{tabular}

\section{How many staff are present on a typical workday?}

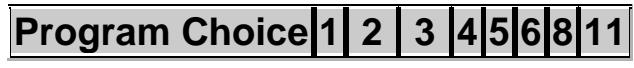




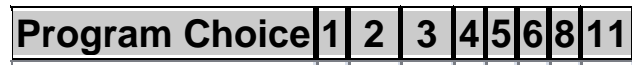

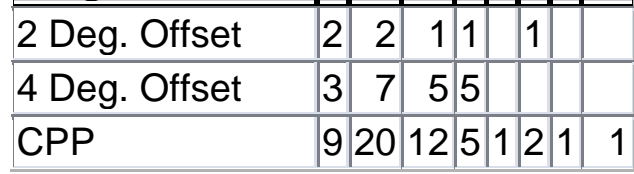

\begin{tabular}{|c|c|}
\hline \multicolumn{2}{|c|}{$|6| 8 \mid 1$} \\
\hline Office & \begin{tabular}{|l|l|l|l|l|l|}
6 & 10 & 10 & 5 & 2 & 1
\end{tabular} \\
\hline Restaurant & 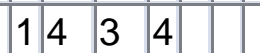 \\
\hline Retail & 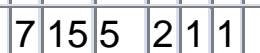 \\
\hline
\end{tabular}

Facility and Appliance Information

\section{Business space description}

\begin{tabular}{|l|r|r|r|r|}
\hline Program Choice & $\begin{array}{c}\text { Free standing } \\
\text { (detached) }\end{array}$ & $\begin{array}{c}\text { Building } \\
\text { attached on one } \\
\text { side }\end{array}$ & $\begin{array}{c}\text { Building attached } \\
\text { on both sides }\end{array}$ & $\begin{array}{c}\text { Unit in a } \\
\text { larger } \\
\text { building }\end{array}$ \\
\hline 2 Deg. Offset & 2 & 5 & \\
\hline 4 Deg. Offset & 2 & 11 & 7 & \\
\hline CPP & 13 & 16 & 20 & \\
\hline
\end{tabular}

\begin{tabular}{|l|l|l|l|l|}
\hline Business Type & $\begin{array}{c}\text { Free standing } \\
\text { (detached) }\end{array}$ & $\begin{array}{c}\text { Building } \\
\text { attached on one } \\
\text { side }\end{array}$ & $\begin{array}{c}\text { Building attached } \\
\text { on both sides }\end{array}$ & $\begin{array}{c}\text { Unit in a } \\
\text { larger } \\
\text { building }\end{array}$ \\
\hline Office & 10 & 14 & 9 & 1 \\
\hline Restaurant & 2 & 5 & 5 & \\
\hline Retail & 3 & 10 & 18 & \\
\hline
\end{tabular}

\section{How many floors does the building have?}

\begin{tabular}{|l|c|c|}
\hline Program Choice & $\mathbf{1}$ & $\mathbf{2}$ \\
\hline 2 Deg. Offset & 7 & \\
\hline 4 Deg. Offset & 15 & 5 \\
\hline CPP & 48 & 3 \\
\hline
\end{tabular}

\begin{tabular}{|l|l|l|}
\hline Business Type & 1 & 2 \\
\hline Office & 30 & 5 \\
\hline Restaurant & 12 & \\
\hline Retail & 28 & 3 \\
\hline
\end{tabular}


9. What floor does the business occupy?

\begin{tabular}{|l|c|c|}
\hline Program Choice & $\mathbf{1}$ & $\mathbf{2}$ \\
\hline 2 Deg. Offset & 7 & \\
\hline 4 Deg. Offset & 18 & 2 \\
\hline CPP & 51 & \\
\hline
\end{tabular}

\begin{tabular}{|l|l|l|}
\hline Business Type & $\mathbf{1}$ & $\mathbf{2}$ \\
\hline Office & 33 & 2 \\
\hline Restaurant & 12 & \\
\hline Retail & 31 & \\
\hline
\end{tabular}

10. Year the building was built?

\begin{tabular}{|l|l|l|l|l|l|l|l|l|l|l|}
\hline Program Choice & 0 & 1900 & 1920 & 1930 & 1950 & 1960 & 1970 & 1980 & 1990 & 2000 \\
\hline
\end{tabular}

\begin{tabular}{|c|c|c|c|c|c|c|c|c|c|c|}
\hline 2 Deg. Offset & 2 & & & & 1 & & 1 & 2 & & \\
\hline 4 Deg. Offset & 6 & & 1 & & 3 & 3 & 1 & 5 & 1 & \\
\hline CPP & 16 & 1 & & 1 & 5 & 5 & 7 & 7 & 2 & \\
\hline
\end{tabular}

\begin{tabular}{|l|l|l|l|l|l|l|l|l|l|l|l|}
\hline Business Type & $\mathbf{0}$ & $\mathbf{1 9 0 0}$ & $\mathbf{1 9 2 0}$ & $\mathbf{1 9 3 0}$ & $\mathbf{1 9 5 0}$ & $\mathbf{1 9 6 0}$ & $\mathbf{1 9 7 0}$ & $\mathbf{1 9 8 0}$ & $\mathbf{1 9 9 0}$ & $\mathbf{2 0 0 0}$ \\
\hline Office & 8 & & 1 & & 5 & 2 & 3 & 9 & 3 & 4 \\
\hline Restaurant & 6 & & & & 2 & 1 & 2 & 1 & & \\
\hline Retail & 10 & 1 & & 1 & 2 & 5 & 4 & 4 & & 1 \\
\hline
\end{tabular}


11. Size of the building, in square feet?

\begin{tabular}{|l|r|r|r|r|r|r|r|r|}
\hline Program Choice & 500 & 1000 & 1500 & 2000 & 2500 & 3000 & 3500 & 33000 \\
\hline 2 Deg. Offset & 2 & 2 & & 2 & 1 & & & \\
\hline 4 Deg. Offset & 7 & 6 & 3 & 2 & 2 & & & \\
\hline CPP & 10 & 18 & 9 & 5 & 1 & 5 & 1 & 1 \\
\hline
\end{tabular}

\begin{tabular}{|l|l|l|l|l|l|l|l|l|}
\hline Business Type & 500 & 1000 & 1500 & 2000 & 2500 & 3000 & 3500 & 33000 \\
\hline
\end{tabular}

\begin{tabular}{|l|l|l|l|l|l|l|l|l|}
\hline Office & 13 & 12 & 4 & & 1 & 3 & 1 & 1 \\
\hline Restaurant & 2 & 5 & 1 & 2 & 1 & 1 & & \\
\hline Retail & 4 & 9 & 7 & 7 & 2 & 1 & & \\
\hline
\end{tabular}

12. Window panes, single or double pane?

\begin{tabular}{|l|l|l|}
\hline Program Choice & Double pane & Single pane \\
\hline
\end{tabular}

\begin{tabular}{|l|r|r|}
\hline 2 Deg. Offset & & 7 \\
\hline 4 Deg. Offset & 5 & 15 \\
\hline CPP & 15 & 32 \\
\hline
\end{tabular}

\begin{tabular}{|l|l|l|}
\hline Business Type & Double pane & Single pane \\
\hline Office & 16 & 19 \\
\hline Restaurant & 1 & 11 \\
\hline Retail & 3 & 24 \\
\hline
\end{tabular}

\section{Percent of wall area that is windows on the west or southwest}

\begin{tabular}{|l|l|l|l|l|l|l|l|}
\hline Program Choice & $\mathbf{9 0 - 1 0 0 \%}$ & $\mathbf{7 0 - 8 9}$ & $\mathbf{5 0 - 6 9 \%}$ & $\mathbf{3 0 - 4 9 \%}$ & $\mathbf{1 0 - 2 9} \%$ & $\mathbf{1 - 1 0} \%$ & $\mathbf{0} \%$ \\
\hline 2 Deg. Offset & & 1 & 1 & & & 1 & 4 \\
\hline 4 Deg. Offset & & 4 & 2 & & 2 & 1 & 11 \\
\hline CPP & 2 & 3 & 4 & 3 & 4 & 10 & 25 \\
\hline
\end{tabular}

\begin{tabular}{|l|r|r|r|r|r|r|r|}
\hline Business Type & $90-100 \%$ & $\mathbf{7 0 - 8 9} \%$ & $50-69 \%$ & $30-49 \%$ & $\mathbf{1 0 - 2 9} \%$ & $1-10 \%$ & $0 \%$ \\
\hline Office & & 4 & 5 & 3 & 4 & 5 & 14 \\
\hline Restaurant & & 1 & 1 & & 1 & 3 & 6 \\
\hline Retail & 2 & 3 & 1 & & 1 & 4 & 20 \\
\hline
\end{tabular}

14. Percent of wall area that is windows on the east or southeast

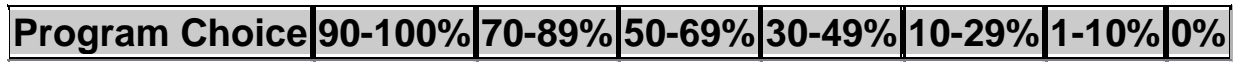
2 Deg. Offset 


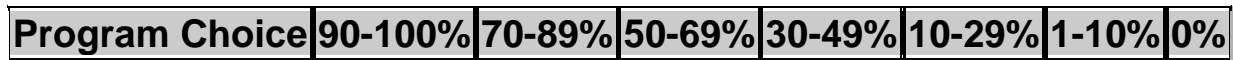

\begin{tabular}{|l|r|r|r|r|r|r|r|}
\hline 4 Deg. Offset & & 2 & 2 & 2 & 1 & 3 & 10 \\
\hline CPP & 2 & 2 & 5 & 4 & 4 & 10 & 23 \\
\hline
\end{tabular}

\begin{tabular}{|l|l|l|l|l|l|l|l|}
\hline Business Type & $\mathbf{9 0 - 1 0 0 \%}$ & $\mathbf{7 0 - 8 9 \%}$ & $\mathbf{5 0 - 6 9 \%}$ & $\mathbf{3 0 - 4 9}$ & $\mathbf{1 0 - 2 9} \%$ & $\mathbf{1 - 1 0 \%}$ & $\mathbf{0 \%}$ \\
\hline Office & & 3 & 4 & 4 & 3 & 7 & 13 \\
\hline Restaurant & 1 & 1 & & & 1 & 3 & 6 \\
\hline Retail & 1 & & 3 & 2 & 1 & 3 & 21 \\
\hline
\end{tabular}


15. Percent of wall area that is windows on the south

\begin{tabular}{|l|r|r|r|r|r|r|r|}
\hline Program Choice & $\mathbf{9 0 - 1 0 0 \%}$ & $\mathbf{7 0 - 8 9} \%$ & $\mathbf{5 0 - 6 9}$ & $\mathbf{3 0 - 4 9} \%$ & $\mathbf{1 0 - 2 9} \%$ & $\mathbf{1 - 1 0} \%$ & $\mathbf{0 \%}$ \\
\hline 2 Deg. Offset & 1 & 1 & & 1 & & & 4 \\
\hline 4 Deg. Offset & 2 & 1 & & 1 & 4 & 1 & 11 \\
\hline CPP & 2 & 4 & 2 & 9 & 3 & 5 & 24 \\
\hline
\end{tabular}

\begin{tabular}{|l|r|r|r|r|r|r|r|}
\hline Business Type & $\mathbf{9 0}-\mathbf{1 0 0} \%$ & $\mathbf{7 0 - 8 9} \%$ & $\mathbf{5 0 - 6 9 \%}$ & $\mathbf{3 0 - 4 9}$ & $\mathbf{1 0 - 2 9} \%$ & $\mathbf{1 - 1 0}$ & $\mathbf{0} \%$ \\
\hline Office & 1 & & 2 & 8 & 4 & 2 & 17 \\
\hline Restaurant & & 2 & & 1 & 1 & 3 & 5 \\
\hline Retail & 4 & 4 & & 2 & 2 & 1 & 17 \\
\hline
\end{tabular}

16. Percent of window area that is tinted or shaded

\begin{tabular}{|l|r|r|r|r|r|r|}
\hline Program Choice & $\mathbf{9 0 - 1 0 0 \%}$ & $\mathbf{7 0 - 8 9}$ & $\mathbf{5 0 - 6 9} \%$ & $\mathbf{3 0 - 4 9} \%$ & $\mathbf{1 0 - 2 9} \%$ & $<\mathbf{1 0} \%$ \\
\hline 2 Deg. Offset & 6 & 1 & & & & \\
\hline 4 Deg. Offset & 12 & 2 & 1 & 2 & 3 & \\
\hline CPP & 24 & 12 & 5 & & 3 & 3 \\
\hline
\end{tabular}

\begin{tabular}{|l|l|l|l|l|l|l|}
\hline Business Type & $\mathbf{9 0 - 1 0 0 \%}$ & $\mathbf{7 0 - 8 9} \%$ & $\mathbf{5 0 - 6 9 \%}$ & $\mathbf{3 0 - 4 9} \%$ & $\mathbf{1 0 - 2 9} \%$ & $<\mathbf{1 0} \%$ \\
\hline Office & 22 & 8 & 2 & 1 & & 1 \\
\hline Restaurant & 8 & 1 & 2 & & 1 & \\
\hline Retail & 12 & 6 & 2 & 1 & 5 & 2 \\
\hline
\end{tabular}




\section{Roof Insulation type}

\begin{tabular}{|l|l|l|l|l|}
\hline Program Choice & Batt & Blown in & Don't Know & Foam \\
\hline
\end{tabular}

\begin{tabular}{|l|r|r|r|r|}
\hline 2 Deg. Offset & 1 & & 4 & \\
\hline 4 Deg. Offset & 8 & 1 & 9 & \\
\hline CPP & 15 & 2 & 18 & 2 \\
\hline
\end{tabular}

\section{\begin{tabular}{|l|l|l|l|l|}
\hline Business Type & Batt & Blown in & Don't Know & Foam \\
\hline
\end{tabular}}

\begin{tabular}{|l|l|l|l|l|}
\hline Office & 11 & 3 & 16 & \\
\hline Restaurant & 3 & & 3 & 1 \\
\hline Retail & 10 & & 12 & 1 \\
\hline
\end{tabular}

18. Roof Insulation thickness (in inches)

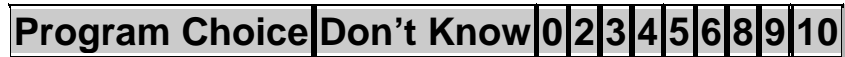

\begin{tabular}{|c|c|c|c|c|c|}
\hline 2 Deg. Offset & 6 & 1 & & & \\
\hline 4 Deg. Offset & 822 & 2 & 12 & & . \\
\hline CPP & \begin{tabular}{ll|l|l|l}
31 & 4
\end{tabular} & 11 & & \begin{tabular}{l|l|l}
8 & 1 & 1
\end{tabular} & T \\
\hline
\end{tabular}

\begin{tabular}{|c|c|c|c|c|c|}
\hline Business Type & Don't Know & 0.25 & & \begin{tabular}{|l|l|l|}
5 & 6 & 8 \\
\end{tabular} & \begin{tabular}{l|l}
9 & 10 \\
\end{tabular} \\
\hline Office & 22 & 2 & 1 & 81 & 1 \\
\hline Restaurant & 7 & $\begin{array}{ll}2 & 1\end{array}$ & 1 & 1 & \\
\hline Retail & 16 & 23 & 2 & 13 & 12 \\
\hline
\end{tabular}


19. Do you own or rent this property?

\begin{tabular}{|l|l|l|}
\hline Program Choice & Own & Rent \\
\hline
\end{tabular}

2 Deg. Offset

\begin{tabular}{|l|r|r|}
\hline 4 Deg. Offset & 3 & 17 \\
\hline
\end{tabular}

\begin{tabular}{|l|r|r|}
\hline CPP & 10 & 41 \\
\hline
\end{tabular}

\begin{tabular}{|l|l|l|}
\hline Business Type & Own & Rent \\
\hline
\end{tabular}

\begin{tabular}{|l|l|l|}
\hline Office & 13 & 22 \\
\hline Restaurant & & 12 \\
\hline Retail & & 31 \\
\hline
\end{tabular}

20. How many primary air conditioning units cool your space?

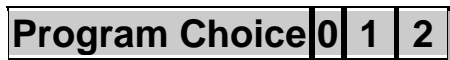

\begin{tabular}{|l|l|l|}
\hline 2 Deg. Offset & 5 & 2 \\
\hline
\end{tabular}

\begin{tabular}{|l||l|l|}
\hline 4 Deg. Offset & 17 & 3 \\
\hline
\end{tabular}

\begin{tabular}{l|l|l|l|}
\hline CPP & 3 & 38 & 10 \\
\hline
\end{tabular}

\begin{tabular}{|l|l|l|l|}
\hline Business Type & 0 & $\mathbf{1}$ & $\mathbf{2}$ \\
\hline Office & & 29 & 6 \\
\hline Restaurant & 1 & 8 & 3 \\
\hline Retail & 2 & 23 & 6 \\
\hline
\end{tabular}




\section{Tons of $A / C$ unit}

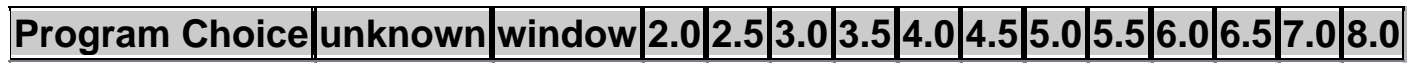

2 Deg. Offset

4 Deg. Offset

CPP

\begin{tabular}{r|r|}
2 & \\
3 & \\
12 &
\end{tabular}

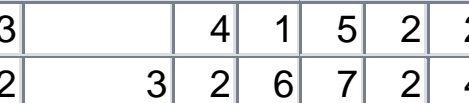

\begin{tabular}{|c|c|c|c|c|}
\hline & 1 & & & 1 \\
\hline 2 & 2 & & 1 & \\
\hline & 8 & 1 & 3 & 1 \\
\hline
\end{tabular}

\begin{tabular}{|l|l|l|l|l|l|l|l|l|l|l|l|l|l|l|}
\hline Business Type & unknown & window & 2.0 & 2.5 & 3.0 & 3.5 & 4.0 & 4.5 & 5.0 & 5.5 & 6.0 & 6.5 & 7.0 & 8.0 \\
\hline
\end{tabular}

\begin{tabular}{|c|c|c|c|c|c|c|c|c|c|c|c|c|c|}
\hline Office & 9 & & 1 & 7 & 8 & 2 & 3 & 1 & 2 & 1 & 1 & & \\
\hline Restaurant & 3 & 1 & & & & 1 & 1 & & 4 & & 1 & & 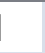 \\
\hline Retail & 4 & 2 & 5 & & 5 & 1 & 4 & & 5 & & 2 & 1 & \\
\hline
\end{tabular}

Values may include more than one unit. All businesses with values greater than 5 tons for $A / C$ have 2 units.

\section{Percent of area that is air conditioned}

\begin{tabular}{|l|r|r|r|r|r|r|}
\hline Program Choice & $\mathbf{9 0 - 1 0 0} \%$ & $\mathbf{7 0 - 8 9}$ & $\mathbf{5 0 - 6 9 \%}$ & $\mathbf{3 0 - 4 9 \%}$ & $\mathbf{1 0 - 2 9 \%}$ & $\mathbf{1 - 1 0} \%$ \\
\hline 2 Deg. Offset & 6 & 1 & & & & \\
\hline 4 Deg. Offset & 15 & 3 & & 1 & & \\
\hline CPP & 36 & 4 & 2 & 2 & 2 & 2 \\
\hline
\end{tabular}

\begin{tabular}{|l|l|l|l|l|l|l|}
\hline Business Type & $\mathbf{9 0 - 1 0 0} \%$ & $\mathbf{7 0 - 8 9} \%$ & $\mathbf{5 0 - 6 9 \%}$ & $\mathbf{3 0 - 4 9} \%$ & $\mathbf{1 0 - 2 9} \%$ & $\mathbf{1 - 1 0} \%$ \\
\hline Office & 29 & 3 & & & 1 & \\
\hline Restaurant & 8 & 2 & & 1 & & 1 \\
\hline Retail & 20 & 3 & 2 & 2 & 1 & 1 \\
\hline
\end{tabular}

\section{Approximate age of primary cooling system, in years}

\begin{tabular}{|c|c|c|c|c|c|c|c|c|c|c|c|c|c|c|}
\hline og & 2 & 5 & & & & & & & & & & & & \\
\hline 2 Deg. Offset & 1 & & & & 1 & & 1 & & & & & & & \\
\hline 4 Deg. Offset & 3 & & 3 & 2 & 1 & & 1 & 1 & 1 & & & & & \\
\hline CPP & $26 \mid 2$ & \begin{tabular}{|l|l|l}
4 & 1 & 1
\end{tabular} & 4 & 1 & 1 & 1 & 4 & & & & & & & \\
\hline
\end{tabular}

\begin{tabular}{|c|c|c|c|c|c|c|c|c|c|c|c|c|c|c|c|c|}
\hline Business 7 & 12 : & 56 & 31 & 1 & 1 & 13 & 1 & $15 \mid$ & 1 & $|7| 1$ & & & & & & \\
\hline Office & 2 & 1 & 1 & & 1 & 2 & & 3 & & 12 & & & 3 & 5 & & \\
\hline Restaurant & 1 & 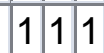 & & 2 & & 1 & 1 & & & & & & 1 & 1 & & \\
\hline Retail & 24 & 12 & tra & 4 & 2 & & & & 1 & & & 1 & 4 & 1 & & 1 \\
\hline
\end{tabular}


24. What fuel is used for water heating?

\begin{tabular}{|l|r|r|r|r|r|}
\hline Program Choice & Don't Have & Electric & Gas & Don't Pay & Don't Know \\
\hline 2 Deg. Offset & 1 & 2 & 3 & 1 & \\
\hline 4 Deg. Offset & 7 & 10 & 2 & 1 & \\
\hline CPP & 13 & 23 & 10 & 1 & 4 \\
\hline
\end{tabular}

\begin{tabular}{|l|l||l|l|l|l|}
\hline Business Type & Don't Have & Electric & Gas & Don't Pay & Don't Know \\
\hline
\end{tabular}

\begin{tabular}{|l|l|l|l|l|l|l|}
\hline Office & 12 & 14 & 5 & 1 & 3 \\
\hline Restaurant & & 6 & 6 & & \\
\hline Retail & 9 & 15 & 4 & 2 & 1 \\
\hline
\end{tabular}

25. What fuel is used for cooking?

\begin{tabular}{|l|l|l|l|}
\hline Program Choice & Don't Have & Electric & Gas \\
\hline
\end{tabular}

\begin{tabular}{|l|r|r|r|}
\hline 2 Deg. Offset & 4 & & 2 \\
\hline 4 Deg. Offset & 18 & 1 & 1 \\
\hline CPP & 40 & 7 & 3 \\
\hline
\end{tabular}

\begin{tabular}{|l|l||l|l|}
\hline Business Type & Don't Have & Electric & Gas \\
\hline Office & 30 & 5 & \\
\hline Restaurant & 4 & 2 & 6 \\
\hline Retail & 28 & 1 & \\
\hline
\end{tabular}

26. How many refrigeration units?

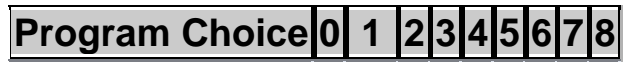

2 Deg. Offset

4 Deg. Offset

CPP

\begin{tabular}{l|l|l|l|l|l}
1 & 14 & 2 & 3
\end{tabular}

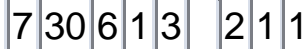

\begin{tabular}{|c|c|c|c|c|c|}
\hline Business 7 & $0 \mid 1$ & \begin{tabular}{|l|l|}
2 & 3 \\
\end{tabular} & & & \\
\hline Office & $5 \mid 23$ & \begin{tabular}{|l|l|}
5 & 1 \\
\end{tabular} & 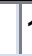 & & \\
\hline Restaurant & & \begin{tabular}{|l|l|}
2 & 2
\end{tabular} & & & \begin{tabular}{l|l}
1 & 1 \\
\end{tabular} \\
\hline Retail & 323 & \begin{tabular}{|l|l|}
3 & 2
\end{tabular} & & & \\
\hline
\end{tabular}

27. How many laundry units?

\begin{tabular}{|l|l|l|}
\hline Program Choice & $\mathbf{0}$ & $\mathbf{1}$ \\
\hline
\end{tabular}

\begin{tabular}{l|l|l}
\hline 2 Deg. Offset & 6 & 1
\end{tabular} 


\begin{tabular}{|l|l|l|}
\hline Program Choice & 0 & 1 \\
\hline 4 Deg. Offset & 19 & 1 \\
\hline CPP & 49 & 2 \\
\hline
\end{tabular}

\begin{tabular}{|l|l|l|}
\hline Business Type & $\mathbf{0}$ & $\mathbf{1}$ \\
\hline Office & 34 & 1 \\
\hline Restaurant & 12 & \\
\hline Retail & 28 & 3 \\
\hline
\end{tabular}

28. What is the primary type of interior lighting?

\begin{tabular}{|l|r|r|r|r|}
\hline Program Choice & Incandescent & Standard Fluorescent & Compact Fluorescent & Metal Halide \\
\hline 2 Deg. Offset & 1 & 6 & & \\
\hline 4 Deg. Offset & 1 & 17 & 2 & \\
\hline CPP & 3 & 45 & 2 & 1 \\
\hline
\end{tabular}

\begin{tabular}{|l|l|l|l|l|}
\hline Business Type & Incandescent & Standard Fluorescent & Compact Fluorescent & Metal Halide \\
\hline Office & 1 & 31 & 3 & \\
\hline Restaurant & 2 & 9 & 1 & \\
\hline Retail & 2 & 28 & & 1 \\
\hline
\end{tabular}

29. What is the approximate age of the primary lighting fixtures, in years?

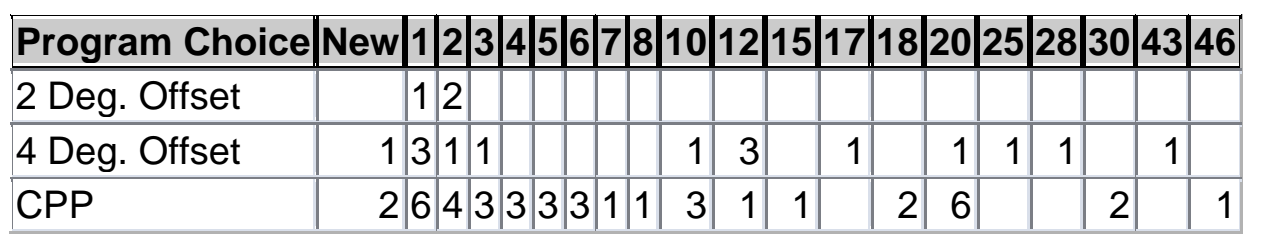

\begin{tabular}{|c|c|c|c|c|c|c|c|c|c|c|c|c|c|c|}
\hline usi & $\mathbf{N}$ & 112 & 16 & \begin{tabular}{|l|l|}
6 & 8 \\
\end{tabular} & 31 & & & & & & & & & \\
\hline Office & 1 & \begin{tabular}{|l|l|l|}
4 & 5 &
\end{tabular} & 1 & & 3 & 3 & 1 & 12 & $2<$ & & 1 & 1 & & \\
\hline Restaurant & 2 & 1 & \begin{tabular}{|l|l|}
1 & 1
\end{tabular} & & 1 & & & & T1 & & & & & 1 \\
\hline Retail & & 522 & 213 & \begin{tabular}{l|l|l}
3 & 1 & 1
\end{tabular} & & 1 & & & & 21 & & & 1 & \\
\hline
\end{tabular}

30. Approximately how many primary lighting fixtures in the area?

\begin{tabular}{|c|c|c|c|c|c|c|c|c|c|c|c|c|c|c|c|c|c|c|c|c|c|c|}
\hline Program Choic & $\begin{array}{lll}2 & 2 \\
\end{array}$ & $4 \sqrt[5]{6}$ & $6|7| 8 \mid 9$ & 9 & & & & & & & & & $\frac{7}{1}$ & & & & & & & & & \\
\hline 2 Deg. Offset & & 1 & 1 & & & te & 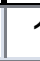 & & & & & & 1 & & & & & & & & & \\
\hline 4 Deg. Offset & 1 & 1 & $1|1|$ & t & 1 & 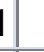 & & 1 & 2 & & & & 1 & 2 & & 1 & & 1 & & & & \\
\hline CPP & $1 \mid 1$ & $1 / 33$ & \begin{tabular}{l|l|l|l|}
3 & 1 & 3 & 5
\end{tabular} & & 4 & 4 & 6 & 3 & 1 & & 2 & 1 & & & 1 & & 1 & & 1 & 1 & 1 & 1 \\
\hline
\end{tabular}




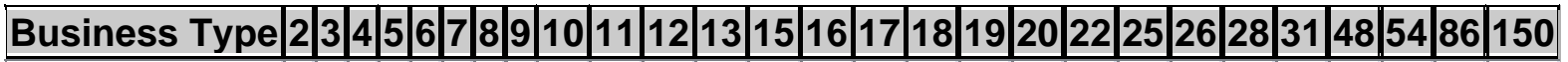

Office

Restaurant

Retail $\begin{array}{llllllllllll}1 & 2 & 1 & 3 & 3 & 4 & 3 & 2 & 3 & 2\end{array}$

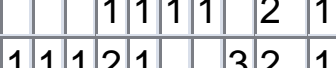

\begin{tabular}{lllllll|l|l|l|l|l}
1 & 4 & 2 & 1 & 3 & 1 & 1 & 1 & & 2
\end{tabular}

\begin{tabular}{l|l|l|}
1 & 1 & 1
\end{tabular}

1

2


31. What is the approximate wattage per fixture?

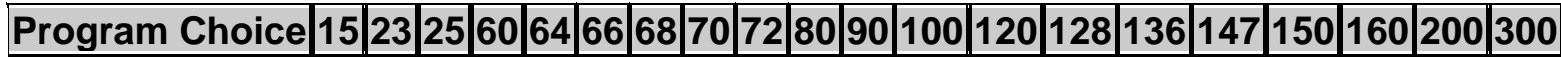

2 Deg. Offset

4 Deg. Offset

CPP

\begin{tabular}{l|l|l|l|l}
1 & 4 & 1
\end{tabular}

\begin{tabular}{l|l|l|l|l|l}
1 & & 1 & 1 & 15 & 1
\end{tabular}

$1 \quad$\begin{tabular}{lll|l|l|l} 
& 5 & 1 & 3
\end{tabular}

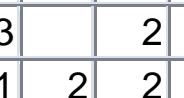

\begin{tabular}{|c|c|c|c|c|}
\hline & & & 1 & \\
\hline 1 & 1 & 1 & 5 & \\
\hline
\end{tabular}

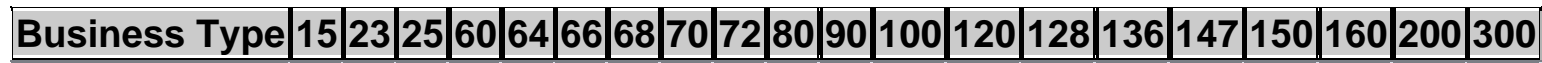

Office

Restaurant

Retail

1

\begin{tabular}{l|l|l|l}
1 & 6 \\
1 & 4 &
\end{tabular}

\begin{tabular}{l|l|l|l|l|}
\hline & 1 & 1 & 13 & 1
\end{tabular}

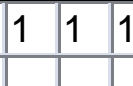

\begin{tabular}{|l|l|l|l|l|l|}
\hline 1 & 7 & 2 & 3 & 1 & 1 \\
\hline & 2 & & & & 1 \\
\hline & 2 & & 1 & 1 & 2 \\
\hline
\end{tabular}

\begin{tabular}{l|l|l|l|l|l|l|}
\hline 1 & & 1 & 3 & & \\
\hline & & 1 & & & & \\
\hline
\end{tabular}

\section{Occupant Behavior and Comfort}

32. Do you use a programmable thermostat to automatically adjust temperature settings?

\begin{tabular}{|l|l|l|l|}
\hline Program Choice & No & Use it manually & Yes \\
\hline
\end{tabular}

\begin{tabular}{|l|r|r|r|}
\hline 2 Deg. Offset & 3 & 2 & 2 \\
\hline 4 Deg. Offset & 6 & 7 & 7 \\
\hline CPP & 21 & 16 & 14 \\
\hline
\end{tabular}

\begin{tabular}{|l|l|l|l|}
\hline Business Type & No & Use it manually & Yes \\
\hline Office & 10 & 13 & 12 \\
\hline Restaurant & 5 & 3 & 4 \\
\hline Retail & 15 & 9 & 7 \\
\hline
\end{tabular}

33. What is the summer temperature setting of your primary cooling system when the building is occupied?

\begin{tabular}{|l|l|l|l|l|l|l|l|l|l|l|l|l|l|l|l|l|l|}
\hline Program Choice & 60 & 68 & 69 & 70 & 71 & 72 & 73 & 74 & 75 & 76 & 77 & 78 & 80 & 82 & As low as it goes & High & On \\
\hline
\end{tabular}

2 Deg. Offset

4 Deg. Offset

CPP

\begin{tabular}{r|r|r|r|r|r|r|r|} 
& & 1 & 3 & & 1 & & 2 \\
\hline & 2 & & 2 & & 2 & & 2 \\
\hline 1 & 2 & & 4 & 1 & 13 & 2 & 6 \\
\hline
\end{tabular}

\begin{tabular}{l|l|l|}
2 & 2 & 2 \\
\hline 6 & 3 & 2
\end{tabular}

\begin{tabular}{l|l}
2 & 2 \\
\hline 2 & 4
\end{tabular}

\begin{tabular}{|l|l|}
\hline 4 & 1 \\
\hline 4 & 1
\end{tabular}

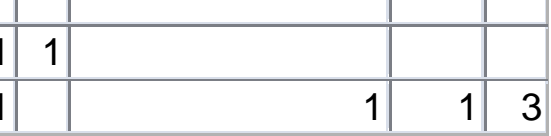

\begin{tabular}{|l|l|l|l|l|l|l|l|l|l|l|l|l|l|l|l|l|l|l|}
\hline Business Type & 60 & 68 & 69 & 70 & 71 & 72 & 73 & 74 & 75 & 76 & 77 & 78 & 80 & 82 & As low as it goes & High & On \\
\hline Office & & 2 & & 1 & 1 & 8 & 2 & 7 & 2 & 2 & 5 & 3 & 1 & & 1 & & & \\
\hline Restaurant & & 1 & 1 & 5 & & 1 & & 1 & & & & 1 & & & & & 1 & \\
\hline Retail & 1 & 1 & & 3 & & 7 & & 2 & 3 & 2 & 1 & 4 & 1 & 1 & & & & 3 \\
\hline
\end{tabular}


34. What is the summer temperature setting of your primary cooling system when the building is unoccupied?

\begin{tabular}{|l|r|r|r|r|r|r|r|r|r|}
\hline Program Choice & $\mathbf{7 0}$ & $\mathbf{7 5}$ & $\mathbf{7 8}$ & $\mathbf{8 0}$ & $\mathbf{8 2}$ & $\mathbf{8 4}$ & $\mathbf{8 5}$ & $\mathbf{9 0}$ & Off \\
\hline 2 Deg. Offset & & & & & & 1 & 1 & 1 & 4 \\
\hline 4 Deg. Offset & & 2 & 3 & 1 & & & & & 13 \\
\hline CPP & 1 & & 2 & 3 & 2 & 1 & 4 & 3 & 32 \\
\hline
\end{tabular}

\begin{tabular}{|l|l|l|l|l|l|l|l|l|l|}
\hline Business Type & $\mathbf{7 0}$ & $\mathbf{7 5}$ & $\mathbf{7 8}$ & $\mathbf{8 0}$ & $\mathbf{8 2}$ & $\mathbf{8 4}$ & $\mathbf{8 5}$ & $\mathbf{9 0}$ & $\mathbf{O f f}$ \\
\hline Office & & 1 & 3 & 2 & 1 & 2 & 1 & 2 & 22 \\
\hline Restaurant & & & 1 & 1 & & & 1 & & 8 \\
\hline Retail & 1 & 1 & 1 & 1 & 1 & & 3 & 2 & 19 \\
\hline
\end{tabular}

35. Can or does staff (anyone else) adjust the thermostat settings?

\begin{tabular}{|l|r|r|r|r|}
\hline Program Choice & No & They're not supposed to & We mostly do it_ & Yes \\
\hline 2 Deg. Offset & 4 & 1 & & 2 \\
\hline 4 Deg. Offset & 5 & & 1 & 14 \\
\hline CPP & 6 & & 41 \\
\hline
\end{tabular}

\begin{tabular}{|l|l|l|l|l|}
\hline Business Type & No & They're not supposed to & We mostly do it_les & Yes \\
\hline Office & 4 & & & 31 \\
\hline Restaurant & 5 & 1 & 1 & 4 \\
\hline Retail & 6 & & & 22 \\
\hline
\end{tabular}

36. Would you prefer they could not or did not adjust the thermostat?

\begin{tabular}{|l|r|r|r|}
\hline Program Choice & Yes & No & Don't know \\
\hline 2 Deg. Offset & 2 & 5 & \\
\hline 4 Deg. Offset & 4 & 14 & 2 \\
\hline CPP & 14 & 32 & 1 \\
\hline
\end{tabular}

\begin{tabular}{|l|l|l|l|}
\hline Business Type & Yes & No & Don't know \\
\hline Office & 8 & 26 & 1 \\
\hline Restaurant & 7 & 3 & 1 \\
\hline Retail & 5 & 22 & 1 \\
\hline
\end{tabular}


37. Does sun through your windows cause visual or thermal discomfort?

\begin{tabular}{|l|r|r|r|}
\hline Program Choice & Yes & No & Don't know \\
\hline 2 Deg. Offset & 3 & 4 & \\
\hline 4 Deg. Offset & 7 & 12 & 1 \\
\hline CPP & 19 & 30 & \\
\hline
\end{tabular}

\begin{tabular}{|l|l|l|l|}
\hline Business Type & Yes & No & Don't know \\
\hline Office & 15 & 19 & 1 \\
\hline Restaurant & 4 & 8 & \\
\hline Retail & 10 & 19 & \\
\hline
\end{tabular}

38. Is some or all of your space uncomfortably warm during the summer months?

\begin{tabular}{|l|r|r|r|}
\hline Program Choice & Yes & No & Don't know \\
\hline 2 Deg. Offset & 5 & 1 & 1 \\
\hline 4 Deg. Offset & 9 & 9 & 2 \\
\hline CPP & 23 & 26 & 2 \\
\hline
\end{tabular}

\begin{tabular}{|l|l|l|l|}
\hline Business Type & Yes & No & Don't know \\
\hline Office & 17 & 17 & 1 \\
\hline Restaurant & 6 & 5 & 1 \\
\hline Retail & 14 & 14 & 3 \\
\hline
\end{tabular}

39. Is some or all of your space uncomfortably warm during the winter months?

\begin{tabular}{|l|r|r|r|}
\hline Program Choice & Yes & No & Don't know \\
\hline 2 Deg. Offset & 1 & 6 & \\
\hline 4 Deg. Offset & 1 & 16 & 3 \\
\hline CPP & 7 & 42 & 2 \\
\hline
\end{tabular}

\begin{tabular}{|l|l|l|l|}
\hline Business Type & Yes & No & Don't know \\
\hline Office & 4 & 29 & 2 \\
\hline Restaurant & 2 & 10 & \\
\hline Retail & 3 & 25 & 3 \\
\hline
\end{tabular}


40. Is your door open during business hours?

\begin{tabular}{|l|r|r|r|}
\hline Program Choice & Yes & No & Don't know \\
\hline 2 Deg. Offset & & 7 & \\
\hline 4 Deg. Offset & 1 & 17 & 2 \\
\hline CPP & 14 & 34 & 1 \\
\hline
\end{tabular}

\begin{tabular}{|l|l|l|l|}
\hline Business Type & Yes & No & Don't know \\
\hline
\end{tabular}

\begin{tabular}{|l|l|l|l|}
\hline Office & 6 & 27 & 1 \\
\hline Restaurant & 2 & 9 & \\
\hline Retail & 7 & 22 & 2 \\
\hline
\end{tabular}

41. Are staff members allowed to wear clothing that is appropriate for the weather? \begin{tabular}{|l|l|l|l|}
\hline Program Choice & Yes & No & Don't know \\
\hline
\end{tabular}

\begin{tabular}{|l|r|r|r|}
\hline 2 Deg. Offset & 5 & 2 & \\
\hline 4 Deg. Offset & 19 & 1 & \\
\hline CPP & 46 & 3 & 1 \\
\hline
\end{tabular}

\begin{tabular}{|l|l|l|l|}
\hline Business Type & Yes & No & Don't know \\
\hline Office & 33 & & 1 \\
\hline Restaurant & 8 & 4 & \\
\hline Retail & 29 & 2 & \\
\hline
\end{tabular}

\section{Peak Reduction Strategies}

42. Is this business open during SMUD's peak time?

\begin{tabular}{|l|r|r|}
\hline Program Choice & Yes & No \\
\hline 2 Deg. Offset & 7 & \\
\hline 4 Deg. Offset & 18 & 2 \\
\hline CPP & 44 & 7 \\
\hline
\end{tabular}

\begin{tabular}{|l|l|l|}
\hline Business Type & Yes & No \\
\hline Office & 30 & 5 \\
\hline Restaurant & 11 & 1 \\
\hline Retail & 28 & 3 \\
\hline
\end{tabular}


43. Do you precool before peak times (4-7pm) with air 44. conditioning?

\begin{tabular}{|l|r|r|r|}
\hline Program Choice & Every Day & Sometimes & Never \\
\hline 2 Deg. Offset & 1 & & 6 \\
\hline 4 Deg. Offset & 1 & 4 & 14 \\
\hline CPP & 6 & 13 & 25 \\
\hline
\end{tabular}

\begin{tabular}{|l|l|l|l|}
\hline Business Type & Every Day & Sometimes & Never \\
\hline
\end{tabular}

\begin{tabular}{|l|l|l|l|}
\hline Office & 4 & 8 & 21 \\
\hline Restaurant & 3 & 2 & 5 \\
\hline Retail & 1 & 7 & 19 \\
\hline
\end{tabular}

44. Would you precool before peak times (4-7pm) with air conditioning?

\begin{tabular}{|l|l|l|l|l|}
\hline Program Choice & During Events Only|Every Day & Sometimes & Never \\
\hline
\end{tabular}

\begin{tabular}{|c|c|c|c|c|c|}
\hline 2 Deg. Offset & & 3 & 1 & & 3 \\
\hline 4 Deg. Offset & & 2 & 2 & 1 & 14 \\
\hline CPP & 1 & 9 & 6 & 14 & 16 \\
\hline
\end{tabular}

\begin{tabular}{|l|l|l|l|l|l|}
\hline Business Type & 0 & During Events Only & Every Day & Sometimes & Never \\
\hline Office & 1 & 4 & 4 & 5 & 18 \\
\hline Restaurant & 4 & 3 & 2 & 3 \\
\hline Retail & 6 & 2 & 8 & 12 \\
\hline
\end{tabular}

$0=$ No answer to this question.

45. Do you precool before peak times (4-7pm) by running the building ventilation system at night?

\begin{tabular}{|l|r|r|r|}
\hline Program Choice & Every Day & Sometimes & Never \\
\hline 2 Deg. Offset & 1 & & 6 \\
\hline 4 Deg. Offset & & & 19 \\
\hline CPP & 1 & 2 & 41 \\
\hline
\end{tabular}

\begin{tabular}{|l|l|l|l|}
\hline Business Type & Every Day & Sometimes & Never \\
\hline Office & & & 33 \\
\hline Restaurant & 1 & 1 & 8 \\
\hline Retail & 1 & 1 & 25 \\
\hline
\end{tabular}


46. Would you precool before peak times (4-7pm) by running the building ventilation system at night?

\begin{tabular}{|l|r|r|r||r|}
\hline Program Choice & During Events Only & Every Day & Sometimes & Never \\
\hline 2 Deg. Offset & 1 & 2 & 4 \\
\hline 4 Deg. Offset & 1 & 1 & & 18 \\
\hline CPP & 2 & 7 & 37 \\
\hline
\end{tabular}

\begin{tabular}{|l|l|l|l|l|}
\hline Business Type & During Events Only & Every Day & Sometimes & Never \\
\hline Office & 1 & 1 & 4 & 27 \\
\hline Restaurant & & 2 & 1 & 9 \\
\hline Retail & & 1 & 4 & 23 \\
\hline
\end{tabular}

47. Do you precool before peak times (4-7pm) by opening doors or windows?

\begin{tabular}{|l|r|r|r|}
\hline Program Choice & Every Day & Sometimes & Never \\
\hline 2 Deg. Offset & 2 & & 5 \\
\hline 4 Deg. Offset & 3 & 9 & 7 \\
\hline CPP & 16 & 12 & 16 \\
\hline
\end{tabular}

\begin{tabular}{|l|l|l|l|}
\hline Business Type & Every Day & Sometimes & Never \\
\hline Office & 8 & 12 & 13 \\
\hline Restaurant & 4 & 1 & 5 \\
\hline Retail & 9 & 8 & 10 \\
\hline
\end{tabular}

48. Would you precool before peak times (4-7pm) by opening doors or windows?

\begin{tabular}{|l|r|r|r|}
\hline Program Choice & Every Day & Sometimes & Never \\
\hline 2 Deg. Offset & 2 & 1 & 4 \\
\hline 4 Deg. Offset & 4 & 8 & 6 \\
\hline CPP & 16 & 14 & 17 \\
\hline
\end{tabular}

\begin{tabular}{|l|l|l|l|}
\hline Business Type & Every Day & Sometimes & Never \\
\hline Office & 9 & 13 & 11 \\
\hline Restaurant & 4 & 1 & 7 \\
\hline Retail & 9 & 9 & 9 \\
\hline
\end{tabular}

49. Do you lower $A / C$ use by turning on a floor or desk fan?

\begin{tabular}{|l|l|l|l|}
\hline Program Choice & Every Day & Sometimes & Never \\
\hline
\end{tabular}

2 Deg. Offset

1

$3 \quad 3$


Program Choice Every Day Sometimes Never

\begin{tabular}{|l|r|r|r|}
\hline 4 Deg. Offset & 3 & 5 & 10 \\
\hline CPP & 16 & 9 & 19 \\
\hline
\end{tabular}

\begin{tabular}{|l|l|}
\hline Business Type & Every Day|Sometimes \\
\hline
\end{tabular}

\begin{tabular}{|l|l|l|l|}
\hline Office & 11 & 8 & 14 \\
\hline Restaurant & 2 & 5 & 3 \\
\hline Retail & 7 & 4 & 15 \\
\hline
\end{tabular}

50. Would you lower $A / C$ use by turning on a floor or desk fan?

\begin{tabular}{|l|r|r|r|r|}
\hline Program Choice & During Events Only & Every Day & Sometimes & Never \\
\hline 2 Deg. Offset & 1 & 1 & 4 & 1 \\
\hline 4 Deg. Offset & 1 & 3 & 7 & 7 \\
\hline CPP & & 18 & 10 & 19 \\
\hline
\end{tabular}

\begin{tabular}{|l|l|l|l|l|}
\hline Business Type & During Events Only & Every Day & Sometimes & Never \\
\hline Office & & 11 & 11 & 11 \\
\hline Restaurant & 1 & 3 & 5 & 3 \\
\hline Retail & 1 & 8 & 5 & 13 \\
\hline
\end{tabular}

51. Do you close the shades or blinds at the windows?

Program Choice Every Day Sometimes Never

\begin{tabular}{|l|r|r|r|}
\hline 2 Deg. Offset & 1 & & 6 \\
\hline 4 Deg. Offset & 6 & 4 & 9 \\
\hline CPP & 16 & 3 & 25 \\
\hline
\end{tabular}

\begin{tabular}{|l|l|l|l|}
\hline Business Type & Every Day & Sometimes & Never \\
\hline Office & 18 & 6 & 9 \\
\hline Restaurant & 1 & & 9 \\
\hline Retail & 4 & 1 & 22 \\
\hline
\end{tabular}

52. Would you close the shades or blinds at the windows?

\begin{tabular}{|l|r|r|r|r|}
\hline Program Choice & During Events Only & Every Day & Sometimes & Never \\
\hline 2 Deg. Offset & 1 & 1 & & 5 \\
\hline 4 Deg. Offset & 1 & 7 & 4 & 7 \\
\hline CPP & 1 & 19 & 3 & 24 \\
\hline
\end{tabular}




\begin{tabular}{|l|l|l|l|l|}
\hline Business Type & During Events Only & Every Day & Sometimes & Never \\
\hline Office & 3 & 20 & 6 & 4 \\
\hline Restaurant & & 2 & & 10 \\
\hline Retail & & 5 & 1 & 22 \\
\hline
\end{tabular}

53. Do you put up an awning or umbrella to shade the windows?

\begin{tabular}{|l|r|r|}
\hline Program Choice & Every Day & Never \\
\hline 2 Deg. Offset & 4 & 3 \\
\hline 4 Deg. Offset & 2 & 17 \\
\hline CPP & 9 & 35 \\
\hline
\end{tabular}

\begin{tabular}{|l|l|l|}
\hline Business Type & Every Day & Never \\
\hline Office & 3 & 30 \\
\hline Restaurant & 5 & 5 \\
\hline Retail & 7 & 20 \\
\hline
\end{tabular}

54. Would you put up an awning or umbrella to shade the windows?

\begin{tabular}{|l|r|r|r|}
\hline Program Choice & Every Day & Sometimes & Never \\
\hline 2 Deg. Offset & 4 & 3 \\
\hline 4 Deg. Offset & 2 & & 17 \\
\hline CPP & 9 & 1 & 34 \\
\hline
\end{tabular}

\begin{tabular}{|l|l|l|l|}
\hline Business Type & Every Day & Sometimes & Never \\
\hline Office & 4 & 1 & 28 \\
\hline Restaurant & 4 & & 6 \\
\hline Retail & 7 & & 20 \\
\hline
\end{tabular}

55. Do you turn off some electric lights?

\begin{tabular}{|l|r|r|r|}
\hline Program Choice & Every Day & Sometimes & Never \\
\hline 2 Deg. Offset & 4 & 1 & 2 \\
\hline 4 Deg. Offset & 6 & 6 & 7 \\
\hline CPP & 15 & 16 & 13 \\
\hline
\end{tabular}

\begin{tabular}{|l|l|l|l|}
\hline Business Type & Every Day & Sometimes & Never \\
\hline Office & 13 & 14 & 6 \\
\hline Restaurant & 2 & 2 & 6 \\
\hline Retail & 10 & 7 & 10 \\
\hline
\end{tabular}


56. Would you turn off some electric lights?

\begin{tabular}{|l|r|r|r|r|}
\hline Program Choice & During Events Only & Every Day & Sometimes & Never \\
\hline 2 Deg. Offset & & 3 & 2 & 2 \\
\hline 4 Deg. Offset & 3 & 5 & 5 & 6 \\
\hline CPP & 3 & 19 & 17 & 7 \\
\hline
\end{tabular}

\begin{tabular}{|l|l|l|l|l|}
\hline Business Type & During Events Only & Every Day & Sometimes & Never \\
\hline Office & 2 & 17 & 12 & 2 \\
\hline Restaurant & 1 & 4 & 2 & 5 \\
\hline Retail & & 9 & 10 & 8 \\
\hline
\end{tabular}

57. Do you turn off all the electric lights?

\begin{tabular}{|l|l|l|l|}
\hline Program Choice & Every Day & Sometimes & Never \\
\hline
\end{tabular}

\begin{tabular}{|c|c|c|c|}
\hline 2 Deg. Offset & & 1 & 6 \\
\hline 4 Deg. Offset & & 1 & 18 \\
\hline CPP & 2 & 1 & 41 \\
\hline
\end{tabular}

\begin{tabular}{|l|l|l|l|}
\hline Business Type & Every Day & Sometimes & Never \\
\hline Office & & 3 & 30 \\
\hline Restaurant & 1 & 9 \\
\hline Retail & 1 & & 9 \\
\hline
\end{tabular}

58. Would you turn off all the electric lights?

\begin{tabular}{|l|r|r|r|r|}
\hline Program Choice & During Events Only & Every Day & Sometimes & Never \\
\hline 2 Deg. Offset & & & 1 & 6 \\
\hline 4 Deg. Offset & 1 & & 1 & 18 \\
\hline CPP & 3 & 2 & 40 \\
\hline
\end{tabular}

\begin{tabular}{|l|l|}
\hline Business Type During Events Only|Every Day|Sometimes|Never \\
\hline
\end{tabular}

\begin{tabular}{|l|l|l|l|l|}
\hline Office & 1 & & 3 & 29 \\
\hline Restaurant & & 2 & & 10 \\
\hline Retail & & 1 & 1 & 25 \\
\hline
\end{tabular}

59. Do you turn off some electrical equipment?

\begin{tabular}{|l|l|l|}
\hline Program Choice & Every Day Sometimes & Never \\
\hline
\end{tabular} 
\begin{tabular}{|l|l|l|l|}
\hline Program Choice & Every Day & Sometimes & Never \\
\hline
\end{tabular}

\begin{tabular}{|l|r|r|r|}
\hline 2 Deg. Offset & 1 & & 6 \\
\hline 4 Deg. Offset & & 4 & 15 \\
\hline CPP & 2 & 11 & 31 \\
\hline
\end{tabular}

\begin{tabular}{|l|l|l|l|}
\hline Business Type & Every Day & Sometimes & Never \\
\hline
\end{tabular}

\begin{tabular}{|l|l|l|l|}
\hline Office & & 11 & 22 \\
\hline Restaurant & 1 & & 9 \\
\hline Retail & 2 & 4 & 21 \\
\hline
\end{tabular}

60. Would you turn off some electrical equipment?

\begin{tabular}{|l|r|r|r|r|}
\hline Program Choice & During Events Only & Every Day & Sometimes & Never \\
\hline 2 Deg. Offset & 1 & 2 & 4 \\
\hline 4 Deg. Offset & 4 & & 5 & 14 \\
\hline CPP & 4 & 12 & 28 \\
\hline
\end{tabular}

\begin{tabular}{|l|r|r|r|r|}
\hline Business Type & During Events Only & Every Day & Sometimes & Never \\
\hline Office & 2 & & 13 & 18 \\
\hline Restaurant & 2 & 1 & 2 & 7 \\
\hline Retail & & 3 & 4 & 21 \\
\hline
\end{tabular}

\section{Do you turn off all electrical equipment?}

\begin{tabular}{|l|l|l|}
\hline Program Choice & Sometimes & Never \\
\hline
\end{tabular}

\begin{tabular}{|l|r|r|}
\hline 2 Deg. Offset & 7 \\
\hline 4 Deg. Offset & & 19 \\
\hline CPP & 3 & 41 \\
\hline
\end{tabular}

\begin{tabular}{|l|l|l|}
\hline Business Type & Sometimes & Never \\
\hline Office & & 33 \\
\hline Restaurant & & 10 \\
\hline Retail & 3 & 24 \\
\hline
\end{tabular}

62. Would you turn off all electrical equipment?

\begin{tabular}{|l|l|l|}
\hline Program Choice & Sometimes & Never \\
\hline
\end{tabular}

\begin{tabular}{|l|r|r|}
\hline 2 Deg. Offset & 7 \\
\hline 4 Deg. Offset & 1 & 18 \\
\hline
\end{tabular}


\begin{tabular}{|l|l|}
\hline Program Choice Sometimes Never \\
\hline
\end{tabular}

\begin{tabular}{|l|r|r|}
\hline CPP & 4 & 43 \\
\hline
\end{tabular}

\begin{tabular}{|l|l|l|}
\hline Business Type & Sometimes & Never \\
\hline Office & 2 & 31 \\
\hline Restaurant & & 12 \\
\hline Retail & 3 & 25 \\
\hline
\end{tabular}

63. Do you let the staff dress more casually?

\begin{tabular}{|l|r|r|r|}
\hline Program Choice & Every Day & Sometimes & Never \\
\hline 2 Deg. Offset & 4 & 1 & 2 \\
\hline 4 Deg. Offset & 17 & 1 & 1 \\
\hline CPP & 33 & 7 & 4 \\
\hline
\end{tabular}

\begin{tabular}{|l|l|l|l|}
\hline Business Type & Every Day & Sometimes & Never \\
\hline Office & 24 & 6 & 3 \\
\hline Restaurant & 6 & 1 & 3 \\
\hline Retail & 24 & 2 & 1 \\
\hline
\end{tabular}

64. Would you let the staff dress more casually?

Program Choice Every Day Sometimes Never

\begin{tabular}{|l|r|r|r|}
\hline 2 Deg. Offset & 4 & 1 & 2 \\
\hline 4 Deg. Offset & 17 & 1 & 1 \\
\hline CPP & 35 & 7 & 5 \\
\hline
\end{tabular}

\begin{tabular}{|l|l|l|l|}
\hline Business Type & Every Day & Sometimes & Never \\
\hline Office & 24 & 6 & 3 \\
\hline Restaurant & 8 & & 4 \\
\hline Retail & 24 & 3 & 1 \\
\hline
\end{tabular}

65. Do you let some staff go home early?

\begin{tabular}{|l|r|r|r|}
\hline Program Choice & Every Day & Sometimes & Never \\
\hline 2 Deg. Offset & 1 & 4 & 2 \\
\hline 4 Deg. Offset & & 10 & 9 \\
\hline CPP & 3 & 22 & 19 \\
\hline
\end{tabular}

\begin{tabular}{|l|l|}
\hline Business Type & Every Day|Sometimes Never \\
\hline
\end{tabular} 


\begin{tabular}{|l|l|l|l|}
\hline Business Type & Every Day & Sometimes & Never \\
\hline Office & 4 & 18 & 11 \\
\hline Restaurant & & 6 & 4 \\
\hline Retail & 12 & 15 \\
\hline
\end{tabular}

66. Would you let some staff go home early?

\begin{tabular}{|l|r|r|r||r|}
\hline Program Choice & During Events Only & Every Day & Sometimes & Never \\
\hline 2 Deg. Offset & & 1 & 4 & 2 \\
\hline 4 Deg. Offset & 4 & & 11 & 8 \\
\hline CPP & 4 & 4 & 19 & 20 \\
\hline
\end{tabular}

\begin{tabular}{|l|l|l|l|l|}
\hline Business Type & During Events Only & Every Day & Sometimes & Never \\
\hline Office & 3 & 4 & 17 & 9 \\
\hline Restaurant & & & 6 & 6 \\
\hline Retail & 1 & 1 & 11 & 15 \\
\hline
\end{tabular}

67. Do you close the door during peak hours?

\begin{tabular}{|l|r|r|r|r|}
\hline Program Choice & During Events Only & Every Day & Sometimes & Never \\
\hline 2 Deg. Offset & 6 & & 1 \\
\hline 4 Deg. Offset & 1 & 18 & & 1 \\
\hline CPP & 1 & 37 & 4 & 2 \\
\hline
\end{tabular}

\begin{tabular}{|l|l|l|l|l|}
\hline Business Type & During Events Only & Every Day & Sometimes & Never \\
\hline
\end{tabular}

\begin{tabular}{|l|l|l|l|l|}
\hline Office & 30 & 2 & 1 \\
\hline Restaurant & & 9 & 1 & \\
\hline Retail & 1 & 22 & 1 & 3 \\
\hline
\end{tabular}

68. Would you close the door during peak hours?

\begin{tabular}{|l|l|l|l|}
\hline Program Choice & Every Day & Sometimes & Never \\
\hline
\end{tabular}

\begin{tabular}{|l|r|r|r|}
\hline 2 Deg. Offset & 6 & 1 \\
\hline 4 Deg. Offset & 18 & & 1 \\
\hline CPP & 42 & 3 & 2 \\
\hline
\end{tabular}

\begin{tabular}{|l|l|l|l|}
\hline Business Type & Every Day & Sometimes & Never \\
\hline Office & 31 & 1 & 1 \\
\hline Restaurant & 11 & 1 & \\
\hline Retail & 24 & 1 & 3 \\
\hline
\end{tabular}


69. Do you close the business during peak hours?

\begin{tabular}{|l|r|r|r|}
\hline Program Choice & Every Day & Sometimes & Never \\
\hline 2 Deg. Offset & 1 & 1 & 5 \\
\hline 4 Deg. Offset & 1 & 5 & 13 \\
\hline CPP & 6 & 7 & 32 \\
\hline
\end{tabular}

\begin{tabular}{|l|l|l|l|}
\hline Business Type & Every Day & Sometimes & Never \\
\hline Office & 4 & 9 & 20 \\
\hline Restaurant & 1 & 1 & 8 \\
\hline Retail & 3 & 3 & 22 \\
\hline
\end{tabular}

70. Would you close the business during peak hours?

\begin{tabular}{|l|l||l||l|}
\hline Program Choice & During Events Only & Every Day & Sometimes \\
\hline
\end{tabular}

\begin{tabular}{|l|r|r|r|r|}
\hline 2 Deg. Offset & 1 & 1 & 5 \\
\hline 4 Deg. Offset & 6 & 1 & 5 & 13 \\
\hline CPP & 7 & 7 & 28 \\
\hline
\end{tabular}

\begin{tabular}{|l|l|l|l|l|}
\hline Business Type & During Events Only & Every Day & Sometimes & Never \\
\hline Office & 3 & 4 & 10 & 16 \\
\hline Restaurant & & 1 & 1 & 10 \\
\hline Retail & 3 & 4 & 2 & 20 \\
\hline
\end{tabular}




\section{Summer (Post-Event) Surveys}

1. Were you aware of the event?

\begin{tabular}{|l|r|r|r|r|r|}
\hline $\begin{array}{c}\text { Program } \\
\text { Choice }\end{array}$ & $\begin{array}{c}\text { No } \\
\text { answer }\end{array}$ & $\begin{array}{c}\text { I wasn't aware an } \\
\text { event occurred_ }\end{array}$ & $\begin{array}{c}\text { No, not until } \\
\text { it was over_ }\end{array}$ & $\begin{array}{c}\text { Yes, before the } \\
\text { event took place_ }\end{array}$ & $\begin{array}{c}\text { Yes, during } \\
\text { the event__ }\end{array}$ \\
\hline $\begin{array}{l}2 \text { Deg. } \\
\text { Offset }\end{array}$ & & & & 16 & \\
\hline $\begin{array}{l}4 \text { Deg. } \\
\text { Offset }\end{array}$ & 2 & 4 & & 41 & 1 \\
\hline CPP & 1 & 15 & 1 & 117 & 6 \\
\hline
\end{tabular}

\begin{tabular}{|l|l|l|l|l|l|}
\hline $\begin{array}{l}\text { Business } \\
\text { Type }\end{array}$ & $\begin{array}{l}\text { No } \\
\text { answer }\end{array}$ & $\begin{array}{l}\text { I wasn't aware an } \\
\text { event occurred_ }\end{array}$ & $\begin{array}{l}\text { No, not until } \\
\text { it was over__ }\end{array}$ & $\begin{array}{l}\text { Yes, before the } \\
\text { event took place__ }\end{array}$ & $\begin{array}{l}\text { Yes, during } \\
\text { the event__ }\end{array}$ \\
\hline Office & 2 & 5 & & 92 & 1 \\
\hline Restaurant & & 8 & & 18 & \\
\hline Retail & 1 & 6 & 1 & 64 & 6 \\
\hline
\end{tabular}

\section{What actions did you take?}

\begin{tabular}{|l|r|r|r|r|r|r|r|}
\hline $\begin{array}{l}\text { Program } \\
\text { Choice }\end{array}$ & $\mathrm{n}$ & $\begin{array}{l}\text { Precooled by } \\
\text { Opening } \\
\text { Windows }\end{array}$ & $\begin{array}{c}\text { Precooled using } \\
\text { t-stat precool } \\
\text { option }\end{array}$ & $\begin{array}{c}\text { Used } \\
\text { less } \\
\text { A/C }\end{array}$ & $\begin{array}{l}\text { Used less } \\
\text { lighting }\end{array}$ & $\begin{array}{c}\text { Closed } \\
\text { business } \\
\text { early }\end{array}$ & $\begin{array}{c}\text { N/A } \\
\text { already } \\
\text { closed }\end{array}$ \\
\hline $\begin{array}{l}2 \text { Deg. } \\
\text { Offset }\end{array}$ & 6 & 0 & 1 & 5 & 2 & 1 & 0 \\
\hline $\begin{array}{l}4 \text { Deg. } \\
\text { Offset }\end{array}$ & 19 & 7 & 1 & 17 & 11 & 2 & 2 \\
\hline CPP & 51 & 10 & 13 & 38 & 33 & 14 & 7 \\
\hline
\end{tabular}

\begin{tabular}{|l|l|l|l|l|l|l|l|}
\hline $\begin{array}{l}\text { Business } \\
\text { Type }\end{array}$ & $\mathbf{n}$ & $\begin{array}{c}\text { Precooled by } \\
\text { Opening } \\
\text { Windows }\end{array}$ & $\begin{array}{c}\text { Precooled using } \\
\text { t-stat precool } \\
\text { option }\end{array}$ & $\begin{array}{c}\text { Used } \\
\text { less } \\
\text { A/C }\end{array}$ & $\begin{array}{c}\text { Used less } \\
\text { lighting }\end{array}$ & $\begin{array}{c}\text { Closed } \\
\text { business } \\
\text { early }\end{array}$ & $\begin{array}{c}\text { N/A } \\
\text { already } \\
\text { closed }\end{array}$ \\
\hline Office & 35 & 6 & 7 & 30 & 25 & 10 & 4 \\
\hline Restaurant & 11 & 2 & 0 & 5 & 3 & 0 & 1 \\
\hline Retail & 30 & 9 & 8 & 25 & 18 & 7 & 4 \\
\hline
\end{tabular}

3. What was the comfort level during the event?

\begin{tabular}{|c|c|c|c|c|}
\hline $\begin{array}{c}\text { Program } \\
\text { Choice }\end{array}$ & $\begin{array}{c}\text { No } \\
\text { answer }\end{array}$ & $\begin{array}{c}\text { Comfortable } \\
\text { enough }\end{array}$ & $\begin{array}{c}\text { The event wasn't } \\
\text { noticeable }\end{array}$ & Uncomfortable \\
\hline
\end{tabular}




\begin{tabular}{|c|c|c|c|c|}
\hline $\begin{array}{l}\text { Program } \\
\text { Choice }\end{array}$ & $\begin{array}{c}\text { No } \\
\text { answer }\end{array}$ & $\begin{array}{c}\text { Comfortable } \\
\text { enough }\end{array}$ & $\begin{array}{c}\text { The event wasn't } \\
\text { noticeable }\end{array}$ & Uncomfortable \\
\hline 2 Deg. Offset & & 10 & 5 & 1 \\
\hline 4 Deg. Offset & 4 & 19 & 20 & 5 \\
\hline CPP & 3 & 70 & 51 & 15 \\
\hline
\end{tabular}

\begin{tabular}{|l|l|l|l|l|}
\hline $\begin{array}{l}\text { Business } \\
\text { Type }\end{array}$ & $\begin{array}{l}\text { No } \\
\text { answer }\end{array}$ & $\begin{array}{l}\text { Comfortable } \\
\text { enough__ }\end{array}$ & $\begin{array}{l}\text { The event wasn't } \\
\text { noticeable__ }\end{array}$ & Uncomfortable_- \\
\hline Office & 4 & 47 & 43 & 6 \\
\hline Restaurant & 2 & 3 & 18 & 2 \\
\hline Retail & 1 & 49 & 15 & 13 \\
\hline
\end{tabular}

\section{Were there customer or occupant comments about the event?}

\begin{tabular}{|l|r|r|r|r|}
\hline Program Choice & No answer & No & Yes, negative comments_ & Yes, positive comments \\
\hline 2 Deg. Offset & 15 & & 1 \\
\hline 4 Deg. Offset & 3 & 40 & 5 & 8 \\
\hline CPP & 8 & 113 & 11 & \\
\hline
\end{tabular}

\begin{tabular}{|l|l|l|l|l|}
\hline Business Type & No answer & No & Yes, negative comments__ & Yes, positive comments__ \\
\hline Office & 7 & 84 & 3 & 6 \\
\hline Restaurant & 2 & 23 & & 1 \\
\hline Retail & 2 & 61 & 13 & 2 \\
\hline
\end{tabular}

\section{How was business affected?}

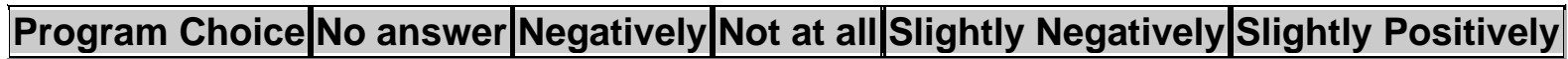

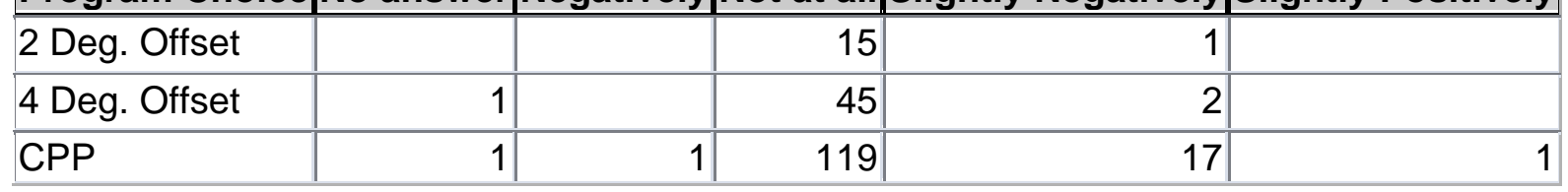

\begin{tabular}{|l|l|l|l|l|l|}
\hline Business Type & No answer & Negatively & Not at all & Slightly Negatively & Slightly Positively \\
\hline Office & 1 & & 92 & 6 & 1 \\
\hline Restaurant & 1 & & 24 & 1 & \\
\hline Retail & & 1 & 63 & 13 & \\
\hline
\end{tabular}




\section{Fall (Post-Experiment) Survey}

\section{General Questions}

1. Excluding the incentive payment, what were your expectations for this program?

\begin{tabular}{|l|r|r|r|r|}
\hline $\begin{array}{l}\text { Program } \\
\text { Choice }\end{array}$ & $\begin{array}{c}\text { I had a high } \\
\text { expectation that it } \\
\text { would benefit me }\end{array}$ & $\begin{array}{c}\text { I had some } \\
\text { expectation that it } \\
\text { might benefit me }\end{array}$ & $\begin{array}{c}\text { I was hopeful, } \\
\text { but not } \\
\text { expecting much }\end{array}$ & $\begin{array}{c}\text { I was not } \\
\text { optimistic that it } \\
\text { would benefit me }\end{array}$ \\
\hline $\begin{array}{l}2 \text { Deg. } \\
\text { Offset }\end{array}$ & 2 & 2 & 2 & 1 \\
\hline $\begin{array}{l}4 \text { Deg. } \\
\text { Offset }\end{array}$ & 5 & 10 & 3 & 2 \\
\hline CPP & 5 & 28 & 15 & \\
\hline
\end{tabular}

\begin{tabular}{|l|l|l|l|l|}
\hline $\begin{array}{l}\text { Business } \\
\text { Type }\end{array}$ & $\begin{array}{l}\text { I had a high } \\
\text { expectation that it } \\
\text { would benefit me }\end{array}$ & $\begin{array}{l}\text { I had some } \\
\text { expectation that it } \\
\text { might benefit me }\end{array}$ & $\begin{array}{l}\text { I was hopeful, } \\
\text { but not } \\
\text { expecting much }\end{array}$ & $\begin{array}{l}\text { I was not } \\
\text { optimistic that it } \\
\text { would benefit me }\end{array}$ \\
\hline Office & 4 & 18 & 10 & 2 \\
\hline Restaurant & 2 & 7 & 2 & \\
\hline Retail & 6 & 15 & 8 & 1 \\
\hline
\end{tabular}

\section{Did the Summer Solutions program meet your expectations?}

\begin{tabular}{|l|r|r|r|r|r|}
\hline Program Choice & No, I'm extremely disappointed & Almost, but not quite & Yes, more or less & It : \\
\hline 2 Deg. Offset & 1 & 3 & 16 \\
\hline 4 Deg. Offset & 1 & 1 & 34 \\
\hline CPP & 3 & 8 & 16 & 34 \\
\hline
\end{tabular}

\begin{tabular}{|l|l|l|l|l|}
\hline $\begin{array}{l}\text { Business } \\
\text { Type }\end{array}$ & $\begin{array}{l}\text { No, I'm extremely } \\
\text { disappointed }\end{array}$ & $\begin{array}{l}\text { Almost, but not } \\
\text { quite }\end{array}$ & $\begin{array}{l}\text { Yes, more } \\
\text { or less }\end{array}$ & $\begin{array}{l}\text { It surpassed my } \\
\text { expectations }\end{array}$ \\
\hline Office & 1 & 4 & 24 & 4 \\
\hline Restaurant & & 1 & 9 & 1 \\
\hline Retail & 3 & 5 & 20 & 2 \\
\hline
\end{tabular}

3. How did your participation in this pilot affect your opinion of SMUD?

\begin{tabular}{|c|l|l|l|l|}
\hline $\begin{array}{c}\text { Program } \\
\text { Choice }\end{array}$ & $\begin{array}{l}\text { My opinion of } \\
\text { SMUD improved } \\
\text { as a result of this } \\
\text { pilot }\end{array}$ & $\begin{array}{l}\text { My opinion of } \\
\text { SMUD was already } \\
\text { negative and did } \\
\text { not change_ }\end{array}$ & $\begin{array}{l}\text { My opinion of } \\
\text { SMUD was already } \\
\text { positive and did } \\
\text { not change }\end{array}$ & $\begin{array}{l}\text { My opinion of } \\
\text { SMUD was made } \\
\text { worse as a result of } \\
\text { this pilot_ }\end{array}$ \\
\hline
\end{tabular}




\begin{tabular}{|l|l|l|l|l|}
\hline $\begin{array}{l}\text { Program } \\
\text { Choice }\end{array}$ & $\begin{array}{l}\text { My opinion of } \\
\text { SMUD improved } \\
\text { as a result of this } \\
\text { pilot }\end{array}$ & $\begin{array}{l}\text { My opinion of } \\
\text { SMUD was already } \\
\text { negative and did } \\
\text { not change_ }\end{array}$ & $\begin{array}{l}\text { My opinion of } \\
\text { SMUD was already } \\
\text { positive and did } \\
\text { not change }\end{array}$ & $\begin{array}{l}\text { My opinion of } \\
\text { SMUD was made } \\
\text { worse as a result of } \\
\text { this pilot__ }\end{array}$ \\
\hline $\begin{array}{l}2 \text { Deg. } \\
\text { Offset }\end{array}$ & 3 & & 3 & 12 \\
\hline $\begin{array}{l}4 \text { Deg. } \\
\text { Offset }\end{array}$ & 7 & & 25 & \\
\hline CPP & 21 & 1 & \\
\hline
\end{tabular}

\begin{tabular}{|l|l|l|l|l|}
\hline $\begin{array}{l}\text { Business } \\
\text { Type }\end{array}$ & $\begin{array}{l}\text { My opinion of } \\
\text { SMUD improved } \\
\text { as a result of this } \\
\text { pilot }\end{array}$ & $\begin{array}{l}\text { My opinion of } \\
\text { SMUD was already } \\
\text { negative and did } \\
\text { not change_ }\end{array}$ & $\begin{array}{l}\text { My opinion of } \\
\text { SMUD was } \\
\text { already positive } \\
\text { and did not change }\end{array}$ & $\begin{array}{l}\text { My opinion of } \\
\text { SMUD was made } \\
\text { worse as a result of } \\
\text { this pilot__ }\end{array}$ \\
\hline Office & 11 & & 23 & \\
\hline Restaurant & 7 & 1 & 3 & \\
\hline Retail & 13 & & 14 & 2 \\
\hline
\end{tabular}

4. What did you like most about the program?

\begin{tabular}{|l|r|l|l|r|}
\hline $\begin{array}{c}\text { Program } \\
\text { Choice }\end{array}$ & $\begin{array}{l}\text { I benefited } \\
\text { financially }\end{array}$ & $\begin{array}{l}\text { I learned to manage my } \\
\text { energy use better_ }\end{array}$ & $\begin{array}{l}\text { I liked the increased } \\
\text { interaction with SMUD_ }\end{array}$ & Nothing \\
\hline $\begin{array}{l}\text { 2 Deg. } \\
\text { Offset }\end{array}$ & 1 & 4 & 1 & \\
\hline $\begin{array}{l}4 \text { Deg. } \\
\text { Offset }\end{array}$ & 4 & 7 & 4 & 4 \\
\hline CPP & 15 & 24 & 5 & 6 \\
\hline
\end{tabular}

\begin{tabular}{|l|l|l|l|l|}
\hline $\begin{array}{l}\text { Business } \\
\text { Type }\end{array}$ & $\begin{array}{l}\text { I benefited } \\
\text { financially }\end{array}$ & $\begin{array}{l}\text { I learned to manage my } \\
\text { energy use better_ }\end{array}$ & $\begin{array}{l}\text { I liked the increased } \\
\text { interaction with SMUD__ }\end{array}$ & Nothing \\
\hline Office & 11 & 15 & 5 & 3 \\
\hline Restaurant & 3 & 5 & 1 & 2 \\
\hline Retail & 6 & 15 & 4 & 5 \\
\hline
\end{tabular}

\section{What did you dislike most about the program?}

\begin{tabular}{|l|l|l|l|r|}
\hline $\begin{array}{c}\text { Program } \\
\text { Choice }\end{array}$ & $\begin{array}{l}\text { I did not benefit } \\
\text { financially_ }\end{array}$ & $\begin{array}{l}\text { I didn't get the attention I } \\
\text { was hoping to get_ }\end{array}$ & $\begin{array}{l}\text { I didn't learn } \\
\text { anything_ }\end{array}$ & Nothing__ \\
\hline 2 Deg. Offset & 1 & 1 & & 4 \\
\hline 4 Deg. Offset & & & & 1 \\
\hline CPP & 8 & 1 & 2 & 16 \\
\hline
\end{tabular}




\begin{tabular}{|l|l|l|l|l|}
\hline $\begin{array}{l}\text { Business } \\
\text { Type }\end{array}$ & $\begin{array}{l}\text { I did not benefit } \\
\text { financially__ }\end{array}$ & $\begin{array}{l}\text { I didn't get the attention I } \\
\text { was hoping to get_ }\end{array}$ & $\begin{array}{l}\text { I didn't learn } \\
\text { anything_ }\end{array}$ & Nothing \\
\hline Office & 3 & & 2 & 28 \\
\hline Restaurant & 2 & 1 & & 8 \\
\hline Retail & 4 & 1 & 1 & 23 \\
\hline
\end{tabular}

\section{Other likes and dislikes:}

\begin{tabular}{|l|l|}
\hline \multicolumn{1}{|c|}{$\begin{array}{c}\text { Program } \\
\text { Choice }\end{array}$} & \multicolumn{1}{c|}{ Other likes and dislikes } \\
\hline 2 Deg. Offset & Interaction with SMUD and its research concepts. \\
\hline 4 Deg. Offset & Also like the financial benefit \\
\hline 4 Deg. Offset & Didn't like the thermostat \\
\hline 4 Deg. Offset & Had difficults at first with several bad thermostats. \\
\hline 4 Deg. Offset & I didn't really change, didn't like the issue with overriding the programming. \\
\hline 4 Deg. Offset & Liked not doing anything, just letting it do its thing \\
\hline 4 Deg. Offset & $\begin{array}{l}\text { Periodic checkups from SMUD confirming everything was working and } \\
\text { functioning correctly }\end{array}$ \\
\hline 4 Deg. Offset & programable thermostats are useful \\
\hline 4 Deg. Offset & $\begin{array}{l}\text { Thermostat did not seem to work properly, second unit was altered, rendered } \\
\text { unusable }\end{array}$ \\
\hline CPP & $\begin{array}{l}\text { Disliked Thermostat - keeps compressor off for 6 minutes - gets too hot during } \\
\text { that time. }\end{array}$ \\
\hline CPP & Great customer service and decent savings. \\
\hline CPP & irregular temp control during pm hrs \\
\hline CPP & Josh was pleasant to work with \\
\hline CPP & LEARNED TO BE MORE CONCIOUS OF ENERGY USE \\
\hline CPP & Like that the program is simple. \\
\hline CPP & Liked helping the community \\
\hline CPP & Liked reducing my energy usage and bill \\
\hline CPP & Liked that it was simple \\
\hline CPP & likes about awareness created in customer \\
\hline CPP & My bill increased. I expected a decrease. \\
\hline CPP & now have a more accurate/reliable meter \\
\hline CPP & Opportunity to learn how to save energy \\
\hline CPP & the critical periods seemed to be on the back to back hottest days \\
\hline CPP & $\begin{array}{l}\text { The people in your program were very responsive and helpful. The financial } \\
\text { gain was extremely minimal }\end{array}$ \\
\hline CPP & Thermostat was not too user friendly \\
\hline CPP & Too much reporting, or surveys \\
\hline
\end{tabular}




\begin{tabular}{|l|c|}
\hline $\begin{array}{c}\text { Program } \\
\text { Choice }\end{array}$ & Other likes and dislikes \\
\hline CPP & Would like more individualized feedback on potential and actual bill savings. \\
\hline
\end{tabular}

\begin{tabular}{|l|l|}
\hline $\begin{array}{l}\text { Business } \\
\text { Type }\end{array}$ & Other likes and dislikes \\
\hline Office & I didn't really change, didn't like the issue with overriding the programming. \\
\hline Office & Liked helping the community \\
\hline Office & Liked reducing my energy usage and bill \\
\hline Office & My bill increased. I expected a decrease. \\
\hline Office & $\begin{array}{l}\text { Periodic checkups from SMUD confirming everything was working and } \\
\text { functioning correctly }\end{array}$ \\
\hline Office & Thermostat was not too user friendly \\
\hline Office & Too much reporting, or surveys \\
\hline Restaurant & Also like the financial benefit \\
\hline Restaurant & Josh was pleasant to work with \\
\hline Restaurant & Like that the program is simple. \\
\hline Restaurant & Would like more individualized feedback on potential and actual bill savings. \\
\hline Retail & Didn't like the thermostat \\
\hline Retail & $\begin{array}{l}\text { Disliked Thermostat - keeps compressor off for } 6 \text { minutes - gets too hot during } \\
\text { that time. }\end{array}$ \\
\hline Retail & Great customer service and decent savings. \\
\hline Retail & Had difficults at first with several bad thermostats. \\
\hline Retail & Interaction with SMUD and its research concepts. \\
\hline Retail & irregular temp control during pm hrs \\
\hline Retail & LEARNED TO BE MORE CONCIOUS OF ENERGY USE \\
\hline Retail & Liked not doing anything, just letting it do its thing \\
\hline Retail & Liked that it was simple \\
\hline Retail & likes about awareness created in customer \\
\hline Retail & now have a more accurate/reliable meter \\
\hline Retail & Opportunity to learn how to save energy \\
\hline Retail & programable thermostats are useful \\
\hline Retail & the critical periods seemed to be on the back to back hottest days \\
\hline Retail & $\begin{array}{l}\text { The people in your program were very responsive and helpful. The financial gain } \\
\text { was extremely minimal }\end{array}$ \\
\hline Retail & $\begin{array}{l}\text { Thermostat did not seem to work properly, second unit was altered, rendered } \\
\text { unusable }\end{array}$ \\
\hline & \\
\hline
\end{tabular}


7. What was your original reason for choosing your program option over the other options?

\begin{tabular}{|l|r|r|r|r|}
\hline $\begin{array}{l}\text { Program } \\
\text { Choice }\end{array}$ & $\begin{array}{c}\text { I had no strong } \\
\text { opinion, so I just } \\
\text { chose the one SMUD } \\
\text { recommended }\end{array}$ & $\begin{array}{c}\text { I like knowing that I } \\
\text { can completely } \\
\text { control my own } \\
\text { responses to }\end{array}$ & $\begin{array}{c}\text { I thought the } \\
\text { program would } \\
\text { give me the } \\
\text { most bill } \\
\text { savings }\end{array}$ & $\begin{array}{c}\text { I'm busy and so I } \\
\text { prefer letting } \\
\text { SMUD control my } \\
\text { response to eve }\end{array}$ \\
\hline $\begin{array}{l}2 \text { Deg. } \\
\text { Offset }\end{array}$ & 4 & 1 & 1 & 1 \\
\hline $\begin{array}{l}4 \text { Deg. } \\
\text { Offset }\end{array}$ & 4 & 9 & 12 & 2 \\
\hline CPP & 8 & & 31 & 1 \\
\hline
\end{tabular}

\begin{tabular}{|l|l|l|l|l|}
\hline $\begin{array}{l}\text { Business } \\
\text { Type }\end{array}$ & $\begin{array}{l}\text { I had no strong } \\
\text { opinion, so I just chose } \\
\text { the one SMUD } \\
\text { recommended }\end{array}$ & $\begin{array}{l}\text { I like knowing that } \\
\text { I can completely } \\
\text { control my own } \\
\text { responses to }\end{array}$ & $\begin{array}{l}\text { I thought the } \\
\text { program would } \\
\text { give me the most } \\
\text { bill savings_ }\end{array}$ & $\begin{array}{l}\text { I'm busy and so I } \\
\text { prefer letting } \\
\text { SMUD control } \\
\text { my response to } \\
\text { eve }\end{array}$ \\
\hline Office & 6 & 7 & 19 & 1 \\
\hline Restaurant & 5 & & 6 & 3 \\
\hline Retail & 5 & 3 & 19 & \\
\hline
\end{tabular}

8. If you were offered the same choices for next summer, how would you choose?

\begin{tabular}{|l|l|r|r|r|}
\hline $\begin{array}{l}\text { Program } \\
\text { Choice }\end{array}$ & $\begin{array}{c}\text { I had no strong } \\
\text { opinion, so I just } \\
\text { chose the one SMUD } \\
\text { recommended }\end{array}$ & $\begin{array}{c}\text { I like knowing that } \\
\text { I can completely } \\
\text { control my own } \\
\text { responses to }\end{array}$ & $\begin{array}{c}\text { I'd choose the } \\
\text { program that } \\
\text { would give me } \\
\text { the most bill } \\
\text { savings_ }\end{array}$ & $\begin{array}{c}\text { I'm busy and so I } \\
\text { prefer letting } \\
\text { SMUD control my } \\
\text { response to eve }\end{array}$ \\
\hline $\begin{array}{l}2 \text { Deg. } \\
\text { Offset }\end{array}$ & 2 & 3 & 1 & 1 \\
\hline $\begin{array}{l}4 \text { Deg. } \\
\text { Offset }\end{array}$ & 4 & 8 & 9 & \\
\hline CPP & 4 & 85 & \\
\hline
\end{tabular}

\begin{tabular}{|l|l|l|l|l|}
\hline $\begin{array}{l}\text { Business } \\
\text { Type }\end{array}$ & $\begin{array}{l}\text { I had no strong } \\
\text { opinion, so I just } \\
\text { chose the one SMUD } \\
\text { recommended }\end{array}$ & $\begin{array}{l}\text { I like knowing that } \\
\text { I can completely } \\
\text { control my own } \\
\text { responses to }\end{array}$ & $\begin{array}{l}\text { I'd choose the } \\
\text { program that } \\
\text { would give me } \\
\text { the most bill } \\
\text { savings_ }\end{array}$ & $\begin{array}{l}\text { I'm busy and so I } \\
\text { prefer letting } \\
\text { SMUD control } \\
\text { my response to } \\
\text { eve }\end{array}$ \\
\hline Office & 2 & 6 & 21 & \\
\hline Restaurant & 3 & 1 & 6 & \\
\hline
\end{tabular}




\begin{tabular}{|l|l|l|l|l|}
\hline $\begin{array}{l}\text { Business } \\
\text { Type }\end{array}$ & $\begin{array}{l}\text { I had no strong } \\
\text { opinion, so I just } \\
\text { chose the one SMUD } \\
\text { recommended }\end{array}$ & $\begin{array}{l}\text { I like knowing that } \\
\text { I can completely } \\
\text { control my own } \\
\text { responses to }\end{array}$ & $\begin{array}{l}\text { I'd choose the } \\
\text { program that } \\
\text { would give me } \\
\text { the most bill } \\
\text { savings_ }\end{array}$ & $\begin{array}{l}\text { I'm busy and so I } \\
\text { prefer letting } \\
\text { SMUD control } \\
\text { my response to } \\
\text { eve }\end{array}$ \\
\hline Retail & 5 & 4 & 18 & 1 \\
\hline
\end{tabular}

\section{Other reasons}

\begin{tabular}{|l|l|}
\hline Program Choice & \multicolumn{1}{|c|}{ Other Reason } \\
\hline 4 Deg. Offset & Free money \\
\hline 4 Deg. Offset & Much better than peak program previously offered as one has more control \\
\hline CPP & I always like to save money one bills \\
\hline CPP & i had old termostate, which was not function accuratly \\
\hline CPP & I want to be responsible regarding energy savings \\
\hline CPP & It was environmentally sound \\
\hline CPP & Want to help our environment with lower the demand. \\
\hline
\end{tabular}

\begin{tabular}{|l|l|}
\hline Business Type & Other Reason \\
\hline Office & I always like to save money one bills \\
\hline Retail & Free money \\
\hline Retail & i had old termostate, which was not function accuratly \\
\hline Retail & I want to be responsible regarding energy savings \\
\hline Retail & It was environmentally sound \\
\hline Retail & Much better than peak program previously offered as one has more control \\
\hline Retail & Want to help our environment with lower the demand. \\
\hline
\end{tabular}

10. How important a factor was the $\$ 120$ incentive payment in your choice to participate in this pilot?

\begin{tabular}{|l|r|r|r|r|}
\hline Program Choice & Very important_Important_Nice, but not critical_Unimportant \\
\hline 2 Deg. Offset & & 3 & 3 & \\
\hline 4 Deg. Offset & 7 & 3 & 7 & 2 \\
\hline CPP & 5 & 10 & 31 & 4 \\
\hline
\end{tabular}

\begin{tabular}{|l|l|l|l|l|}
\hline Business Type & Very important_Important_Nice, but not critical_Unimportant__ \\
\hline Office & 4 & 5 & 21 & 4 \\
\hline Restaurant & 3 & 4 & 3 & 1 \\
\hline Retail & 5 & 7 & 17 & 1 \\
\hline
\end{tabular}


11. Would you participate again next year without the two $\$ 60$ participation payments?

\begin{tabular}{|l|r|r|r|r|}
\hline Program Choice & Definitely not & Probably not_ & Probably__ & Definitely__ \\
\hline 2 Deg. Offset & & 2 & 3 & 1 \\
\hline 4 Deg. Offset & 2 & 3 & 8 & 6 \\
\hline CPP & 4 & 12 & 25 & 9 \\
\hline
\end{tabular}

\begin{tabular}{|l|l|l|l|l|}
\hline Business Type & Definitely not & Probably not__ & Probably_ & Definitely_ \\
\hline Office & & 8 & 18 & 8 \\
\hline Restaurant & & 2 & 5 & 4 \\
\hline Retail & 6 & 7 & 13 & 4 \\
\hline
\end{tabular}

12. When you signed up, how did you think the program would affect your business?

\begin{tabular}{|l|r|r|r|r|r|}
\hline $\begin{array}{c}\text { Program } \\
\text { Choice }\end{array}$ & Negatively_ & $\begin{array}{c}\text { Not at } \\
\text { all }\end{array}$ & Positively_ & $\begin{array}{c}\text { Slightly negatively, if } \\
\text { at all_ }\end{array}$ & $\begin{array}{c}\text { Slightly positively, if } \\
\text { at all__ }\end{array}$ \\
\hline 2 Deg. Offset & 1 & & 3 & 1 & 1 \\
\hline 4 Deg. Offset & & 3 & 5 & 2 & 9 \\
\hline CPP & & 9 & 8 & 10 & 23 \\
\hline
\end{tabular}

\begin{tabular}{|l|l|l|l|l|l|}
\hline $\begin{array}{l}\text { Business } \\
\text { Type }\end{array}$ & Negatively__ & $\begin{array}{l}\text { Not at } \\
\text { all }\end{array}$ & Positively & $\begin{array}{l}\text { Slightly negatively, if } \\
\text { at al__ }\end{array}$ & $\begin{array}{l}\text { Slightly positively, if } \\
\text { at all__ }\end{array}$ \\
\hline Office & & 3 & 7 & 6 & 18 \\
\hline Restaurant & 1 & 4 & 2 & 2 & 2 \\
\hline Retail & & 5 & 7 & 5 & 13 \\
\hline
\end{tabular}

\section{How was business affected by your participation?}

\begin{tabular}{|l|r|r|r|r|r|r|}
\hline $\begin{array}{c}\text { Program } \\
\text { Choice }\end{array}$ & $\begin{array}{c}\text { No } \\
\text { answer }\end{array}$ & Negatively_ & $\begin{array}{l}\text { Not at } \\
\text { all }\end{array}$ & Positively__ & $\begin{array}{l}\text { Slightly negatively, } \\
\text { if at all_ }\end{array}$ & $\begin{array}{l}\text { Slightly positively, } \\
\text { if at all_ }\end{array}$ \\
\hline $\begin{array}{l}\text { 2 Deg. } \\
\text { Offset }\end{array}$ & & & 1 & 2 & 3 \\
\hline $\begin{array}{l}4 \text { Deg. } \\
\text { Offset }\end{array}$ & 1 & & 3 & 5 & 4 & 6 \\
\hline CPP & & 1 & 11 & 5 & 15 & 18 \\
\hline
\end{tabular}

\begin{tabular}{|l|l|l|l|l|l|l|}
\hline $\begin{array}{l}\text { Business } \\
\text { Type }\end{array}$ & $\begin{array}{l}\text { No } \\
\text { answer }\end{array}$ & Negatively__ & $\begin{array}{l}\text { Not at } \\
\text { all }\end{array}$ & Positively__ & $\begin{array}{l}\text { Slightly negatively, } \\
\text { if at al__ }\end{array}$ & $\begin{array}{l}\text { Slightly positively, } \\
\text { if at all__ }\end{array}$ \\
\hline Office & & 3 & 4 & 7 & 20 \\
\hline Restaurant & & 5 & 1 & 2 & 3 \\
\hline Retail & 1 & 1 & 6 & 6 & 12 & 4 \\
\hline
\end{tabular}




\section{Other comments on business effects:}

\begin{tabular}{|l|l|}
\hline $\begin{array}{c}\text { Program } \\
\text { Choice }\end{array}$ & \\
\hline $\begin{array}{l}4 \text { Deg. } \\
\text { Offset }\end{array}$ & always aware of energy use \\
\hline $\begin{array}{l}4 \text { Deg. } \\
\text { Offset }\end{array}$ & Notify email and Tstat. Precooled for 30-45min \\
\hline $\begin{array}{l}4 \text { Deg. } \\
\text { Offset }\end{array}$ & Occasionally the heat would creep up, and having it shut down at 4 was a problem \\
\hline $\begin{array}{l}4 \text { Deg. } \\
\text { Offset }\end{array}$ & $\begin{array}{l}\text { Sometimes a customer would comment about how hot it was in the office, but } \\
\text { realy no other effects. }\end{array}$ \\
\hline $\begin{array}{l}4 \text { Deg. } \\
\text { Offset }\end{array}$ & Wen were not open during the time frame \\
\hline CPP & Don't need any notifications \\
\hline CPP & if you pledge to affect only 12 days, do so. I counted 15 notifications \\
\hline CPP & $\begin{array}{l}\text { It only affected my business on the extreme hot days and we were unable to be } \\
\text { cool. Yet it was manageable. }\end{array}$ \\
\hline CPP & $\begin{array}{l}\text { It was like we did not have any air conditioning at all and had to cancel client's } \\
\text { services many times due to the extreme heat. I believe the probably was with your } \\
\text { thermostat. }\end{array}$ \\
\hline CPP & Josh does a good job \\
\hline CPP & Lights off, customers thought we were closed \\
\hline CPP & other than coustomer it was difficult for us to work \\
\hline CPP & REDUCTION IN SMUD BILL \\
\hline CPP & See answer to No. 6. \\
\hline CPP & There were additional issues with the landlord. \\
\hline
\end{tabular}

\begin{tabular}{|l|l|}
\hline $\begin{array}{l}\text { Business } \\
\text { Type }\end{array}$ & Other_effects \\
\hline Office & Notify email and Tstat. Precooled for 30-45min \\
\hline Office & Occasionally the heat would creep up, and having it shut down at 4 was a problem \\
\hline Office & See answer to No. 6. \\
\hline Office & We were not open during the time frame \\
\hline Restaurant & Don't need any notifications \\
\hline Restaurant & Josh does a good job \\
\hline Restaurant & There were additional issues with the landlord. \\
\hline Retail & always aware of energy use \\
\hline Retail & if you pledge to affect only 12 days, do so. I counted 15 notifications \\
\hline Retail & $\begin{array}{l}\text { It only affected my business on the extreme hot days and we were unable to be } \\
\text { cool. Yet it was manageable. }\end{array}$ \\
\hline Retail & It was like we did not have any air conditioning at all and had to cancel client's \\
\hline
\end{tabular}




\begin{tabular}{|l|l|}
\hline $\begin{array}{l}\text { Business } \\
\text { Type }\end{array}$ & Other_effects \\
\hline & $\begin{array}{l}\text { services many times due to the extreme heat. I believe the probably was with your } \\
\text { thermostat. }\end{array}$ \\
\hline Retail & Lights off, customers thought we were closed \\
\hline Retail & other than coustomer it was difficult for us to work \\
\hline Retail & REDUCTION IN SMUD BILL \\
\hline Retail & $\begin{array}{l}\text { Sometimes a customer would comment about how hot it was in the office, but realy } \\
\text { no other effects. }\end{array}$ \\
\hline
\end{tabular}

15. When you signed up, how difficult did you think it would be to adjust to the events?

\begin{tabular}{|l|r|r|r|r|}
\hline Program Choice & Couldn't do it_lifficult_ & No problem at all & Pretty easy__ \\
\hline 2 Deg. Offset & & & 4 & 2 \\
\hline 4 Deg. Offset & 1 & 1 & 8 & 9 \\
\hline CPP & 1 & 4 & 23 & 21 \\
\hline
\end{tabular}

\begin{tabular}{|l|l|l|l|l|}
\hline Business Type & Couldn't do it__ & Difficult__l & No problem at all & Pretty easy___ \\
\hline Office & 1 & 2 & 12 & 19 \\
\hline Restaurant & & & 7 & 3 \\
\hline Retail & 1 & 3 & 16 & 10 \\
\hline
\end{tabular}

16. How difficult was it for you to adjust to the events?

\begin{tabular}{|l|r|r|r|r|}
\hline Program Choice & Couldn't do it & Difficult & No problem at all & Pretty easy \\
\hline 2 Deg. Offset & & & 4 & 2 \\
\hline 4 Deg. Offset & & & 11 & 8 \\
\hline CPP & 2 & 4 & 25 & 19 \\
\hline
\end{tabular}

\begin{tabular}{|l|l|l|l|l|}
\hline Business Type & Couldn't do it__ & Difficult_ & No problem at all & Pretty easy__ \\
\hline Office & 1 & & 16 & 17 \\
\hline Restaurant & & 8 & 3 \\
\hline Retail & 1 & 4 & 16 & 9 \\
\hline
\end{tabular}

17. If you could choose again, which notification method would you choose?

\begin{tabular}{|l|r|r|r|}
\hline Program Choice & Email & Phone Call|Text_| & Thermostat \\
\hline 2 Deg. Offset & 2 & 2 & 2 \\
\hline
\end{tabular}




\begin{tabular}{|l|r|r|r|r|}
\hline Program Choice & Email & Phone Call & Text__hermostat \\
\hline 4 Deg. Offset & 6 & 1 & 1 & 11 \\
\hline CPP & 26 & 8 & 1 & 14 \\
\hline
\end{tabular}

\begin{tabular}{|l|l|l|l|l|}
\hline Business Type & Email & Phone Call & Text_ & Thermostat \\
\hline Office & 22 & 2 & & 10 \\
\hline Restaurant & 1 & 4 & 1 & 4 \\
\hline Retail & 11 & 5 & 1 & 13 \\
\hline
\end{tabular}

\section{Actions taken as a result of this pilot}

18. I precooled before peak times with air-conditioning

\begin{tabular}{|l|r|r|r|r|}
\hline $\begin{array}{c}\text { Program } \\
\text { Choice }\end{array}$ & $\begin{array}{c}\text { Events } \\
\text { only_ }\end{array}$ & $\begin{array}{c}\text { Every } \\
\text { day_ }\end{array}$ & $\begin{array}{c}\text { Not possible or didn't } \\
\text { try_ }\end{array}$ & $\begin{array}{c}\text { Tried, but it didn't work for } \\
\text { me__ }\end{array}$ \\
\hline 2 Deg. Offset & 1 & 1 & 2 & 2 \\
\hline 4 Deg. Offset & 3 & 4 & 8 & 3 \\
\hline CPP & 9 & 12 & 21 & 5 \\
\hline
\end{tabular}

\begin{tabular}{|l|l|l|l|l|}
\hline $\begin{array}{l}\text { Business } \\
\text { Type }\end{array}$ & $\begin{array}{l}\text { Events } \\
\text { only__ }\end{array}$ & $\begin{array}{l}\text { Every } \\
\text { day_ }\end{array}$ & $\begin{array}{l}\text { Not possible or didn't } \\
\text { try_ }\end{array}$ & $\begin{array}{l}\text { Tried, but it didn't work for } \\
\text { me__ }\end{array}$ \\
\hline Office & 7 & 7 & 12 & 7 \\
\hline Restaurant & 3 & 3 & 2 & 1 \\
\hline Retail & 3 & 7 & 17 & 2 \\
\hline
\end{tabular}

19. I precooled before peak times by running ventilation system or opening windows/doors

\begin{tabular}{|l|r|r|r|r|r|}
\hline $\begin{array}{c}\text { Program } \\
\text { Choice }\end{array}$ & $\begin{array}{c}\text { Events } \\
\text { only_ }\end{array}$ & $\begin{array}{c}\text { Every } \\
\text { day_ }\end{array}$ & $\begin{array}{c}\text { Not Possible or didn't } \\
\text { try }\end{array}$ & $\begin{array}{c}\text { Tried, but it didn't work for } \\
\text { me__ }\end{array}$ \\
\hline 2 Deg. Offset & 1 & & 4 & 1 \\
\hline 4 Deg. Offset & 1 & 8 & 10 & 4 \\
\hline CPP & 4 & 21 & 18 & \\
\hline
\end{tabular}

\begin{tabular}{|l|l|l|l|l|}
\hline $\begin{array}{l}\text { Business } \\
\text { Type }\end{array}$ & $\begin{array}{l}\text { Events } \\
\text { only_ }\end{array}$ & $\begin{array}{l}\text { Every } \\
\text { day_ }_{-}\end{array}$ & $\begin{array}{l}\text { Not Possible or didn't } \\
\text { try }\end{array}$ & $\begin{array}{l}\text { Tried, but it didn't work for } \\
\text { me__ }^{-}\end{array}$ \\
\hline Office & 2 & 13 & 17 & 2 \\
\hline Restaurant & 2 & 3 & 3 & 1 \\
\hline Retail & 2 & 13 & 12 & 2 \\
\hline
\end{tabular}


20. I turned on a floor or desk fan

\begin{tabular}{|l|r|r|r|r|}
\hline $\begin{array}{c}\text { Program } \\
\text { Choice }\end{array}$ & $\begin{array}{c}\text { Events } \\
\text { only }\end{array}$ & $\begin{array}{c}\text { Every } \\
\text { day_ }\end{array}$ & $\begin{array}{c}\text { Not possible or didn't } \\
\text { try_ }\end{array}$ & $\begin{array}{c}\text { Tried, but it didn't work for } \\
\text { me__ }\end{array}$ \\
\hline 2 Deg. Offset & & 3 & 2 & 1 \\
\hline 4 Deg. Offset & 2 & 7 & 10 & \\
\hline CPP & 6 & 24 & 16 & 1 \\
\hline
\end{tabular}

\begin{tabular}{|l|r|r|r|r|}
\hline $\begin{array}{c}\text { Business } \\
\text { Type }\end{array}$ & $\begin{array}{c}\text { Events } \\
\text { only }\end{array}$ & $\begin{array}{c}\text { Every } \\
\text { day__ }\end{array}$ & $\begin{array}{c}\text { Not possible or didn't } \\
\text { try_ }\end{array}$ & $\begin{array}{c}\text { Tried, but it didn't work for } \\
\text { me_ }\end{array}$ \\
\hline Office & 2 & 15 & 17 & \\
\hline Restaurant & 2 & 6 & 1 & \\
\hline Retail & 4 & 13 & 10 & \\
\hline
\end{tabular}

\section{I shaded the windows}

\begin{tabular}{|l|l|l|l|}
\hline Program Choice & Events only_Every day_Not possible or didn't try_ \\
\hline
\end{tabular}

\begin{tabular}{|l|r|r|r|}
\hline 2 Deg. Offset & & 2 & 4 \\
\hline 4 Deg. Offset & 1 & 7 & 11 \\
\hline CPP & 1 & 15 & 30 \\
\hline
\end{tabular}

\begin{tabular}{|l|l|l|l|}
\hline Business Type & Events only_ & Every day__ & Not possible or didn't try__ \\
\hline Office & 2 & 14 & 18 \\
\hline Restaurant & & 4 & 5 \\
\hline Retail & & 6 & 22 \\
\hline
\end{tabular}

22. I turned off some or all of the electric lights

\begin{tabular}{|l|r|r|r|r|}
\hline $\begin{array}{c}\text { Program } \\
\text { Choice }\end{array}$ & $\begin{array}{c}\text { Events } \\
\text { only }\end{array}$ & $\begin{array}{c}\text { Every } \\
\text { day_ }\end{array}$ & $\begin{array}{c}\text { Not Possible or didn't } \\
\text { try }\end{array}$ & $\begin{array}{c}\text { Tried, but it didn't work for } \\
\text { me__ }\end{array}$ \\
\hline 2 Deg. Offset & 1 & 3 & 2 & 1 \\
\hline 4 Deg. Offset & 4 & 9 & 5 & 5 \\
\hline CPP & 10 & 20 & 12 & \\
\hline
\end{tabular}

\begin{tabular}{|l|l|l|l|l|}
\hline $\begin{array}{l}\text { Business } \\
\text { Type }\end{array}$ & $\begin{array}{l}\text { Events } \\
\text { only }\end{array}$ & $\begin{array}{l}\text { Every } \\
\text { day_ }\end{array}$ & $\begin{array}{l}\text { Not Possible or didn't } \\
\text { try }\end{array}$ & $\begin{array}{l}\text { Tried, but it didn't work for } \\
\text { me_ }\end{array}$ \\
\hline Office & 8 & 16 & 8 & 2 \\
\hline Restaurant & 1 & 3 & 3 & 2 \\
\hline Retail & 6 & 13 & 8 & 2 \\
\hline
\end{tabular}


23. I turned off some or all of the equipment

\begin{tabular}{|l|r|r|r|rr|}
\hline $\begin{array}{c}\text { Program } \\
\text { Choice }\end{array}$ & $\begin{array}{c}\text { Events } \\
\text { only }\end{array}$ & $\begin{array}{c}\text { Every } \\
\text { day_ }\end{array}$ & $\begin{array}{c}\text { Not Possible or didn't } \\
\text { try }\end{array}$ & $\begin{array}{c}\text { Tried, but it didn't work for } \\
\text { me__ }\end{array}$ \\
\hline 2 Deg. Offset & 1 & 1 & & 3 & 1 \\
\hline 4 Deg. Offset & 1 & 6 & 12 & \\
\hline CPP & 12 & 11 & 20 & \\
\hline
\end{tabular}

\begin{tabular}{|l|l|l|l|l|}
\hline $\begin{array}{l}\text { Business } \\
\text { Type }\end{array}$ & $\begin{array}{l}\text { Events } \\
\text { only }\end{array}$ & $\begin{array}{l}\text { Every } \\
\text { day__}_{-}\end{array}$ & $\begin{array}{l}\text { Not Possible or didn't } \\
\text { try }\end{array}$ & $\begin{array}{l}\text { Tried, but it didn't work for } \\
\text { me__ }\end{array}$ \\
\hline Office & 7 & 10 & 15 & 1 \\
\hline Restaurant & 1 & 2 & 4 & 2 \\
\hline Retail & 6 & 6 & 16 & 1 \\
\hline
\end{tabular}

24. I let the staff dress more casually

\begin{tabular}{|l|l|r|r|r|r|}
\hline $\begin{array}{c}\text { Program } \\
\text { Choice }\end{array}$ & $\begin{array}{c}\text { Events } \\
\text { only_ }\end{array}$ & $\begin{array}{c}\text { Every } \\
\text { day_ }\end{array}$ & $\begin{array}{c}\text { Not Possible or didn't } \\
\text { try }\end{array}$ & $\begin{array}{c}\text { Tried, but it didn't work for } \\
\text { me__ }\end{array}$ \\
\hline 2 Deg. Offset & & 1 & 4 & 1 \\
\hline 4 Deg. Offset & & 5 & 14 & \\
\hline CPP & & 10 & 29 & 4 \\
\hline
\end{tabular}

\begin{tabular}{|l|r|r|r|r|}
\hline $\begin{array}{c}\text { Business } \\
\text { Type }\end{array}$ & $\begin{array}{c}\text { Events } \\
\text { only_ }\end{array}$ & $\begin{array}{c}\text { Every } \\
\text { day_ }\end{array}$ & $\begin{array}{c}\text { Not Possible or didn't } \\
\text { try }\end{array}$ & $\begin{array}{c}\text { Tried, but it didn't work for } \\
\text { me__ }\end{array}$ \\
\hline Office & 2 & 7 & 23 & 2 \\
\hline Restaurant & & 1 & 7 & 1 \\
\hline Retail & & 8 & 17 & 2 \\
\hline
\end{tabular}

\section{I let some staff go home early}

\begin{tabular}{|l|l|r|r|r|r|}
\hline $\begin{array}{c}\text { Program } \\
\text { Choice }\end{array}$ & $\begin{array}{c}\text { Events } \\
\text { only_ }\end{array}$ & $\begin{array}{c}\text { Every } \\
\text { day__ }\end{array}$ & $\begin{array}{c}\text { Not Possible or didn't } \\
\text { try }\end{array}$ & $\begin{array}{c}\text { Tried, but it didn't work for } \\
\text { me__ }\end{array}$ \\
\hline 2 Deg. Offset & & 1 & 5 & \\
\hline 4 Deg. Offset & & 2 & 15 & \\
\hline CPP & & 8 & 6 & 30 & 1 \\
\hline
\end{tabular}

\begin{tabular}{|l|l|l|l|l|}
\hline $\begin{array}{l}\text { Business } \\
\text { Type }\end{array}$ & $\begin{array}{l}\text { Events } \\
\text { only_ }_{-}\end{array}$ & $\begin{array}{l}\text { Every } \\
\text { day_ }\end{array}$ & $\begin{array}{l}\text { Not Possible or didn't } \\
\text { try }\end{array}$ & $\begin{array}{l}\text { Tried, but it didn't work for } \\
\text { me_ }\end{array}$ \\
\hline
\end{tabular}




\begin{tabular}{|l|l|l|l|l|}
\hline $\begin{array}{l}\text { Business } \\
\text { Type }\end{array}$ & $\begin{array}{l}\text { Events } \\
\text { only__ }\end{array}$ & $\begin{array}{l}\text { Every } \\
\text { day__ }\end{array}$ & $\begin{array}{l}\text { Not Possible or didn't } \\
\text { try }\end{array}$ & $\begin{array}{l}\text { Tried, but it didn't work for } \\
\text { me__ }\end{array}$ \\
\hline Office & 4 & 3 & 25 & 1 \\
\hline Restaurant & & 3 & 6 & \\
\hline Retail & 4 & 3 & 19 & \\
\hline
\end{tabular}

26. I closed the door to the outside during peak hours

\begin{tabular}{|l|r|r|r|}
\hline Program Choice & Every day_Not possible or didn't try_Tried, but it didn't work for me__ & 3 & \\
\hline 2 Deg. Offset & 3 & 7 & \\
\hline 4 Deg. Offset & 12 & 15 & 2 \\
\hline CPP & 28 & & \\
\hline
\end{tabular}

\begin{tabular}{|l|r|r|r|}
\hline Business Type & Every day_Not possible or didn't try_tried, but it didn't work for me__ \\
\hline Office & 20 & 13 & 1 \\
\hline Restaurant & 5 & 4 & 1 \\
\hline Retail & 18 & 8 & \\
\hline
\end{tabular}

\section{Raised AC temperature setpoint}

\begin{tabular}{|l|r|r|r|r|}
\hline $\begin{array}{c}\text { Program } \\
\text { Choice }\end{array}$ & $\begin{array}{c}\text { Events } \\
\text { only }\end{array}$ & $\begin{array}{c}\text { Every } \\
\text { day_ }\end{array}$ & $\begin{array}{c}\text { Not Possible or didn't } \\
\text { try }\end{array}$ & $\begin{array}{c}\text { Tried, but it didn't work for } \\
\text { me__ }\end{array}$ \\
\hline 2 Deg. Offset & & 2 & 4 & \\
\hline 4 Deg. Offset & 6 & 6 & 7 & 6 \\
\hline CPP & 16 & 11 & 14 & \\
\hline
\end{tabular}

\begin{tabular}{|l|l|l|l|l|}
\hline $\begin{array}{l}\text { Business } \\
\text { Type }\end{array}$ & $\begin{array}{l}\text { Events } \\
\text { only }\end{array}$ & $\begin{array}{l}\text { Every } \\
\text { day_ }\end{array}$ & $\begin{array}{l}\text { Not Possible or didn't } \\
\text { try }\end{array}$ & $\begin{array}{l}\text { Tried, but it didn't work for } \\
\text { me__ }^{-}\end{array}$ \\
\hline Office & 10 & 9 & 12 & 3 \\
\hline Restaurant & 4 & 1 & 3 & 1 \\
\hline Retail & 8 & 9 & 10 & 2 \\
\hline
\end{tabular}

\section{Turned AC off}

\begin{tabular}{|l|r|r|r|r|}
\hline $\begin{array}{c}\text { Program } \\
\text { Choice }\end{array}$ & $\begin{array}{c}\text { Events } \\
\text { only_ }\end{array}$ & $\begin{array}{c}\text { Every } \\
\text { day__ }\end{array}$ & $\begin{array}{c}\text { Not Possible or didn't } \\
\text { try }\end{array}$ & $\begin{array}{c}\text { Tried, but it didn't work for } \\
\text { me__ }\end{array}$ \\
\hline 2 Deg. Offset & & 2 & 4 & 1 \\
\hline 4 Deg. Offset & 1 & 2 & 13 & 7 \\
\hline CPP & 6 & 9 & 25 & \\
\hline
\end{tabular}




\begin{tabular}{|l|l|l|l|l|}
\hline $\begin{array}{l}\text { Business } \\
\text { Type }\end{array}$ & $\begin{array}{l}\text { Events } \\
\text { only_ }\end{array}$ & $\begin{array}{l}\text { Every } \\
\text { day_}_{-}\end{array}$ & $\begin{array}{l}\text { Not Possible or didn't } \\
\text { try }\end{array}$ & $\begin{array}{l}\text { Tried, but it didn't work for } \\
\text { me_ }\end{array}$ \\
\hline Office & 4 & 4 & 22 & 1 \\
\hline Restaurant & 1 & 2 & 6 & 1 \\
\hline Retail & 2 & 7 & 14 & 6 \\
\hline
\end{tabular}

\section{Other Actions}

\begin{tabular}{|l|l|}
\hline Program Choice & \multicolumn{1}{|c|}{ OtherDR } \\
\hline 4 Deg. Offset & Always conservative with usage - no real change \\
\hline 4 Deg. Offset & controlled temperatures \\
\hline 4 Deg. Offset & Turned on a fan when it was hot. \\
\hline CPP & ceiling fans \\
\hline CPP & Did not do any laundry (we're a spa) after 3:30 pm \\
\hline CPP & event day were on peak day, it was difficult to try other thing. \\
\hline CPP & Leave at 530 \\
\hline CPP & Left AC on if it was hot \\
\hline CPP & Left early almost everyday (and every event) \\
\hline CPP & my office closes before the events took place \\
\hline CPP & NO A/C \\
\hline CPP & shutdown aircompressor \& Parts cleaner \\
\hline CPP & Turn AC off most of the time, just one when needed \\
\hline CPP & turned off lights on real hot days \\
\hline
\end{tabular}

\begin{tabular}{|l|l|}
\hline Business Type & OtherDR \\
\hline Office & ceiling fans \\
\hline Office & my office closes before the events took place \\
\hline Restaurant & NO A/C \\
\hline Restaurant & turned off lights on real hot days \\
\hline Restaurant & Turned on a fan when it was hot. \\
\hline Retail & Always conservative with usage - no real change \\
\hline Retail & controlled temperatures \\
\hline Retail & Did not do any laundry (we're a spa) after 3:30 pm \\
\hline Retail & event day were on peak day, it was difficult to try other thing. \\
\hline Retail & Leave at 530 \\
\hline Retail & Left AC on if it was hot \\
\hline Retail & Left early almost everyday (and every event) \\
\hline Retail & shutdown aircompressor \& Parts cleaner \\
\hline Retail & Turn AC off most of the time, just one when needed \\
\hline
\end{tabular}


30. What energy efficiency investments did you make as a result of this pilot?

\begin{tabular}{|l|r|r|r|r|}
\hline $\begin{array}{c}\text { Program } \\
\text { Choice }\end{array}$ & $\begin{array}{c}\text { Added window shades or } \\
\text { insulation_ }\end{array}$ & $\begin{array}{c}\text { Improved AC } \\
\text { efficiency_ }\end{array}$ & $\begin{array}{c}\text { Improved lighting } \\
\text { efficiency_ }\end{array}$ & None \\
\hline 2 Deg. Offset & 1 & 1 & 3 & 2 \\
\hline 4 Deg. Offset & 1 & 11 & 3 & 12 \\
\hline CPP & & 1 & 5 & 33 \\
\hline
\end{tabular}

\begin{tabular}{|l|l|l|l|l|}
\hline $\begin{array}{l}\text { Business } \\
\text { Type }\end{array}$ & $\begin{array}{l}\text { Added window shades or } \\
\text { insulation_ }\end{array}$ & $\begin{array}{l}\text { Improved AC } \\
\text { efficiency_ }\end{array}$ & $\begin{array}{l}\text { Improved lighting } \\
\text { efficiency_ }\end{array}$ & None \\
\hline Office & 1 & 6 & 6 & 20 \\
\hline Restaurant & 1 & 2 & 1 & 6 \\
\hline Retail & & 4 & 4 & 21 \\
\hline
\end{tabular}

31. Other Energy Efficiency Investments:

\begin{tabular}{|l|l|l|}
\hline Program Choice & OtherEE & Business Type \\
\hline 4 Deg. Offset & The owner is not receptive to maintenance at all & Office \\
\hline 4 Deg. Offset & Added blinds prior to program & Retail \\
\hline 4 Deg. Offset & Lighting already improved & Retail \\
\hline CPP & Already installed dual-pane windows and new lights & Office \\
\hline CPP & Want to add tinting to the windows. & Restaurant \\
\hline CPP & disconnected eight tube light. & Retail \\
\hline CPP & found illegal taps off of my meter & Retail \\
\hline CPP & got different spot lights, but they do not last or cut costs either & Retail \\
\hline CPP & Improved lighting last year & Retail \\
\hline CPP & New lights prior to program & Retail \\
\hline CPP & Not cost-effective & Retail \\
\hline
\end{tabular}

32. Would you be more likely to make (or encourage your owner to make) energy efficiency improvements if this were a permanent program?

\begin{tabular}{|l|r|r|r|r|}
\hline Program Choice & Definitely not & Definitely_Probably not_Probably__ \\
\hline 2 Deg. Offset & & 1 & 3 & 2 \\
\hline 4 Deg. Offset & 3 & 4 & 4 & 7 \\
\hline CPP & & 8 & 11 & 30 \\
\hline
\end{tabular}




\begin{tabular}{|l|l|l|l|l|}
\hline Business Type & Definitely not & Definitely_ & Probably not__ & Probably__ \\
\hline Office & & 6 & 9 & 17 \\
\hline Restaurant & & 2 & 4 & 5 \\
\hline Retail & 3 & 5 & 5 & 17 \\
\hline
\end{tabular}

\section{Participants with a Summer Solutions Thermostat}

33. How easy or difficult was the Summer Solutions thermostat to work with?

\begin{tabular}{|l|r|r|r|r|}
\hline Program Choice & Couldn't figure it out_ & No problem at all & Pretty difficult & Pretty easy__ \\
\hline 2 Deg. Offset & 2 & & 4 \\
\hline 4 Deg. Offset & 1 & 3 & 4 & 11 \\
\hline CPP & 3 & 9 & 2 & 24 \\
\hline
\end{tabular}

\begin{tabular}{|l|l|l|l|l|}
\hline Business Type & Couldn't figure it out__l & No problem at all & Pretty difficult & Pretty easy__ \\
\hline Office & 3 & 2 & 3 & 20 \\
\hline Restaurant & & 3 & & 5 \\
\hline Retail & 1 & 9 & 3 & 14 \\
\hline
\end{tabular}

34. How does it compare to your old thermostat?

\begin{tabular}{|l|r|r|r|r|}
\hline $\begin{array}{c}\text { Program } \\
\text { Choice }\end{array}$ & $\begin{array}{c}\text { I don't like it_Please } \\
\text { remove it_ }\end{array}$ & $\begin{array}{c}\text { It's about the } \\
\text { same_ }\end{array}$ & $\begin{array}{c}\text { It's harder to use, but } \\
\text { l'll keep it__ }\end{array}$ & $\begin{array}{c}\text { It's much } \\
\text { better_ }\end{array}$ \\
\hline 2 Deg. Offset & & & & 6 \\
\hline 4 Deg. Offset & 1 & 4 & 3 & 11 \\
\hline CPP & 2 & 14 & 7 & 16 \\
\hline
\end{tabular}

\begin{tabular}{|l|l|l|l|l|}
\hline $\begin{array}{l}\text { Business } \\
\text { Type }\end{array}$ & $\begin{array}{l}\text { I don't like it_Please } \\
\text { remove it_ }\end{array}$ & $\begin{array}{l}\text { It's about the } \\
\text { same_ }\end{array}$ & $\begin{array}{l}\text { It's harder to use, but } \\
\text { I'll keep it__ }\end{array}$ & $\begin{array}{l}\text { It's much } \\
\text { better__ }\end{array}$ \\
\hline Office & & 12 & 6 & 11 \\
\hline Restaurant & & & 1 & 7 \\
\hline Retail & 3 & 6 & 3 & 15 \\
\hline
\end{tabular}

35. What changes do you feel should be made to the Summer Solutions thermostat?

\begin{tabular}{|c|c|c|}
\hline $\begin{array}{c}\text { Program } \\
\text { Choice }\end{array}$ & $\begin{array}{c}\text { Business } \\
\text { Type }\end{array}$ & \multicolumn{1}{c|}{ ChangesTstat } \\
\hline 4 Deg. Offset & Office & $\begin{array}{l}\text { A little easier to decipher when changing the temp versus what } \\
\text { temperature it currently is }\end{array}$ \\
\hline
\end{tabular}




\begin{tabular}{|l|l|l|}
\hline $\begin{array}{c}\text { Program } \\
\text { Choice }\end{array}$ & $\begin{array}{c}\text { Business } \\
\text { Type }\end{array}$ & \multicolumn{1}{c|}{ ChangesTstat } \\
\hline 4 Deg. Offset & Office & better operating manual \\
\hline 4 Deg. Offset & Office & control panel made easier to navigate through \\
\hline 4 Deg. Offset & Office & TOO MANY SETTINGS \\
\hline 4 Deg. Offset & Retail & During an event stop the thermostat from flash after an hour or two. \\
\hline 4 Deg. Offset & Retail & It should be simpler to operate \\
\hline CPP & Office & Had to change mine three times \\
\hline CPP & Office & $\begin{array}{l}\text { Having the instruction booklet would make it easier but overall it } \\
\text { was easy to manage }\end{array}$ \\
\hline CPP & Office & Never touched the T-STAT \\
\hline CPP & Restaurant & Need to speak with Staff to answer \\
\hline CPP & Retail & a single sheet easy programming guide would be helpful \\
\hline CPP & Retail & $\begin{array}{l}\text { already removed it as it did not work properly--you saved energy } \\
\text { because it would not allow for air conditioner to work! }\end{array}$ \\
\hline CPP & Retail & it is very good. \\
\hline CPP & Retail & Kill the 6 min. off compressor time. \\
\hline CPP & Retail & Wants the old T-stat back up \\
\hline
\end{tabular}

36. How did you feel about receiving real-time event messages through your thermostat?

\begin{tabular}{|l|r|r|r|r|}
\hline $\begin{array}{c}\text { Program } \\
\text { Choice }\end{array}$ & $\begin{array}{c}\text { I really didn't like } \\
\text { it_ }\end{array}$ & $\begin{array}{c}\text { I really liked } \\
\text { it_ }\end{array}$ & $\begin{array}{c}\text { No strong } \\
\text { feeling_ }\end{array}$ & $\begin{array}{c}\text { Was somewhat } \\
\text { annoyed__ }\end{array}$ \\
\hline 2 Deg. Offset & & 3 & 2 & 1 \\
\hline 4 Deg. Offset & & 14 & 4 & 1 \\
\hline CPP & 3 & 18 & 16 & \\
\hline
\end{tabular}

\begin{tabular}{|l|l|l|l|l|}
\hline $\begin{array}{l}\text { Business } \\
\text { Type }\end{array}$ & $\begin{array}{l}\text { I really didn't like } \\
\text { it_ }\end{array}$ & $\begin{array}{l}\text { I really liked } \\
\text { it_ }\end{array}$ & $\begin{array}{l}\text { No strong } \\
\text { feeling_ }\end{array}$ & $\begin{array}{l}\text { Was somewhat } \\
\text { annoyed_ }\end{array}$ \\
\hline Office & 3 & 17 & 8 & 1 \\
\hline Restaurant & & 4 & 3 & 1 \\
\hline Retail & & 14 & 11 & 2 \\
\hline
\end{tabular}

37. What changes do you feel should be made to the messaging feature?

\begin{tabular}{|l|l|l|}
\hline $\begin{array}{c}\text { Business } \\
\text { Type }\end{array}$ & \multicolumn{1}{|c|}{$\begin{array}{c}\text { Program } \\
\text { Choice }\end{array}$} & \multicolumn{1}{c|}{ ChangesMessages } \\
\hline Office & 4 Deg. Offset & $\begin{array}{l}\text { maybe a soft tone or some sort of noise to indicate that there is } \\
\text { a message }\end{array}$ \\
\hline Office & CPP & None, it was very effective \\
\hline Office & CPP & REALLY LIKED THE NEW BILL \\
\hline
\end{tabular}




\begin{tabular}{|l|l|l|}
\hline $\begin{array}{c}\text { Business } \\
\text { Type }\end{array}$ & $\begin{array}{c}\text { Program } \\
\text { Choice }\end{array}$ & \multicolumn{1}{c|}{ ChangesMessages } \\
\hline Office & CPP & $\begin{array}{l}\text { Thermostat should make a beep that can be cleared after } \\
\text { message is read }\end{array}$ \\
\hline Restaurant & CPP & An audible beep to notify you of events \\
\hline Restaurant & CPP & need to speak with staff \\
\hline Retail & 2 Deg. Offset & Maybe add an alert tone \\
\hline Retail & 4 Deg. Offset & Messages seemed to lock up system. \\
\hline Retail & CPP & Added beep until it was acknowledged. \\
\hline Retail & CPP & it is appropriate \\
\hline Retail & CPP & More detail. \\
\hline Retail & CPP & The message didn't tell the date! \\
\hline
\end{tabular}

38. How did you feel about the thermostat's automatic response to events?

\begin{tabular}{|l|r|r|r|r|}
\hline $\begin{array}{c}\text { Program } \\
\text { Choice }\end{array}$ & $\begin{array}{c}\text { I really didn't like } \\
\text { it_ }\end{array}$ & $\begin{array}{c}\text { I really liked } \\
\text { it_ }\end{array}$ & $\begin{array}{c}\text { No strong } \\
\text { feeling_ }\end{array}$ & $\begin{array}{c}\text { Was somewhat } \\
\text { annoyed__ }\end{array}$ \\
\hline 2 Deg. Offset & 1 & 3 & 2 & \\
\hline 4 Deg. Offset & & 11 & 7 & 1 \\
\hline CPP & 1 & 17 & 18 & 3 \\
\hline
\end{tabular}

\begin{tabular}{|l|l|l|l|l|}
\hline $\begin{array}{l}\text { Business } \\
\text { Type }\end{array}$ & $\begin{array}{l}\text { I really didn't like } \\
\text { it__ }\end{array}$ & $\begin{array}{l}\text { I really liked } \\
\text { it_ }\end{array}$ & $\begin{array}{l}\text { No strong } \\
\text { feeling__ }\end{array}$ & $\begin{array}{l}\text { Was somewhat } \\
\text { annoyed__ }\end{array}$ \\
\hline Office & 1 & 14 & 11 & 3 \\
\hline Restaurant & 1 & 4 & 3 & \\
\hline Retail & & 13 & 13 & 1 \\
\hline
\end{tabular}

\section{What changes do you feel should be made to the automated response feature?}

\begin{tabular}{|l|l|l|}
\hline \multicolumn{1}{|c|}{$\begin{array}{c}\text { Program } \\
\text { Choice }\end{array}$} & \multicolumn{1}{c|}{$\begin{array}{c}\text { Business } \\
\text { Type }\end{array}$} & \multicolumn{1}{c|}{ ChangesAutoResponse } \\
\hline 2 Deg. Offset & Retail & Alert tone to advise the staff of the change. \\
\hline 4 Deg. Offset & Retail & none \\
\hline 4 Deg. Offset & Retail & Was never here at 4pm anyway \\
\hline CPP & Office & Actively managing it manually (turning it off) \\
\hline CPP & Office & I did not have a SMUD thermostat at the office \\
\hline CPP & Office & It worked well for my office \\
\hline CPP & Office & $\begin{array}{l}\text { None or a single beep every 10 minutes until } \\
\text { acknowledged... }\end{array}$ \\
\hline CPP & Office & Sound with it \\
\hline CPP & Restaurant & need to speak to staff \\
\hline
\end{tabular}




\begin{tabular}{|l|l|l|}
\hline $\begin{array}{c}\text { Program } \\
\text { Choice }\end{array}$ & $\begin{array}{c}\text { Business } \\
\text { Type }\end{array}$ & \multicolumn{1}{c|}{ ChangesAutoResponse } \\
\hline CPP & Retail & on a peak day raising temp. by 2 degree is ok \\
\hline
\end{tabular}

40. About how many times did you override the event signal?

\begin{tabular}{|c|c|c|c|c|c|c|c|c|c|c|}
\hline $\begin{array}{c}\text { Program } \\
\text { Choice }\end{array}$ & \begin{tabular}{|l|l|l|} 
& 1
\end{tabular} & $1 \mid 2$ & $\begin{array}{l}3 \text { (actually } \\
\text { bumped it } \\
\text { up) }\end{array}$ & $5|9|$ & \begin{tabular}{c|c}
$a$ \\
few
\end{tabular} & $\begin{array}{c}A \\
\text { lot }\end{array}$ & ALWAYS & $\begin{array}{c}\text { couple } \\
\text { of times }\end{array}$ & $\begin{array}{l}\text { DON'T } \\
\text { KNOW }\end{array}$ & $\begin{array}{l}\text { only when clients } \\
\text { were in on those } \\
\text { days and needed to } \\
\text { get some air--if it } \\
\text { worked at all. }\end{array}$ \\
\hline $\begin{array}{l}2 \text { Deg. } \\
\text { Offset }\end{array}$ & 2 & 1 & & & & & & & 1 & \\
\hline $\begin{array}{l}4 \text { Deg. } \\
\text { Offset }\end{array}$ & 141 & & 1 & & & 1 & & & & \\
\hline CPP & 201 & & & 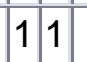 & 3 & 1 & 1 & 1 & & 1 \\
\hline
\end{tabular}

\begin{tabular}{|c|c|c|c|c|c|c|c|c|c|}
\hline $\begin{array}{l}\text { Business } \\
\text { Type }\end{array}$ & \begin{tabular}{l|l|}
0 & 1
\end{tabular} & $2 \mid \begin{array}{l}3 \text { (actually } \\
\text { bumped it } \\
\text { up) }\end{array}$ & 59 & $\begin{array}{l}\text { a } \\
\text { few }\end{array}$ & $\begin{array}{l}\text { A } \\
\text { lot }\end{array}$ & ALWAYS & $\begin{array}{l}\text { couple } \\
\text { of times }\end{array}$ & $\begin{array}{l}\text { DON'T } \\
\text { KNOW }\end{array}$ & $\begin{array}{l}\text { only when clients } \\
\text { were in on those } \\
\text { days and needed to } \\
\text { get some air--if it } \\
\text { worked at all. }\end{array}$ \\
\hline Office & 192 & & & 1 & 2 & & & & \\
\hline Restaurant & 3 & & 1 & 1 & & & & & \\
\hline Retail & 14 & 1 & 1 & 1 & & 1 & 1 & 1 & 1 \\
\hline
\end{tabular}

\section{Participants on the Summer Solutions Rate}

41. How easy or difficult was the Summer Solutions rate to understand?

\begin{tabular}{|l|r|r|r|r|}
\hline Program Choice & Couldn't figure it out_No problem at all_Pretty difficult_ & Pretty easy_ \\
\hline 2 Deg. Offset & 2 & & 2 \\
\hline 4 Deg. Offset & 1 & 3 & 1 & 6 \\
\hline CPP & 6 & 12 & 6 & 20 \\
\hline
\end{tabular}

\begin{tabular}{|l|l|l|l|l|}
\hline Business Type & Couldn't figure it out_No problem at all__l & Pretty difficult__letty easy__ \\
\hline Office & 3 & 9 & 5 & 12 \\
\hline Restaurant & & 3 & 1 & 6 \\
\hline Retail & 4 & 5 & 1 & 10 \\
\hline
\end{tabular}


42. What were your total savings - for the whole summer - on the new rate?

\begin{tabular}{|c|c|c|}
\hline $\begin{array}{l}\text { Program } \\
\text { Choice }\end{array}$ & $\begin{array}{c}\text { Business } \\
\text { Type }\end{array}$ & Savings \\
\hline 2 Deg. Offset & Retail & I think around 5 to 10 a month \\
\hline 2 Deg. Offset & Retail & not sure \\
\hline 4 Deg. Offset & Office & dont know \\
\hline 4 Deg. Offset & Office & don't know \\
\hline 4 Deg. Offset & Office & it looked like my bill was higher, haven't analyzed \\
\hline 4 Deg. Offset & Office & not sure \\
\hline 4 Deg. Offset & Retail & $\$ 30$ \\
\hline 4 Deg. Offset & Retail & don't know \\
\hline CPP & Office & $\$ 150$ \\
\hline CPP & Office & $\$ 32.99$ \\
\hline CPP & Office & $\$ 40$ \\
\hline $\mathrm{CPP}$ & Office & $\$ 400$ \\
\hline CPP & Office & $\$ 5.60$ \\
\hline CPP & Office & couldnt tell besides 120 dollars \\
\hline CPP & Office & didn't pay attention to the bill \\
\hline CPP & Office & $\begin{array}{l}\text { I really don't know how to answer this question since I didn't } \\
\text { have a thermostat }\end{array}$ \\
\hline CPP & Office & I saw some saving \\
\hline CPP & Office & more expensive \\
\hline CPP & Office & not sure \\
\hline CPP & Restaurant & $\$ 100$ \\
\hline CPP & Restaurant & $\$ 200$ \\
\hline CPP & Restaurant & $\$ 30$ \\
\hline CPP & Restaurant & $\$ 35$ \\
\hline CPP & Restaurant & Don't know, just paid whatever it said. \\
\hline CPP & Restaurant & more expensive \\
\hline CPP & Restaurant & unknown--Smud messed up our bills this summer not clear. \\
\hline CPP & Retail & $\$ 100$ \\
\hline CPP & Retail & $\$ 50-\$ 75$ \\
\hline $\mathrm{CPP}$ & Retail & $\$ 50.00$ \\
\hline CPP & Retail & 0 \\
\hline CPP & Retail & $10-15 \%$ \\
\hline CPP & Retail & $10 \%$ \\
\hline CPP & Retail & dont know \\
\hline CPP & Retail & don't know \\
\hline CPP & Retail & more expensive \\
\hline CPP & Retail & more than $50 \%$ \\
\hline $\mathrm{CPP}$ & Retail & Not much if anything! \\
\hline
\end{tabular}




\begin{tabular}{|l|l|l|}
\hline $\begin{array}{c}\text { Program } \\
\text { Choice }\end{array}$ & $\begin{array}{c}\text { Business } \\
\text { Type }\end{array}$ & \multicolumn{1}{c|}{ Savings } \\
\hline CPP & Retail & not very much. I'd say under $\$ 30$ total if that \\
\hline
\end{tabular}

43. Were your savings lower, higher, or about what you expected?

\begin{tabular}{|c|c|c|c|c|}
\hline $\begin{array}{c}\text { Program } \\
\text { Choice }\end{array}$ & $\begin{array}{l}\text { I had no } \\
\text { expectation for } \\
\text { savings }\end{array}$ & $\begin{array}{c}\text { Savings were } \\
\text { about what I } \\
\text { expected } \\
\end{array}$ & \begin{tabular}{|c|} 
Savings were lower \\
than I had \\
expected
\end{tabular} & $\begin{array}{l}\text { Savings were } \\
\text { more than I had } \\
\text { expected }\end{array}$ \\
\hline $\begin{array}{l}2 \text { Deg. } \\
\text { Offset }\end{array}$ & 1 & 1 & 1 & 1 \\
\hline $\begin{array}{l}4 \text { Deg. } \\
\text { Offset }\end{array}$ & 5 & 2 & 4 & \\
\hline CPP & 12 & 12 & 15 & 4 \\
\hline
\end{tabular}

\begin{tabular}{|l|l|l|l|l|}
\hline $\begin{array}{l}\text { Business } \\
\text { Type }\end{array}$ & $\begin{array}{l}\text { I had no } \\
\text { expectation for } \\
\text { savings_ }\end{array}$ & $\begin{array}{l}\text { Savings were } \\
\text { about what I } \\
\text { expected }\end{array}$ & $\begin{array}{l}\text { Savings were lower } \\
\text { than I had } \\
\text { expected_ }\end{array}$ & $\begin{array}{l}\text { Savings were more } \\
\text { than I had } \\
\text { expected }\end{array}$ \\
\hline Office & 11 & 8 & 9 & 1 \\
\hline Restaurant & 3 & 2 & 3 & 2 \\
\hline Retail & 4 & 5 & 8 & 2 \\
\hline
\end{tabular}

44. If you were on this rate permanently, and SMUD did not provide a similar thermostat, would you purchase one yourself to help you respond to events?

\begin{tabular}{|l|l|l|l|l|}
\hline $\begin{array}{l}\text { Program } \\
\text { Choice }\end{array}$ & $\begin{array}{l}\text { Definitely not_I'd } \\
\text { rather do it } \\
\text { manually_ }\end{array}$ & $\begin{array}{l}\text { Definitely_I would save } \\
\text { enough money to cover the } \\
\text { cost_ }\end{array}$ & $\begin{array}{l}\text { Only if it } \\
\text { were less } \\
\text { than } \mathbf{\$ 1 0 0}\end{array}$ & $\begin{array}{l}\text { Only if it } \\
\text { were less } \\
\text { than } \mathbf{\$ 5 0}\end{array}$ \\
\hline $\begin{array}{l}\text { 2 Deg. } \\
\text { Offset }\end{array}$ & 1 & 2 & & 1 \\
\hline $\begin{array}{l}\text { 4 Deg. } \\
\text { Offset }\end{array}$ & 5 & 2 & & 4 \\
\hline CPP & 25 & 7 & 3 & 7 \\
\hline
\end{tabular}

\begin{tabular}{|l|l|l|l|l|}
\hline $\begin{array}{l}\text { Business } \\
\text { Type }\end{array}$ & $\begin{array}{l}\text { Definitely not_I'd } \\
\text { rather do it } \\
\text { manually_ }\end{array}$ & $\begin{array}{l}\text { Definitely_I would save } \\
\text { enough money to cover the } \\
\text { cost_ }\end{array}$ & $\begin{array}{l}\text { Only if it } \\
\text { were less } \\
\text { than } \mathbf{\$ 1 0 0}\end{array}$ & $\begin{array}{l}\text { Only if it } \\
\text { were less } \\
\text { than } \mathbf{\$ 5 0}\end{array}$ \\
\hline Office & 14 & 5 & 3 & 8 \\
\hline Restaurant & 5 & 3 & & 1 \\
\hline Retail & 12 & 3 & & 3 \\
\hline
\end{tabular}


45. Would you be able to install the thermostat yourself?

\begin{tabular}{|c|c|c|c|c|c|c|c|c|c|}
\hline $\begin{array}{l}\text { Program } \\
\text { Choice }\end{array}$ & - & Definitely & $\begin{array}{c}\text { Definitely } \\
\text { not }\end{array}$ & $\begin{array}{c}\text { Definitely } \\
\text { not_ }\end{array}$ & Definitely & Probably & $\begin{array}{c}\text { Probably } \\
\text { not }\end{array}$ & $\begin{array}{c}\text { Probably } \\
\text { not_ }\end{array}$ & Probably_ \\
\hline $\begin{array}{l}2 \text { Deg. } \\
\text { Offset }\end{array}$ & 2 & & & 1 & 1 & & & 2 & \\
\hline $\begin{array}{l}4 \text { Deg. } \\
\text { Offset }\end{array}$ & 5 & & & 2 & 2 & & & 4 & 2 \\
\hline CPP & 3 & 2 & 2 & 5 & 3 & 4 & 3 & 9 & 15 \\
\hline
\end{tabular}

\begin{tabular}{|l|l|l|l|l|l|l|l|l|l|}
\hline $\begin{array}{l}\text { Business } \\
\text { Type }\end{array}$ & - & Definitely & $\begin{array}{l}\text { Definitely } \\
\text { not }\end{array}$ & $\begin{array}{l}\text { Definitely } \\
\text { not_ }\end{array}$ & Definitely__ & Probably & $\begin{array}{l}\text { Probably } \\
\text { not }\end{array}$ & $\begin{array}{l}\text { Probably } \\
\text { not__ }\end{array}$ & Probably_ \\
\hline Office & 3 & 1 & & 4 & 2 & 3 & & 9 & 11 \\
\hline Restaurant & 1 & 1 & 2 & & 1 & & 1 & 4 & \\
\hline Retail & 6 & & 4 & 3 & 1 & 2 & 2 & 6 \\
\hline
\end{tabular}

46. How easy or difficult was the new Summer Solutions bill to understand?

\begin{tabular}{|l|r|r|r|r|}
\hline Program Choice & Couldn't figure it out_No problem at all_Pretty difficult_Pretty easy__ \\
\hline 2 Deg. Offset & & 2 & & 2 \\
\hline 4 Deg. Offset & 2 & 2 & & 7 \\
\hline CPP & 6 & 7 & 6 & 20 \\
\hline
\end{tabular}

\begin{tabular}{|l|l|l|l|l|}
\hline Business Type & Couldn't figure it out_No problem at all__ & Pretty difficult__etty easy__ \\
\hline Office & 4 & 6 & 4 & 15 \\
\hline Restaurant & & 1 & 1 & 6 \\
\hline Retail & 4 & 4 & 1 & 8 \\
\hline
\end{tabular}

